\title{
Data Recovery and Analysis at the Texas State University Ticket Kiosk Project, Located at 41HY160, Spring Lake, Hays County, Texas
}

Jon C. Lohse

Amy E. Reid

Center for Archaeological Studies

David M. Yelacic

Cinda L. Timperley

Center for Archaeological Studies

Follow this and additional works at: https://scholarworks.sfasu.edu/ita

Part of the American Material Culture Commons, Archaeological Anthropology Commons, Environmental Studies Commons, Other American Studies Commons, Other Arts and Humanities Commons, Other History of Art, Architecture, and Archaeology Commons, and the United States History Commons

Tell us how this article helped you.

This Article is brought to you for free and open access by the Center for Regional Heritage Research at SFA ScholarWorks. It has been accepted for inclusion in Index of Texas Archaeology: Open Access Gray Literature from the Lone Star State by an authorized editor of SFA ScholarWorks. For more information, please contact cdsscholarworks@sfasu.edu. 


\section{Data Recovery and Analysis at the Texas State University Ticket Kiosk Project, Located at 41HY160, Spring Lake, Hays County, Texas}

\section{Creative Commons License}

\section{(c) (i) (8)}

This work is licensed under a Creative Commons Attribution-NonCommercial 4.0 International License 


\section{Data Recovery and Analysis at the Texas State University Ticket Kiosk Project, Located at $41 \mathrm{HY} 160$, Spring Lake, Hays County, Texas}

by Jon C. Lohse, Amy E. Reid, David M. Yelacic, and Cinda L. Timperley with contributions by M. Katherine Spradley and Michelle D. Hamilton drawings by Richard L. McReynolds
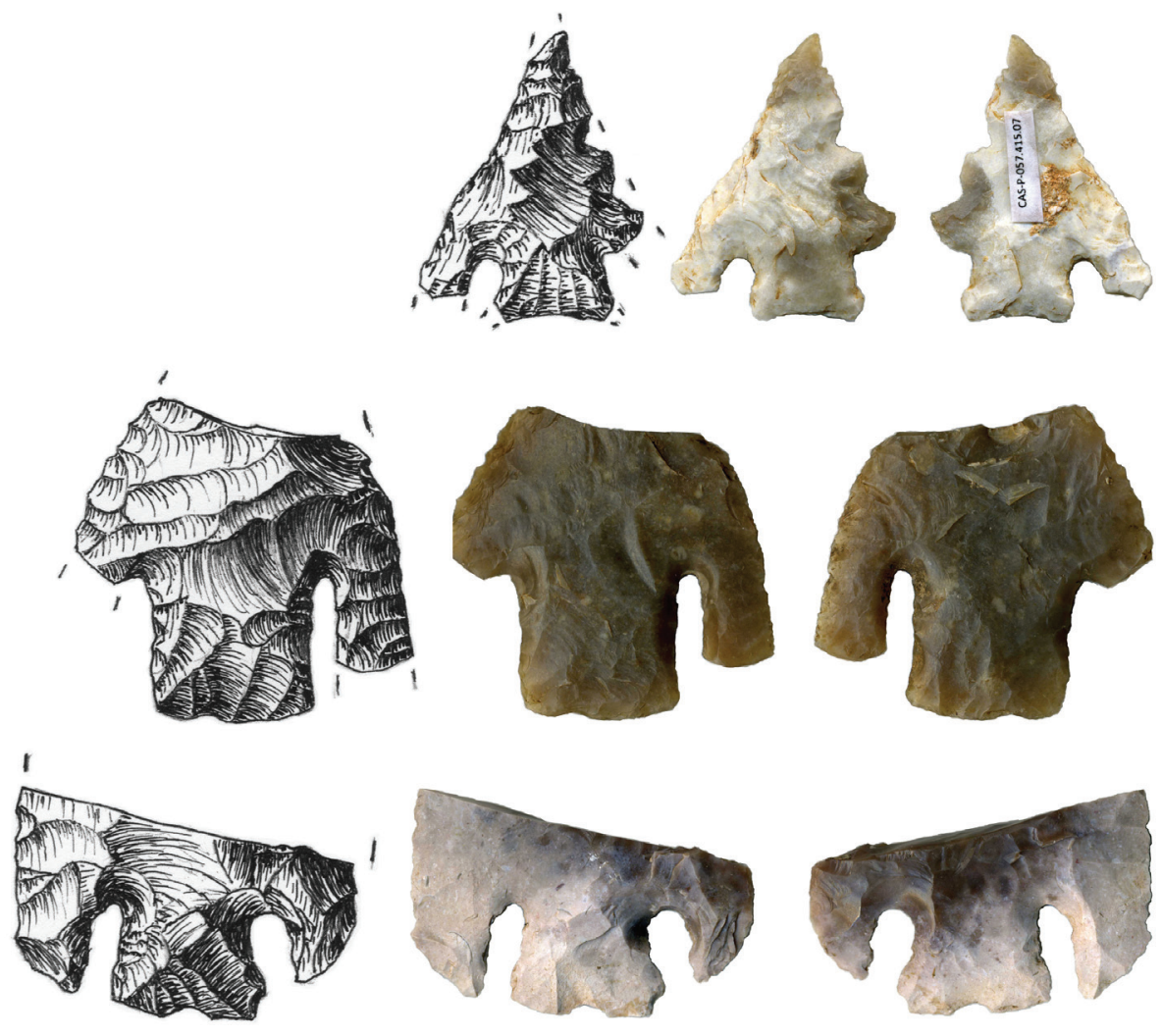

Archaeological Studies Report No. 32

Center for Archaeological Studies

Texas State University-San Marcos 


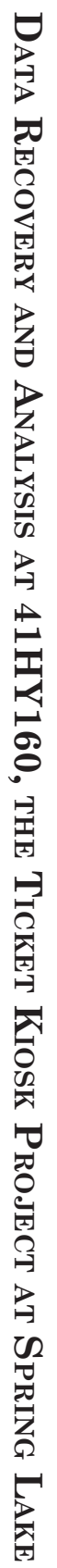

CAS

ASR

32

2013 


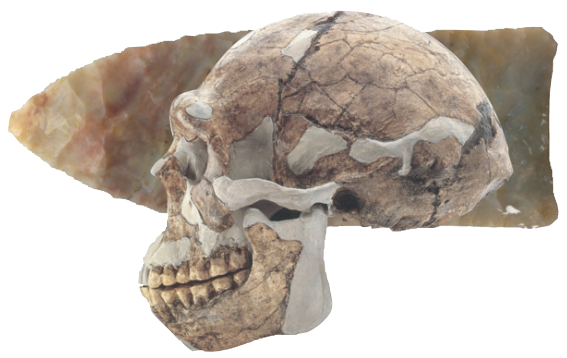

Center for Archaeological Studies

Texas State University-San Marcos

601 University Drive

San Marcos, TX 78666

www.txstate.edu/anthropology/cas/

\section{TEXAS $*$ STATE}

UNIVERSITY

SAN MARCOS

The rising STAR of Texas

A member of The Texas State University System 


\section{Data Recovery and Analysis at the Texas State University Ticket Kiosk Project, Located at 41HY160, Spring Lake, Hays County, Texas}


Report issued in compliance with

Texas Antiquities Permit No. 5938

Jon C. Lohse, Principal Investigator 


\section{Data Recovery and Analysis at the Texas State University Ticket Kiosk Project, Located at 41HY160, Spring Lake, Hays County, Texas}

by Jon C. Lohse, Amy E. Reid, David M. Yelacic, and Cinda L. Timperley with contributions by M. Katherine Spradley and Michelle D. Hamilton drawings by Richard L. McReynolds

Archaeological Studies Report No. 32

Center for Archaeological Studies

Texas State University-San Marcos

August 2013 
The following information is provided in accordance with the General Rules of Practice and Procedures, Title 13, Chapter 26, Texas Administrative Code

1. Type of investigation: Data Recovery and Archaeological Monitoring

2. Project Name: Archaeological Data Recovery Investigations for the Texas State University Ticket Kiosk

3. County: Hays

4. Principal Investigator: Jon C. Lohse

5. Name and location of sponsoring agency: Texas State University, 601 University Drive, San Marcos, TX 78666-4616

6. Published by the Center for Archaeological Studies, Texas State University-San Marcos, 601 University Drive, San Marcos, TX 78666-4616

\title{
Copyright @ 2013 by
}

the Center for Archaeological Studies, Texas State University-San Marcos

\author{
All rights reserved
}

No part of this book may be reproduced or utilized in any form or by any means, electronic or mechanical, including photocopying, recording, or by any information storage and retrieval system without permission in writing.

For further information about this and other publications by the Center for Archaeological Studies, please contact:

Center for Archaeological Studies

Texas State University-San Marcos

601 University Drive

San Marcos, Texas 78666-4616

www.txstate.edu/anthropology/cas

Texas State University-San Marcos is a member of the Texas State University System 


\section{Contents}

List of Figures

List OF TABLES

Management Summary

CHAPTER 1. Introduction

Project Description

Primary Contributions of this report

Calf Creek in Central Texas Context

$\begin{array}{ll}\text { Understanding People Who Occupied Spring Lake } & 7\end{array}$

ChAPTER 2. Environmental and Cultural Context 11

Environmental Context 11

Geology and Soils 12

Weather and Climate $\quad 14$

$\begin{array}{lc}\text { Flora and Fauna } & 18\end{array}$

Cultural Context of Study Area 19

Paleoindian 21

Archaic $\quad 21$

Late Prehistoric $\quad 26$

$\begin{array}{ll}\text { Protohistoric (Spanish Entrada) } & 27\end{array}$

Previous Investigations $\quad 28$

Chapter 3. Data Recovery Objectives and Methods 31

Excavation $\quad 32$

Monitoring 33

Laboratory Methods and Analyses $\quad 35$

CHAPTER 4. Geoarchaeology 37

Sediment Analysis $\quad 37$

Profile Descriptions $\quad 39$

Particle Size and Magnetic Susceptibility $\quad 41$

Chapter 5. Radiocarbon Dates and Dating 43

Presentation of Radiocarbon Results 43

XAD Purification and the Reliability of Bone Dates 44

Problematic Dates $\quad 46$

Discussion of Radiocarbon Results $\quad 47$

CHAPTER 6. Faunal Remains 53

Trends in Faunal Data $\quad 56$

Observations about Recovery Patterns by Animal Size and Type 58

Reptiles, Amphibians, and Birds and their Occurrence 58 
$\begin{array}{ll}\text { Small Mammals and their Occurrence } & 59\end{array}$

Medium Mammals and their Occurrence $\quad 59$

Bison and its Occurrence $\quad 60$

Unidentifiable Bone and its Occurrence $\quad 60$

Discussions of the Faunal Data 60

Chapter 7. Artifacts 63

Lithics $\quad 63$

Projectile Points $\quad 64$

$\begin{array}{lr}\text { Bifaces } & 80\end{array}$

Unifaces and Flake Tools $\quad 87$

Flake Cores $\quad 88$

$\begin{array}{lr}\text { Debitage } & 94\end{array}$

$\begin{array}{lr}\text { Fire-cracked rock } & 96\end{array}$

Modified Bone $\quad 100$

$\begin{array}{ll}\text { Shell Bead } & 100\end{array}$

$\begin{array}{ll}\text { Ceramics } & 101\end{array}$

Chapter 8. Monitoring Activities 105

Sidewall Benching Monitoring 105

$\begin{array}{ll}\text { Auger Monitoring } & 105\end{array}$

Plumbing Trenches 108

Electric Line Trench 109

Waterline Monitoring 110

Water Main Trench Monitoring 111

Irrigation Line Monitoring 112

Walkway and Access Drive Monitoring 114

Burial Documentation, Excavation, and Analysis $\quad 115$

$\begin{array}{ll}\text { Burial Excavation } & 117\end{array}$

$\begin{array}{ll}\text { Cultural Material } & 118\end{array}$

Bioarchaeological Analysis $\quad 120$

Isotopic Analyses $\quad 126$

CHAPTER 9. Conclusions and Recommendations 137

What We Know and Wish We Knew about Calf Creek 138

Summary 144

Appendix A. Projectile Point Metric Data 143

ApPEndix B. Biface data from all excavation units $\quad 147$

ApPENDix C. Biface data from all monitoring and mechanical excavation activities $\quad 149$

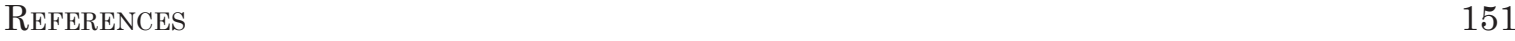




\section{List of Figures}

Figure 1-1 Project area location. 2

Figure 1-2 Floor plan design of the ticket kiosk facility. $\quad 4$

Figure 1-3 Excavations of the relocated Units 3 and 4 underway. 5

Figure 1-4 Calf Creek horizon (Andice) point recovered from 41HY160. 6

Figure 1-5 Calibrated dates associated with Calf Creek deposits from Texas and $\quad 7$ nearby areas.

Figure 2-1 Physiographic map of project area location. 12

Figure 2-2 Cross-section of depositional units in the San Marcos Springs valley. 13

Figure2-3 Age-depth model of radiocarbon dates by depth from an excavation block 15 near the ticket kiosk.

Figure 2-4 Regional environmental models for Central and Coastal Texas. 16

Figure 2-5 Reconstructed mean annual precipitation and mean annual temperature 17 from phytolith data from Hall's Cave, Kerr County, Texas.

Figure 2-6 Record of directly dated bison from in and around Spring Lake site. 18

Figure 2-7 Reconstructed tree cover from pollen records at Boriak and Weakley bogs 19 in greater Central Texas.

Figure 3-1 Overview of project area prior to excavation. 32

Figure 3-2 Units 3 and 4 after the gas line was encountered. 33

Figure 3-3 Cleaning out water-logged lowermost sediments from Units 3 and $4 . \quad 34$

Figure 3-4 Map of areas of controlled units and mechanical excavation that were $\quad 35$ monitored.

Figure 4-1 Technical profile of western wall of Units 3 and $4 . \quad 39$

Figure 4-2 Results of particle size and magnetic susceptibility analysis. 42

Figure 5-1 Results of AMS radiocarbon dates from the ticket kiosk excavation. $\quad 47$

Figure 5-2 Calibrated AMS dates plotted on technical profile of excavation units. $\quad 50$

Figure 6-1 Faunal assemblage from Units 3 and $4 . \quad 57$

Figure 7-1 Early Archaic projectile points, Martindale and Merrell. $\quad 67$

Figure 7-2 Early Archaic projectile points, Uvalde and Gower. 68

Figure 7-3 Early Archaic projectile points, Bell (Calf Creek horizon). 69

Figure 7-4 Middle Archaic projectile points, Almagre/Langtry and Baird. $\quad 70$

$\begin{array}{lll}\text { Figure 7-5 Middle Archaic Nolan projectile points. } & 71\end{array}$

Figure 7-6 Middle Archaic Travis projectile points. $\quad 72$

Figure 7-7 Late Archaic I Bulverde and Pedernales projectile points. 73

Figure 7-8 Examples of Late Archaic I Pedernales projectile points. $\quad 74$

Figure 7-9 Late Archaic I Lange projectile points. $\quad 75$

Figure 7-10 Late Archaic II Castroville projectile points. 76

Figure 7-11 Late Archaic III projectile points, Ensor, Ellis, Edgewood, and Fairland. 77 
Figure 7-12 Transitional Archaic/Austin projectile points, Darl and Scallorn. $\quad 78$

$\begin{array}{lll}\text { Figure 7-13 Late Prehistoric/Toyah arrow points, Perdiz. } & 79\end{array}$

$\begin{array}{lll}\text { Figure 7-14 Untypable dart points. } & 80\end{array}$

Figure 7-15 Untypable dart point fragments. $\quad 81$

Figure 7-16 Untypable arrow point fragment. $\quad 81$

$\begin{array}{lll}\text { Figure 7-17 } & \text { Ovate bifaces. } & 84\end{array}$

$\begin{array}{lll}\text { Figure 7-18 Pointed ovate bifaces. } & 85\end{array}$

Figure 7-19 Lanceolate bifaces. $\quad 86$

Figure 7-20 Examples of distal biface fragments of indeterminate bifaces. 89

Figure 7-21 Examples of medial fragments of indeterminate bifaces. 90

Figure 7-22 Examples of edge fragments of indeterminate bifaces. 91

$\begin{array}{lll}\text { Figure 7-23 } & \text { Flake tools from excavation units } 3 \text { and } 4 . & 92\end{array}$

Figure 7-24 MRUs from excavation units 3 and $4 . \quad 93$

Figure 7-25 Proximal fragments of edge modified pieces that possibly represent the 94 haft element of scrapers that were broken during use.

Figure 7-26 Other lithic tools: Awl, Graver fragment, Multi-edge graver. 95

$\begin{array}{lll}\text { Figure 7-27 Unidirectional core. } & 96\end{array}$

$\begin{array}{lll}\text { Figure 7-28 } & \text { Bidirectional cores. } & 97\end{array}$

$\begin{array}{lll}\text { Figure 7-29 } & \text { Examples of multidirectional flake cores. } & 98\end{array}$

Figure 7-30 Recovery of debitage compared with faunal recovery. $\quad 99$

Figure 7-31 Recovery data for FCR compared with fauna and debitage. 101

Figure 7-32 Bone tools fragments and bead from Units 3 and 4. 102

$\begin{array}{lll}\text { Figure 7-33 Marine columella bead } & 102\end{array}$

$\begin{array}{lll}\text { Figure 7-34 Ceramic fragments. } & 104\end{array}$

Figure 8-1 Mechanical stripping of an area around Units 3 and 4. 106

$\begin{array}{llr}\text { Figure 8-2 Auger excavations. } & 108\end{array}$

$\begin{array}{lll}\text { Figure 8-3 Overview of north building plumbing project. } & 108\end{array}$

Figure 8-4 Formal unifaces fragment recovered during monitoring of trenches for 109 plumbing utilities.

Figure 8-5 CAS archaeologist David Yelacic investigating prehistoric burial. $\quad 110$

Figure 8-6 Close up of a buried fence post with cement base. 111

Figure 8-7 Exploratory trench for main water line. 112

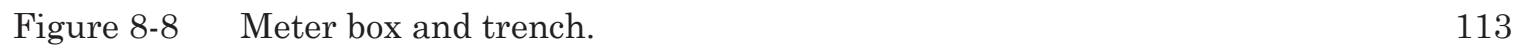

Figure 8-9 Two trenches and one pit for connecting restroom facility with lift $\quad 114$

Figure 8-10 Overview of crescent-shaped access drive. 115

Figure 8-11 THC archaeologist Tiffany Osborne conducting GPR survey of area $\quad 116$

$\begin{array}{ll}\text { Figure 8-12 Excavation unit for burial excavation. } & 117\end{array}$ 
Figure 8-13 Plan view of burial feature and associated artifacts. 119

Figure 8-14 Three projectile points from burial excavation 119

$\begin{array}{lll}\text { Figure 8-15 Dental inventory of burial. } & 124\end{array}$

Figure 8-16 Two-dimensional plot of D2 matrix 128

Figure 8-17 Stable carbon and nitrogen isotope values for six San Marcos burials. 130

Figure 8-18 Prehistoric burial isotope data plotted against protein group regression 132 lines.

Figure 8-19 Average isotopic variation with standard deviations for archaeological 134 bison remains from Spring Lake and nearby sites.

Figure 8-20 Discriminant function temporal values from Central Texas burial data 136 plotted against dietary clusters.

Figure 9-1 Bandy and Merrell points from Spring Lake compared with Calf Creek (Bell) points. 


\section{List of Tables}

Table 2-1 Cultural Chronology for Central Texas 20

Table 2-2 Previously Investigated Sites in the Spring Lake Vicinity 29

Table 5-1 Radiocarbon Assays from Ticket Kiosk Excavation $\quad 51$

Table 6-1 Faunal Remains by Level and Elevation $\quad 54$

Table 7-1 Projectile Points by Elevation $\quad 64$

Table 7-2 Bifaces from Units 3 and $4 \quad 82$

Table 7-3 Flake tools MRUs and Unifaces from Units 3 and $4 \quad 87$

Table 7-4 Flake Cores from Excavation Units 3 and $4 \quad 91$

Table 7-5 Metric and Observed Data for Ceramic Fragments 103

Table 8-1 Cultural Material from Auger Excavations 107

Table 8-2 Cultural Material from Burial Unit 118

Table 8-3 Skeletal Analysis Summary $\quad 120$

Table 8-4 Available Metric Data $\quad 123$

Table 8-5 Native American Comparative Groups for Ancestry Analysis 125

Table 8-6 $\quad$ Isotope Data from Three Sites 129

Table 8-7 Cluster Diets Defined through $k$-means Cluster Analysis 133 


\section{Management Summary}

This report describes the results of data recovery-level archaeological investigations carried out under Texas Antiquities Permit No. 5938 at State Antiquities Landmark 41HY160. The purpose of the project was to offset the impact to cultural deposits at the site stemming from the installation of service utilities for a new restroom facility and ticket kiosk at The Meadows Center for Water and the Environment, (formerly the River Systems Institute) at Texas State University-San Marcos (TxSt). Sponsored by TxSt, the Center for Archaeological Studies excavated a $1 \times 2$ meter unit and monitored construction activities. Resulting cultural materials and other archaeological evidence were analyzed and are discussed in the report.

Excavations exposed and documented a near-continuous occupation sequence spanning the time periods of Late Prehistoric Toyah into the Early Archaic. Cultural deposits were found to extend beyond the lowermost depth of excavations. A series of radiocarbon dates on mammalian bone provide temporal control for this sequence. Of particular importance to the analysis presented here is an intact Calf Creek component, bracketed between Middle Archaic materials and late Early Archaic remains. This component, which dates to approximately $5750-5900$ calibrated years ago, is characterized by the presence of Bell type projectile points and bison remains.

In addition to excavations, archaeological monitoring was also conducted in conjunction with the construction and installation of associated utilities. During the monitoring phase of the project, a single prehistoric human interment was discovered within the planned alignment for electrical utilities. Inasmuch as this part of the project area would become a high-traffic area for the ticket kiosk after project completion, the burial was removed and is a component of the analyses described here. The report evaluates isotope data from the burial remains within a regional context.

Results of the project show that this part of the Spring Lake site is a rich source of archaeological evidence with the potential for addressing numerous significant issues in local and regional Central Texas prehistory. 



\section{Chapter 1 Introduction}

by Jon C. Lohse

In 2011-2012, Texas State University-San Marcos (TxSt) built a new ticket kiosk and restroom facility at The Meadows Center for Water and the Environment (formerly the River Systems Institute), located at Spring Lake, on the TxSt campus. The construction and related utility installations, located within the boundaries of State Archeological Landmark (SAL) 41HY160 (Figure 1-1), were carried out entirely on TxSt property and used University funds. The facility replaces the former visitor center at Aquarena Springs, which was demolished during the comprehensive Spring Lake Aquatic Ecosystem Restoration Project (SLAERP), a Section 206 undertaking that was cosponsored by the United States Army Corps of Engineers and TxSt. The new ticket kiosk is located immediately adjacent to but outside the SLAERP project area.

Considering the source of funds for this construction and its location on TxSt property, TxSt was required to comply with provisions of the Antiquities Code of Texas, which requires that such undertakings be coordinated with the Texas Historical Commission (THC) and to evaluate possible impact of the project on important archaeological resources. In addition to its registry listing as an SAL, 41HY160 has been determined to be eligible for listing to the National Register of Historic Places (NRHP) and is therefore considered highly significant for the information it contains regarding historic and prehistoric events in Texas. Working with the Office of Facilities Planning Design and Construction (OFPDC) at TxSt, the Center for Archaeological Studies (CAS) designed and carried out a plan for data recovery and archaeological monitoring in order to recover information representative of the archaeological record in the immediate area so as to offset the loss of additional information stemming from the construction of the ticket kiosk.

Excavations consisted of a single $1 \times 2 \mathrm{~m}$ unit excavated to a depth of $3.0 \mathrm{~m}$ below the current ground level. Monitoring was conducted based on the planned locations of utilities installation. All excavations and monitoring were carried out under Texas Antiquities Permit No. 5938 (Jon C. Lohse, Principal Investigator). Excavations were conducted in the fall and 


\section{Chapter 1}
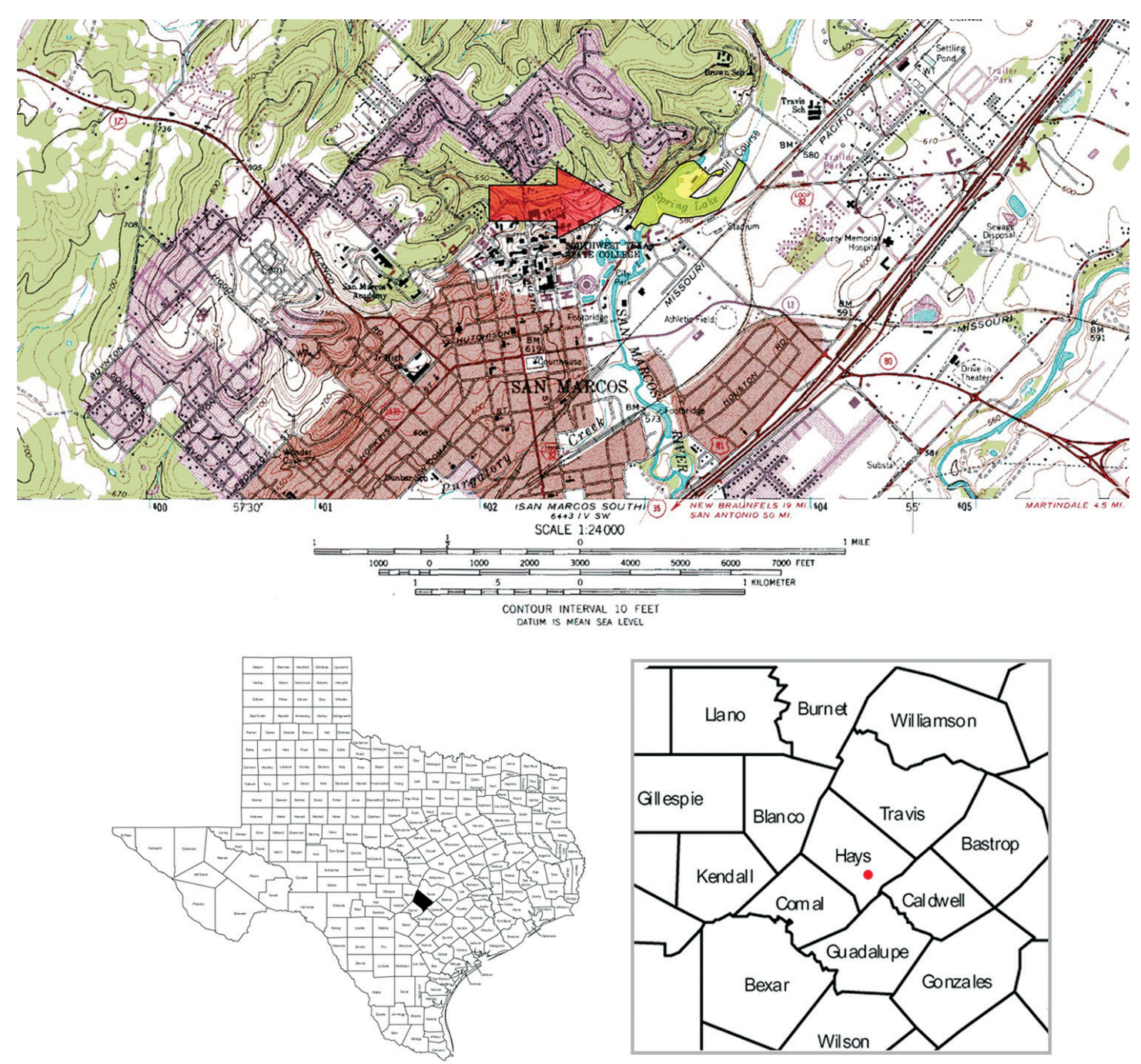

Figure 1-1. Project area location. Yellow polygon indicated by red arrow, on 7.5" United States Geological Survey topographic map; San Marcos North and South sheets.

winter of 2011, and monitoring activities continued into the late spring of 2012. This report presents the methods and findings of those investigations.

The report is organized into several chapters. Chapter 1 describes the undertaking, introduces the investigations, and contextualizes the main contributions of this report to local, regional, and statewide prehistory. Chapter 2 presents the environmental and cultural context of Spring Lake. Archaeological understanding of this important site has grown steadily since initial excavations in the $1970 \mathrm{~s}$, but has rapidly increased in recent years as a result of compliance-driven investigations (Lohse 2013a; Nickels and Bousman 2010; Oksanen 2011), especially the SLAERP (Leezer et al. 2011; Lohse 2013b). The current basis for how we 
understand prehistoric cultural and environmental processes, including regional chronologies and previous work, is summarized in order to contextualize these investigations. Chapter 3 discusses the methods used for excavation and monitoring activities and briefly helps readers understand the approaches taken to addressing key, highly dynamic field conditions over the course of the project. Chapters $4-8$ present the results of the fieldwork. Geoarchaeology at the site is discussed in Chapter 4. Chapter 5 discusses dates and dating. Chapter 6 describes recovered faunal remains and their analysis. Chapter 7 considers artifacts recovered during the project, and Chapter 8 explains the results of the monitoring phase of the project, including data from the discovery of a prehistoric human burial and a summarization of other finds from the monitoring work. It should be noted in general that monitoring is a poor way to record archaeological data; by the time field technicians observe in situ deposits, they will almost certainly have been disturbed by construction or other mechanical activities. Nonetheless, the monitoring efforts in conjunction with this project were sufficient to demonstrate that intact archaeological deposits surround the entire project area, beginning almost immediately at the base of the paved parking and driving surfaces of the Spring Lake area. Moreover, it was through careful monitoring that the burial feature was recognized and exposed before any serious damage was incurred. The final chapter, Chapter 9, presents the overall conclusions of this investigation and provides an update of the understanding of prehistoric human occupation at Spring Lake.

\section{Project Description}

According to TxSt plans, the ticket kiosk was designed as a two-part structure with an open-air walkway between the two buildings. The construction was designed to take place on a pad of fill dirt that was brought in specifically to minimize impacts to archaeological resources. Initially, all impacts were to result from the installation of a lift station to a depth of approximately $8 \mathrm{ft}$ to provide head pressure to the restroom facilities and from the installation of utility service to bring water and electricity to the building (Figure 1-2). Following a geotechnical assessment of the project area, however, planners determined the need for deep piers $(n=36)$ to be driven into the ground to a depth of more than $20 \mathrm{ft}$ to anchor the structure in place.

In response to these impacts, CAS submitted a proposal to the OFPDC and the THC to perform controlled hand excavation of a $1 \times 2 \mathrm{~m}$ unit in the location of the lift station to a depth of $3 \mathrm{~m}$. The size of the unit would be approximately one-half the overall size of the lift station, and would be sufficient to recover enough information so as to satisfactorily mitigate the overall impact from this construction. Additionally, all ground-disturbing utility work would be monitored by on-site archaeologists.

The initial excavation unit was laid out as a $1 \times 2 \mathrm{~m}$ block, under the assumption that all existing utilities had been marked and that none would be encountered. At approximately 60 $\mathrm{cm}$ below surface, however, an active gas line was encountered running diagonally through one 


\section{Chapter 1}

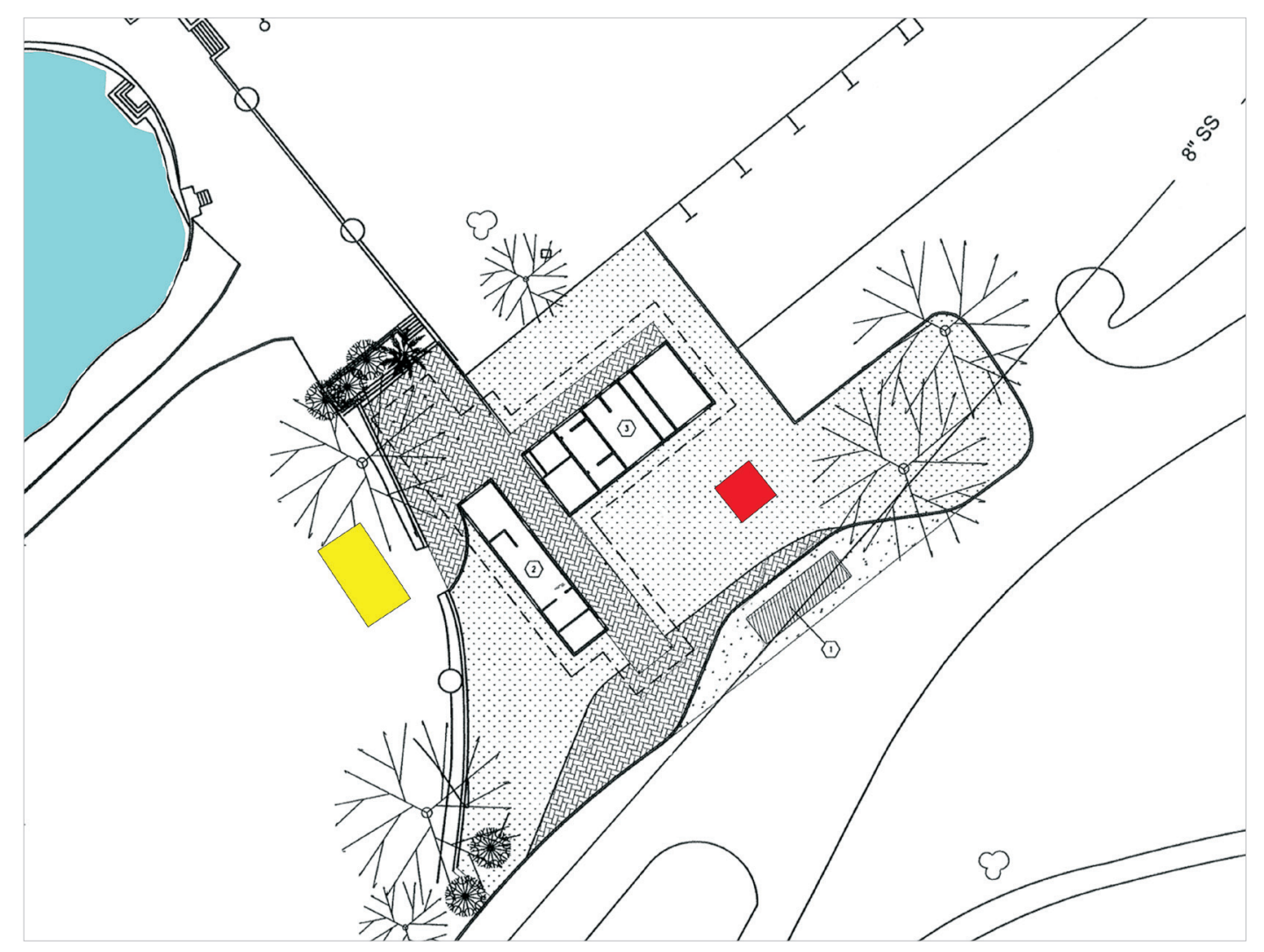

Figure 1-2. Floor plan design of the new ticket kiosk facility near the upper end of Spring Lake. The location of the lift station is marked in red, and the 3x4 m excavation block conducted by field schools in 2001-2006 is in yellow. This block is discussed in more detail in Chapter 2.

of the $1 \mathrm{~m}$ squares and partially through the other (designated as Units 1 and 2). In response, the excavation was relocated $1 \mathrm{~m}$ to the west and $1 \mathrm{~m}$ to the north (Figure 1-3). Units 1 and 2, disturbed by this earlier gas line installation, are not discussed in detail in this report.

\section{Primary Contributions of this Report}

Excavations documented the record of continuous or almost continuous prehistoric occupation at Spring Lake from the end of the Late Prehistoric period, called Toyah in the regional cultural chronology, well into the Early Archaic. Of particular importance in this sequence is what appears to be an intact terminal Early Archaic Calf Creek component, just less than 6000 years old, that was first recognized in 2001-2006 excavations conducted nearby (see Figure 1-2 and discussion in Chapter 2) but never completely sampled until the present project. Considering the continuous nature of deposits here, emphasis is placed on generating a robust record of radiocarbon dates for certain key intervals and components (see Chapter 5). In addition to securely placing Calf Creek in the regional chronological sequence, monitoring efforts resulted in the discovery, documentation, and removal of a single human burial. This 


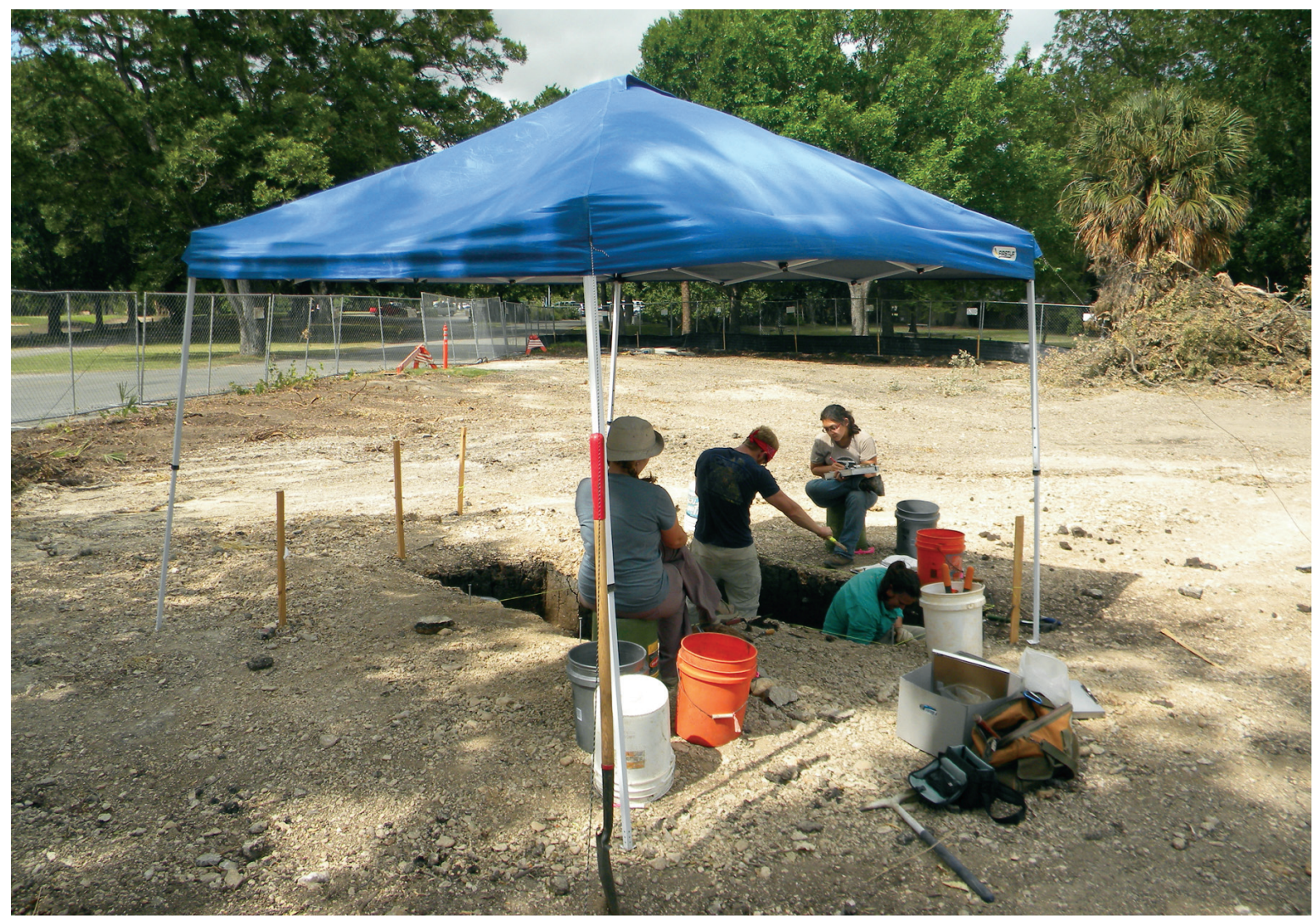

Figure 1-3. Excavations of the relocated Units 3 and 4 underway. Units 1 and 2 are visible at left of seated figure. The chain link fence surrounding this work site marks the project area boundaries of the SLAERP.

interment represents the third human burial to have been recovered from the TxSt campus, and is the seventh individual recovered by CAS from the general San Marcos area. Descriptive analysis and radiometric data from this individual are presented in Chapter 5.

\section{Calf Creek in Central Texas Context}

What Don Wyckoff $(1994,1995)$ has called the Calf Creek Horizon is noteworthy for its close association with Middle Holocene bison exploitation. Named for the Calf Creek shelter in Arkansas (Dickson 1970), this widespread series of cultural traits has been identified across the Southern Great Plains and adjoining areas of Kansas, Missouri, Arkansas, Oklahoma, and Texas. Typologically, dart points found in Texas that comprise the Calf Creek style include Bell, defined at the Landslide site in the Stillhouse Hollow Reservoir (Sorrow et al. 1967) and Andice, defined from specimens from the Gault site (Prewitt 1983). Both types fall into the range of variation associated with Calf Creek points elsewhere and are characterized by triangular bodies with deep basal notches that result in long barbs and typical squared stems (Figure 1-4). 


\section{Chapter 1}

Direct evidence for the use of Calf Creek points in hunting bison has been reported from Oklahoma (Bement et al. 2005), where a juvenile bison skull was uncovered in a stream bed with a Calf Creek point embedded in the base of one of the horns. Bison remains are commonly reported from multicomponent sites where Calf Creek material is also present. Because of unfavorable climatic conditions for this time period, Calf Creek material from greater Central Texas has proven difficult to date precisely. As a result of sediment loss and mixing, components from this period are often found with earlier and/or later remains. For example, the compilation of dates reported from Texas and nearby regions described as associated with Calf Creek (Figure 1-5) produces an untenably wide distribution. The outside span of time covers more than 2,000 years while even a conservative reading of these data approaches 700 years in duration. This interval is presently used to define the end of the Early Archaic; the Middle Archaic period in regional chronologies begins immediately following Calf Creek (Lohse 2013a).

Precisely dating this cultural adaptation and understanding environmental and other associated behavioral changes, would contribute significantly to the understanding of regional and local prehistoric sequences. Presently, archaeologists do not clearly understand the technological and typological antecedents to Calf Creek styles in the region, nor do they understand very well what additional styles might also be associated with this horizon. In addition, models are not available to explain shifts that might have occurred with respect to hunting and prey-choice behaviors during this period of bison presence. If the Calf Creek horizon represents cultural influences from outside the Central Texas region, nonlocal styles might be expected to appear suddenly and without precedent in local assemblages. Answering these and other related questions first requires a considerably more precise understanding of the timing of this event than any currently available data can provide.
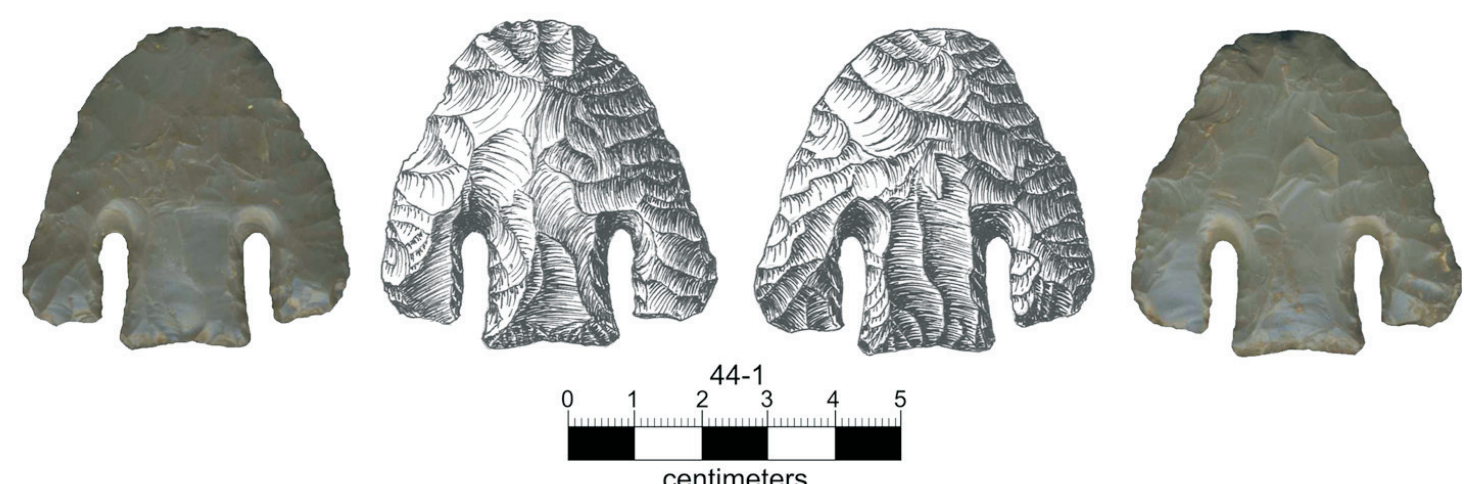

centimeters

Figure 1-4. Calf Creek horizon (Andice) point recovered from 41HY160, immediately adjacent to the Ticket Kiosk excavation. 


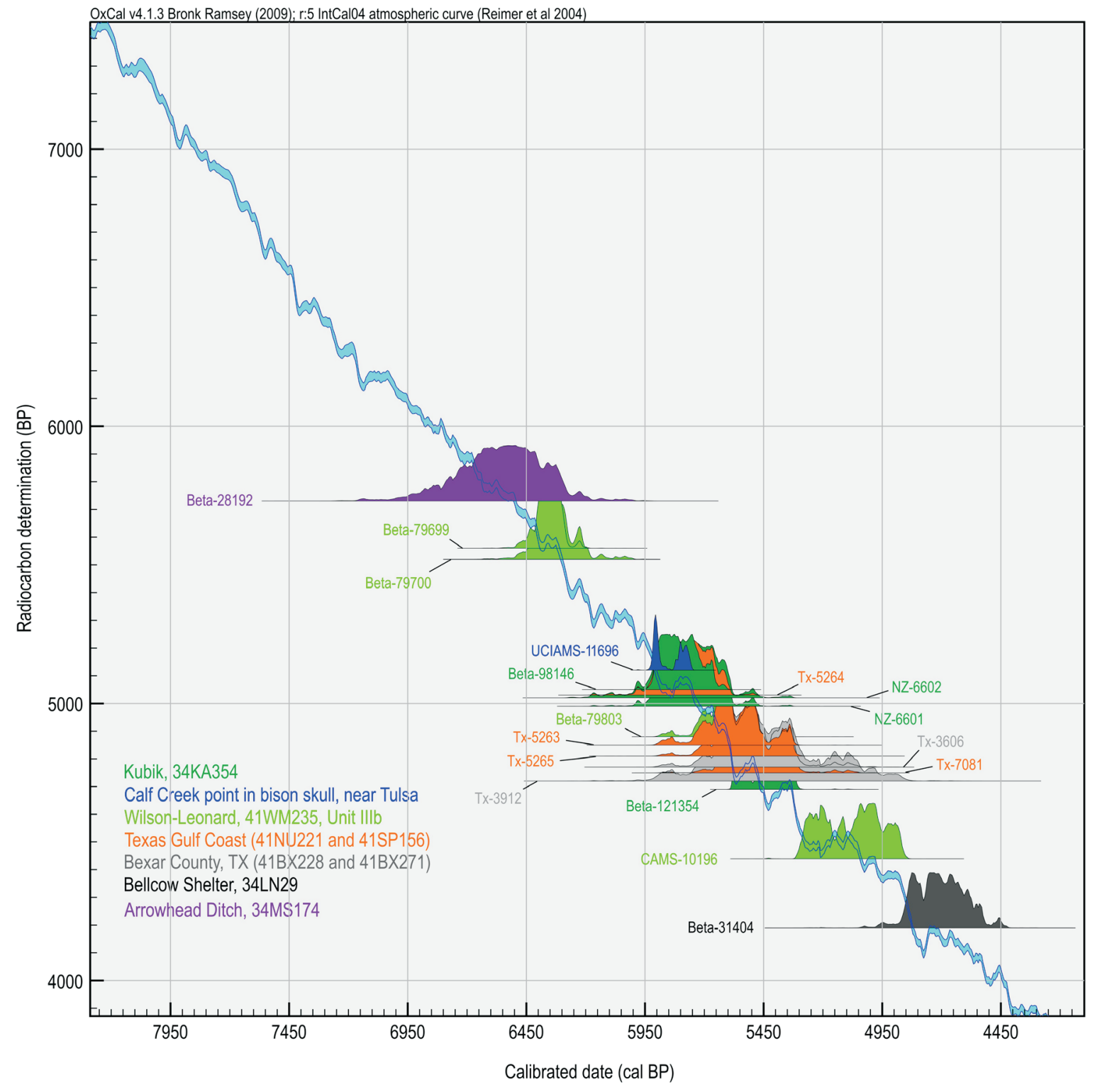

Figure 1-5. Some calibrated dates reportedly associated with Calf Creek deposits from Texas and nearby areas. The extreme span of these dates covers more than 2,000 years, and even the central cluster covers approximately 700 years.

\section{Understanding People Who Occupied Spring Lake}

In addition to the opportunity to date for the first time an intact Calf Creek component, investigations at the Ticket Kiosk recovered an intact prehistoric human interment. To date, only three sets of human remains have been recovered from the TxSt campus, and the overall record of burials from San Marcos includes only four complete individuals (including the one discussed in this report) and three fragmentary ones. Essentially, very little is known 


\section{Chapter 1}

physically about the people who inhabited this area in the past. While the addition of one more individual does not begin to fill this void, this set of remains does add important information about the kinds of people who inhabited this site for more than 13,000 years.

An important aspect of the current project involves plans for the ultimate disposition of these remains, along with others presently under the curatorship of CAS. Prior to the removal of these remains, TxSt was obligated to comply with the Texas Health and Safety Code, which requires either a signed permit to disinter remains from the State Registrar's Office or a signed order from the district court before the remains can be removed. After discussing the project design and circumstances with the OFPDC, CAS recommended that the remains be removed, inasmuch as their former location would be in an area of high traffic and was considered inappropriate for the location of a cemetery (under the Health and Safety Code, even a single interment is defined as a cemetery). Once the remains are removed, however, TxSt and CAS are required to comply with the Native American Graves Protection and Repatriation Act (NAGPRA) in order to determine cultural affiliation and, ultimately, negotiate or find arrangements for the final disposition of the remains. Under NAGPRA, CAS qualifies as a museum, and is obligated to consult with federally recognized tribes and other potentially interested parties, including Native American groups who may have a historical interest in the area but who are not federally recognized, in order to determine the cultural affiliation of these remains. The University's NAGPRA obligations are only triggered when burials are removed and officially taken into possession; if exposed but left in place, no such consultation requirements exist.

When NAGPRA was passed into law in 1990, it addressed some long-standing concerns among Native Americans and others about how the scientific and/or scholarly (archaeological) community had historically treated and controlled Native American human remains (Trope and Echo-Hawk 2000). NAGPRA deals with the disposition of human remains, objects of cultural patrimony, and sacred cultural objects. Importantly, it provides an avenue for Native Americans to participate in decisions about how such objects (and the remains of people) are dealt with and, in some cases, the location to which they are returned. As such, NAGPRA is part property law, part civil rights law, and part Native American law, and it is fundamentally concerned with helping to rectify the longstanding omission of American Indians from discussions of the disposition of their cultural heritage. Along the way, the views held by some archaeologists about the privileged place of science and research relative to the concerns of indigenous groups have come under scrutiny. Many outcomes reached under NAGPRA reflect some manner of compromise between scientific research and the cultural and humanistic concerns of indigenous peoples regarding a shared cultural heritage that is commonly the subject of archaeological research (Goldstein and Kintigh 2000).

In addition to an opportunity to understand Calf Creek more clearly in a regional context, this investigation presents an opportunity to consider how TxSt and CAS will or should approach the study of recovered human remains from the Spring Lake area. Clearly, 
certain minimal data should be recorded in order for scholars and others to make informed assessments concerning cultural affiliation, needed for ultimate disposition of the remains under state and federal law. These minimal data can easily be augmented through additional kinds of analyses in order to recover all possible information about the people (or this person) who inhabited the Spring Lake area during prehistoric times. In the future, technological advances may make it possible to learn more from these remains than is possible today, a possibility that may serve as scientific justification for housing such remains for years. 



\section{Chapter 2 Environmental and Cultural Context}

by Jon C. Lohse and David M. Yelacic

A description of the environmental and cultural contexts of the study area is important in order to characterize and understand the issues that define archaeology and human occupation at Spring Lake. In addition to describing the environmental and cultural contexts of the project area, this chapter also summerizes previous investigations in and around the immediate vicinity of the Ticket Kiosk area.

\section{Environmental Context}

The Spring Lake project area $\left(29^{\circ} 53^{\prime} 38.17^{\prime \prime}\right.$ N, $\left.97^{\circ} 55^{\prime} 45.54^{\prime \prime} \mathrm{W}\right)$ is located within the City of San Marcos in south central Hays County, Texas. This location is centrally located in the Austin-San Antonio Corridor, one of the fastest growing areas in the nation (Quintero 2007). Spring Lake is situated along the base of the Balcones Escarpment in eastern central Texas. The Balcones Escarpment is a prominent physiographic feature created where Cretaceous limestone was uplifted (west) and downthrust (east) along a normal fault until the Eocene (Sellards et al. 1932). This rich and diverse environment contains biological aspects of the Hill Country to the west and Blackland Prairie to the east (Figure 2-1). Transitional environments such as this are referred to as ecotones and have the capacity to support tremendous biodiversity and species richness (Crumley 1994).

Reconstructing paleoenvironmental conditions, often by modeling past climatic as well as floral and faunal variables, is an important means of understanding prehistoric human adaptations. As ancient conditions cannot be directly observed, paleoenvironmental reconstructions rely on proxy measures, which include but are not limited to stable isotopes, phytoliths, fossil pollens, faunal remains, and sediment properties. Paleoenvironmental proxies do not directly reflect past environments, but can be used to infer characteristics of those conditions in which they formed (Ellis et al. 1995). There is much variety in the response of these proxies to their environments and additional variety in the resolution (i.e., accuracy) at 


\section{Chapter 2}

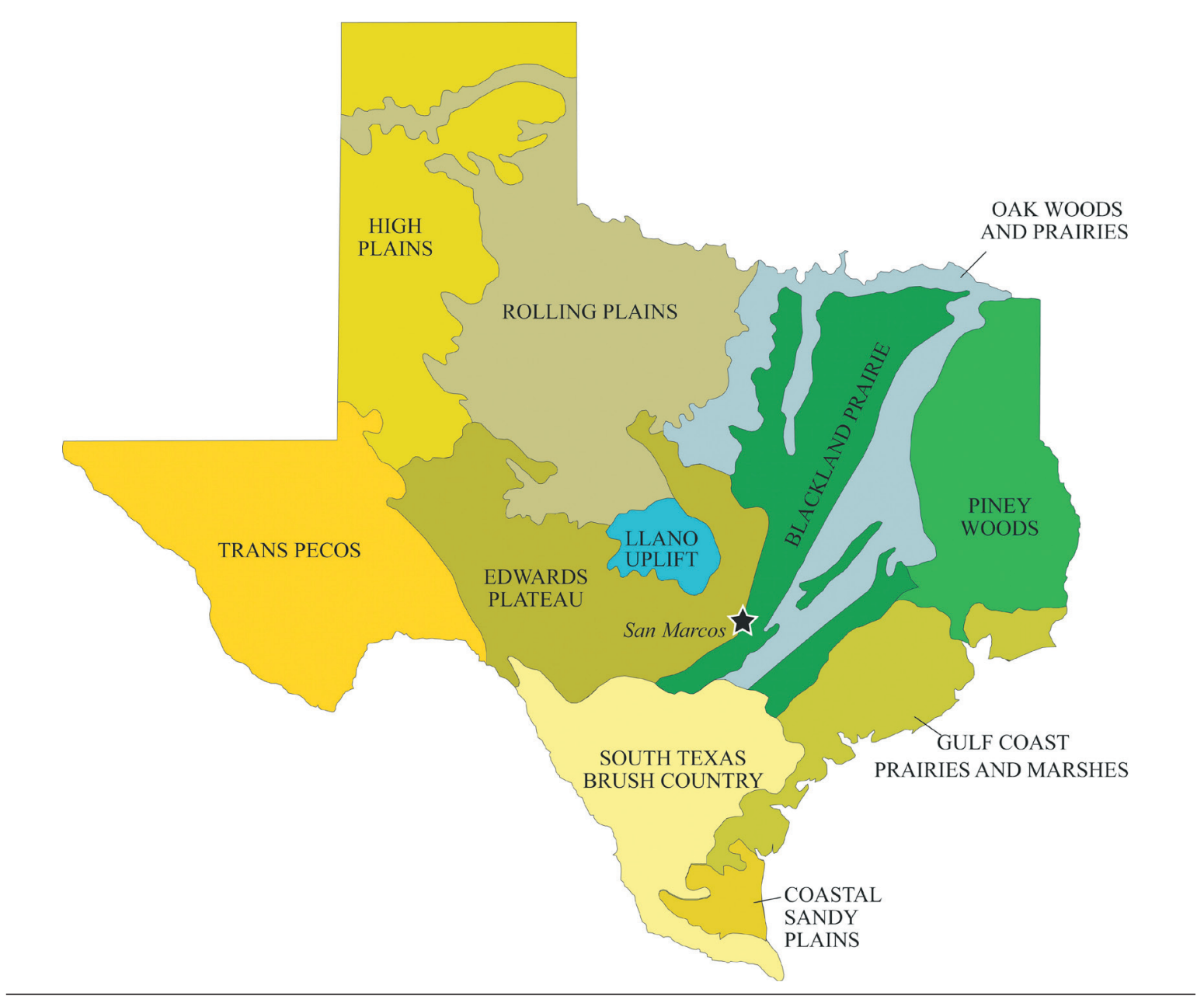

Figure 2-1. Physiographic map showing project area location (black star) in southeast-central Texas.

which proxies record ambient conditions. Consequently, the use of more lines of evidence (i.e., more proxies) results in better paleoenvironmental interpretations.

\section{Geology and Soils}

The entire project area is exclusively within Quaternary Alluvium (Qal), as mapped by the Bureau of Economic Geology (Barnes 1974). Qal are recent flood deposits and therefore composed of unconsolidated materials from surrounding geologic mapping units. The springfed headwaters of the San Marcos River, issuing from Edwards Limestone, are at this location. Sink Creek, also a spring-fed stream, joins the San Marcos River approximately 300 $m$ southwest of the project area. Sink Creek drains a considerable portion of the adjacent uplands, which are composed of a variety of Lower Cretaceous limestones, clays, and shales, namely Edwards Limestone, Del Rio Clay, Georgetown Formation, Eagle Ford Group, and Buda limestone (Barnes 1974). In addition to containing fresh water and contributing to the 
sedimentary matrix of the site, chert-bearing limestone strata, specifically Edwards Limestone, were an important resource for the indigenous, stone toolmaking populations of the region.

Soils in the area, as described by Batte (1984), include Okalla (Ok) and Tinn (Tn) series. Both soil series are deep and form in floodplain settings, and both are typically dark grayishbrown in color, moderately alkaline, and calcareous throughout. Differences in distance from the main channel during floods result in the deposition of differently sized particles. Closer to the stream, Okalla series are composed of slightly coarser (i.e., clay loam) material than the Tinn series (i.e., clay), which is often located at a greater distance from flooding channels. Different proportions of clay fractions in each series influence the degree to which shrink-swell processes, which occur as clay-rich soils alternately dry out and then become wet through seasonal rainfall or floods, affect archaeological deposits. The Tinn series soils have greater potential to disturb archaeological sites through argilliturbation (i.e., mixing of soil as a result of shrink-swell processes).

Combining methods of sedimentary geology and soil science, six depositional units (units) of the Sink Creek/San Marcos Springs valley were identified by Lee C. Nordt (2010) during the 2001 investigations of 41HY160 (Figure 2-2). Units A through F reflect changes in the behavior of Sink Creek, including periods of increased and decreased stream flow, and changes in the resulting depositional regimes. These units were deposited in chronological order, from oldest to most recent, from Paleoindian (A) to Late Prehistoric and Historical periods (F). Incision of the San Marcos River and Sink Creek very late in the Pleistocene flushed out a portion of the valley. Incision was followed by the deposition of channel gravels and fine-grained sediment in a marshy environment during Paleoindian times (A). Another period of incision was followed by similar marsh formation and slow aggradation of flood deposits during the Early Holocene, or Late Paleoindian and Early Archaic times (B and C). Increased deposition of fine-grained sediment marking the middle Holocene, Middle and Late Archaic times (D), was potentially caused by slack water from the Blanco River less than five miles downstream. Diminishing depositional rates, incision of Sink Creek, and gradual accumulation of flood deposits during the late Holocene characterize the environment from Late Archaic/Late Prehistoric times (E) to historical times and the present (F).

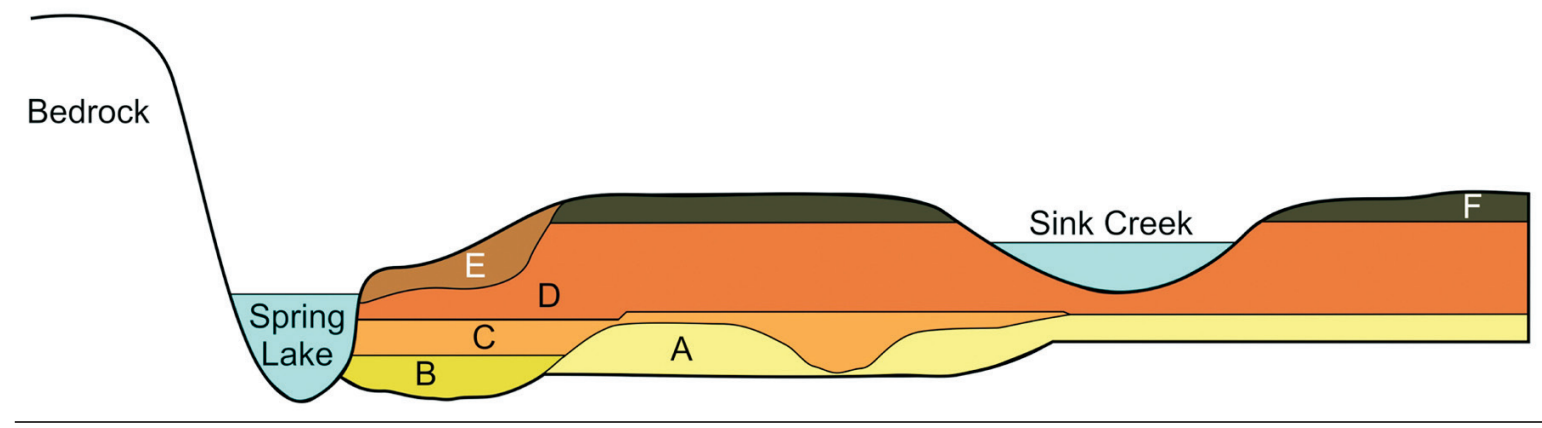

Figure 2-2. Cross section of depositional units in the San Marcos Springs valley (after Nordt 2010: Figure 6-8). 


\section{Chapter 2}

Recent analysis of TxSt-sponsored field school excavations at 41HY160 yields additional site-specific information about past environments and depositional regimes at Spring Lake, including some data that bear directly on the period of the Calf Creek horizon. Using radiocarbon analyses of bison and charcoal and each sample's vertical provenience, an agedepth model of depositional history at the site was created. This model shows relatively high depositional rates from before ca. $6000 \mathrm{cal}$ B.P. to ca. $4300 \mathrm{cal}$ B.P., a period that includes the Calf Creek horizon (Figure 2-3).

Beginning by ca. 4300 years ago, deposits became increasingly mixed, seen in a series of age reversals, where younger dates occur below older ones. This period lasted until approximately 2800 years ago, encompassing the very end of the Middle Archaic and much of the early Late Archaic and generally corresponding with regional-scale environmental perturbations including a sea level rise/highstand suggested by Ricklis (1995) and the warm Edwards Interval posited by Johnson and Goode (1994) (Figure 2-4). Nordt (2010) also notes a decrease in depositional rates across the Sink Creek Valley during this time. Based on available evidence, it seems likely that this portion of 41HY160 was subjected to natural and cultural disturbances of site matrix during a period of relative surface stability.

\section{Weather and Climate}

The Balcones Escarpment strongly influences the weather and climate of Central Texas. Climate in Hays County varies from moist with mild winters and long hot summers, wet all seasons to dry summers (Köppen Climatic Classification: Cfa-Csa, east to west). Climate records of recent history show summers having mean maximum temperatures approaching $97^{\circ} \mathrm{F}$ and winters having mean minimum temperatures near $40^{\circ} \mathrm{F}$. December and January are the coolest months, but subfreezing temperatures have been recorded between October and April (Dixon 2000). Mean annual precipitation recorded for Hays County is 33.75 inches, and falls with bimodal distribution across the year. Late spring and early fall typically experience the most precipitation, but droughts are common to the region (Bomar 1983:153). Not a decade in the twentieth century passed without moisture-deficient conditions.

Central Texas weather is also quite dynamic when viewed along archaeological time scales. Topographic relief from the escarpment can cause orographic cloudbursts to unload relatively high amounts of rainfall over short periods of time. Topography and thin soils, coupled with these precipitation events, can result in flash flooding (Woodruff 1979). These high-energy events have the potential to erode and deposit considerable amounts of sediment within the drainage basins of the region.

For Central Texas, the end of the Pleistocene was generally cooler and wetter than contemporary conditions (Bousman 1998; Musgrove et al. 2001; Nordt et al. 2002). Evidence in the presence/absence of microfauna (Toomey 1993) and phytoliths (Joines 2005) at Hall's Cave, fossil pollens in bogs (Bousman 1998), and stable carbon isotopes in soil (Nordt et al. 2002) suggests that within the generally cool and wet late Pleistocene, there were warmer, 


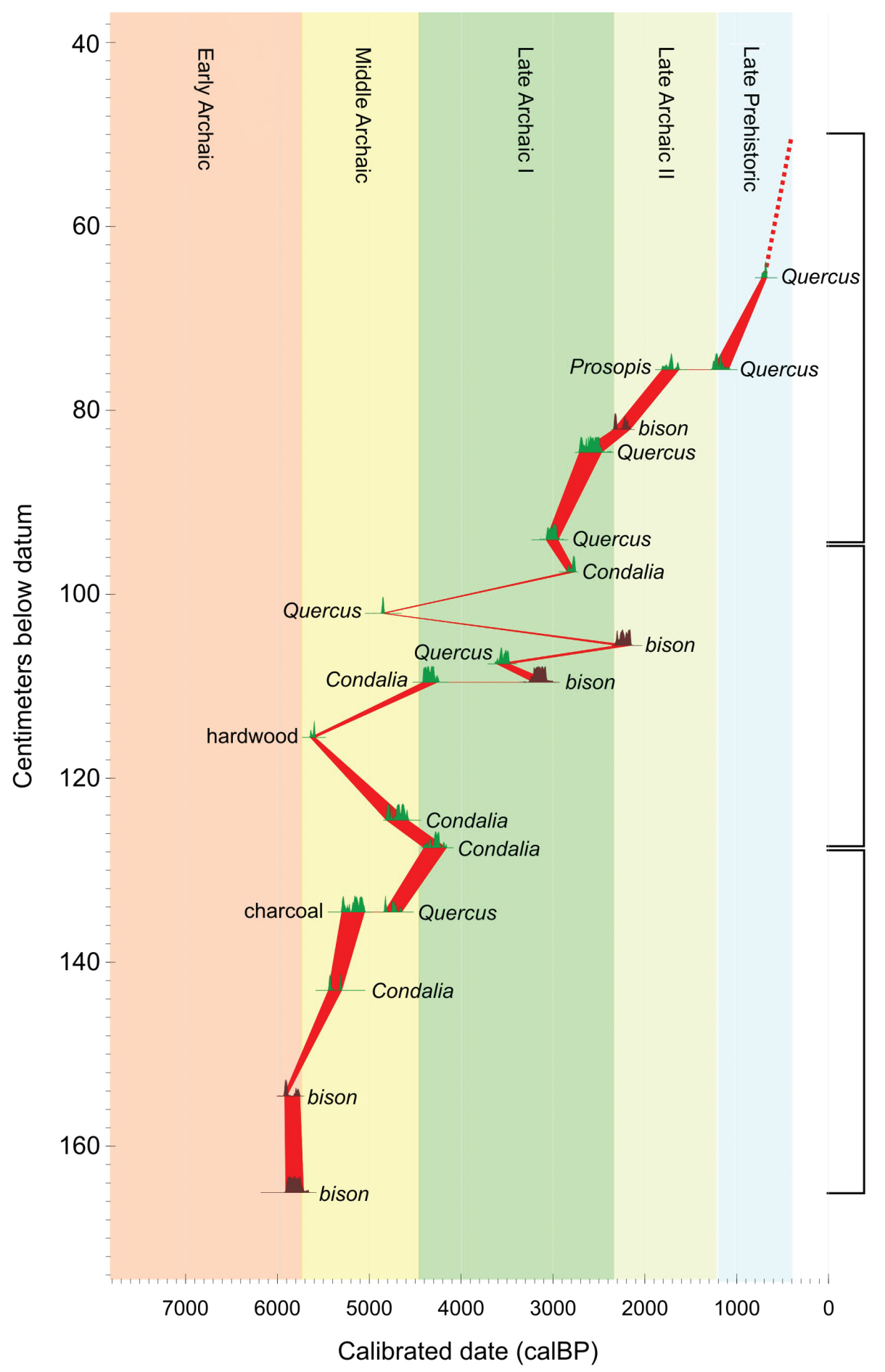

OxCal v4.1.7 Bronk Ramsey (2010); r:5 Atmospheric data from Reimer et al. (2009).

Figure 2-3. Age-depth model of radiocarbon dates by depth from an excavation block near the Ticket Kiosk. The series of reversals between approximately $128-95 \mathrm{~cm}$ below datum, dating to $\sim 4300-2800 \mathrm{cal}$ B.P., corresponds with climatic perturbations noted elsewhere in Texas and the Western Hemisphere. 
Chapter 2
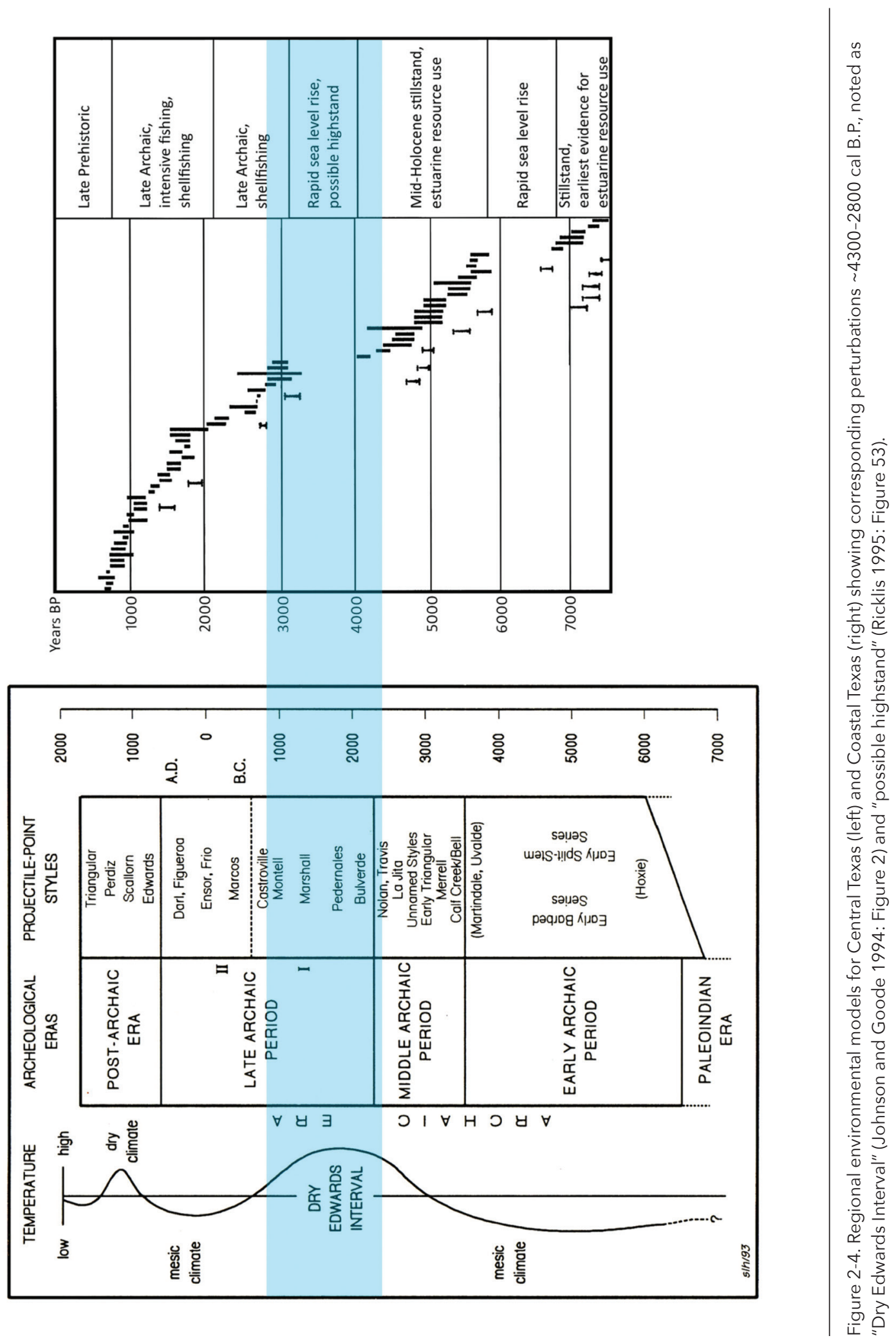
drier intervals. The transition from the Pleistocene to the Holocene is marked by gradual warming, interrupted by a sharp transition to a cool spell known as the Younger Dryas from approximately 12,900 to 11,600 cal B.P. (see Eren 2012), followed by gradually increasing temperatures. Moisture varies independently of temperature, making local and regional reconstructions exceedingly complicated.

During the Holocene, not only did seasonal variation in precipitation and temperature increase (Toomey 1993), but these two variables (temperature and moisture) increasingly varied independently of one another (Figure 2-5). Overall, conditions became warmer, leading to the mid-to late-Holocene Altithermal (Meltzer 1999). It was during this extended event that Calf Creek appeared in the study area. Across much of the Southern Great Plains, the peak of the Altithermal was approximately 5000-6000 years ago. However, in Central Texas, temperature maximums were gradually attained during a trend from ca. 6000 to 2000 B.P.

Generally, the middle and late Holocene is characterized by increasing warmth along with increasing amplitude in precipitation variation. Immediately prior to this trend, temperatures were slightly cooler (compared with later times) but climate was significantly drier. While precipitation fluctuated until around 2000 years ago, temperatures increased rather steadily. Periods of bison exploitation occur during this extended period, beginning with Calf Creek after 6000 years ago (Lohse et al. 2014; see Chapter 5). Gastropods and phytoliths from archaeological contexts in Bexar County confirm the environmental and climatic shifts to xeric conditions (Munoz et al. 2011). Microfauna (Toomey 1993), fossil pollens (Bousman 1998), and stable isotopes (Nordt et al. 2002), as well as alluvial sediment (Blum and Valastro 1989) and

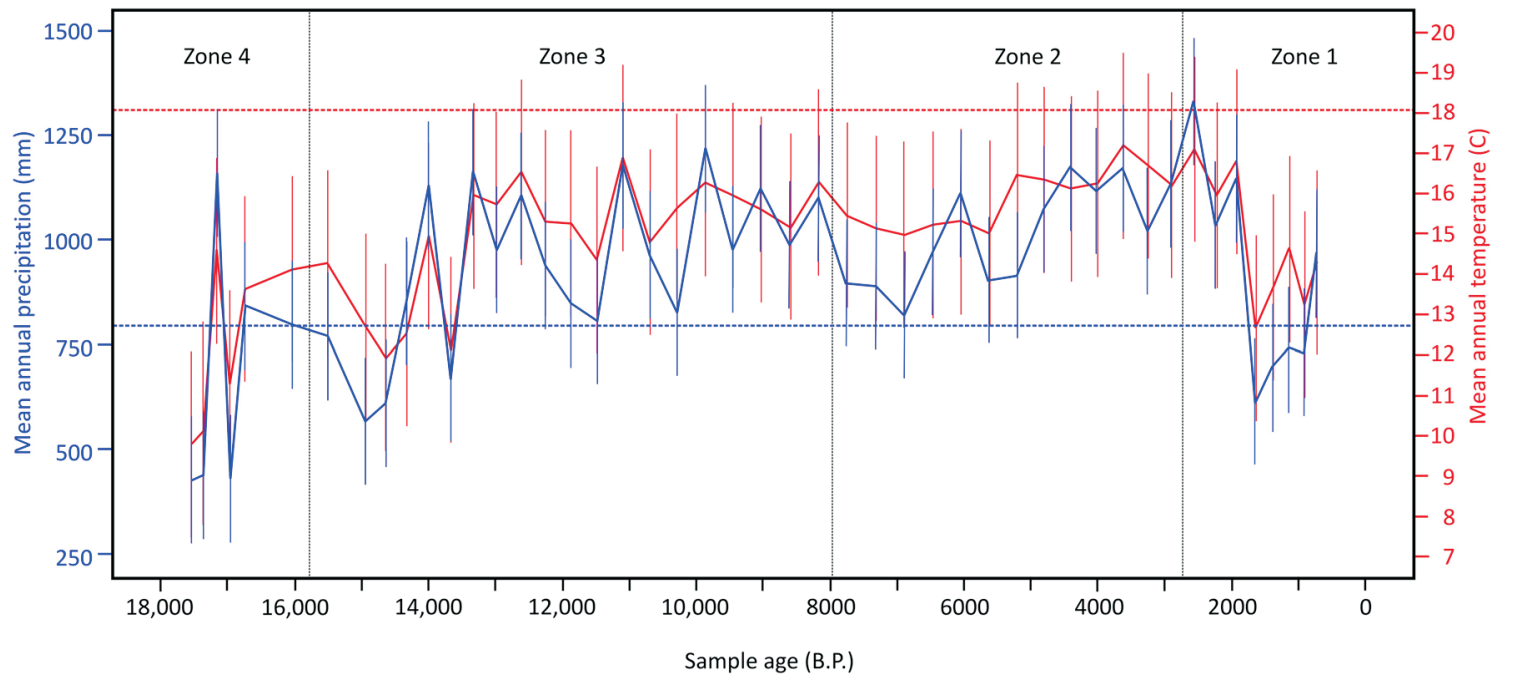

Figure 2-5. Reconstructed mean annual precipitation (blue) and mean annual temperature (red) from phytolith data from Hall's Cave, Kerr County, Texas. These two variables are in general accordance in the Pleistocene record, but they begin to fluctuate independently during the Holocene, after ca. 13,000 B.P. Sample interval is approximately 500 years, which reduces much of the variation that would otherwise be evident (redrawn from Joines 2005: Figures 4 and 5). 
tree rings (Alley 1984; Cook et al. 1999; Mauldin et al. 2012), all indicate that climate following the Edwards Interval was comparably cooler (see Figure 2-5), with oscillations in precipitation.

Interpreting regional records of temperature and precipitation is a challenge for many reasons. Some of the reasons relate to the degree(s) of precision and representativeness of selected proxy lines of evidence. Compounding this issue is the fact that different studies apply different temporal controls, for example using either uncalibrated or calibrated radiocarbon ages, rely on different degrees of temporal precision, and are defined by association issues between actual control dates from a sequence and the proxy evidence used to reconstruct certain variables. In addition to these factors, conditions varied even within study areas such as Central Texas. Given these considerations, the most useful records are those reconstructed directly from data taken from an area under study (such as Spring Lake) that utilize directly dated proxy data (rather than relying on dating-by-association) insofar as possible.

\section{Flora and Fauna}

Floral and faunal species of the adjacent Edwards Plateau and Blackland Prairie commingle along the Balcones Escarpment. Blair (1950) calls this ecotone the Balconian Province, noting that it contains wildlife from every region in the state as well as its own endemic species. Typical modern fauna include armadillo, beaver, black rat, coyote, crayfish, domestic dog, eastern cottontail, eastern gray squirrel, eastern wood rat, muskrat, common opossum, pig, raccoon, red fox, turkey, western diamondback rattlesnake, white-tailed deer, and white-tailed jackrabbit. During some prehistoric times, antelope and bison were also present (Figure 2-6).

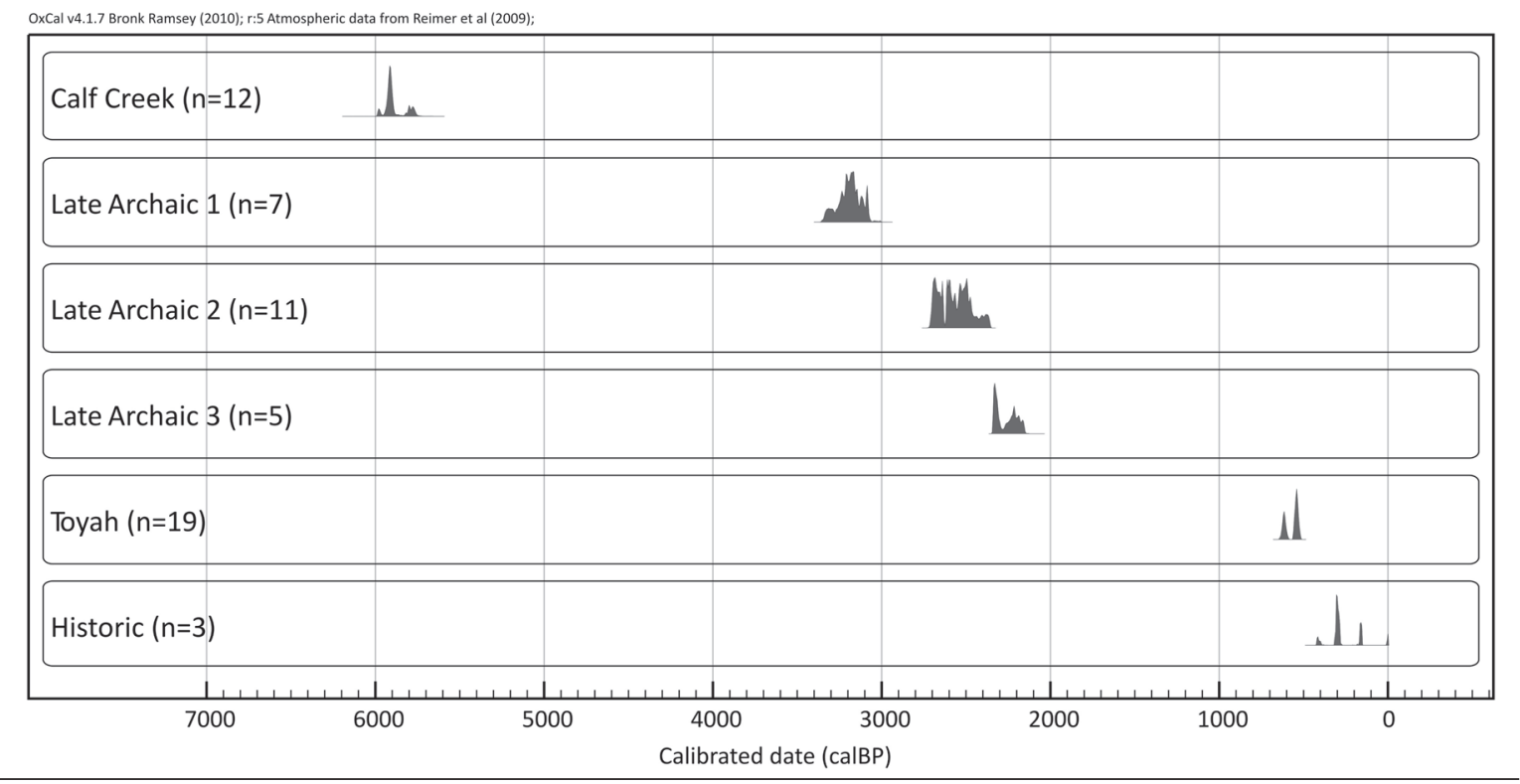

Figure 2-6. Record of directly dated bison from in and around Spring Lake. Cultural periods are discussed below. This model includes bison specimens dated during this project (see Chapter 4). 
The region's natural vegetation is generally a grassland-woodland-forest mosaic, where grasslands separate stands of woody vegetation (Ellis et al 1995). Reconstructed patterns of arboreal cover based on a record of pollen from Boriak and Weakley bogs, not far to the east of the study area, show volatile oscillations between these three zones, oftentimes occurring over relatively brief intervals (Figure 2-7). Many of these oscillations occur too frequently to be strongly associated with clear patterns of cultural adaptation, yet would have posed significant changes to available biomass for foraging populations.

\section{Cultural Context of Study Area}

Human presence in the study region extends from at least Clovis times onward into modern times (Lohse 2013b). Following general convention, this time is divided into three periods: Prehistoric (including Paleoindian, Archaic, and Late Prehistoric), Protohistoric, and Historical. Table 2-1 shows the cultural chronology for Central Texas and identifies timediagnostic point types for each period. All these types, as well as others not listed, are present at Spring Lake. Evidence for prehistoric occupation in and around the San Marcos Springs extends from the Clovis period, approximately 13,500 years ago, up until the arrival of Spanish explorers in the early 1500 s.

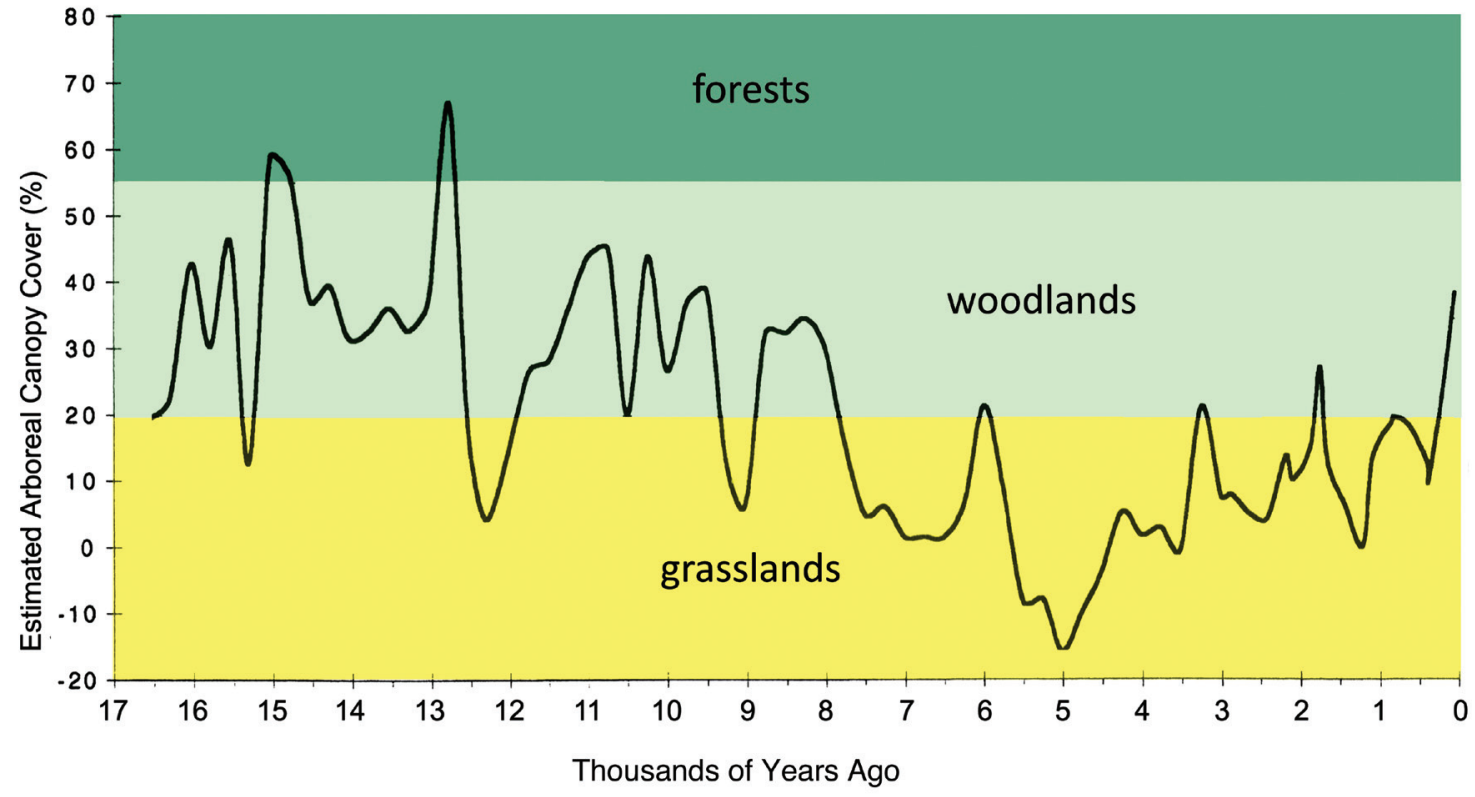

Figure 2-7. Reconstructed tree cover from pollen records at Boriak and Weakley bogs in greater Central Texas, showing sharp oscillations primarily within and between woodland and grassland settings. Forest cover, over $55 \%$ tree canopy, was very infrequent in the study area over the last 15,000 years (from Bousman 1998: Figure 7). 
Table 2-1.

Cultural Chronology for Central Texas

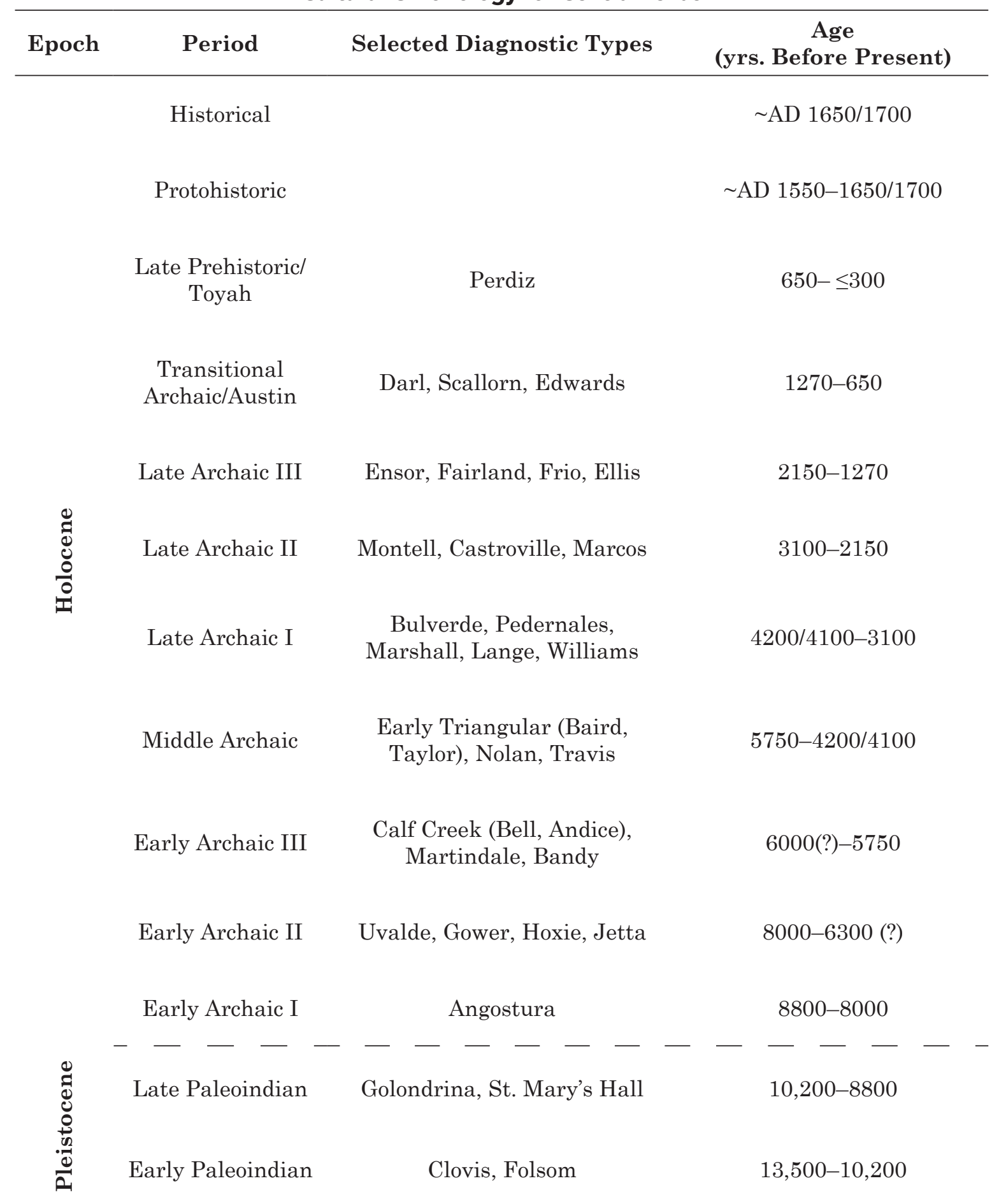




\section{Paleoindian}

The Paleoindian period marks the earliest human occupation of North America and extends until approximately 8800 B.P. Generally, Paleoindian peoples, especially Early Paleoindians, have long been thought of as nomadic wanderers that relied heavily on hunting large game animals such as mammoth, mastodon, bison, camel, and horse (cf. Black 1989). Some large sites, like Gault in Bell County, contain evidence for serial Clovis occupations, suggesting that settlement models for this period also need to account for central place-type camps. Recent research shows that Paleoindians also utilized a variety of plants and animals including badgers, mice, alligators, turtles and tortoises (Black 1989; Collins and Brown 2000; Hester 1983; Lemke and Timperley 2008). Large Pleistocene animal remains have been reported from Spring Lake, including horse, mammoth, and perhaps bison. However, none of these is dated, and fine-recovery methods needed to record evidence of smaller animals have not yet been applied here.

Whereas Clovis points are associated both with large-mammal kill sites and broadspectrum diet linked to encampments like Gault, Folsom points are more closely associated with specialized bison hunting and high mobility across portions of the Great Plains (Meltzer 2006). Indeed, many (but not all; see LaBelle [2012]) Folsom sites suggest a high degree of specialized bison hunting. Most Folsom sites occur as surface scatters, although deeply buried deposits have been uncovered and some sites reportedly contain evidence of structures.

Diagnostic Early Paleoindian point types, including Clovis, Folsom, and Midland, are followed by a number of Late Paleoindian styles, including Golondrina, St. Mary's Hall, Barber, Scottsbluff, and others (Bousman et al. 2004). The diversification of distinctive styles at this time implies population growth and expansion, as sparsely settled parts of the continental landscape became infilled. Spring Lake is notable for the large number of St. Mary's Hall points found here (Shafer and Hester 2013), second only perhaps to the Wilson County Sand Pit. Other Late Paleoindian types from Spring Lake include Angostura, San Patrice, and Wilson. Archaeological evidence suggests that, with the exception of bison (Bison antiquus), large animals of earlier times were extinct before 10,000 years ago. Hunters instead began concentrating on deer, antelope, and other game (Bousman et al. 2002, 2004). Reduced mobility is implied by the concentration of extensive deposits in some sites (like Spring Lake), and also by the diversification of point styles. This behavioral and technological shift followed a sudden warming trend in early Holocene climate, approximately 11,000 years ago. Concurrent with these changes, and also as a result of climate, diets were also transformed as habitats became more diverse. Collectively, these changes signal a new period in prehistoric chronologies, one that archaeologists refer to as the Archaic.

\section{Archaic}

Based on data from numerous sites across North America, archaeologists define the Archaic on the basis of a subsistence pattern heavily reliant on plant foods; new cooking technologies 


\section{Chapter 2}

involving heating stones for their thermal retention properties, grinding stones for processing nuts and seeds, and earth ovens; and, in some locales, the systematic burial of the dead in established cemeteries.

Dating from as early as $\sim 8800$ years ago until approximately 600 years ago, the long Archaic is divided into three parts: the Early, the Middle, and the Late (Weir 1976).

Traditionally, scholars have defined the end of the period by the appearance of bow and arrow technology, around 1200 years ago. However, recent research by CAS (Lohse et al. 2014) suggests that this shift, although important, was relatively insignificant in comparison with other evidence for strong cultural continuity until approximately 650 years ago, and even up until the arrival of Spanish explorers. Accordingly, we describe the Archaic as lasting until almost exactly AD 1300. This limits the ensuing Late Prehistoric to a narrow interval from $\sim \mathrm{AD} 1300$ to the early 1500 s.

\section{Early Archaic}

As previously noted, the beginning of the Holocene is marked by significant climate changes associated with megafaunal extinctions, a turning point that stimulated behavioral changes in land use. For example, groups focused more intensively on the exploitation of local resources such as deer, fish, and geophytes (Thoms 2008, 2009). This dietary adjustment is evidenced by the increased number of ground stone artifacts, accumulated middens of burned and firecracked rock, and woodworking tools such as Clear Fork gouges and Guadalupe bifaces (Turner et al. 2011). The reuse of St. Mary's Hall point fragments from Spring Lake as gouges used in woodworking suggests that many of these activities significantly predate the Archaic (Shafer and Hester 2013).

Michael Collins (1995) places Angostura at the beginning of the Early Archaic, although this point type has traditionally been viewed as a Late Paleoindian style. Regardless, Angostura points mark the stylistic transition from Paleoindian into Archaic times. Although points with well made stems appear earlier (e.g., Wilson points), following Angostura, all Archaic forms are stemmed until the Middle Archaic. Early types falling into this category have bifurcated or split stem morphologies that often grade into one another in terms of style and design. Archaeologists call groups of point types that strongly resemble one another in form a series (Jelks 1978); the Early Archaic series has proven extremely difficult for Texas archaeologists to separate with greater precision. From Spring Lake, these include Jetta, Hoxie, Uvalde, and Gower points, all of which bear stylistic similarities.

Based on theoretical expectations derived from global studies of hunter-gatherer-fishers as well as data from South and Central Texas (e.g., Johnson and Hard 2008), the cultural landscape of the study area probably surpassed a significant threshold in population density by the Early Archaic. A number of important adaptations and behaviors are evident in response to this development. First, since at least 7000 years ago, regional population dynamics reached a relative degree of stability, with territorial limitations imposed by what archaeologists 
call "population packing," or densities of more than 9 individuals per $100 \mathrm{~km}^{2}$ (Thoms 2008) "Stability" is seen here minimally in the appearance of cemeteries that show repeated use. In particular, two from Victoria County - the Morhiss Site (Hard and Katzenberg 2011) and the Buckeye Knoll Site (Ricklis 2011) —are among the oldest cemeteries in North America. Each had human interments by at least 7000 years ago, and both were used intensively for long periods of time. Additionally, style intervals for many diagnostic tool forms commonly endured for 300 years or more, suggesting conservative rates of change and innovation. For example, the types characterizing the Early Archaic II subperiod (see Table 2-1) are all stylistically similar, and span approximately 1700 years. This technological and stylistic longevity illustrates a conservative rate of technological change and provides additional evidence of stability.

Lewis Binford (2001) notes that this kind of population packing is only possible through subsistence intensification (also described by Johnson and Hard 2008, and Thoms 2008), or the production of greater quantities of food through increasingly labor-intensive techniques and processes. The use of hot-rock cooking technology to process wild bulbs and tubers and an increased reliance on riverine resources exemplify the subsistence intensification that occurred in Central Texas. (Prehistoric groups in the study area never practiced agriculture, which would have been the culmination of this process of subsistence intensification.) Still, within this gradually evolving land-use system, food resources that returned high yields with relatively low labor requirements to procure or process would have remained important; specifically, these resources included large game animals.

Tom Dillehay (1974) proposed a model for the Southern Plains that described the widespread presence of bison, including both Bison antiquus and modern Bison bison, throughout the Early Archaic. When exactly the modern form appeared is not well known, but the antique species would have been extinct before the end of the Early Archaic. Data from the region surrounding San Marcos confirming the continual presence of bison throughout the Early Archaic is lacking. However, a number of directly dated bison remains from Spring Lake establish the presence of modern bison in the region during a narrow interval of 6000-5750 years ago (Lohse et al. 2012). These dates begin to define the Calf Creek horizon (Wyckoff 1994, 1995) as it occurred at Spring Lake. The present study adds important chronometric, stylistic, and geoarchaeological context to the Calf Creek component at Spring Lake. Based on previous work (Lohse 2013a), Calf Creek defines the terminus of the Early Archaic.

Based on these theoretical models plus available data, which remain limited in many respects, the Early Archaic can be understood as a period of "settling in" across Central Texas and elsewhere. This process almost certainly started in earlier, Late Paleoindian times, even though established regional traditions become clearly evident, based on cemeteries, in the Early Archaic. In addition to other labor-intensive food-procurement activities, the reliance on large game, specifically bison, was a very important aspect of lifeways during this period. Technologically, a great deal of continuity is seen in tool and point forms during the early period of the Early Archaic. Late in the period, Calf Creek materials, distinguished by 


\section{Chapter 2}

characteristically deep basally notched, triangular-form Bell and Andice points (see Figure 1-4), may have emerged from preceding point types that are similar in shape but that are corner notched.

\section{Middle Archaic}

Based in large measure on the absence of bison in the archaeological record at Spring Lake following the Calf Creek interval, the Middle Archaic begins approximately 5750 years ago (see Table 2-1). Regionally, this period is closely associated with the Altithermal (see above). As the Altithermal progressed, conditions in South and Central Texas became ever warmer and drier, to the degree that locating campsites near reliable water sources became increasingly important. Regionally, finding any sites with intact deposits from this time period is difficult. Arid conditions led to reduced ground cover, which in turn is associated with increased soil erosion during rainfall events. As a consequence, relatively few landforms containing wellpreserved remains from this period have been identified for investigation by archaeologists. Middle Archaic deposits from Spring Lake, however, are comparably extensive, even if they are somewhat mixed, especially near the top of this stratum (Lohse 2013a; see Figure 2-3).

Stylistically, stemmed projectile points disappeared along with the bison at the beginning of this period. Instead, triangular forms called Taylor and Baird, commonly subsumed into one type called Early Triangular, are common. Impact damage on some of these projectile points indicate that they were used in hunting. However, many were also clearly used as knives and for other, more general purposes. Other than the absence of bison, subsistence practices remained largely unchanged from the previous period. An important possible exception to this statement is what appears as a distinct increase in fire-cracked rock at the end of the Middle Archaic and beginning of the ensuing Late Archaic (Yelacic 2013). This increase constitutes a shift toward greater dietary intensification through increased usage of earth ovens for processing geophytes (cf. Thoms 2008).

By the latter part of the Middle Archaic, stemmed projectile points, including types such as Nolan and Travis replaced Early Triangular styles. Given the poor geologic context of many sites from this period, the exact timing of this transition has not yet been well dated. While both Nolan and Travis are distinct from earlier styles, they are highly comparable to each other, and also to newly defined types, such as Evant (see Shafer and Hester 2013) that grade into the early part of the following period, the Late Archaic. The end of this period is dated at around 4200-4100 years ago (Lohse et al. 2014).

\section{Late Archaic}

The Late Archaic represents in many ways continuity from the preceding period. However, this period lasted longer, from around 4200 years ago until AD 1300 (approximately 700 years ago), a total duration of approximately 3500 years. Accordingly, it encompassed much more variation in terms of projectile point styles and associated cultural patterns than the Middle 
Archaic. Late Archaic 1 lasted from approximately 4200 to 3100 years ago. Late Archaic 2 dates from about 3100 to 2150 years ago. The final period, Late Archaic 3, lasted from 2150 to around 1270 years ago. (Precision implied by these dates should not be taken literally; these age ranges are only approximations based on available data). Important periods of bison hunting, indicated by 55 high-precision dates taken directly from remains excavated from Spring Lake and a nearby site (41HY188) help to provide a basis for distinguishing between these subperiods (Lohse et al. 2014; see Figure 2-6).

In terms of diagnostic types, Late Archaic 1 is characterized by Bulverde and Pedernales points, as well as other, less common forms. Pedernales points, in particular, are among the most common point types of any prehistoric period in the region, and some archaeologists have argued that the frequency of this type is a reflection of high overall populations in Central Texas. Considering that this period coincided with the peak of Johnson and Goode's (1994) Edwards Interval (see Figure 2-4), archaeologists can surmise that environmental conditions might not have been ideal for supporting any sudden or large population growth. This period included, and concluded with, the first reappearance of bison into the region since Calf Creek times, around 3200 years ago. Whether Pedernales points are associated with bison has yet to be demonstrated; Marshall may be a more probable candidate for this technological adaptation.

Late Archaic 2 is defined almost exclusively by the close association of a distinctive series of types, including Montell, Castroville, and Marcos, with bison hunting across much of Central Texas and beyond. All three of these types occur at Spring Lake, and a number of bison remains have been directly dated to this interval.

The Late Archaic 3 period seems to represent the onset of another prolonged absence of bison remains from the study area. Work at Spring Lake indicates that these important animals disappeared from the regional landscape somewhat abruptly around 2150 years ago. Sites to the north, close to the Texas-Oklahoma border, commonly show strong evidence for continued bison hunting, and it seems that regional climates at this time changed to the point that better or more desirable forage was no longer available in hunting grounds anywhere close to Spring Lake. Diagnostic points from this period that have been recovered from Spring Lake include Ensor, Fairland, Frio and others.

Aside from the changes in bison frequencies in the region throughout the Late Archaic, archaeologists view this period as one of relative continuity and cultural stability. Many of the site location patterns, subsistence strategies, and technological choices remained relatively constant over these 3,000-plus years. One important development includes the appearance (again) of several large cemeteries that seem to mark regional territories. Although some Middle Archaic interments are known, the scale and magnitude of burial practices in the Late Archaic exceeds that known for any previous time period in terms of cemeteries on the landscape. Cemeteries at sites such as Ernest Witte in Austin County (Hall 1981) and Olmos Dam in San Antonio (Lukowski 1988) have been used to postulate that populations increased and that some groups were perhaps once again becoming territorial (Story 1985:44-45). 


\section{Transitional Archaic/Austin}

Traditionally, the appearance of the bow and arrow, visible in the record with the introduction of Scallorn points around AD 800, has been used to mark the end of the Archaic and the beginning of what archaeologists call the Late Prehistoric period. However, no one yet knows precisely when the bow and arrow was adopted in Central Texas, and it seems most likely that this technological adaptation was gradual rather than abrupt. Although the bow and arrow was an important development over previous methods for propelling spears and darts at game animals or people, the overall record of the region shows a great deal of continuity in almost all other respects, suggesting that the bow and arrow did not actually mark a significant shift in many cultural patterns (see recent summary by Arnn 2012:167-168). Some examples of behavioral continuity include a broad-spectrum diet, continued reliance on bifacial stone tool technologies, mortuary practices, and site distribution and settlement patterning. As a result, Lohse et al. (2014) define the end of the Archaic by combining what some have called the Transitional Archaic with the Austin phase, characterized by the bow and arrow and which marks the beginning of the Late Prehistoric.

Bison data provide another compelling reason for defining the end of the Archaic in this manner. Following the period of bison hunting that defines Late Archaic II, no bison remains from the study area are dated earlier than $\mathrm{AD} 1300$. Among all available classes of data, this distinction is among the clearest and best defined (see Figure 2-6). In contrast, our review of existing radiocarbon dates from across the region shows the continual, gradually changing preference for time-diagnostic point types, from Ensor and Frio to Darl and Scallorn, the earliest arrow point type known in the study area.

\section{Late Prehistoric}

Historically, the Late Prehistoric is separated into two phases, Austin and Toyah (Jelks 1962). As discussed above, we include Austin with the Transitional Archaic, and limit the Late Prehistoric in Central Texas to the Toyah interval, which seems to start immediately around AD 1300. Archaeologist John Arnn (2012) describes Toyah as a time when coalitions of Native American groups were actively traversing the Central Texas region, resulting in widely shared artifact technologies and styles. Others have argued, persuasively we think, that one primary impetus to this shift in mobility and cultural interaction was an intense, focused exploitation of bison. At this time, many Plains cultures far to the north of Central Texas were actively exchanging bison meat and hides with Pueblo villages to the west and complex societies in the Mississippi River drainages and tributaries to the east (Spielmann 1991). Trade goods from external areas, including obsidian, turquoise, and exotic ceramic styles appear more commonly than in previous times, supporting this view of the Late Prehistoric.

Dating the end of Toyah is complicated, as several material traits clearly extend into the early part of the Historical period. Perdiz arrow points are the most common type from this period, although others are also found in Late Prehistoric assemblages from elsewhere. 
Some Perdiz styles, made of glass, have been recovered from Spanish Mission contexts in San Antonio (Lohse 1999), attesting to the prolonged interaction between Native American peoples and early European colonizers. Reasonably, it is difficult to recognize "Toyah" patterns in the material record after around $\mathrm{AD} 1700$ or so, and even this late date is problematic in many respects. Rather, as the Spanish and French mission era took hold across parts of Texas, most aboriginal societies were assimilated, died off from disease or conflict, or left. A few remain, but most are gone forever.

\section{Protohistoric (Spanish Entrada) Period}

The Protohistoric represents a period of time when European explorers began traversing and settling the region. This transitional period contains a few written records that, although fragmentary, are important for characterizing the rich cultural diversity of the region that assuredly was also present prior to Spanish arrival as well (Arnn 2012). Historical documents record the use of the springs by Spanish and Native American groups in the seventeenth, eighteenth, and nineteenth centuries, and as early as the mid-nineteenth century by AngloAmericans such as General Edward Burleson.

The Protohistoric period was marked by Spanish entradas, formal expeditions into Texas in the late seventeenth and early eighteenth centuries. Hester defines this as "the transition period between the Prehistoric and Historical period denoting a phase for which few written records are available, and for which most evidence is derived from archaeology" (1995:449450). This period began with the venture by the Spanish explorer Cabeza de Vaca and the Narvaez expedition in 1528 and extended to the establishment and abandonment of Spanish missions, including the Mission San Antonio de Valero (the Alamo) in 1718 and others.

When the Spanish missions were established in East Texas in the late 1600s, entradas began to travel regularly through the study area. These expeditions provide the first detailed observations on the original Native American inhabitants of the region. With Alonso de León's expedition of 1680, El Camino Real (the King's Road) was established from Villa Santiago de la Monclova in Mexico to East Texas. This roadway followed established Native American trade routes and trails, and became a vital link between Mission San Juan Bautista in Northern Mexico and the Spanish settlement of Los Adaes in East Texas (McGraw et al. 1991).

Spanish priests accompanying entradas provided most of the available information on Native American cultures of early Texas. The few surviving accounts of indigenous groups in Texas reveal a dynamic cultural environment in which numerous tribes passed through or inhabited Central Texas at different periods. Little is known about most of these tribes, but those documented around the springs at San Marcos include the Cantona, Muruam, Payaya, Sana, and Yojuane. Other tribes encountered at San Marcos included mobile hunting parties from villages in South and West Texas, including the Catequeza, Cayanaaya, Chalome, Cibolo, and Jumano, who were heading for bison hunting grounds in the Blackland Prairies (Foster 1995:265-289; Johnson and Campbell 1992; Newcomb 1993). Later groups migrated into the 


\section{Chapter 2}

region, displacing the former groups or tribes. These included the Tonkawa from Oklahoma, and Lipan and Comanche from the Plains (Campbell and Campbell 1985; Dunn 1911; Newcomb 1961, 1993). Archaeological sites dated to this period typically contain a mix of both imported European goods, such as metal objects and glass beads, and chipped stone tools.

Spanish settlement in Central Texas first occurred in San Antonio with the establishment of Mission San Antonio de Valero, and the later founding of San Antonio de Béxar (Bolton 1970; de la Teja 1995; Habig 1977). Between 1746 and 1755, three missions, San Francisco Xavier de Horcasitas, San Ildefonso, and Nuestra Señora de la Canderlaria were located somewhere along the San Gabriel River (known at the time as the San Xavier) in present-day Milam County. The three missions were eventually coalesced into one, the San Xavier Mission, and moved to the San Marcos River in 1755. A petition to permanently establish a mission in Apache territory resulted in the founding of the San Sabá Mission, near present-day Menard, in 1757. Neophytes from the San Xavier Mission in San Marcos were transferred to the San Antonio missions and the mission's property and presidio were reassigned to the San Sabá Mission. A small group of local San Xavier Indians, the Mayeyes, persuaded the missionaries to set up a new mission for them on the Guadalupe River, to be named the San Francisco Xavier Mission, but it only lasted until 1758 (Bolton 1970[1915]). The precise location of the San Xavier Mission along the San Marcos River has not yet been determined.

Besides the mission town of San Antonio, the only other Spanish settlement in the region was the town San Marcos de Neve, established in 1808, four miles south of present-day San Marcos. San Marcos de Neve was abandoned in 1812 as a result of constant raids by local tribes (Dobie 1932). During this time, massive depopulation occurred among Native Americans due to diseases to which indigenous people had little resistance. Those few remaining were gradually displaced to reservations beginning in the mid-1850s (Fisher 1998).

\section{Previous Investigations}

Six archaeological sites are recorded within the vicinity of the Ticket Kiosk excavation. These are 41HY37, 41HY147, 41HY160, 41HY161, 41HY165, and 41HY306. Work has been conducted intermittently at these sites for a number of years (Table 2-2). Cumulatively, the results of this work, as well as the ongoing analyses discussed previously in this chapter, have resulted in an increasingly complete picture of the overall extent, nature, and timing of prehistoric and protohistoric occupation at this important site. 
Table 2-2

Previously Investigated Sites in the Spring Lake Vicinity

\begin{tabular}{|c|c|c|}
\hline Site & Components & Citations \\
\hline 41HY37 & $\begin{array}{l}\text { Historical Burleson homestead; } \\
\text { Late Prehistoric and Late Archaic } \\
\text { (Late Archaic: Pedernales and } \\
\text { Edgewood points) }\end{array}$ & $\begin{array}{l}\text { Bousman and Nickels 2003; } \\
\text { Garber and Orlof } 1984\end{array}$ \\
\hline 41HY147 & $\begin{array}{l}\text { Archaic, Late and Early Paleoin- } \\
\text { dian, Pleistocene fauna }\end{array}$ & $\begin{array}{l}\text { Shiner 1983; } \\
\text { Takac 1990, 1991a, 1991b }\end{array}$ \\
\hline 41HY160 & $\begin{array}{l}\text { Discrete components from Late } \\
\text { Prehistoric through Early Archaic, } \\
\text { domestic features }\end{array}$ & $\begin{array}{l}\text { Aery 2007; } \\
\text { Nickels and Bousman 2010; } \\
\text { Garber et al. 1983; } \\
\text { Oksanen 2006; } \\
\text { Ramsey } 1997\end{array}$ \\
\hline 41HY161 & $\begin{array}{l}\text { Mixed historical and Archaic, Late } \\
\text { Archaic, Late and Early Paleoin- } \\
\text { dian, human remains, Pleistocene } \\
\text { fauna }\end{array}$ & $\begin{array}{l}\text { Ford and Lyle 1998; } \\
\text { Garber and Glassman 1992; } \\
\text { Jones 2002; } \\
\text { Leezer et al. 2010; } \\
\text { Lyle et al. 2000; } \\
\text { Oksanen 2008; } \\
\text { Shiner 1979, 1981, 1984; } \\
\text { Stull and Hamilton 2011; } \\
\text { Yelacic et al. 2008b }\end{array}$ \\
\hline 41HY165 & $\begin{array}{l}\text { Prehistoric, Middle Archaic, bison, } \\
\text { historical, mixed historical and } \\
\text { prehistoric }\end{array}$ & $\begin{array}{l}\text { Giesecke 1998; } \\
\text { Ringstaff 2000; } \\
\text { Soucie and Nickels 2003; } \\
\text { Soucie et al. } 2004\end{array}$ \\
\hline 41HY306 & Late Archaic, Late Paleoindian & Arnn and Kibler 1999 \\
\hline
\end{tabular}





\section{Chapter 3 Data Recovery Objectives and Methods}

by Jon C. Lohse

Inasmuch as previous investigations at $41 \mathrm{HY} 160$ had concluded that archaeological materials in this area are well preserved and in good stratigraphic context, data recovery excavation and monitoring focused on compensating for the potential loss of information from the proposed construction. The primary goal of the mitigation activities described in this report was to acquire a high-quality dataset that would contribute to a better understanding of prehistoric occupations within the project area, specifically with respect to chronological precision around the end of the Early Archaic and the subsequent transition into the Middle Archaic period.

In order to achieve a suitable dataset, project objectives were aimed at recovering stratified time-diagnostic material. A related objective was to recover datable organic materials from primary contexts, either associated with archaeological features or from clearly identifed stratigraphic units. Existing data from the nearby 2001-2006 field school block allowed analytical attention to be focused on portions of the deposits that minimally overlap with previously defined portions of the cultural sequence present in this part of 41HY160. In addition to attention to dating the deposits in this location, descriptive analyses of lithic and faunal materials and also of features were conducted with stratigraphic contexts in mind. Combined with existing data, the information acquired from the present project contributes to overlying research questions that consider prehistoric economy, technology, and mobility within the context of environmental changes through time at Spring Lake.

Fieldwork consisted of two separate activities: controlled hand excavations of $1 \times 2 \mathrm{~m}$ units and the monitoring of mechanical scraping and trench excavation for the installation of associated utilities. Each set of activities required an appropriate methodology in order to address the stated research objectives while also recovering potentially important information or recording sensitive deposits that were likely to be exposed during the project. Careful attention to the monitoring phase of this project, in particular, was important, inasmuch as on-site archaeologists were able to identify an intact burial cairn feature during the excavation of a utility trench before the feature 


\section{Chapter 3}

was unduly damaged. In addition to field methodologies, laboratory approaches to cataloging and inventorying recovered remains are described in this chapter.

\section{ExCAVATION}

Fieldwork initially was to involve the excavation by hand of two $1 \times 1 \mathrm{~m}$ units (Units 1 and 2) in order to determine the nature of cultural deposits in the proposed location of the lift station. The area of excavation was first scraped by backhoe in order to remove the paving surface and sub-pavement base. Next, the two units were laid out adjacent to each other (Figure 3-1), and excavations commenced in arbitrary $10 \mathrm{~cm}$ levels. Excavations were to extend to $3 \mathrm{~m}$ below the ground, the projected depth of the lift station that was to be installed in this location. Matrix recovered from all units was passed through $1 / 4$-inch wire mesh screen. Artifacts observed on the screen were collected and cataloged by provenience (i.e., unit/level). Features were recorded and removed as they were exposed. Carbon samples were recorded and collected in situ and from the screen. As an additional measure of sampling, a continuous column of bulk sediment samples was collected from surface to the bottom of the excavations once they were completed. Additional sediment samples were collected in and around features.

Vertical control was provided by an arbitrary elevation datum established near the edge of the units. Measurements taken from this datum defined the beginning and ending elevations of each excavation level.

At approximately $60 \mathrm{~cm}$ below the opening elevation, an unmarked gas line was encountered running diagonally across Units 1 and 2, and the two units were abandoned.

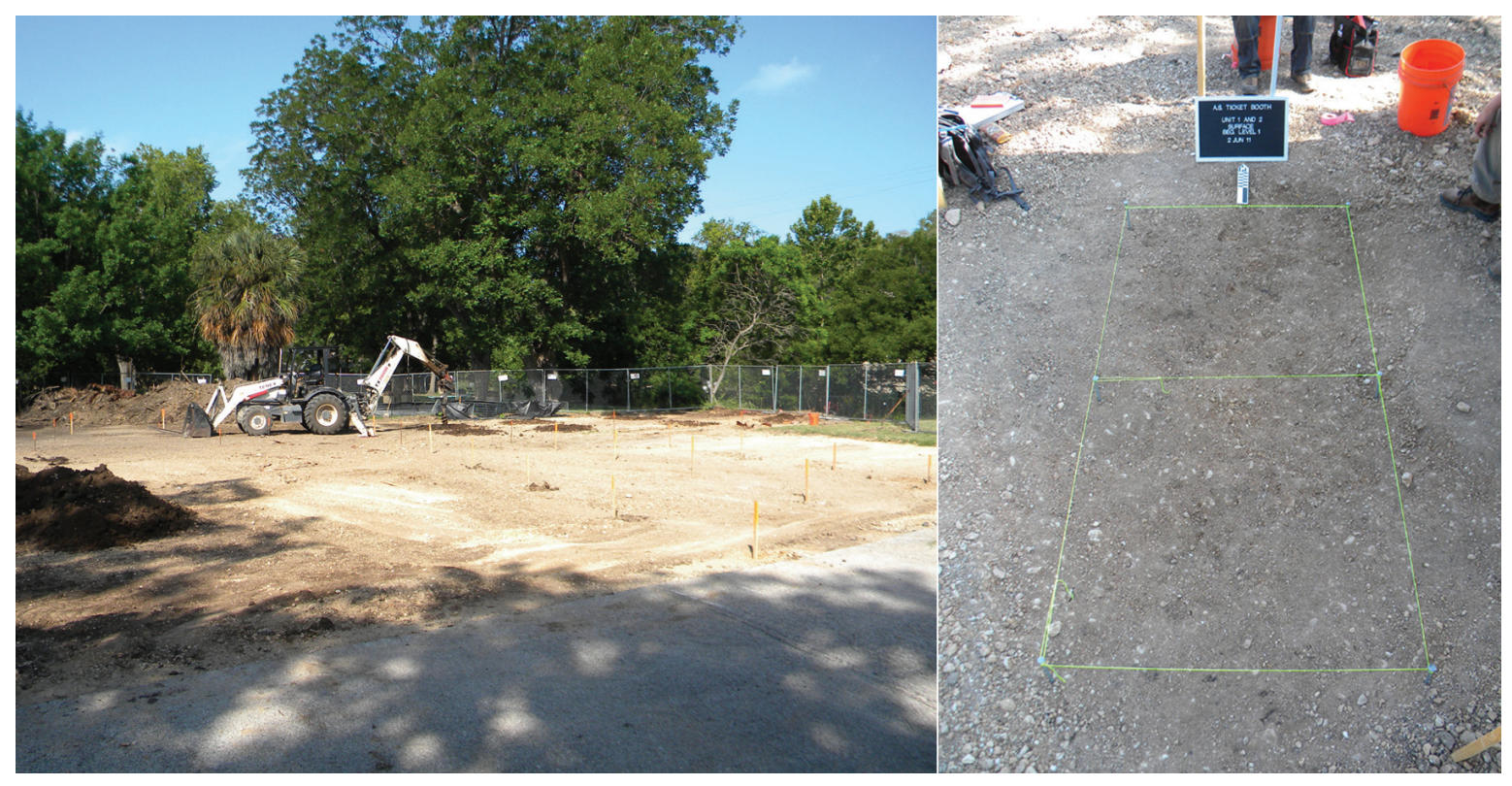

Figure 3-1. Overview of project area after parking surface has been scraped (left) and Units 1 and 2 prior to excavation (right). 
Two new units (Units 3 and 4) were established immediately adjacent to the first two (Figure $3-2)$. As a result, a total of four $1 \times 1 \mathrm{~m}$ units were excavated, although the first two of these contained disturbed sediments from the gas line, were abandoned at $60 \mathrm{~cm}$, and do not factor into the overall analysis reported here.

After excavations reached $1.2 \mathrm{~m}$ in depth, a section extending two feet in all directions around the hand-excavated unit was mechanically stripped in order to bench sidewalls for safety. This work was closely monitored by CAS archaeologists, and all time-diagnostic artifacts encountered were collected and are included in the artifact catalog. Hand excavations resumed and continued to a depth of three meters below datum with the same recovery and sampling strategies as the upper 1.2 meters. Upon reaching the water table approximately 20 $\mathrm{cm}$ above the bottom of the units, the units were hand-bailed in order to continue excavating (Figure 3-3).

Documentation consisted of a daily journal, scaled drawings, level summary forms and digital photographs. In addition, unit profiles were recorded with scaled drawings and by digital photographs. All artifacts encountered were recovered and recorded by provenience (unit and level). The locations of the four $1 \times 1 \mathrm{~m}$ units were recorded with a GeoXT hand held GPS system with sub-meter accuracy and integrated into a database of Spring Lake cultural resources.

\section{Monitoring}

Following manual excavations of Units 3 and 4, CAS archaeologists monitored a series of mechanical excavations that were necessary for associated utilities and additional aspects of the construction plan for the new ticket kiosk. First, 39 auger excavations, intended to accommodate deep piers designed to support the floating foundations of the two structures,

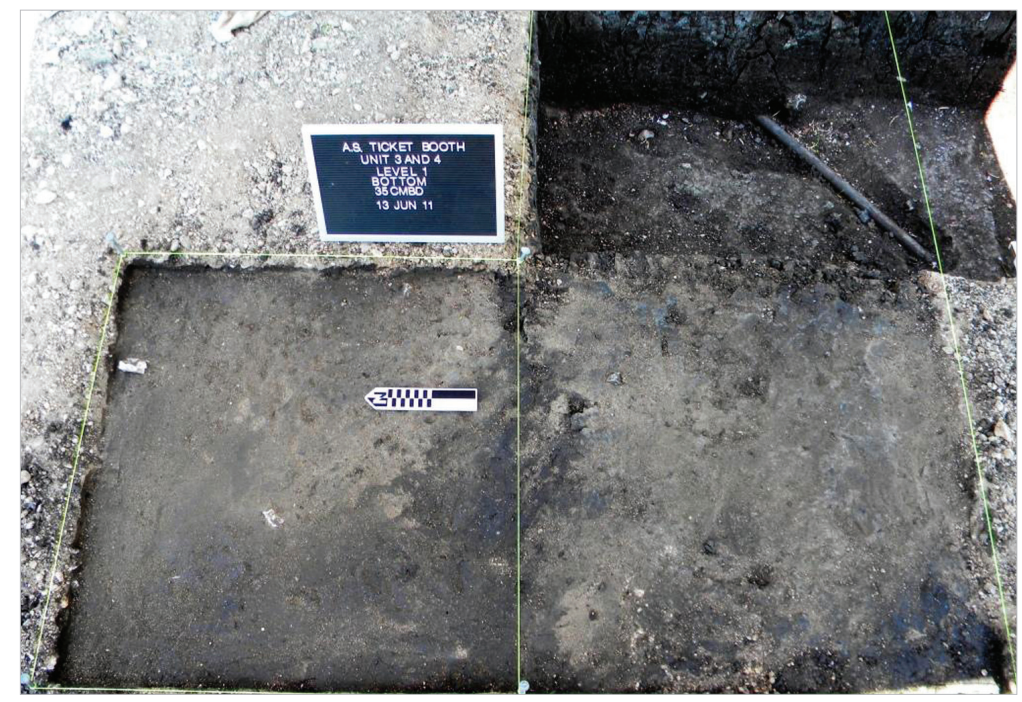

Figure 3-2. Units 3 and 4, adjacent to Units 1 and 2 after the gas line (visible at top) was encountered. 


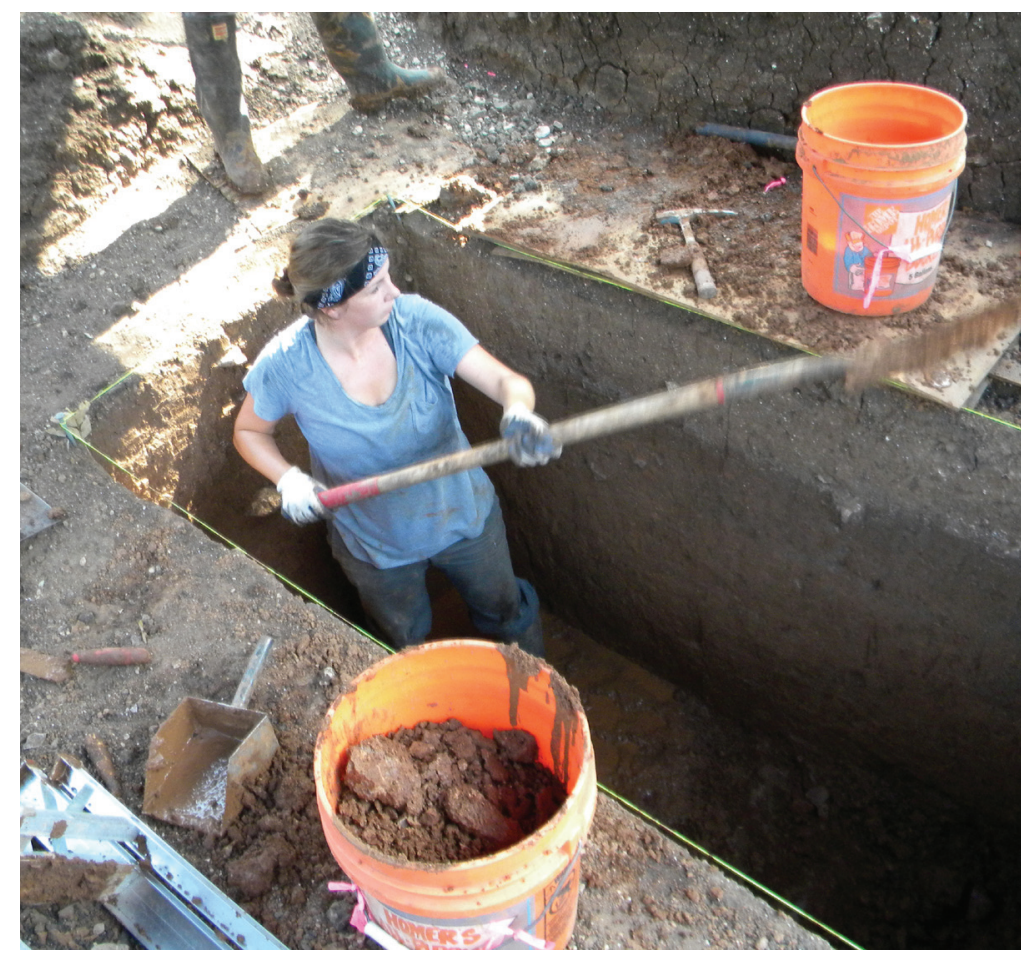

Figure 3-3. Cleaning out the waterlogged lowermost sediments from Units 3 and 4. The mechanically stepped area can be seen surrounding the units.

were monitored. Each auger excavation measured approximately 12 in (ca. $30 \mathrm{~cm}$ ) in diameter and reached a maximum depth of $6 \mathrm{ft}(1.85 \mathrm{~m})$. Displaced sediment was examined for cultural materials contained therein. Each auger was numbered and their approximate locations were sketched on a plan-view map. All artifacts encountered were recorded by provenience (auger number), and time-diagnostic material as well as bison remains were collected.

In addition to the auger holes for installation of construction piers, various trenches were excavated in order to locate and install utility lines. These included trenches for installation of plumbing for the restroom facility and electricity for the new buildings. It was in one of these electric utility trenches that CAS personnel identified the burial feature. Also, CAS archaeologists monitored the mechanical excavation of a relatively large area to the south of the proposed facilities, where the City of San Marcos's utility crew attempted to locate a water main. On another occasion CAS archaeologists monitored two trenches excavated to expose and connect an existing irrigation line with a meter box. The final monitoring event consisted of preparatory excavation (scraping) for the installation of a walkway and access drive. Monitoring of trench excavations and scraping consisted of recording approximate proveniences of artifacts encountered, as well as collecting time-diagnostic material. The locations of all auger and trench excavations were recorded with a Trimble GeoXT hand-held GPS system with sub-meter accuracy and integrated into CAS's database of Spring Lake 
cultural resources (Figure 3-4). All of these mechanical excavations were also recorded with photographs, illustrations and detailed notes. All artifacts collected were prepared for curation and curated at CAS.

\section{Laboratory Methods and Analyses}

All recovered artifacts, faunal remains, and organic and sediment samples were returned from the field to the CAS laboratory. In the lab, all artifacts were washed, categorized, and cataloged. All sediment was washed off of lithic material using water and brushes, whereas fragile material (i.e., faunal remains, pottery, shell) was lightly brushed to remove as much sediment as possible without compromising the condition of the artifact. Cleaned artifacts were then divided into descriptive and analytical categories: metal, glass, ceramic, burned clay, lithics, fire-cracked rock, organic fauna, organic flora, personal items and modern synthetic material. These categorical data, as well as provenience, weight, frequency, and

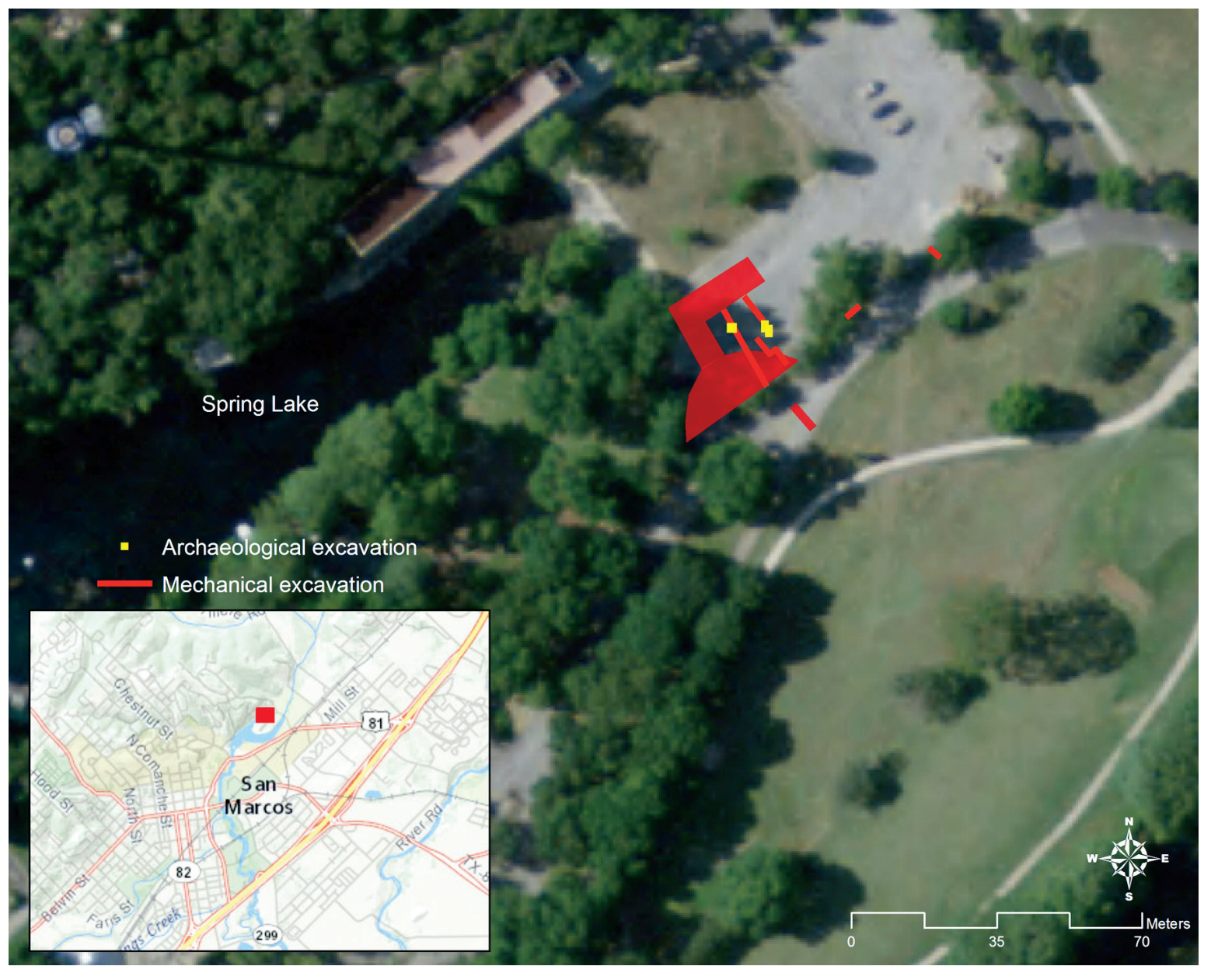

Figure 3-4. Map showing all areas of controlled units and mechanical excavation that were monitored as part of the current undertaking. 


\section{Chapter 3}

brief descriptions, were entered into an analytical and curatorial database. Unique alphanumeric identifiers were assigned to each class from a specific provenience, so as to keep track of artifacts through their processing. Charcoal and bulk sediment samples received the same level of effort in terms of categorization and cataloging, though they were submitted to different and appropriate analyses.

Chapters 4-7 discuss the results of those analyses according to data category: sediment and stratigraphy, radiocarbon dates, faunal remains, and artifacts. The organization of these topics is intended to build toward an integrated understanding of the natural and cultural characteristics of this part of $41 \mathrm{HY} 160$, starting with natural processes and temporal control for the deposit and concluding with the kinds of artifacts that were recovered and their frequencies of occurrence. Because the overall size of the excavated sample is so small, comprising only $6 \mathrm{~m}^{3}$, the focus is on understanding occupational chronology and also on natural and cultural factors in the deposition of these remains. Some aspects of analysis and interpretation are emphasized over others; for example, information about recovered artifacts is largely descriptive and limited to quantification of total recovery. Additionally, priority in the radiocarbon dating was given to understanding the timing of the Calf Creek component in terms of the appearance of bison and related technological and typological developments. To be sure, future analyses could add additional insight into many other, more specific aspects of this overall assemblage. 


\section{Chapter 4 Geoarchaeology}

by David M. Yelacic

Investigations sought to understand the depositional context and integrity of cultural remains in this locale and to provide a tightly controlled chronological model of occupation spanning a period of time represented by approximately three meters of deposition. The north and west walls of the $1 \times 2 \mathrm{~m}$ excavation (Units 3 and 4) were the foci of geoarchaeological sampling and description. The north wall was a one meter wide section, and the west wall exposed a two meter wide profile. Profile illustrations provide a continuous and accurate representation of the entire column of sediment that was encountered. The two walls shared common characteristics, and for this reason the western wall is the profile referred to due to its wider exposure. Samples for quantitative examination of sediment properties were taken from the northwest corner of the unit. The methodology for analyzing these samples is presented below, and profile descriptions follow discussions of methodology.

\section{Sediment Analysis}

Physical properties of the sedimentary matrix were documented from the excavation unit. Bulk sediment samples were collected every $10 \mathrm{~cm}$ in depth, and for each sample, texture (i.e., particle size) and magnetic susceptibility were assessed. Artifacts collected with the bulk sediment samples were recorded as they were encountered through sample processing.

In the field, bulk sediment samples were collected in one-gallon bags, producing more sediment than required to complete the targeted analyses. Unused portions have been archived for possible future study. After being thoroughly mixed, approximately half of each sample was removed for analysis and then weighed. A split of the sample to be analyzed was passed through a $2 \mathrm{~mm}$ sieve to further refine it. The $<2 \mathrm{~mm}$ fraction was set aside for hydrometer method analysis, and the $>2 \mathrm{~mm}$ fraction was processed for sieve method analysis. These two combined methods result in accurate measurements of gravel, sand, silt, and clay proportions of each sample. 


\section{Chapter 4}

When sediment could no longer pass through the $2 \mathrm{~mm}$ sieve using minimal force, the $>2 \mathrm{~mm}$ fraction was mixed into a 5 percent solution of sodium hexametaphosphate in order to break down clay content. After 24 hours of soaking with intermittent agitation, this $>2 \mathrm{~mm}$ fraction was again passed through a $2 \mathrm{~mm}$ screen to isolate coarse fragments, which in this case included gravel and small lithic artifacts. Material separated on the $2 \mathrm{~mm}$ sieve was ovendried at $105^{\circ} \mathrm{C}$ overnight, and then mechanically agitated in nested sieves of 1-phi increments (-5 to -1 phi) for five minutes. Material caught on each screen was then weighed and its mass was recorded.

Approximately $60 \mathrm{~g}$ of $<2 \mathrm{~mm}$ material from each sample was added to $100 \mathrm{~mL}$ of 5 percent sodium hexametaphosphate solution. Samples soaked for a minimum of an hour prior to further processing. Soaked samples were then mixed by a mechanical mixer for five minutes before being diluted by distilled water in a 1-liter hydrometer cylinder. This solution was then manually agitated for one minute before being set on a table and having hydrometer measurements taken at specified intervals (i.e., 1, 3.5, 15, 45, 300, and 1440 minutes). Temperature and hydrometer measurements of $100 \mathrm{~mL}$ of 5 percent sodium hexametaphosphate diluted with distilled water in a hydrometer cylinder were periodically taken for control. Hygroscopic moisture was also corrected by measuring the difference in mass between an un-dried sample and the same sample after oven-drying. Following the last hydrometer reading of each sample, samples were passed through a 4-phi sieve, and the material retained was oven-dried overnight. This material was then mechanically agitated for five minutes in nested sieves spanning zero to four phi.

Measurements of magnetic susceptibility were taken on small, oven-dried splits of the $<2 \mathrm{~mm}$ material from each bulk sample. These small samples were packed into $2.5 \mathrm{~cm}$ plastic cubes and then weighed. Two measurements of low-frequency and two measurements of highfrequency were taken at the 0.1 level using a Bartington MS2 meter and an MS2b sensor. Mass corrected susceptibility $(\chi)$ and frequency dependent $\left(\chi_{F D} \%\right)$ were calculated from the lowand high-frequency measurements using the following equations:

$$
\begin{gathered}
\chi=\chi_{L F} /\left(\frac{\text { sample mass }}{10}\right) \\
\chi_{F D} \%=100 *\left(\frac{\chi_{L F}-\chi_{H F}}{\chi_{L F}}\right)
\end{gathered}
$$

where $\chi$ is the magnetic susceptibility measurement, ${ }_{L F}$ is low frequency readings, ${ }_{H F}$ is high frequency readings, and ${ }_{F D}$ is the frequency dependent calculation. Sample mass is measured in grams, and it is divided by $10 \mathrm{~g}$, for which the instrument has been calibrated. Mass corrected low frequency readings analyze the total amount of magnetic material contained within the sample, and the frequency dependent calculation indicates the amount of superfine magnetic material, which is biogenic in origin. 


\section{Profile Descriptions}

Nine zones, representing distinct layers of sediments and/or soils or combinations thereof, spanned the profile (Figure 4-1). At the top of the profile exposure, Zone I, is composed of very dark gray clay lying directly beneath parking lot base. Zone 1 contains artifacts, but it also contains gravels associated with parking lot construction. In the north wall, the base of Zone I appears to have a more red color that is not quite apparent in the western wall profile. Zone II has an abrupt smooth contact with Zone I, and is dark brown silty clay that contains a moderate abundance of snail shells, burned rocks, and lithic artifacts. Discontinuous clay coats

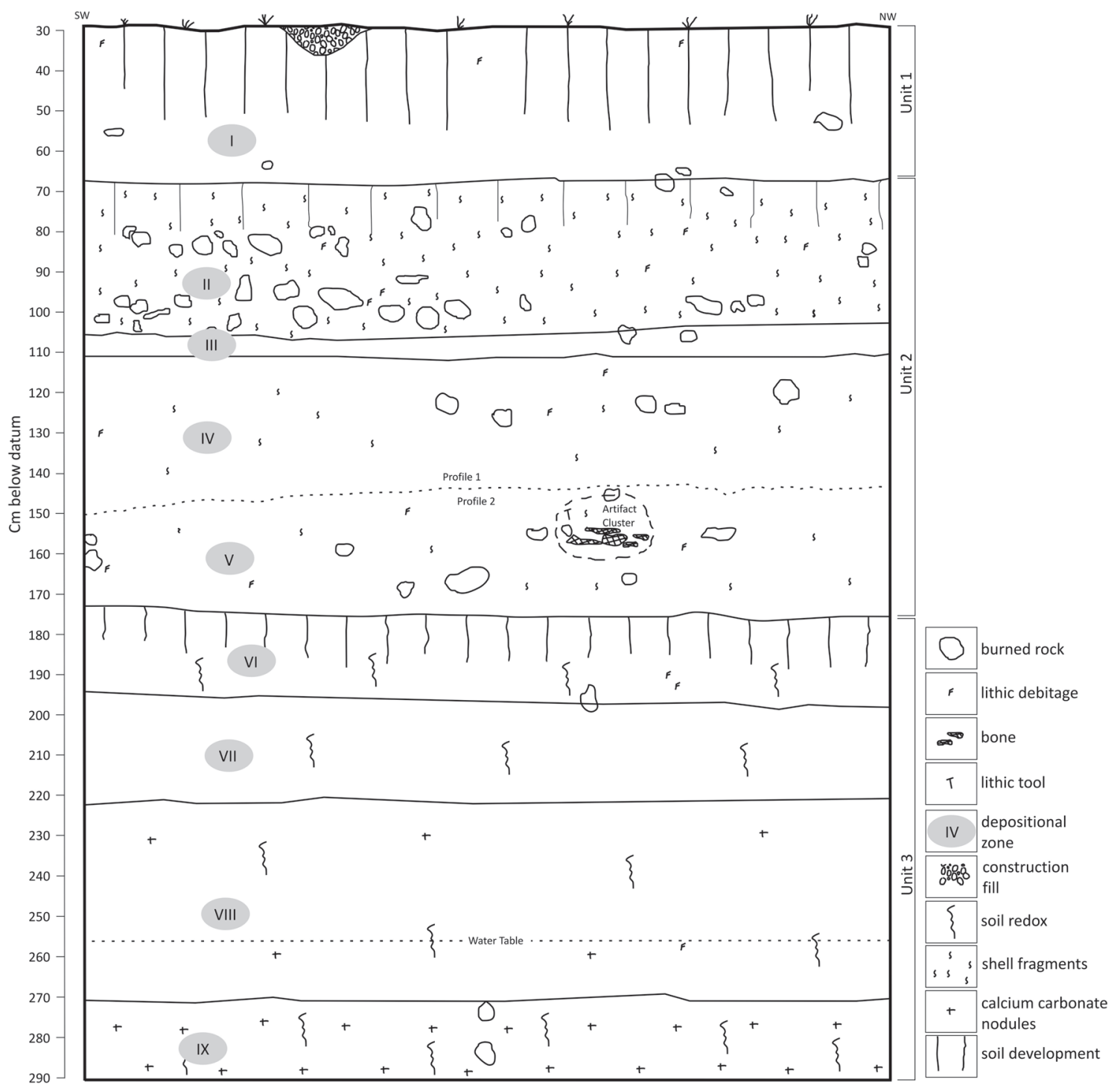

Figure 4-1. Technical profile of western wall of Units 3 and 4. Depositional zones are discussed below. 


\section{Chapter 4}

cover ped faces and coarse fragments in Zone II, which has an abrupt, smooth lower boundary. Below Zone II is Zone III, a relatively thin $(6 \mathrm{~cm})$ dark reddish brown clay that contains very little burned rock. Zone III, however, does contain artifacts. The boundary between Zone III and IV is clear and smooth, and Zone IV is similar in appearance to Zone II, but with a slightly reduced frequency of artifacts and snail shells. Zone IV is dark yellowish brown clay and contains scattered burned rocks, other lithic artifacts, and snail shells. The lower boundary of Zone IV is clear and smooth, overlaying Zone V, which is dark grayish brown to brown silty clay with abundant snail shells, burned rock, other lithic artifacts, and faunal remains. Zone IV and $\mathrm{V}$ were separated only by the phase of mechanical excavation described in the previous chapter, and the two probably represent the same stratigraphic unit. Zone V has an abrupt, irregular contact with Zone VI below. This boundary signifies a change between stratigraphic layers, and is confirmed by the drastically diminished artifact frequency at this point. Zone VI consists of dark brown silty clay and contains dark grayish brown mottles. Below Zone VI, Zones VII through IX are all bounded by gradual, smooth transitions, contain the same dark grayish brown mottles, have clay coats on ped faces, and contain nodular calcium carbonate. The ground water table was encountered in Zone VIII at approximately $245 \mathrm{~cm}$ below surface.

In terms of aggregating zones into depositional units, which represent periods of deposition bound by periods of erosion and/or surface stability, there are three distinguishable units. The lowest approximately 1.25 meters, Zones VI through IX, compose the oldest depositional unit capped by a buried, likely truncated and/or turbated A horizon. The lowest observed portion of this unit, limited by depth of excavation, was a very damp to completely saturated Bk horizon containing common, small calcium carbonate nodules and redoximorphic features. Accurately assessing accurate rates of aggradation during this period/depositional unit is not possible based on recovered materials. There is a lack of preserved organic remains suitable for dating, and the recovered Early Archaic diagnostic material from lowermost levels does not have the temporal resolution necessary to model depositional rates. Nevertheless, based on the recovery of a Gower point base from level 27 and radiocarbon dates from levels 16 and 17 (see below), it is estimated that large quantities of sediments were deposited over this part of the Spring Lake site in a fairly short period of time compared with upper stratigraphic units. This rate is likely to far exceed a meter of sediment over a thousand-year-long period of time.

Distinction between the upper two units is dependent upon the color contrast among Zones I and II, as noted above. The middle depositional unit is topped by a buried, disturbed A horizon. This unit contains vestiges of the Early Archaic at the bottom and Late Archaic at the top, but the upper two-thirds (i.e., Zones II through IV) contain a mixture of Middle to Late Archaic projectile points. These temporally diagnostic artifacts representing approximately four millennia are situated within 100 centimeters vertically, which suggests a much slower rate of aggradation than for the first stratigraphic unit.

The uppermost unit, composed of Zone I, was truncated by the parking lot that was removed to accommodate the ticket kiosk construction. This unit is the thinnest of the three, 
and it contains artifacts from the Late Archaic to the Late Prehistoric, encountered in correct stratigraphic order. Being the thinnest and containing artifacts representing approximately 2500 years of time, at least, it is also the lowest rate of deposition at this portion of $41 \mathrm{HY} 160$.

\section{Particle Size and Magnetic Susceptibility}

Particle size analysis, which quantifies texture, can help to support field-based interpretations and/or elucidate minute, unobserved changes in the sediment column. Results of hydrometer method analysis, described above, show that the sediment is predominantly clay with slight variations in the amount of particle sizes (i.e., gravel, sand, silt, and clay). From the bottom of the profile upwards, the quantity of sand steadily decreases while clay increases, albeit slightly. The proportion of sand decreases from approximately 10 to 2.5 percent, whereas clay increases from approximately 48 to 56 percent. Proportions of silt vary less than sand and clay, but there are statistically significant differences in the proportions of sand, silt, and clay by depositional unit. Examination of the particle sizes by unit using a Kruskal-Wallis test, a nonparametric analysis of variance, indicates differences that are significant $(p<0.05)$. Results of the same metric used to examine mean and standard deviation of particle sizes indicate they are not statistically significant, and therefore the sedimentary material is consistently sorted. This is all to say that there are differences in the proportions of sand, silt, and clay among the three depositional units (Figure 4-2).

Considering mixed artifacts and pedogenic processes, the origin of textural changes can be complex. Magnetic susceptibility analysis, specifically the frequency dependent measurement, can be used to identify soil development. Mass specific low frequency measurements (Xlf) examine the total amount of magnetic material, which includes anthropogenic matter (i.e., cooking-related burned rock debris). Results of mass

specific low frequency measurements agreeably peak with increases in evidence of hot rock cooking in Zone II and again, to a lesser degree, in Zone V. Mass specific frequency dependent results generally diminish from the top of the profile down. There is a peak at the top of Zone II and another near the top of Zone VI. These trends correspond with the posited depositional unit transitions and formerly stable surfaces and buried A horizons. Although there appears to be a considerable amount of variation, this variation might be attributed to bioturbation (Singer et al. 1996) or even argilliturbation. The curve of the mass specific low frequency readings (i.e., peaks diminishing at a near-steady rate) appears to support the hypothesis of vertical disturbance, albeit in unknown amounts. Nonetheless, major trends in the magnetic susceptibility data support the conclusion that natural and cultural depositional units are generally in good order and minimally disturbed, despite the potential vertical movement of fine magnetic particles. 


\section{Chapter 4}

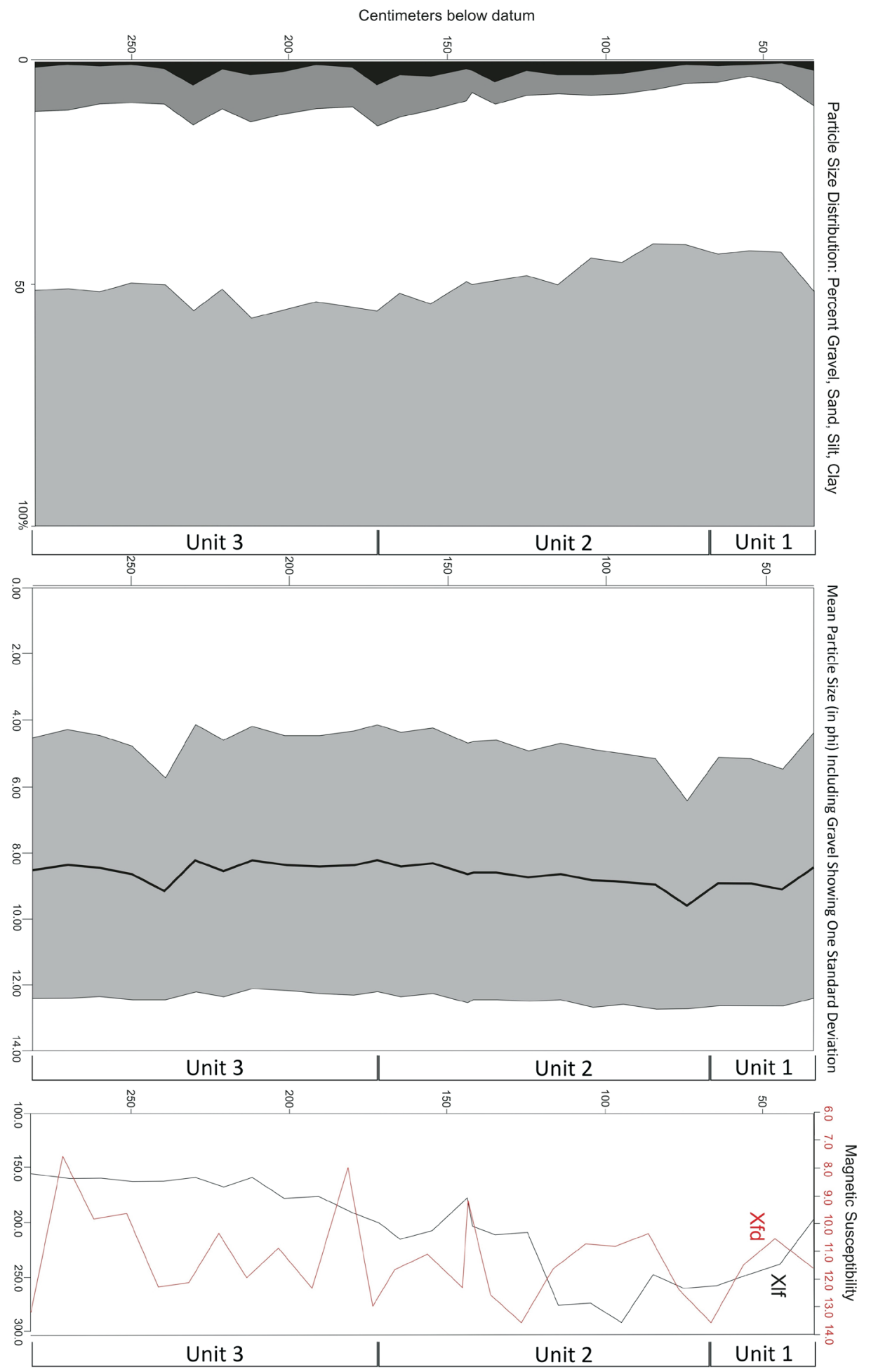

Figure 4-2. Results of particle size and magnetic susceptibility analysis. 


\section{Chapter 5 Radiocarbon Dates and Dating}

by Jon C. Lohse

Chronometric control for stratigraphy exposed in these excavations was achieved primarily by direct dates on archaeological bone material. Complementary information comes from the stratigraphic ordering of temporally diagnostic artifact types, particularly stylisticallydistinctive projectile points. Many point specimens, however, proved either to be out of their expected locations in relation to other well-dated points, or did not conform to defined typological categories. Consequently, information from diagnostic artifacts complements the absolute dates by filling in portions of the excavated sequence for which no dates are available, and also by indicating sections of the stratigraphy that are compressed or perhaps altogether mixed. Typological data are presented in Chapter 7, together with all other lithic and non-lithic artifacts.

\section{Presentation of Radiocarbon Results}

A total of 15 radiocarbon assays were run on material recovered during excavations and monitoring at the Ticket Kiosk. Of these, 14 are animal bone recovered from Units 3 and 4 (Table $5-1)$. The last date is from the burial that was exposed and removed during the monitoring phase of investigations. No charcoal was submitted for dating in this phase of the analysis. The first 14 dates provide a relatively complete understanding of the ages represented in this deposit, and also of the overall stratigraphic integrity and nature of cultural deposits in this area of 41HY160. These discussions focus on the assays from Units 3 and 4 .

Bone was selected as the medium for dating for several reasons. First, it allows this study to focus on the relationship between bison presence and exploitation and the appearance of technologically-distinctive artifact styles, specifically including projectile points of the Bell and Andice (Calf Creek) types. This study builds on and continues ongoing CAS research into regional bison chronologies during the middle to late Holocene for the San Marcos area of Central Texas (Lohse et al. 2012). Second, carbonized plant remains, like very small 
magnetized particles discussed previously, have the potential to be translocated, or "move" within an otherwise intact deposit more easily than bone, given the larger size of most bone specimens considered for dating. Compounding this issue is the possibility for old wood to be introduced into archaeological matrices through scavenging on the landscape. Both factors can skew the results of wood carbon dates. Third, the development and application of specialized pretreatment processes and protocols (called XAD purification), combined with high precision accelerator mass spectrometry (AMS) dating has considerably improved the accuracy and reliability of bone dates. CAS has previously submitted for XAD pretreatment and AMS dating a number of animal bone samples, specifically bison, from Spring Lake and nearby sites, and the current study fits neatly into this growing record.

While the priority in the current study was to increase the number of bison samples, particularly those from the Calf Creek component that have been dated from Spring Lake, it was also important to date parts of the sequence for which bison is not available. The first step in selecting samples to submit for dating involved scanning the faunal assemblage to determine the distribution of bison remains to be evaluated for submission $(n=9)$. Next, some additional samples $(n=5)$ were selected from proveniences that complemented those containing bison. Important in this round of sample selection were achieving a date from the lowest possible level, and closely bracketing the Calf Creek component with AMS dates. Given poor bone preservation at lower depths, the lowest viable sample that could be dated was from level 17 of Unit 4. This means that an additional meter of excavated deposits remains undated by absolute means. Two of the samples were returned with dates that are stratigraphically out of proper sequence. These assays, and all other results, are discussed in detail below.

Once samples were selected, they were submitted to the Archaeological Dating Laboratory at Pennsylvania State University, to be processed using the XAD purification method. Treated target samples were then submitted to the Accelerator Mass Spectrometry laboratory at the University of California at Irvine. After target samples were counted by AMS, measured radiocarbon ages including a standard deviation were returned to CAS via Penn State. In addition to field sample numbers, the UC Irvine facility assigned lab numbers to each sample according to sequence; these UCIAMS numbers are used to refer to each specimen/date, below.

\section{XAD Purification and the Reliability of Bone Dates*}

Previous work with animal bone has identified some issues that can undermine the reliability of resulting dates. These issues have to do with degree of preservation of datable components, and the replacement of original organic compounds with extraneous carbon molecules from surrounding site matrix. In order to address these issues, various pretreatment techniques or protocols have been developed and applied as a way to ensure the reliability of bone dates. One method, called XAD purification, was applied to samples recovered during this excavation.

*The assistance provided by Brendan J. Culleton in the section about XAD purification was greatly appreciated. 
As noted, exogenous or highly degraded carbon can present serious problems for reliably dating archaeological bone material (see Hedges and Van Klinken 1992). Two modern approaches to remove contaminating foreign carbon from bone collagen samples have been developed over the last two decades in order to minimize or altogether avoid these problems. One is called ultrafiltration (Brown et al. 1988) and the other is called XAD purification (Stafford et al. 1988, 1991). A conceptual review of bone dating methods is helpful in understanding the XAD purification technique.

Collagen, the protein that provides the organic matrix in which bone is mineralized, comprises roughly 20 percent of dry bone by weight, and is the source of carbon used in accelerator mass spectrometer (AMS) radiocarbon dating. Since the early decades of radiocarbon dating collagen has been isolated from the inorganic mineral portion of bone by demineralization in dilute acid or, less commonly, by chelation or enzyme digestion (e.g., Berger et al. 1964). Typically the collagen is then treated with a dilute base (e.g., $0.1 \mathrm{~N} \mathrm{NaOH}$ or $\mathrm{KOH}$ ) to extract soil humic and fulvic acids, which are organic compounds identified as the main sources of exogenous carbon contamination in archaeological and paleontological bone. Using traditional procedures (e.g, Longin 1971), extracted collagen is then gelatinized in a heated weak $\mathrm{HCl}$ for several hours, lyophilized, and then combusted to produce sample $\mathrm{CO} 2$ for AMS 14C dating.

Stafford et al. (1988, 1991) have argued, however, that gelatinization as described above is not adequate to disassociate all humic and fulvic acids bound to collagen (contra Longin 1971). Their concern is that, if all exogenous humic and fulvic acids are not removed, then it may be possible for these foreign contaminants to cross-bind smaller degraded collagen chains into long chains that also contain exogenous carbon. Using the ultrafiltration method, the gelatinized target sample is passed through a Vivascience 15R concentrator (ultrafilter) in order to remove remaining foreign contaminants (Bronk Ramsey et al. 2004). These ultrafilters, however, are treated with a ${ }^{14} \mathrm{C}$-enriched glycerin coating that, if not completely removed, can add rather than remove contaminants to the target sample (Huls et al. 2007, 2009).

In response to these complex concerns, Stafford et al. $(1988,1991)$ recommended an approach called XAD purification for pretreating bone specimens. This approach to eliminating contaminants breaks the collagen down to individual amino acids by hydrolysis in strong $(6 \mathrm{~N})$ $\mathrm{HCl}$, thereby releasing humic and fulvic acids into solution. The hydrolyzate is then passed through a styrene-divinylbenzene (XAD) resin, which is chemically inert but highly adsorptive of ionic contaminants while allowing the purified amino acids to pass through. After drying the hydrolyzate the sample is combusted following standard procedures and sample CO2 is used for AMS 14C dating. The result is that bone dates are more reliable in terms of providing accurate and precise age estimations for the archaeological samples in question. 


\section{Problematic Dates}

Two of the dates in this assemblage, UCIAMS-106466 and UCIAMS-106470, are out of order in relation to their stratigraphic position. UCIAMS-106470, a bison sample, returned a date of $2415 \pm 20$ radiocarbon years before present (RCYBP), while UCIAMS-106466, an antelope phalanx, is associated with a date of $1995 \pm 20$ RCYBP. The date of the bison specimen indicates that the bone fragment was probably originally recovered from around levels 6 or 7 , while the date of the antelope phalanx suggests an original provenience of level 6 or higher.

Among the 14 dates from Units 3 and 4, these two out-of-place dates are concerning insofar as they indicate some disturbance in the site deposits. However, we believe they are the result of handling and processing errors that were made in the CAS laboratory. Once excavated, all sediments were transported from the field to be water-screened outside the CAS building on the Texas State main campus. We suspect that these two specimens were removed from their original proveniences at some point during the screening or laboratory process, and became associated with incorrect contexts.

Reassigning UCIAMS-106470, the bison date, to level 6 or level 7 is easily done based on the closeness of this age $(2415 \pm 20 \mathrm{RCYBP})$ with other bison dates from those levels. Our earlier work directly dating bison has demonstrated three closely-spaced Late Archaic intervals of bison exploitation in the San Marcos general region (see Figure 2-6), and the date for this specimen corresponds quite closely with the three other bison dates from Units 3 and 4 , levels 6 and 7.

Reconstructing the original provenience of UCIAMS-106466, however, is more difficult. Based on the date alone, the sample should have come from slightly above the level 6-7 zone. However, other dates from this depth clearly indicate that sediments are mildly compressed at this elevation. Sample UCIAMS-106463 dates to $515 \pm 15$ RCYBP while two samples (UCIAMS-106464 and UCIAMS-106465) are almost 2,000 years older than this sample but are only $10 \mathrm{~cm}$ lower in elevation. This compression is clearly indicated by the two samples UCIAMS-106471 and UCIAMS-106472 (2490 \pm 15 and $3000 \pm 20$ RCYBP, respectively) that come from the same level (7) in Unit 4. Based on the close proximity in depth of this handful of dates that range from $515 \pm 15$ in level 5 to $3000 \pm 20$ in level 7, it is possible that UCIAMS-106466 could have originally come from anywhere in this part of the unit. It is even possible that the bone specimen is not out of place at all but, rather, is indicates that, contrary to our initial assumptions about the reliability of bone in archaeological matrices, some movement of faunal material has occurred in this part of the deposit.

Based on the respective ages of the two problematic dates and their locations within the stratigraphic sequence at the ticket kiosk excavation, it is felt that the integrity of the Calf Creek zone is not compromised. Rather, lab error resulted in a later date being incorrectly associated with this part of the deposit. Cultural deposits between approximately levels 5 through 7 , however, appear to be at least slightly compressed and perhaps mildly mixed, although otherwise are mostly intact. 


\section{Discussion of Radiocarbon Results}

Overall, the 15 radiocarbon dates provide a reliable indication of the general age range of deposits represented in Units 3 and 4 (Figure 5-1). An important exception to this understanding is that, as a result of poor preservation at lower elevations, no material suitable for dating was available from below level 17. This means that the final meter or so of excavations remains poorly dated, with the only bit of temporal data coming from the base of an apparent Gower point from level 27 (see below). Of the 15 dates, one (UCIAMS-111181) came from the human burial recovered during utility trench monitoring; this date is discussed in Chapter 5 along with observations about these important remains and other results from the monitoring program.

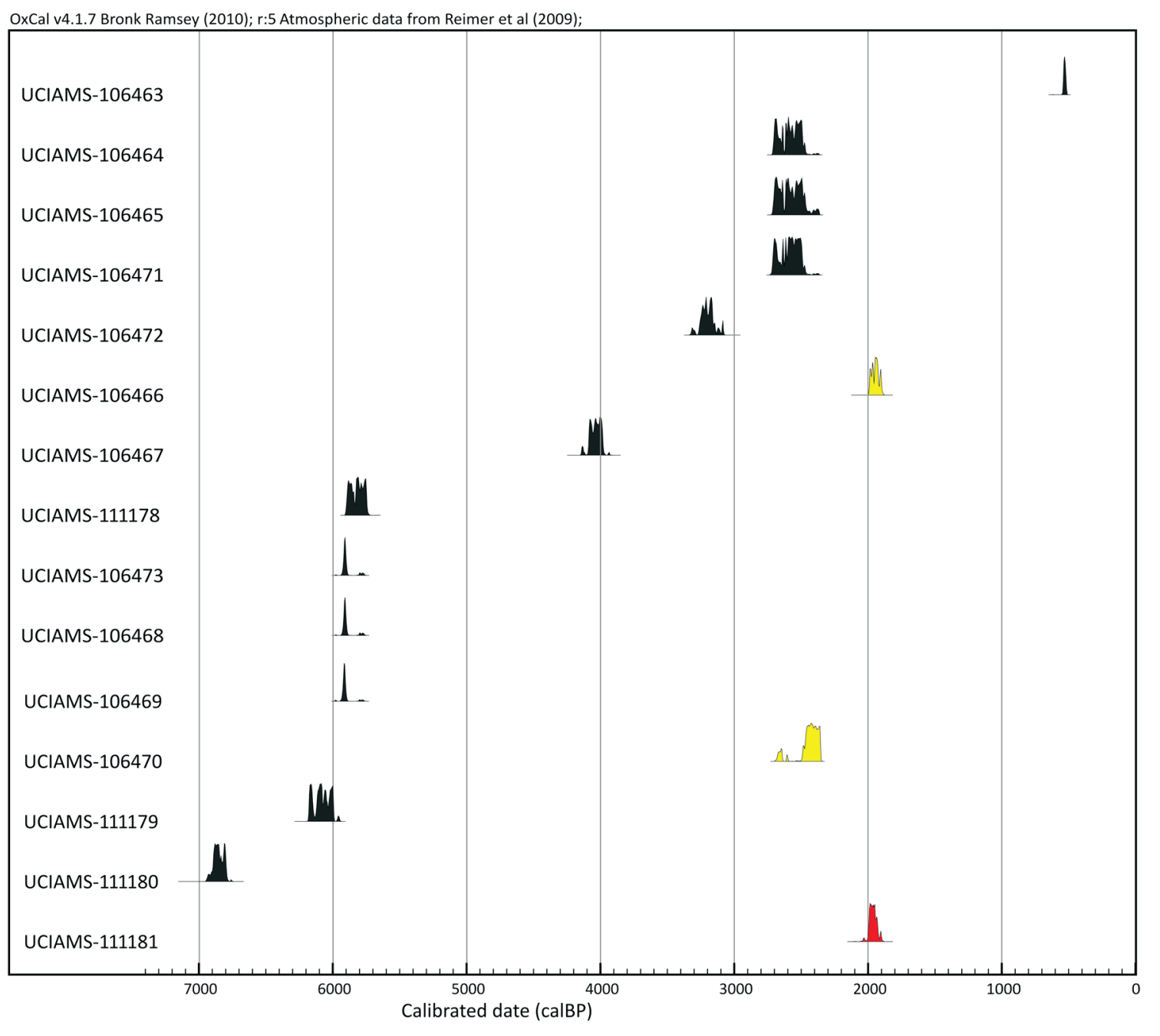

Figure 5-1. Results of AMS radiocarbon dates from the Ticket Kiosk excavation in calibrated years before present. Dates in yellow are the two problematic ones and the one in red is the burial. All other results are in perfect order by depth. 


\section{Chapter 5}

The 12 AMS dates that were recovered in proper order with respect to their ages provide a solid basis for reconstructing the age of these deposits, and for making some preliminary interpretations about this part of 41HY160 (the two problematic dates are not discussed). Because nine of the 14 dates from the block are on bison remains, many of these interpretations revolve around issues of occupation and site formation that involve the presence and exploitation of bison. In spite of this bias, some overall understandings are possible. In the following discussions, all dates are considered at their two-sigma calibrated distributions in years before present (cal B.P.). For the sake of simplicity, brief non-contiguous intervals in the calibrated probability distributions are overlooked, and dates are discussed from their maximum to minimum probabilities. Sample numbers are included in parentheses so that these discussions can be referenced to Table 5-1.

The uppermost date in the sequence, UCIAMS-106463, dates to 544-514 cal B.P., but is

only $10 \mathrm{~cm}$ higher than the next two, UCIAMS-106464 and -106465, which together span from 2714-2372 cal B.P. The difference between these ages, approximately 1800-2300 years, in only $10 \mathrm{~cm}$ of sediment indicates that this portion of the deposit is either mixed, with datable materials having been relocated from their original position, is compressed, with minimal sediment deposition occurring over this span of time, or both. As a result, very little distinction seems possible in this part of the site in terms of assigning non-diagnostic tool forms, or artifact or faunal recoveries to the Late Prehistoric or Late Archaic. Rather, such trends are more appropriately considered at coarse temporal scales of resolution. We avoid making any interpretive statements whatsoever regarding significant cultural changes that may have occurred during or between these periods.

The next two dates in the sequence, UCIAMS-106471 and -106472, are only $10 \mathrm{~cm}$ below UCIAMS-106464 and -106465, but represent another apparently missing or compressed span of time. This interval is only on the order of approximately 500 years, but nonetheless poses interpretive challenges to recognizing or postulating meaningful cultural differences between these phases of the Late Archaic. Because these two Late Archaic assays are both on bison, as are the two in level 6, it can be said that sediments found in this part of the deposit date to the first two Late Archaic periods of bison exploitation discussed in Chapter 2 (see Figure 2-6).

The next date in the sequence, UCIAMS-106467, is important for filling in the poorlydated portion of the deposit between levels 7 and 11, which lies just above what is considered to be the Calf Creek component (see below). Without corroborating assays, this single date, 4140-3980 cal B.P., may not carry a great deal of significance. It appears, however, to be approximately equidistant, age-wise, between the next highest and next lowest date, suggesting that this part of the deposit is well-ordered and reasonably intact.

Starting with UCIAMS-111178, the next five reliable assays were submitted with the goal of dating the bison-bearing component associated with Calf Creek materials. Sample UCIAMS-111178 was selected from levels from which no bison was present, while UCIAMS-111179 was taken from below the bison zone. The three assays from levels 13 and 14, 
UCIAMS-106473, -106468, and -106469, are all virtually identical, covering a 169-year interval spanning from 5936-5767 cal B.P. Sample UCIAMS-111178, taken from above this zone, is also similar to these three dates. Taken together, the results of these four assays (excluding UCIAMS-111179) indicate that sediments from levels 11 through 14 seem to have been deposited over a brief period of time, perhaps only 189 years (based on the difference between the oldest and youngest probable distributions among all five assays). Given the absence of bison remains associated with UCIAMS-111179 (6181-5992 cal B.P.), it is argued that the Calf Creek period, at least at this locale, had ended by around $6000 \mathrm{cal}$ B.P. if not earlier. Based on these dates, a conservative estimate for the duration of Calf Creek could reasonably be 5750$6000 \mathrm{cal}$ B.P., and it is likely that this period covered an even shorter span of time.

The final assay, UCIAMS-111180, simply extends the portion of this deposit for which absolute temporal control exists another 10 or so centimeters in depth. The fact that this date is 650-750 years older than UCIAMS-111179 suggests that sediment deposition rates were considerably higher than what characterizes the Calf Creek component of the site. Taken together and viewed in the context of the stratigraphic discussions, above, the overall sequence is remarkably intact, seems to contain elements or components that have high degrees of temporal clarity, and reveals a great deal of important information about the prehistoric occupation and site formation processes in this area of the Spring Lake site, particularly for what is identified as the Calf Creek component (Figure 5-2). 


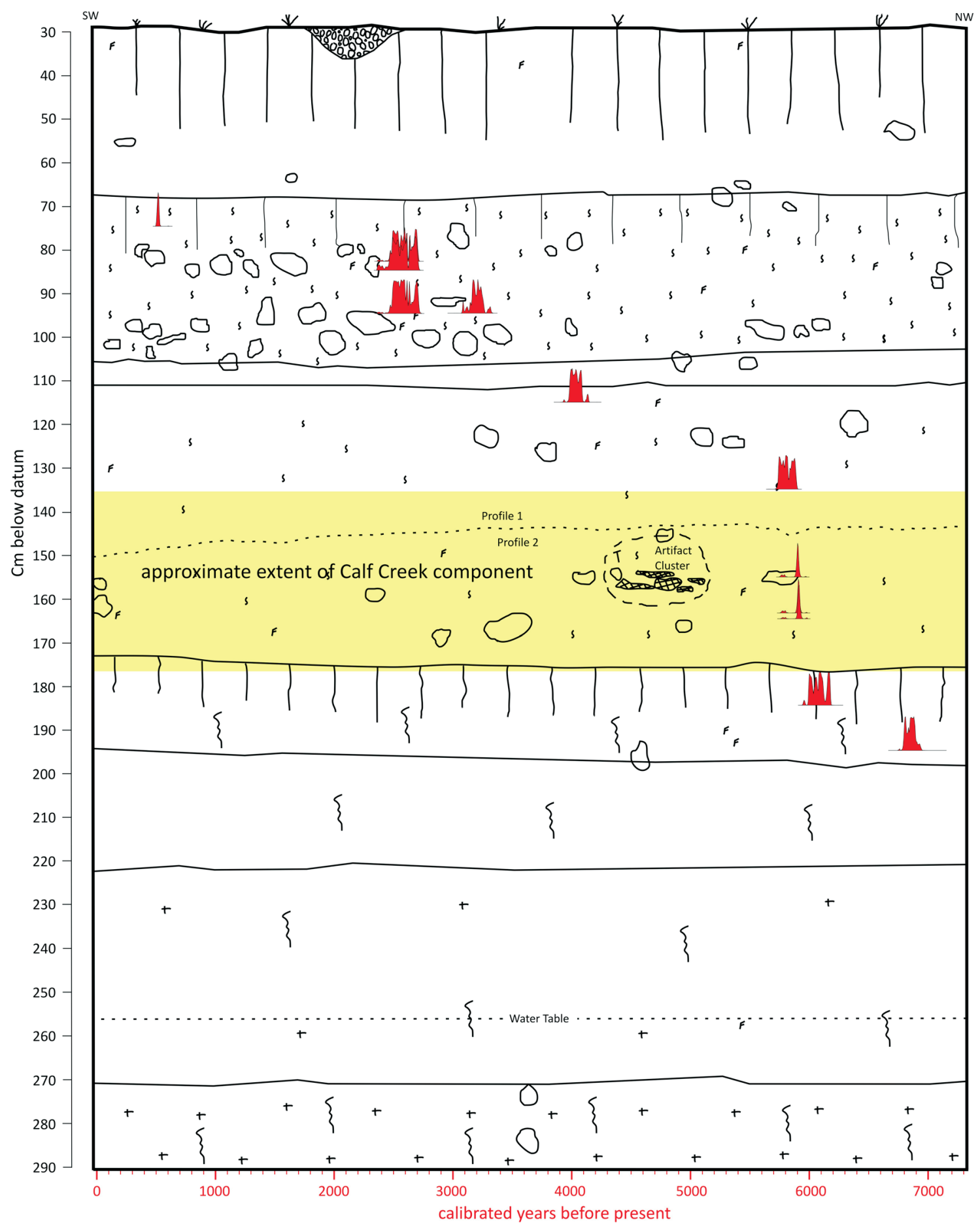

Figure 5-2. Calibrated AMS dates (excluding the two that were out of order) plotted on technical profile of excavation units. 


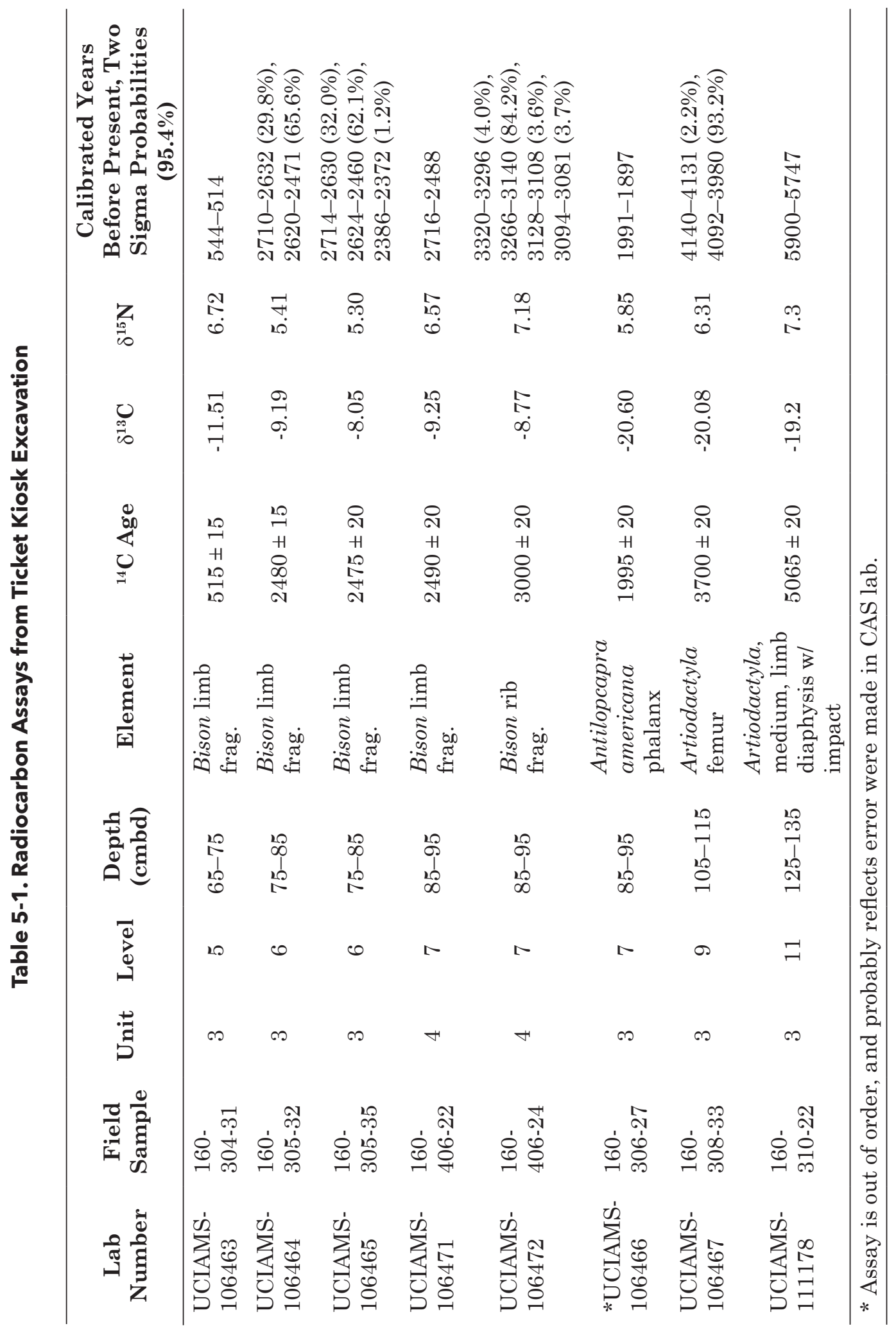




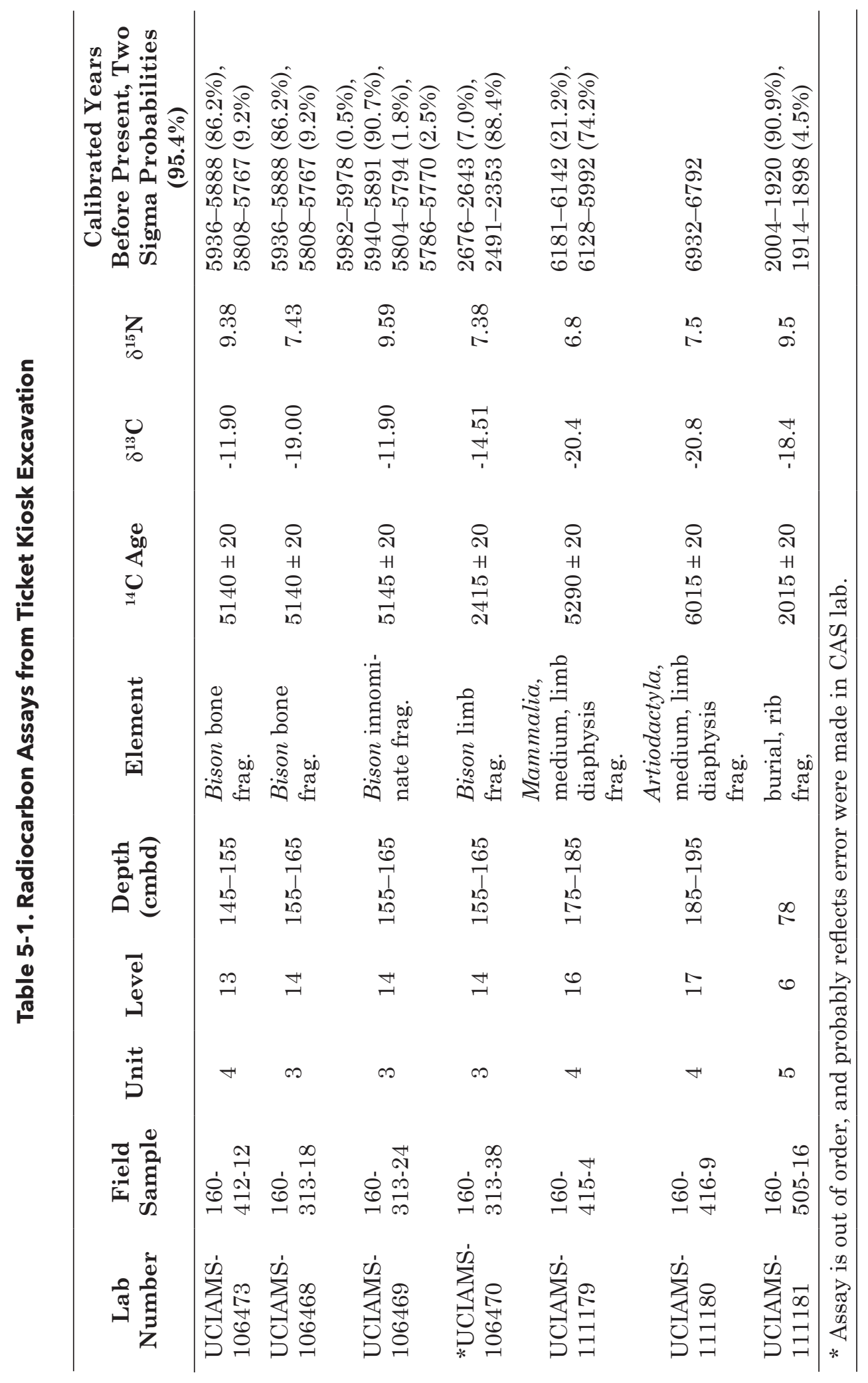




\section{Chapter 6 Faunal Remains}

by Cinda L. Timperly

Faunal material was recovered by means of visual inspection of matrix in the unit, from screening excavated matrix, and during laboratory sorting of screened material. Material was recovered from Units 3 and 4, and from areas of mechanical excavation that were monitored. The portion of the assemblage deriving from Units 3 and 4 was collected under systematic conditions, and may accurately reflect the general trends that define zooarchaeological remains at Spring Lake for the time periods represented in this sample. Although a small amount of material was recovered from monitoring, this write up focuses exclusively on the remains recovered by hand excavation. All material recovered from Units 3 and 4 was examined (Units 1 and 2 were discounted once it was discovered that these contained disturbed deposits). The final sample size from Units 3 and 4 includes an initial count of 2600 specimens and mass of $1472.7 \mathrm{~g}$. Some unit-levels, particularly toward the bottom of the excavation, did not contain any material. Some minor discrepancies in count and mass values are the result of specimens that mend on fresh breaks being counted upon analysis as one item rather than multiple items.

This $1 \times 2 \mathrm{~m}$ unit provides a controlled sample of stratified deposits spanning the time from Late Prehistoric Toyah more or less continuously well into the Early Archaic. The sequence is securely dated by radiocarbon, and important supplementary information comes in the form of temporally diagnostic projectile points (see Chapter 7). Poor preservation conditions below approximately level 17 (185-195 cm below datum) mean that chronological control for the lower levels (18-25) is moderate to poor, while it can be considered excellent for the upper parts of the deposit.

The goals of the faunal analysis were to taxonomically identify the material recovered from this excavation, and to assess trends in the availability of different species over time. Although the sample is relatively small, some discussion is possible concerning changes through time in the number and diversity of taxa present. These changes can help characterize resource subsistence strategies that were implemented by the prehistoric occupants of Spring Lake. 
Additionally, they can help scholars reconstruct aspects of the environment at this locale over a period of approximately 7000 years. The analyzed portion of the recovered assemblage is listed in Table 6-1.

Table 6-1. Faunal Remains by Level and Elevation (recoveries from Units $\mathbf{3}$ and $\mathbf{4}$ are combined)

\begin{tabular}{|c|c|c|c|c|}
\hline $\begin{array}{c}\text { Level } \\
\text { (Elevation, } \\
\text { cmbd) }\end{array}$ & Taxon and Count & $\begin{array}{l}\text { Final Count* } \\
(\mathrm{N}=\text { MNISP) }\end{array}$ & $\begin{array}{c}\text { Final } \\
\text { Mass } \\
\text { (grams) }\end{array}$ & $\begin{array}{l}\text { Rich- } \\
\text { ness*** }\end{array}$ \\
\hline $1(25-35)$ & $\begin{array}{l}1 \text { Serpentes; } 37 \text { Mammalia; } 1 \text { Mammalia, } \\
\text { medium; } 1 \text { Ruminant, large; } 2 \text { Bovidae }\end{array}$ & 42 & 15.6 & 5 \\
\hline $2(35-45)$ & $\begin{array}{l}1 \text { Osteichthyes; } 3 \text { Testudines; } 1 \text { Serpentes; } \\
2 \text { Aves(?); } 91 \text { Mammalia; } 1 \text { Sigmodon; } 7 \\
\text { Mammalia, small; } 13 \text { Mammalia, medium; } \\
2 \text { Artiodactyla; } 1 \text { Artiodactyla, medium; } 2 \\
\text { Odocoileus; } 2 \text { Bovidae }\end{array}$ & 126 & 45.2 & 11 \\
\hline $3(45-55)$ & $\begin{array}{l}2 \text { Vertebrata; } 3 \text { Osteichthyes; } 2 \text { Serpentes; } \\
7 \text { Testudines; } 68 \text { Mammalia; } 10 \text { Mammalia, } \\
\text { small; } 9 \text { Mammalia, medium; } 2 \text { Odocoileus; } \\
1 \text { Bovidae }\end{array}$ & 104 & 32.4 & 10 \\
\hline $4(55-65)$ & $\begin{array}{l}2 \text { Vertebrata; } 4 \text { Osteichthyes; } 1 \text { Anura; } 14 \\
\text { Testudines; } 1 \text { Serpentes; } 1 \text { Aves; } 88 \text { Mam- } \\
\text { malia; } 12 \text { Mammalia, small; } 3 \text { Sylvilagus; } 1 \\
\text { cf. Sylvilagus; } 1 \text { Rodentia; } 2 \text { cf. Sigmodon; } 2 \\
\text { cf. Geomys; } 1 \text { Canis; } 22 \text { Mammalia, medium; } \\
5 \text { Artiodactyla; } 8 \text { Artiodactyla, medium; } 2 \\
\text { Odocoileus; } 1 \text { Mammalia, medium to large; } \\
2 \text { Bison; } 4 \text { Mammalia, fetal/juvenile }\end{array}$ & 176 & 81.6 & 20 \\
\hline $5(65-75)$ & $\begin{array}{l}2 \text { Vertebrata; } 1 \text { Osteichthyes; } 8 \text { Testudines; } \\
1 \text { Trionychidae; } 90 \text { Mammalia; } 24 \text { Mam- } \\
\text { malia, small; } 2 \text { Sylvilagus; } 1 \text { cf. Lepus; } 1 \text { Ro- } \\
\text { dentia; } 1 \text { Neotoma; } 38 \text { Mammalia, medium; } \\
\text { 10 Artiodactyla, medium; } 2 \text { Mammalia, me- } \\
\text { dium to large; } 4 \text { Mammalia, fetal/juvenile }\end{array}$ & 186 & 75.9 & 13 \\
\hline $6(75-85)$ & $\begin{array}{l}1 \text { Anura; } 5 \text { Testudines; } 1 \text { Serpentes; } 67 \\
\text { Mammalia; } 14 \text { Mammalia, small; } 1 \text { Carniv- } \\
\text { ora; } 51 \text { Mammalia, medium; } 3 \text { Artiodactyla; } \\
6 \text { Artiodactyla, medium; } 6 \text { Odocoileus; } 1 \text { An- } \\
\text { tilocapra americana; } 2 \text { Mammalia, medium } \\
\text { to large; } 6 \text { Bison; } 6 \text { Mammalia, fetal/juvenile }\end{array}$ & 170 & 115.9 & 15 \\
\hline
\end{tabular}


Table 6-1. Faunal Remains by Level and Elevation (recoveries from Units $\mathbf{3}$ and $\mathbf{4}$ are combined)

\begin{tabular}{|c|c|c|c|c|}
\hline $\begin{array}{c}\text { Level } \\
\text { (Elevation, } \\
\text { cmbd) }\end{array}$ & Taxon and Count & $\begin{array}{l}\text { Final Count* } \\
\text { (N = MNISP) }\end{array}$ & $\begin{array}{c}\text { Final } \\
\text { Mass } \\
\text { (grams) }\end{array}$ & $\begin{array}{l}\text { Rich- } \\
\text { ness*** }\end{array}$ \\
\hline 7 (85-95) & $\begin{array}{l}1 \text { Anura; } 10 \text { Testudines; } 1 \text { Serpentes; } 1 \\
\text { Aves; } 90 \text { Mammalia; } 17 \text { Mammalia, small; } \\
3 \text { Rodentia; } 1 \text { Geomyidae; } 44 \text { Mammalia, } \\
\text { medium; } 1 \text { Artiodactyla; } 1 \text { Artiodactyla, } \\
\text { hypsodont; } 11 \text { Artiodactyla, medium; } 3 \text { Anti- } \\
\text { locapra americana; } 3 \text { Odocoileus; } 2 \text { Bison; } 6 \\
\text { Mammalia, fetal/juvenile }\end{array}$ & 195 & 131.2 & 14 \\
\hline $8(95-105)$ & $\begin{array}{l}1 \text { Vertebrata; } 2 \text { Osteichthyes; } 1 \text { Anura; } 9 \\
\text { Testudines; } 52 \text { Mammalia; } 41 \text { Mammalia, } \\
\text { small; } 1 \text { Sylvilagus; } 1 \text { Lepus; } 1 \text { Neotoma; } 1 \\
\text { Geomyidae; } 33 \text { Mammalia, medium; } 7 \text { Artio- } \\
\text { dactyla, medium; } 6 \text { Odocoileus }\end{array}$ & 157 & 93.4 & 13 \\
\hline $9(105-115)$ & $\begin{array}{l}6 \text { Testudines; } 19 \text { Mammalia; } 36 \text { Mammalia, } \\
\text { small; } 4 \text { Sylvilagus; } 3 \text { Sigmodon; } 2 \text { Carniv- } \\
\text { ora; } 19 \text { Mammalia, medium; } 3 \text { Artiodactyla; } \\
5 \text { Artiodactyla, medium; } 1 \text { Odocoileus; } 1 \\
\text { Mammalia, fetal/juvenile }\end{array}$ & 99 & 46.1 & 10 \\
\hline $10(115-125)$ & $\begin{array}{l}1 \text { Osteichthyes; } 5 \text { Testudines; } 1 \text { Serpentes; } 1 \\
\text { Aves; } 33 \text { Mammalia; } 28 \text { Mammalia, small; } 1 \\
\text { Sylvilagus; } 3 \text { Rodentia; } 1 \text { Canidae; } 5 \text { Mam- } \\
\text { malia, medium; } 1 \text { Artiodactyla; } 3 \text { Artiodac- } \\
\text { tyla, medium; } 1 \text { Odocoileus; } 5 \text { Mammalia, } \\
\text { fetal/juvenile }\end{array}$ & 88 & 27.3 & 13 \\
\hline $11(125-135)$ & $\begin{array}{l}3 \text { Testudines; } 1 \text { Aves; } 24 \text { Mammalia; } 14 \\
\text { Mammalia, small; } 2 \text { Sylvilagus; } 1 \text { cf. Syl- } \\
\text { vilagus; } 6 \text { Canidae; } 24 \text { Mammalia, medium; } \\
3 \text { Artiodactyla, medium; } 1 \text { Odocoileus }\end{array}$ & 79 & 40.5 & 9 \\
\hline $12(135-145)$ & $\begin{array}{l}1 \text { Vertebrata; } 6 \text { Testudines; } 1 \text { Aves; } 46 \\
\text { Mammalia; } 17 \text { Mammalia, small; } 2 \text { Cani- } \\
\text { dae; } 16 \text { Mammalia, medium; } 30 \text { Artiodac- } \\
\text { tyla, medium }\end{array}$ & 119 & 85.8 & 9 \\
\hline $13(145-155)$ & $\begin{array}{l}1 \text { Vertebrata; } 1 \text { Serpentes; } 111 \text { Mammalia; } \\
4 \text { Mammalia, small; } 1 \text { Carnivora; } 64 \text { Mam- } \\
\text { malia, medium; } 1 \text { Artiodactyla, medium; } 1 \\
\text { Bison; } 2 \text { cf. Bison }\end{array}$ & 186 & 118.4 & 8 \\
\hline
\end{tabular}


Table 6-1. Faunal Remains by Level and Elevation (recoveries from Units $\mathbf{3}$ and $\mathbf{4}$ are combined)

\begin{tabular}{|c|c|c|c|c|}
\hline $\begin{array}{c}\text { Level } \\
\text { (Elevation, } \\
\text { cmbd) }\end{array}$ & Taxon and Count & $\begin{array}{l}\text { Final Count* } \\
(\mathrm{N}=\text { MNISP) }\end{array}$ & $\begin{array}{c}\text { Final } \\
\text { Mass } \\
\text { (grams) }\end{array}$ & $\begin{array}{l}\text { Rich- } \\
\text { ness*** }\end{array}$ \\
\hline $14(155-165)$ & $\begin{array}{l}2 \text { Vertebrata; } 4 \text { Testudines; } 37 \text { Mammalia; } \\
21 \text { Mammalia, small; } 12 \text { Mammalia, medi- } \\
\text { um; } 1 \text { Artiodactyla, hypsodont; } 18 \text { Artiodac- } \\
\text { tyla, medium; } 1 \text { Odocoileus; } 11 \text { Mammalia, } \\
\text { medium to large; } 45 \text { Bison; } 1 \text { Mammalia, } \\
\text { fetal/juvenile }\end{array}$ & 153 & 160.6 & 9 \\
\hline $15(165-175)$ & $\begin{array}{l}3 \text { Testudines; } 3 \text { Aves; } 64 \text { Mammalia; } 28 \\
\text { Mammalia, small; } 3 \text { Sylvilagus; } 1 \text { Canidae; } \\
1 \text { Artiodactyla cf. Antilocapra; } 1 \text { Antilo- } \\
\text { capra americana; } 2 \text { Artiodactyla, medium; } 1 \\
\text { Odocoileus; } 8 \text { Mammalia, medium }\end{array}$ & 115 & 41.4 & 10 \\
\hline $16(175-185)$ & $\begin{array}{l}1 \text { Osteichthyes; } 7 \text { Testudines; } 25 \text { Mammalia; } \\
22 \text { Mammalia, small; } 2 \text { Sylvilagus; } 5 \text { Mam- } \\
\text { malia, medium; } 2 \text { Artiodactyla, medium }\end{array}$ & 64 & 45.6 & 7 \\
\hline $17(185-195)$ & $\begin{array}{l}1 \text { Osteichthyes; } 1 \text { Testudines; } 19 \text { Mam- } \\
\text { malia; } 2 \text { Mammalia, small; } 1 \text { Neotoma; } 8 \\
\text { Artiodactyla, medium }\end{array}$ & 32 & 19 & 6 \\
\hline $18(195-205)$ & $\begin{array}{l}6 \text { Mammalia; } 8 \text { Mammalia, small; } 1 \text { Lepus; } \\
1 \text { Mammalia, medium; } 6 \text { Artiodactyla, } \\
\text { medium }\end{array}$ & 22 & 21.2 & 5 \\
\hline $19(205-215)$ & 1 Mammalia; 2 Mammalia, small & 3 & 0.9 & 2 \\
\hline $20(215-225)$ & 1 Mammalia, medium & 1 & 3.4 & 1 \\
\hline $21(225-235)$ & No bone recovered & 0 & 0 & 0 \\
\hline $22(235-245)$ & 2 Mammalia & 2 & 2.1 & 1 \\
\hline $23(245-255)$ & 5 Mammalia & 5 & 1.4 & 1 \\
\hline $24(255-265)$ & No bone recovered & 0 & 0 & 0 \\
\hline $25(265-275)$ & 1 Mammalia & 1 & 0.2 & 1 \\
\hline $26(275-285)$ & 3 Mammalia, small & 3 & 1.1 & 1 \\
\hline 27 (285-295) & 1 Mammalia & 1 & 0.5 & 1 \\
\hline
\end{tabular}

\section{Trends in Faunal Data}

Trends in recovery are charted by both count and mass (Figure 6-1). In addition to these metrics, a measure called assemblage richness provides an indication of the number of different taxa that are present. Richness is simply the number of identifiable species that are present, and changes over time as an indication of environmental variation as well as prey choice behavior (see Kintigh 1984, 1989). With such a small sample, this metric does not show 


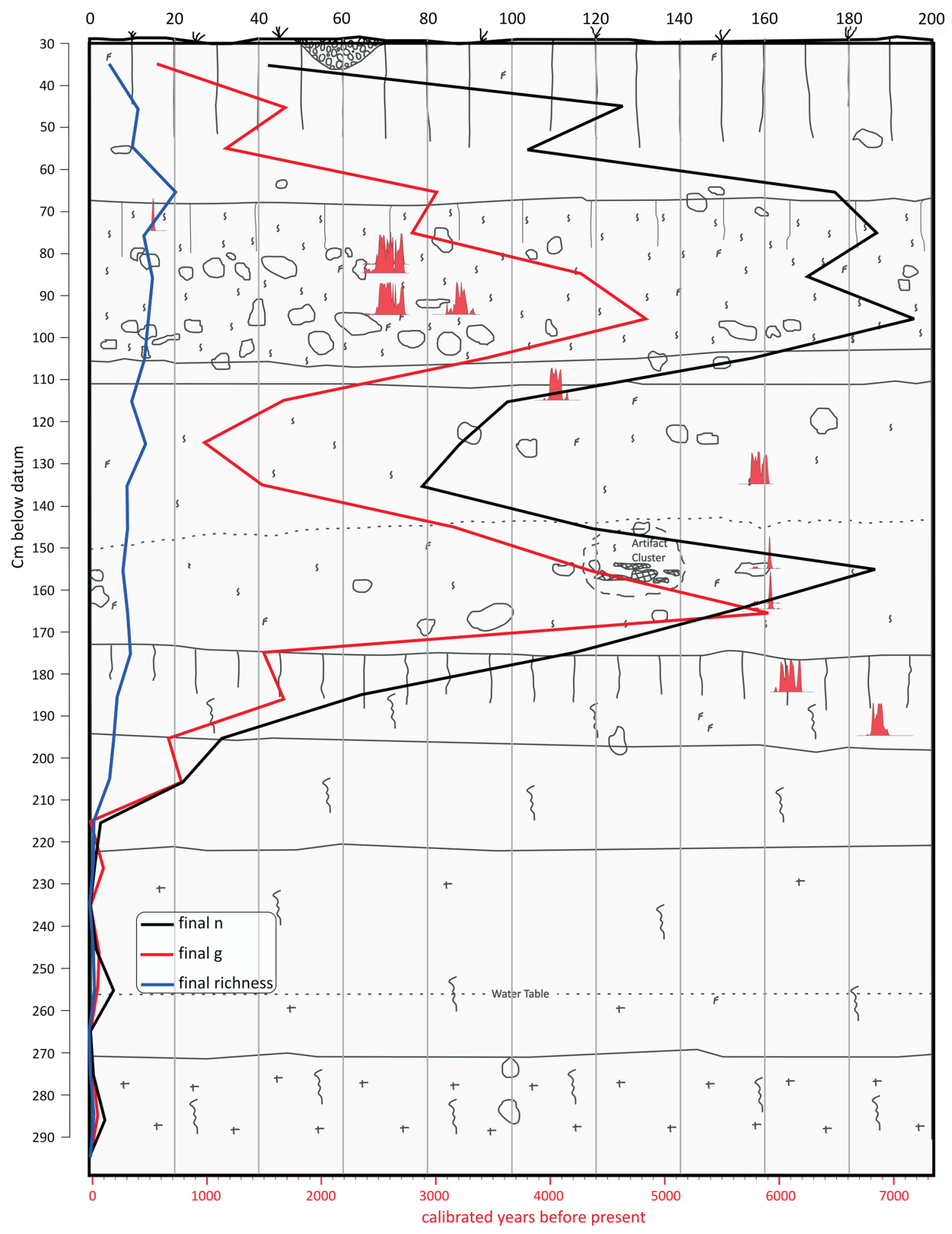

Figure 6-1. Faunal assemblage from Units 3 and 4 by MNISP, mass (g), and richness. Bison are present in both peaks (as defined by frequency and mass). 
marked variation and should not be over-interpreted. Still, changes are evident that may indicate important shifts in the zooarchaeological assemblage over time. Considering this project's analytical focus on local chronology as influenced by the availability of certain key species, particularly bison, special note is made of the presence of identifiable bison remains. Here, only individual specimens that could confidently be identified as bison are included; no remains are listed as "probable bison" or "bison-size." Based on these data, some trends in the occurrence and co-occurrence of taxa can be discussed.

Bone count and mass have a bimodal peak in occurrence from the surface down through the deepest level. The first peak occurs in level 7 (95-105 cmbd) for both count and mass. Values peak again in level 13(155-165 cmbd), with a minimum in level 11 (135-145 cmbd). Count exhibits a steady decline below $165 \mathrm{cmbd}$ (levels 13 to 19), where slope levels off below 5 . Mass peaks again in level $14(165-175 \mathrm{cmbd})$, with a minimum occurring in level 10 (125-135 cmbd). Mass drops sharply between 14 and 15, peaks very slightly in level 16 (185-195 cmbd), and decreases stepwise until level $19(215-225 \mathrm{cmbd})$, where mass levels out below $3.5 \mathrm{~g}$. The peaks in count and mass cannot be attributed specifically to the presence of bison in these levels, since total count includes small as well as large bodied game. Rather, the bimodal pattern seems to indicate that, during certain cultural periods, the overall return of animal elements to this site increased. Secondarily, bison were present during both peaks, and it perhaps the case that the presence of bison without additional species is a defining characteristic of the earlier peak. The later period of increased animal exploitation includes not only the Late Archaic period of bison hunting, but also deposits from later Archaic and even Late Prehistoric Toyah periods that are either intermixed or are so tightly compressed that they are essentially indistinguishable. It is interesting that between these periods, corresponding with what is essentially the Middle Archaic time period, animal frequency drops off dramatically by both count and weight.

Taphonomically, bone condition is fairly consistent through the section. Bone fragments in some levels (levels 2, 3, 5, 6, 8-15, 17) exhibit a range of weathering. Burned bone was recovered from all but levels 21 and 23 (no bone recovery), and 25-27. Bone from levels 16 through 23 exhibit encrustation of $\mathrm{CaCO}_{3}$. Even though bone preservation does not appear to decline with depth, bone counts and mass decline along with taxonomic richness. The presence of $\mathrm{CaCO}_{3}$ concretions and encrustation indicates a fluctuating water table, which may explain the dearth of skeletal material in the lower levels.

\section{Observations about Recovery Patterns by Animal Size and Type}

Some preliminary observations are possible regarding the presence and co-occurrence of different species.

\section{Reptiles, Amphibians, and Birds and their Occurrence}

Fish occur in levels $2-5,8-10,16$, and 17 . The specimens include vertebrae and craniodental material. Only one specimen, from level 3 , is burned. It may be important that bison are absent 
from all levels in which fish are present with the exception of levels 2-5. Anura (frogs and toads) were identified from levels $3,4,6-8$ based on ilia and distinctive limb elements. None was burned.

Turtle shell fragments occur throughout the column, recognizable from levels 2-17, except for level 14. This material mainly comprises small pond or mud turtles, with one soft-shelled turtle identified in level 5. Nearly every level with turtle shell has burned turtle shell, indicating that this was likely an important part of local diets. The presence of turtle throughout the column is not unexpected considering the proximity of the unit to the freshwater springs.

Snake vertebrae were identified from levels 1-7, exclusive of 5, and also in levels 10 and 13. The only burned vertebra occurs in level 1 . Bird occurs sporadically through the column between levels 2 (tentatively identified) and 15. Avian material derives from small-bodied forms and are probably passerines.

\section{Small Mammals and their Occurrence}

Leporids (hares and rabbits) occur consistently between levels 4-18 with the exception of levels 7, 12, 13, and 17. Lepus (hare) occurs in levels 5, 6, 8, 14, and 18, coincident and adjacent to levels in which Antilocapra occur (except level 18). The same pattern applies, albeit in a less clearly-defined manner, to co-occurrence with Bison. These three taxa (hare, antelope, bison) are sympatric over open grasslands, and this pattern indicates that diverse choices of prey were available during periods when presumably top-ranked species (bison) were present.

Sylvilagus (cottontail rabbit) was recovered from levels 4, 5, 8-11, 15, and 16. Level 9 yielded a minimum number of three Sylvilagus sp, represented by right dentaries, along with a right calcaneum fragment. Sylvilagus is abundantly represented between levels 8-11, an abundance which coincides with a decline in specimen count and mass values for the assemblage.

Rodents, including Rodentia, Sigmodon (cotton rat), Neotoma (wood rat) and Geomyidae (pocket gophers), collectively occur only in upper levels (2-10, exclusive of level 3) with an outlier Neotoma identified in level 17. Most are small (Geomyidae, Sigmodon, Neotoma) but one in Unit 3 level 10 is much larger; this specimen may be a porcupine.

\section{Medium Mammals and their Occurrence}

Carnivora material is recognized between levels 4 and 15, inclusive. Consisting largely of dental material, some of this is identifiable to Canidae and is probably coyote (Canis latrans). A claw from level 4 may be assignable to Felidae. A specimen that appears similar to a metapodial of $H$. sapiens or big Canis sp. was recovered in level 10.

Medium artiodactyl remains are identified from levels 2-18, but only identified to genus in levels 2-4, 6-11, and 15. Positively identified American antelope (Antilocapra) is confined to 
levels 6, 7, and 15, where it always co-occurs with white tailed deer (Odocoileus). Odocoileus is positively identified largely throughout the upper section (levels 3-11, excluding level 5) and overlaps with both Antilocapra and modern bison (Bison bison), as well as other common subsistence taxa. Bone assignable only to Artiodactyla, medium, is also present through the section and is more commonly unaccompanied by either Antilocapra or Odocoileus between levels 12 and 18. This may be due in part to poorer preservation in lower levels. Presumably, white tailed deer would have been available during virtually periods that are represented in this sequence, and apparent absence of this taxon likely indicates preservation or recovery biases.

Fetal or juvenile bone are present in levels 4-6, 9, and 10. These appear similar to but are not entirely coincident with Bison material. Based on the fact that no identified bison is in levels $8-11$, it is probable that most or all of this material may be assignable to deer or pronghorn.

\section{Bison and its Occurrence}

Bison has been identified in levels 3-7, 13, and 14. These levels correspond with bimodal peaks in count and mass (see Figure 6-1). The upper peak represents at least two archaeological subperiods within the Late Archaic of bison exploitation, and stratigraphic resolution here is not sufficient for clearly distinguishing between these. Based on the radiocarbon dates on bison from levels 6 and 7, the sequence here is in proper order. Yet the lower assays are approximately 500 years older than the upper assays, and these two strata are essentially contiguous in the profile. The lower bison zone, however, clearly defines the Calf Creek component in this deposit.

None of the Bison material appears to have been burned, but one femur or humerus fragment from level 14 had been cut. One tooth fragment from level 2 has red staining from an unknown pigment, possibly red ochre.

\section{Unidentifiable Bone and its Occurrence}

Mammalian bone identifiable only to size range occurs through the section consistently down through level 19. Bone recovery from levels $20-27$ is altogether sparse. The bone does not appear to be more degraded but bone counts drop by 86 percent from level 18 ( $n=22)$ to level $19(\mathrm{n}=3)$, and does not increase in deeper levels. Considering the overall decrease in artifact recovery as well, the lower part of this deposit appears to have been a period of relatively rapid aggradation and accumulation. Additionally, at least for the faunal material, consistently moist sediments have undoubtedly resulted in some loss of material.

\section{Discussions of the Faunal Data}

Carcass portion distribution patterns are not likely to emerge from this small excavation block. Within levels the remains of such game as medium Artiodactyla (collectively) and Bison tend 
to be representative across a carcass, i.e., a combination of teeth, axial elements, and fore and hind limb elements. Because the overall exposure is so limited, however, any comments regarding the patterned distribution of carcass portion seems unwarranted.

Taxonomic richness, the number of taxa identified in the assemblage, peaks in level 4 at 20 taxa, and steadily decreases down profile with smaller peaks at levels 10 and 15. Altogether, variation in richness seems relatively minor, and should be interpreted with caution. Still, richness values are consistently higher, by as much as 60 percent, above level 11 (135-145 cmbd) than they are in the Calf Creek zone and below. Based on radiocarbon ages, this depth marks the beginning of what archaeologists can confidently refer to as the Middle Archaic. Some of this variation may be the result of recovery or preservation bias, but it is also likely that there were meaningful and sustained differences in terms of additional prey species that appear in local subsistence behaviors by the beginning of the Middle Archaic, immediately following Calf Creek times. One possible interpretation of the richness data is that, during the Calf Creek horizon (at least), the exploitation of bison and other artiodactyls, including white tail deer and perhaps antelope, may have displaced certain other lower-ranked prey from the diet. Following Calf Creek, which essentially concludes the Early Archaic, the number of prey species that were targeted increased notably, representing a dietary shift toward more broadspectrum subsistence behavior. When bison reappeared on the landscape in the Late Archaic, they were once again integrated into local diets. However, the animal portions of diets from this time onward continue to reflect the same kinds of breadth and diversity that had been practiced since the end of the Calf Creek period.

Considering the rapid decline in faunal recovery that starts at approximately level 15 (175-185 cmbd), very little can be said about animal resource availability or abundance immediately prior to Calf Creek times. The presence of antelope in level 15 suggests that the transition to a grasslands-like habitat surrounding Spring Lake was relatively gradual. Otherwise, the exploitation of fish and medium-size artiodactyls before Calf Creek suggests a diet reliant on locally-available broad-spectrum resources. 



\section{Chapter 7 Artifacts}

by Amy E. Reid and David M. Yelacic

Artifacts recovered from this excavation include chipped stone lithics, fire-cracked rock, modified bone, a shell bead, and aboriginal pottery. Lithic artifacts include projectile points and point fragments, many of which are stylistically diagnostic to a particular time period; bifaces from tool production and use; unifaces and other edge modified expedient tools; flake cores; and debitage, or the flaking debris from tool production. Bifaces, unifaces, edge modified tools, and cores are briefly described and representative specimens are illustrated. Detailed measurements and additional data are presented in appendices at the end of this report. Debitage and fire-cracked rock presented in terms of abundance by count and weight. Information about the frequency of recovery for both categories helps characterize the overall deposit and site formation processes at this locale, and detailed analyses in the future would potentially bring additional understanding to these and other questions. The marine shell bead is discussed in detail, and descriptions are provided for the ceramic fragments. The category of ceramics is best considered in the context of larger, regional patterns of ceramic manufacture and use during the Terminal Late Prehistoric or Protohistoric to Early Historic period. Such analyses, however, are still underway or have not yet been undertaken, and these data are presented here with the idea that they will be useful for future studies.

\section{LiTHICS}

This section describes the culturally altered lithic material (chipped stone) recovered from all controlled excavations. Most of the collection $(n=14,985)$ consists of unmodified lithic debitage $(n=$ 14,875). The remaining material was organized into the following categories: projectile points, bifaces, unifaces, flake tools, and cores. All projectile points recovered from hand excavation and monitoring activities were included in the present analysis, while analysis of the other categories concentrated only on material recovered from excavation Units 3 and 4. 


\section{Projectile Points}

A total of 59 projectile points and point fragments were recovered. Of these, 54 are dart points and five are arrow points. Forty three projectile points were assigned a type based on the commonly accepted point typology developed for Central and South Texas. Twenty different types were identified including: Martindale, Merrell, Uvalde, Gower, and Bell (Calf Creek) for the Early Archaic ( $=12$ ); Nolan, Travis, Baird and Almagre/Langtry for the Middle Archaic ( $\mathrm{n}=9)$; Bulverde, Pedernales and Lange for the Late Archaic I ( $\mathrm{n}=10)$; Castroville ( $\mathrm{n}$ = 2) for the Late Archaic II; Ensor, Ellis, Edgewood, Fairland for the Late Archaic III (n = 5); Darl and Scallorn for the Transitional Archaic/Austin period $(\mathrm{n}=2)$; and Perdiz for the Late Prehistoric $(n=3)$. In addition, one untypable arrow point and fifteen untypable dart points were recovered. Many of these points could not be confidently assigned to an established type because they either do not have enough diagnostic attributes or because of their fragmentary or incomplete condition. Generally, projectile points were recovered in approximate age order by depth, with younger points occurring toward the top of the deposit and older point styles generally occurring in deeper levels toward the bottom. In some cases, however, older styles are found higher up in the deposit. These instances do not necessarily indicate mixed sediments; the cultural reuse of older points is commonly observed in prehistoric sites and can account for the apparently "upward" movement of older points into younger deposits. Overall, patterns of point recovery indicate that this part of the Spring Lake site contains relatively unmixed deposits (Table 7-1). This pattern of recovery confirms earlier observations to this effect based on radiocarbon data.

Table 7-1. Projectile Points by Elevation (recoveries from Units 3 and 4 are combined)

\begin{tabular}{|c|c|c|c|c|c|c|c|c|}
\hline & & & $\mathbf{T} \quad \mathrm{i}$ & $\mathbf{e}$ & $\mathbf{P}$ & $\mathbf{i}$ & d & \\
\hline $\begin{array}{c}\text { Level } \\
\text { (Elevation, } \\
\text { cmbd) }\end{array}$ & Point Types & 㿣 & 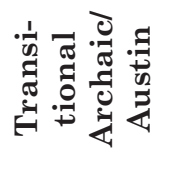 & 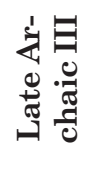 & 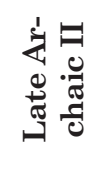 & 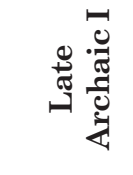 & 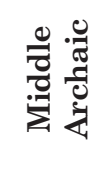 & 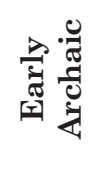 \\
\hline $1(0-35)$ & - & - & - & - & - & - & - & - \\
\hline $2(35-45)$ & $\begin{array}{l}1 \text { Perdiz } \\
1 \text { Darl }\end{array}$ & 1 & 1 & - & - & - & - & - \\
\hline $3(45-55)$ & & - & - & - & - & - & - & - \\
\hline $4(55-65)$ & 1 Pedernales & - & - & - & - & 1 & & \\
\hline $5(65-75)$ & $\begin{array}{l}1 \text { Ellis } \\
2 \text { Edgewood }\end{array}$ & - & - & 3 & - & - & - & - \\
\hline $6(75-85)$ & $\begin{array}{l}1 \text { Lange } \\
1 \text { Travis } \\
1 \text { Baird } \\
1 \text { Martindale }\end{array}$ & - & - & - & - & 1 & 2 & 1 \\
\hline $7(85-95)$ & 2 Pedernales & - & - & - & - & 2 & - & - \\
\hline
\end{tabular}


Table 7-1. Projectile Points by Elevation (recoveries from Units 3 and 4 are combined)

\begin{tabular}{|c|c|c|c|c|c|c|c|c|}
\hline & & & $\mathbf{T} \mathbf{i}$ & e & $\mathbf{P}$ & i & d & \\
\hline $\begin{array}{c}\text { Level } \\
\text { (Elevation, } \\
\text { cmbd) }\end{array}$ & Point Types & हี & 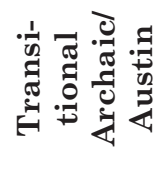 & 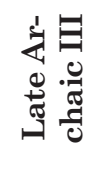 & 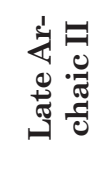 & 总 & 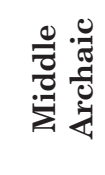 & 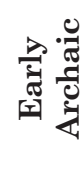 \\
\hline $8(95-105)$ & & - & - & - & - & - & - & - \\
\hline $9(105-115)$ & & - & - & - & - & - & - & - \\
\hline $10(115-125)$ & $\begin{array}{l}1 \text { Nolan } \\
1 \text { Almagre/ } \\
\text { Langtry }\end{array}$ & - & - & - & - & - & 2 & - \\
\hline $11(125-135)$ & 1 Nolan & - & - & - & - & - & 1 & - \\
\hline $12(135-145)$ & 1 Merrell & - & - & - & - & - & - & 1 \\
\hline $13(145-155)$ & $\begin{array}{l}1 \text { Martindale } \\
1 \text { Bell (Calf } \\
\text { Creek) }\end{array}$ & - & - & - & - & - & - & 2 \\
\hline $14(155-165)$ & 1 Merrell & - & - & - & - & - & - & 1 \\
\hline $15(165-175)$ & & - & - & - & - & - & - & - \\
\hline $16(175-185)$ & $\begin{array}{l}1 \text { Merrell } \\
2 \text { Uvalde } \\
1 \text { Bell (Calf } \\
\text { Creek) }\end{array}$ & - & - & - & - & - & - & 4 \\
\hline $17(185-195)$ & & - & - & - & - & - & - & - \\
\hline $18(195-205)$ & & - & - & - & - & - & - & - \\
\hline $19(205-215)$ & & - & - & - & - & - & - & - \\
\hline $20(215-225)$ & & - & - & - & - & - & - & - \\
\hline $21(225-235)$ & & - & - & - & - & - & - & - \\
\hline $22(235-245)$ & & - & - & - & - & - & - & - \\
\hline $23(245-255)$ & & - & - & - & - & - & - & - \\
\hline $24(255-265)$ & & - & - & - & - & - & - & - \\
\hline $25(265-275)$ & & - & - & - & - & - & - & - \\
\hline $26(275-285)$ & & - & - & - & - & - & - & - \\
\hline $27(285-295)$ & & - & - & - & - & - & - & - \\
\hline $28(295-300)$ & 1 Gower & - & - & - & - & - & - & 1 \\
\hline
\end{tabular}

All typable points were classified by Elton Prewitt; these were measured for thickness to the nearest $0.1 \mathrm{~mm}$ and weighed to the nearest $0.1 \mathrm{~g}$. Dimensions of complete specimens (maximum length and width, stem length, neck width, basal width and depth) were recorded to the nearest $0.1 \mathrm{~mm}$. Metric and observed data for each point are provided in Appendix A. 
Following the format used by LeDoux and Lohse (2011), summaries of point types recovered by time period are presented below, beginning with the Early Archaic. Each point type summary includes its phase in Central Texas chronology (Prewitt 1981) and its series designation, if available (Jelks 1978; Prewitt 1995). The summaries also provide the total number of points recovered, specimen numbers and descriptions of their condition, retouch, use-wear and key technological aspects, including flaking patterns and edge modification. When describing the condition of the specimens, macroscopic damage was assessed by using four descriptors for break patterns: snap, crushing, burination, and thermal fracture. Specimen numbers are used in reference to specific artifact descriptions.

\section{Early Archaic}

\section{Martindale}

Phase: Late San Geronimo

Series: NS

$\mathrm{n}=2$ (Specimen Nos. 312-3 and 405-2)

Condition and Breakage: One specimen is a base fragment (312-3) and the other exhibits a snap fracture, missing distal tip, and damage to one barb and one basal corner on the same side (405-2). Specimen 312-3 is finely worked and exhibits almost perfect symmetry (Figure 7-1 A, B).

Retouch: Specimen 405-2 has retouch on its lateral edges.

\section{Merrell}

Phase: N/A

Series: NS

$\mathrm{n}=3$ (Specimen Nos. 313-03, 315-1, 411-05)

Condition and Breakage: Specimen 315-1 is a proximal fragment with a snap fracture leaving only the base and stem. Specimen 313-03 is missing one basal ear and one shoulder had been damaged. Specimen $411-5$ is also a proximal fragment with a snap fracture. It exhibits damage to both shoulders and one basal ear. All three have random flake patterning (Figure 7-1 C-E).

Retouch: There is evidence of retouch on the blade and shoulders of specimen 313-3.

\section{Uvalde}

Phase: Late San Geronimo

Series: NS

$\mathrm{n}=2($ Specimen Nos.415-1, 415-6)

Condition and Breakage: Specimen 415-1 is a nearly complete projectile point with a beveled blade. A small portion of the distal tip has snapped off, and the lateral edges are slightly serrated from retouch. On one face, there is a flake scar that extends horizontally all the way across, with no midline. All other flake scars are random. 

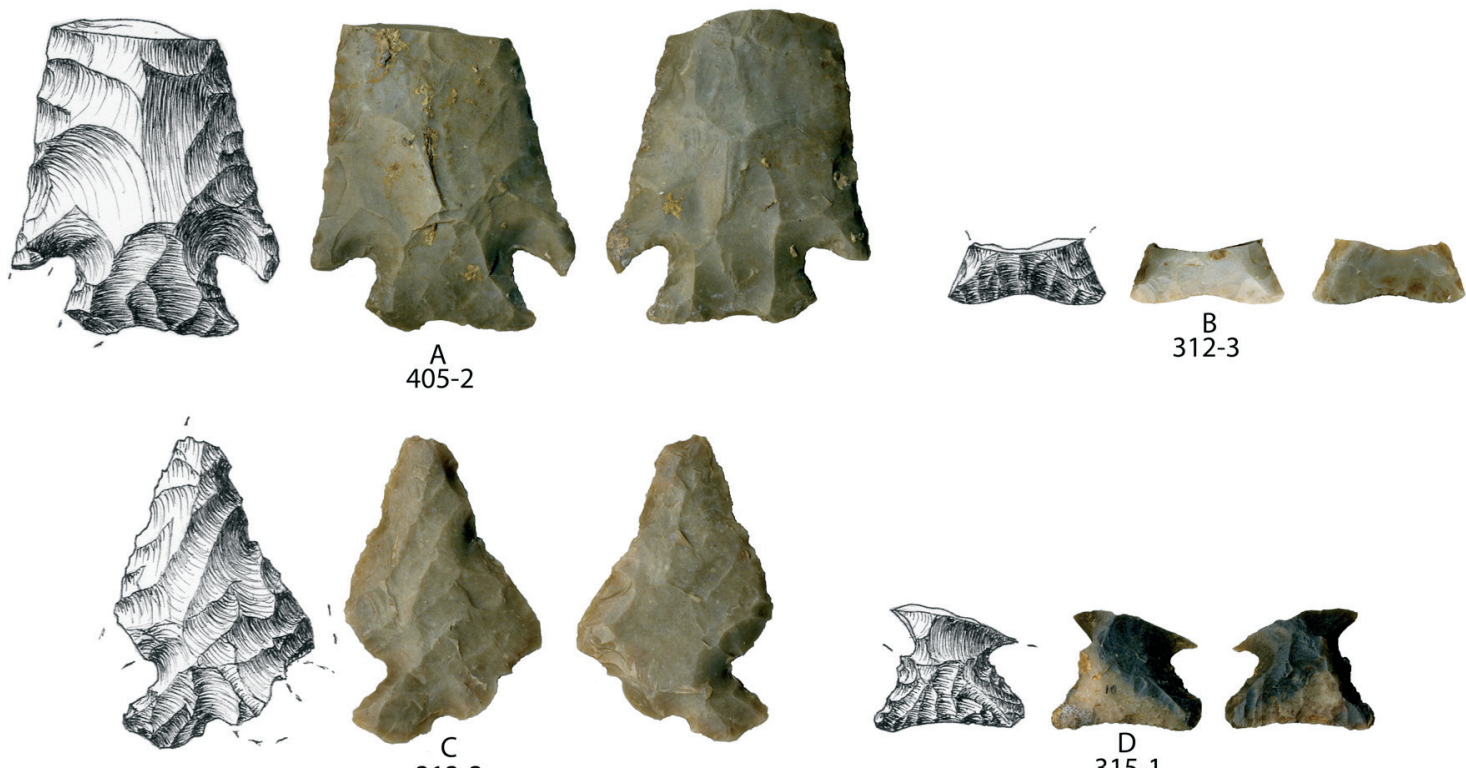

313-3
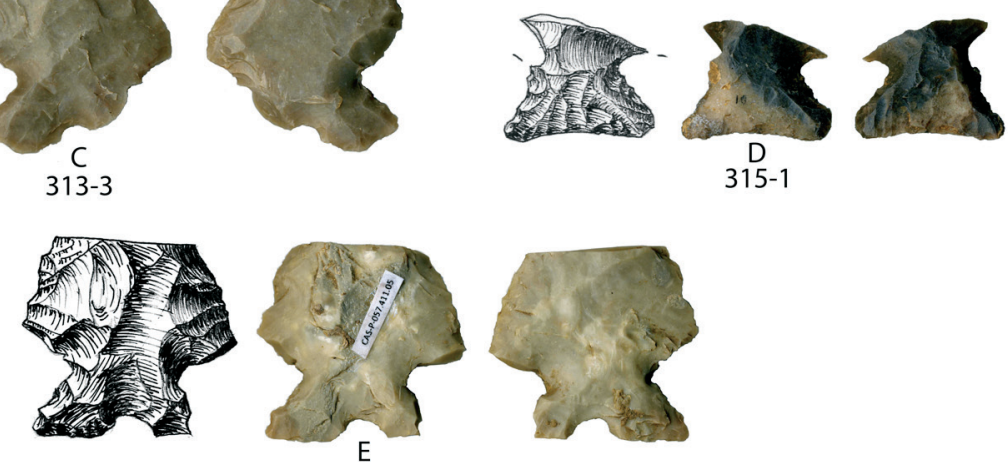

411-5

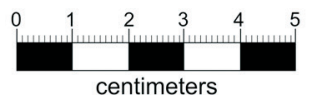

Figure 7-1. Early Archaic projectile points: (A-B) Martindale; (C-E) Merrell.

Specimen 415-6 is complete and exhibits one beveled edge. The base has been thinned and smoothed and the flake patterning is random with step terminations on both faces (Figure 7-2 A, B).

Retouch: The lateral edges of both specimens have been retouched creating step terminations.

\section{Gower}

Phase: Early San Geronimo

Series: Lampasas

$\mathrm{n}=2($ Specimen Nos. 53-14, 427-1)

Condition and Breakage: Specimen 53-14 is missing the distal tip from impact, one barb and one basal ear. Specimen 427-1 is a Gower projectile point that has been reworked into a drill or awl. It is missing its distal tip due to a snap fracture and exhibits random 


\section{Chapter 7}
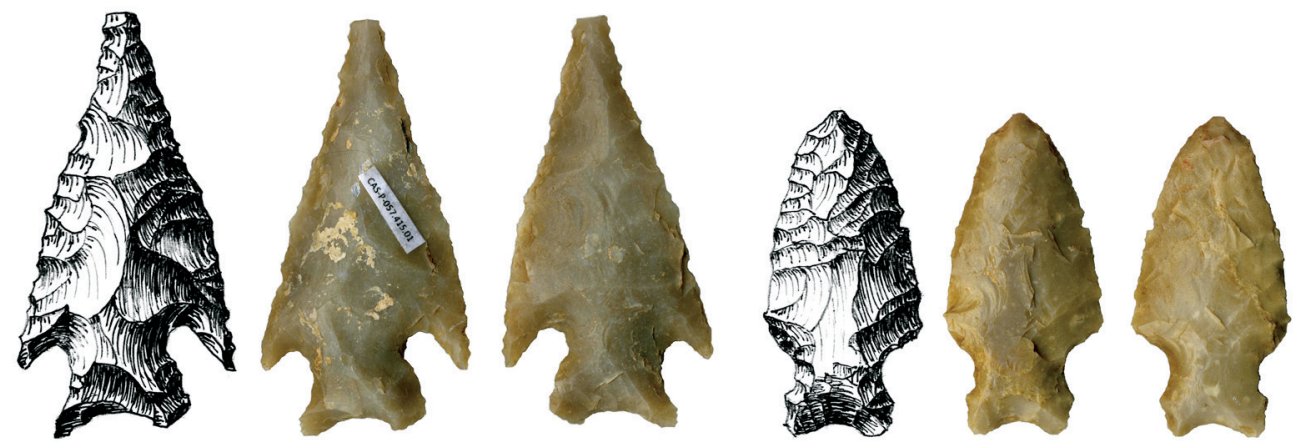

A

B

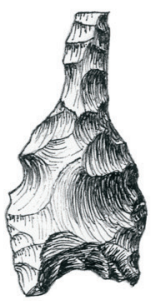

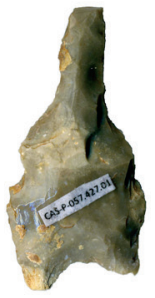

C

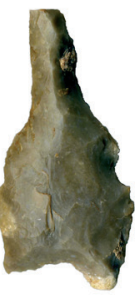

$427-1$
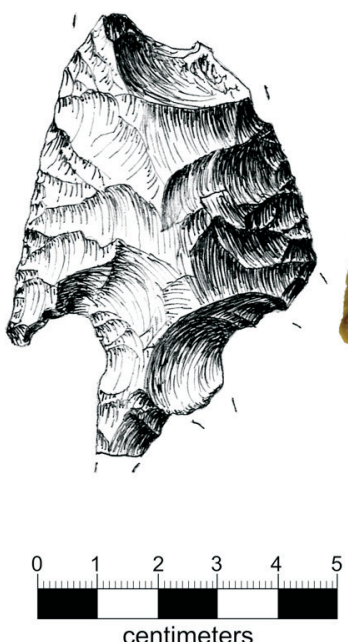

centimeters

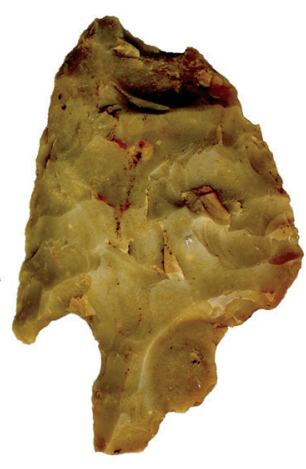

D3-14

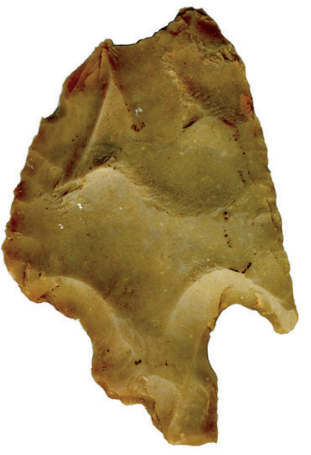

Figure 7-2. Early Archaic projectile points: (A-B) Uvalde; (C-D) Gower.

flake patterning with step terminations on both faces. The specimen is also missing its barbs; it is difficult to determine if they broke off during use before it was reworked, or if they were purposely removed during the reworking (Figure 7-2 C, D).

Retouch: Both specimens exhibit retouch. The blade of 427-1 has been reworked into a drill or perforator tool and the lateral edges of the stem have been slightly notched, perhaps for hafting.

\section{Bell}

Phase: Late San Geronimo

Series: Stillhouse

$\mathrm{n}=3$ (Specimen Nos. 312-1, 415-7, 430-1)

Condition and Breakage: Specimen 312-1 is missing the distal tip and one barb, both with snap impact fractures. Specimen $430-1$ is a proximal fragment with a transverse fracture. The base consists of coarser grain chert and becomes finer grain toward the body of the point. The edges of this specimen are not well finished, and it is possible that 

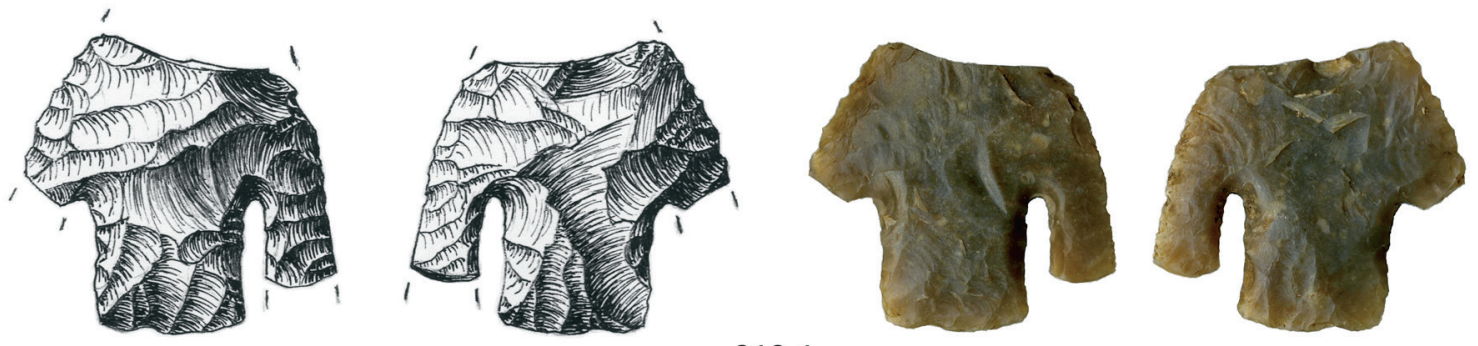

$312-1$
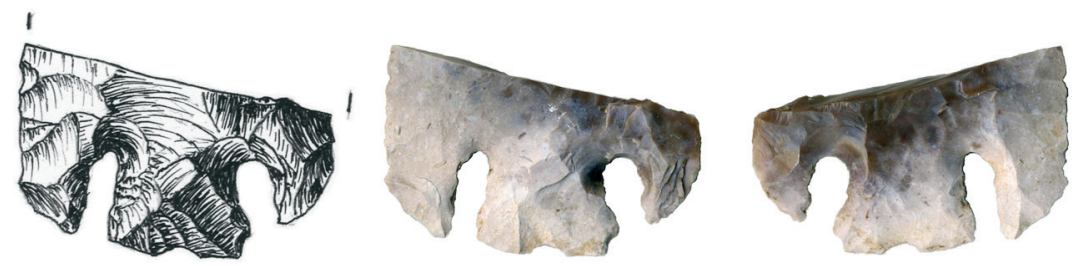

$430-1$
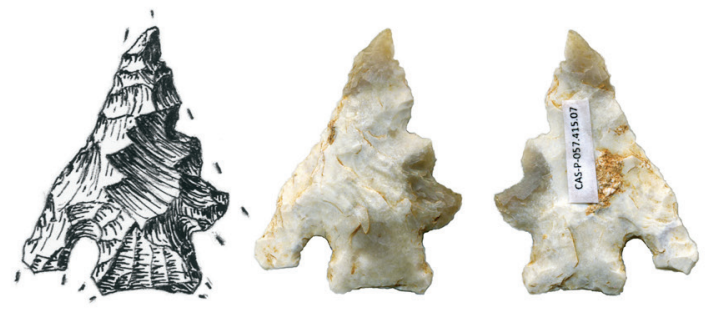

415-7

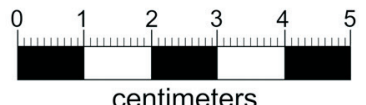

centimeters

Figure 7-3. Early Archaic, Bell (Calf Creek horizon) projectile points.

this point was broken during manufacture. Specimen 415-7 is missing one barb and has a small snap fracture on the other. This specimen is heavily reworked (Figure 7-3).

Retouch: Specimen 312-1 exhibits alternate retouch. 415-7 has been deeply serrated on one edge with two notches.

\section{Middle Archaic}

\section{Almagre/Langtry}

Phase: N/A

Series: Pecos

$\mathrm{n}=1$ (Specimen No. 409-4)

Condition and Breakage: This point is a proximal fragment with a bending transverse fracture. One lateral edge exhibits a series of step fractures, possibly from attempting to thin the edge. The chert material is banded with red in some areas (Figure 7-4 A).

Retouch: Light retouch is evident on edges. 


\section{Chapter 7}

\section{Baird}

Phase: Oakalla

Series: Falcon

$\mathrm{n}=1$ (Specimen No. 305-3)

Condition and Breakage: This specimen is complete and exhibits steep alternate beveling (Figure 7-4 B)

Retouch: Retouch is present on both beveled edges.

\section{Nolan}

Phase: Clear Fork

Series: Parida

$\mathrm{n}=4$ (Specimen Nos. 309-3, 53-2, 56-3, 410-1)

Condition and Breakage: All four specimens have beveled stems. Specimen 56-3 is a complete projectile point with step terminations and random flake patterning. One
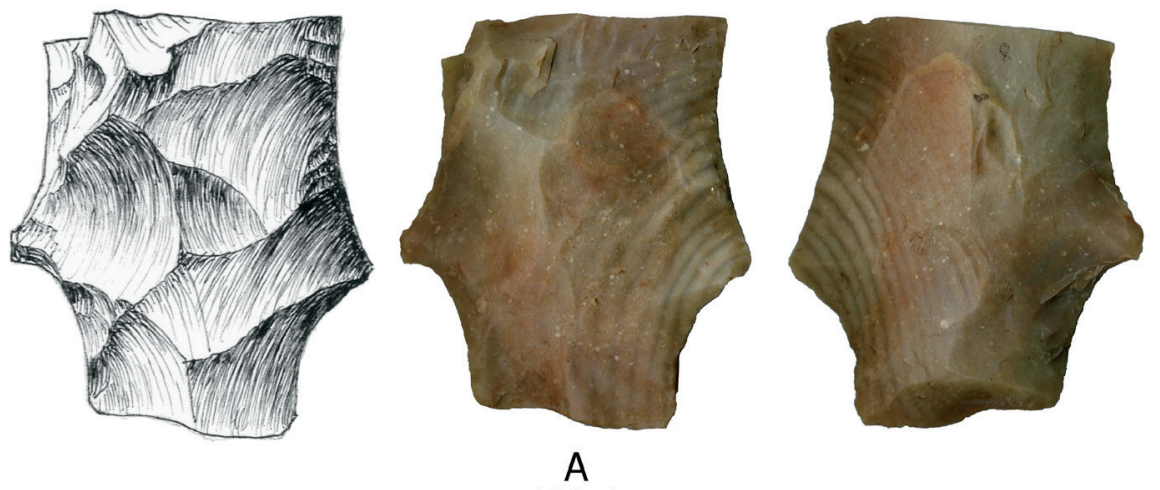

409-4
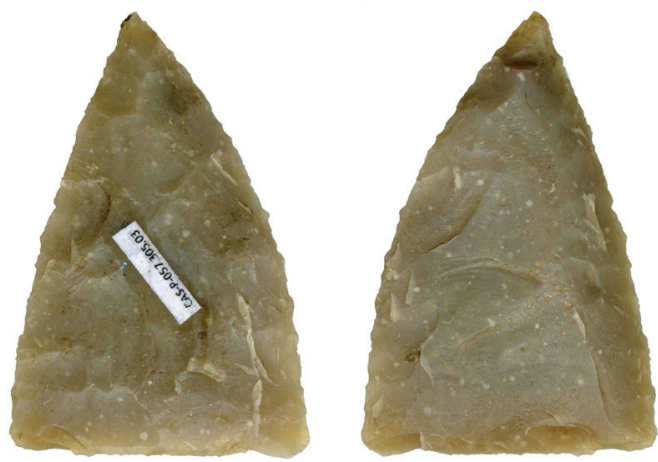

$\mathrm{B}$

305-3

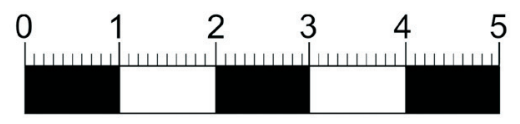

centimeters

Figure 7-4. Middle Archaic projectile points: (A) Almagre/Langtry and (B) Baird. 
lateral edge of the blade is more convex than the other. 309-3 has a burinated impact fracture running diagonally from the distal tip to one shoulder. Specimen 410-1 is a medial fragment with enough of the stem remaining to type as a Nolan. It exhibits random flake patterning with step terminations on both faces. Specimen 53-2, a proximal fragment, exhibits significant heat damage (Figure 7-5).

Retouch: All four specimens have been retouched.

\section{Travis}

Phase: Clear Fork

Series: Pecos

$\mathrm{n}=3$ (Specimen Nos. 305-2, 432-2, 438-1)

Condition and Breakage: Specimens 305-2 and 432-2 are mostly complete with small snap fractures on their distal tips, perhaps from impact. Specimen $438-1$ is a proximal fragment with snap and burin fractures as well as heat damage (Figure 7-6).

Retouch: Retouch is visible on all three specimens.
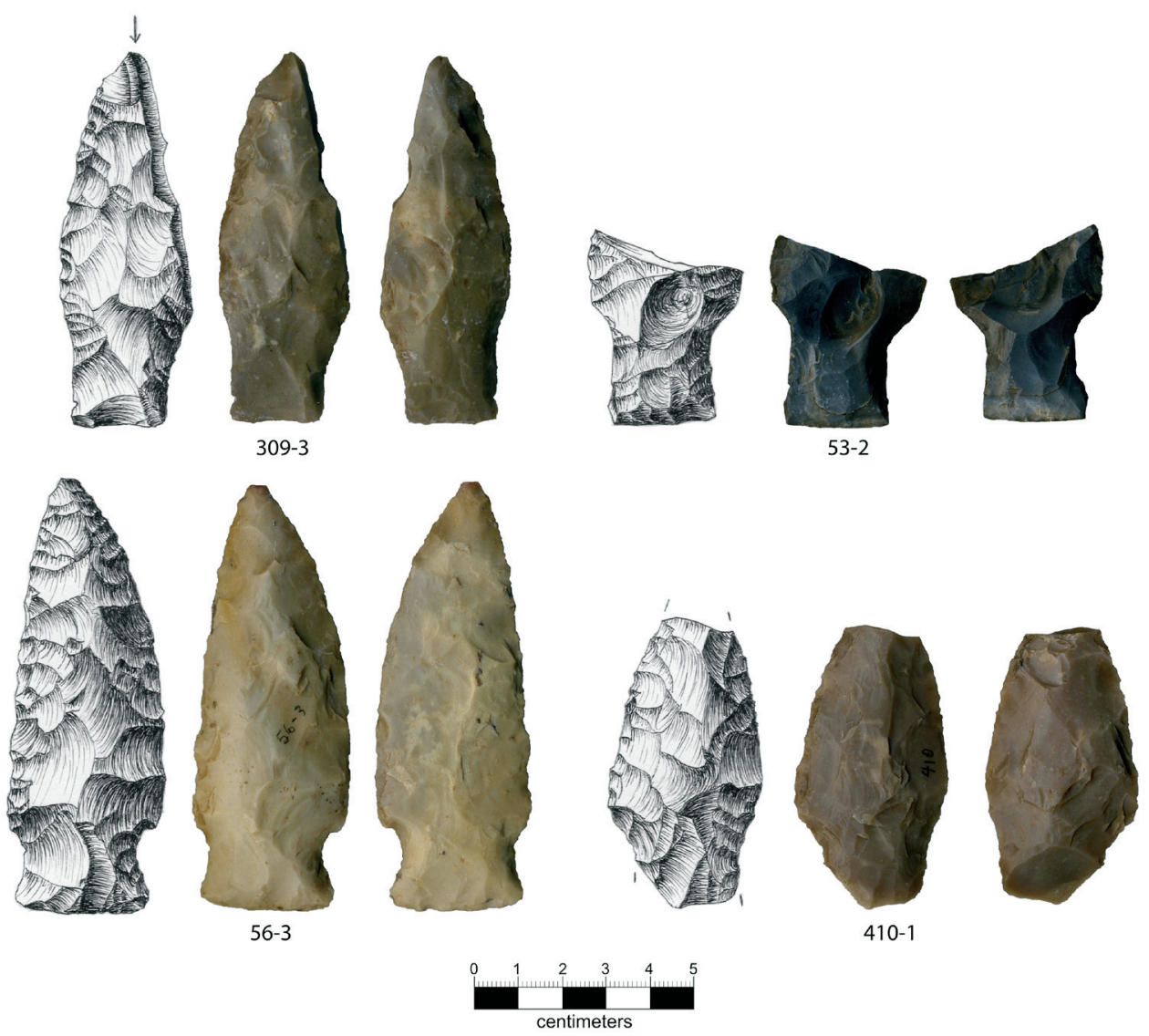

Figure 7-5. Middle Archaic Nolan projectile points. 


\section{Chapter 7}

\section{Late Archaic I}

\section{Bulverde}

Phase: Marshall Ford

Series: Pecos

$\mathrm{n}=1($ Specimen No. 57-1)

Condition and Breakage: This specimen is has minimal impact damage on one barb and to one basal corner. It exhibits random flake patterning and basal smoothing (Figure 7-7 A).

Retouch: Lateral and stem edges have been retouched.

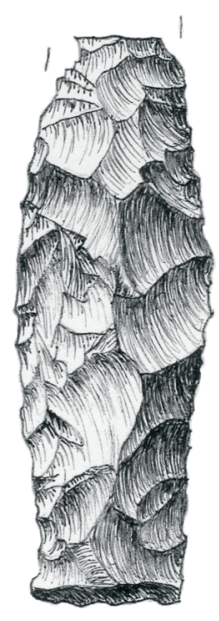

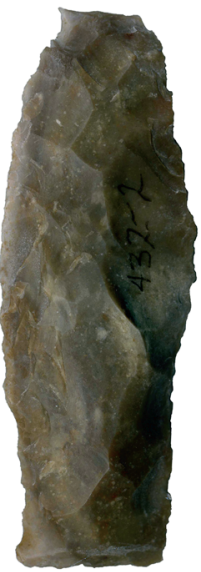

$432-2$
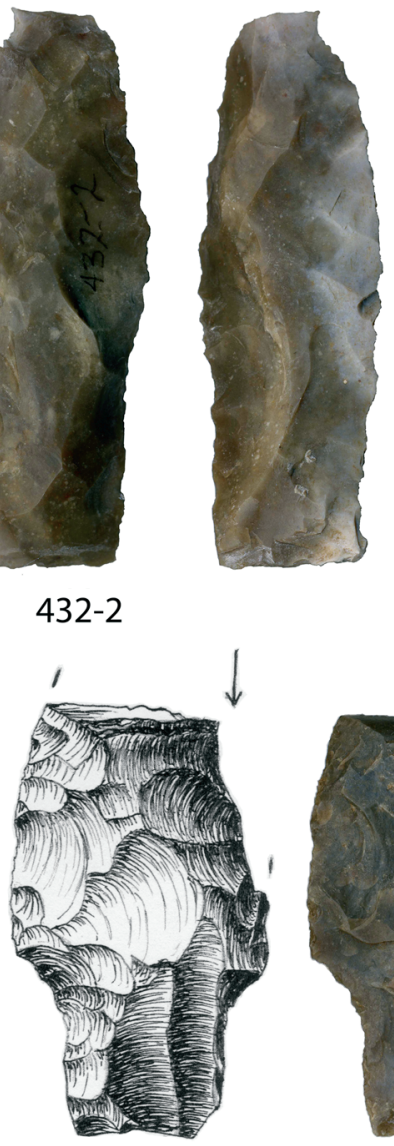
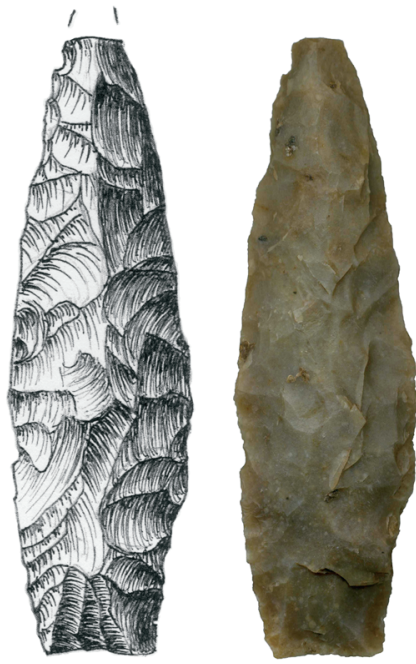

$305-2$
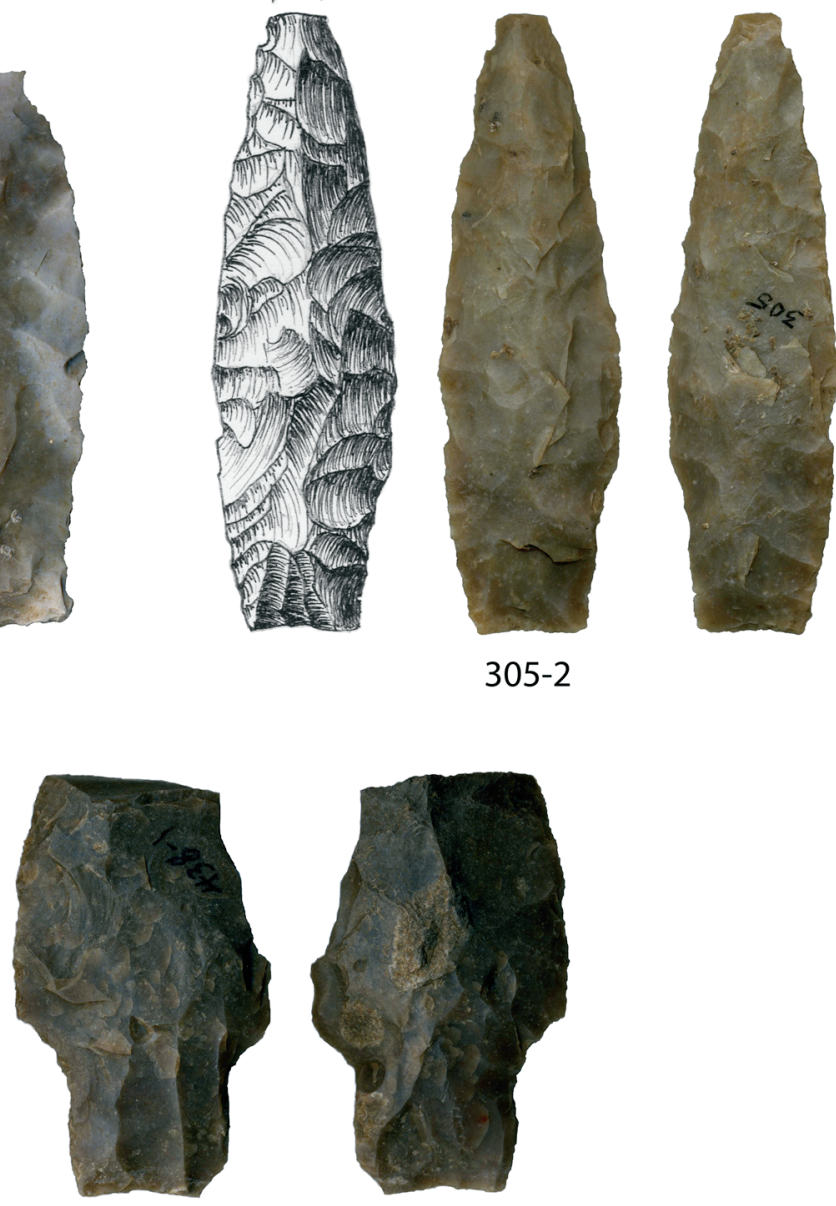

438-1

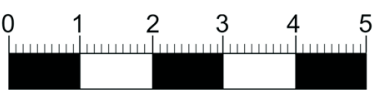

centimeters

Figure 7-6. Middle Archaic Travis projectile points. 


\section{Pedernales}

Phase: Round Rock

Series: Pecos

$\mathrm{n}=7$ (Specimen Nos. 54-2, 54-3, 204-19, 306-2, 306-3, 403-1, 432-1)

Condition and Breakage: Specimen 54-2 is nearly complete, missing its distal tip and one barb. The damaged edge has been resharpened all the way down to the stem. 54-3 is has thermal fracturing and impact damage around the base and shoulders. 306-3 has a transverse, bending snap fracture as well as some impact damage to one lateral edge, one shoulder and one basal ear (Figure 7-7 B). 204-19 is a proximal fragment with a medial snap fracture and snap damage to one barb and one basal ear. 306-2 is a proximal fragment with snap impact damage to the distal tip, one shoulder and one basal ear; the other shoulder has a burin fracture (Figure 7-8). One lateral edge of this specimen has a series of step terminations, either from crude retouching or crushing impact damage. 403-1 has a snap fracture that has removed all of one lateral edge and shoulder. None of the available points for this time period exhibit any clear flaking pattern. 432-1 exhibits a distal snap fracture and step terminations on both faces.

Retouch: All specimens have been retouched. 204-19 has retouch along the stem and around one shoulder where the barb should be.

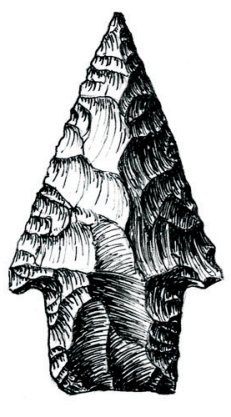

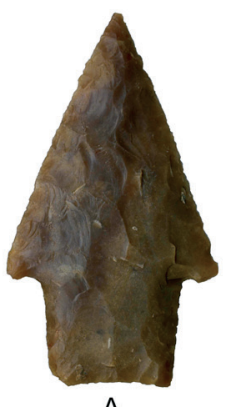

A

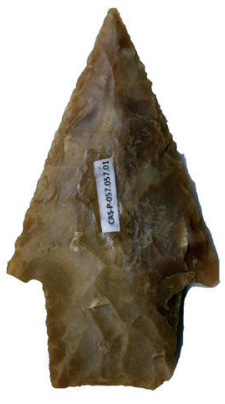

C

$54-3$

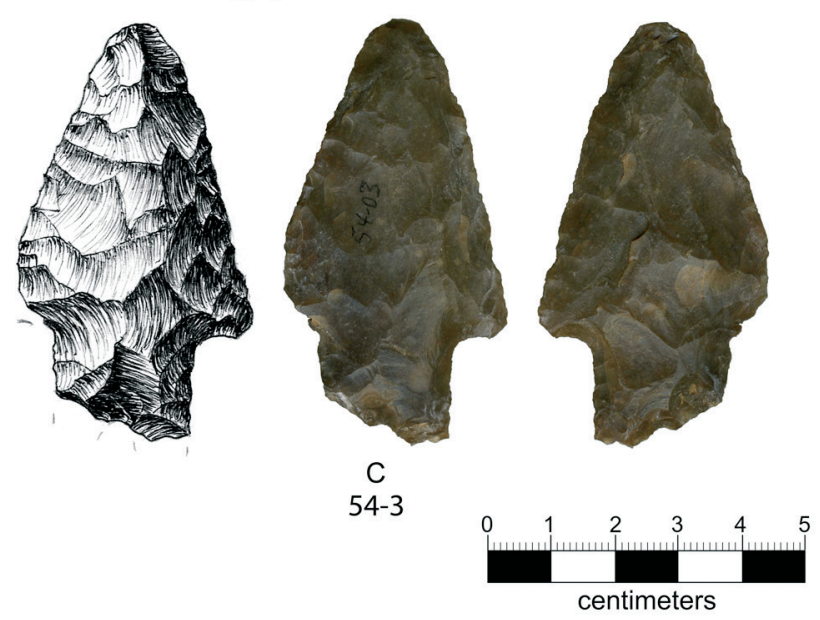

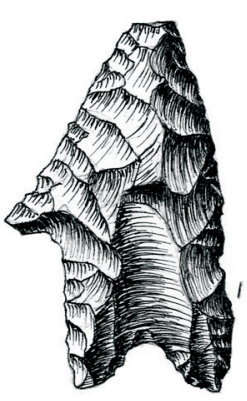

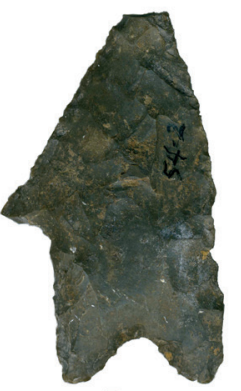

B 54-2
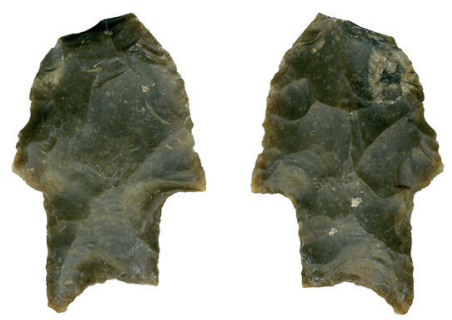

$306-3$

Figure 7-7. Late Archaic I (Bulverde and Pedernales) projectile points. 


\section{Chapter 7}

\section{Lange}

Phase: San Marcos

Series: NS

$\mathrm{n}=2($ Specimen Nos. 55-2, 305-1)

Condition and Breakage: Specimen 55-2 exhibits a distal snap and step terminations on one face, probably from impact. 305-1 has a distal snap with a spin-off step terminating fracture down one face and exhibits damage to one lateral edge and the stem (Figure 7-9).

Retouch: Both specimens exhibit retouch along the lateral edges.

\section{Late Archaic II}

\section{Castroville}

Phase: Uvalde

Series: Nueces

$\mathrm{n}=2$ (Specimen Nos. 7-2, 53-1)

Condition and Breakage: Specimen 7-2 exhibits random flake patterning and extensive retouch on one of the blade edges. Impact damage has removed a barb and a portion of
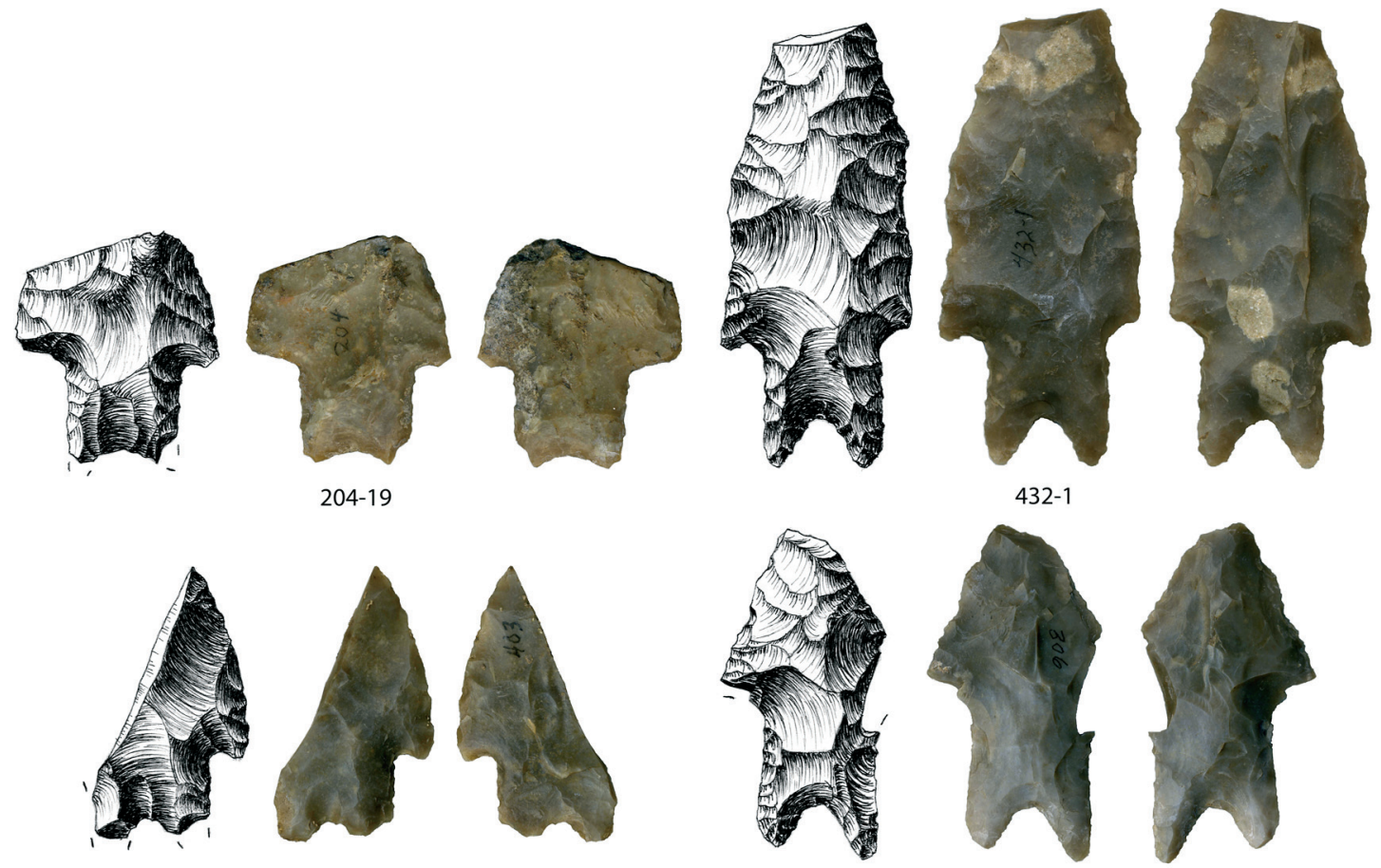

403-1

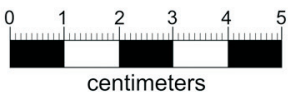

$306-2$

centimeters

Figure 7-8. Examples of Late Archaic I (Pedernales) projectile points. 


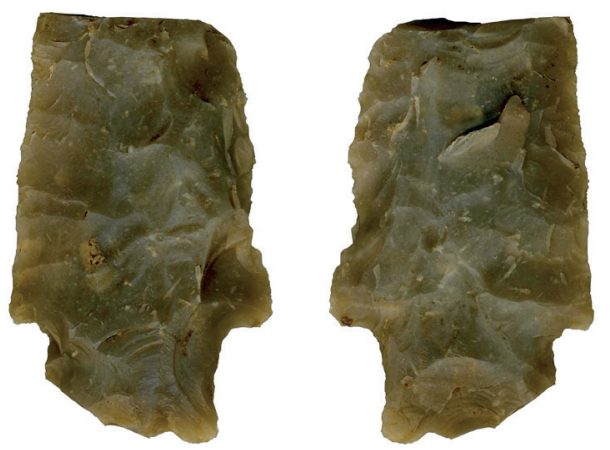

$305-1$
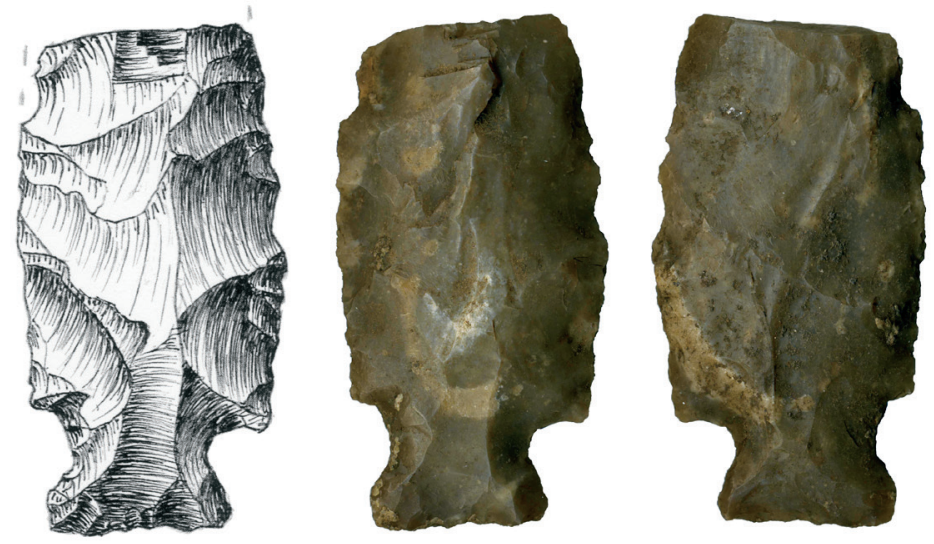

$55-2$

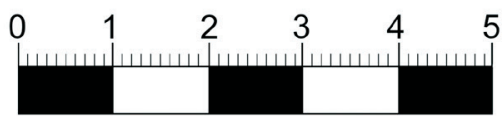

centimeters

Figure 7-9. Late Archaic I (Lange) projectile points.

the stem and base on one side. Specimen 53-1 has a medial snap and extensive thermal damage including fractures, pot lidding, and crazing (Figure 7-10).

Retouch: The base, stem and lateral edges of specimen 7-2 have been retouched.

\section{Late Archaic III}

\section{Ensor}

Phase: Twin Sisters

Series: Rio Bravo

$\mathrm{n}=1$ (Specimen No. 437-1)

Condition and Breakage: This specimen has a distal snap and lacks flake patterning. Its stem has been assymetrically resharpened (Figure 7-11 A)

Retouch: There is evidence of retouch along the basal and lateral edges. 

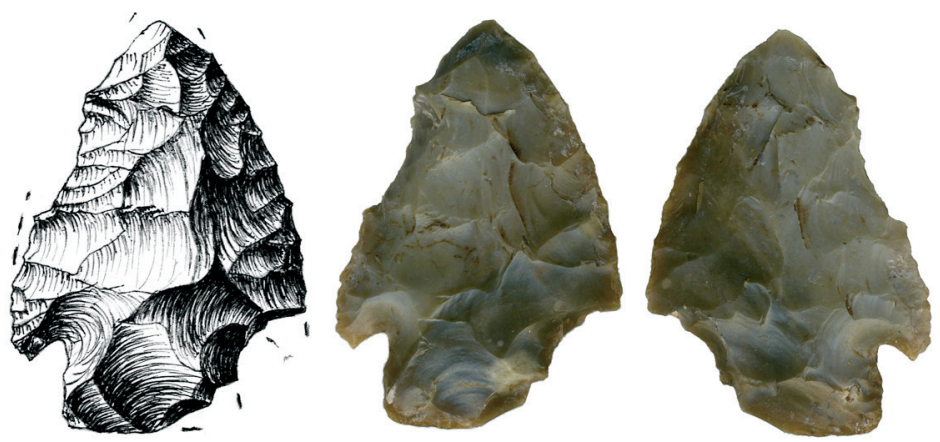

7-2
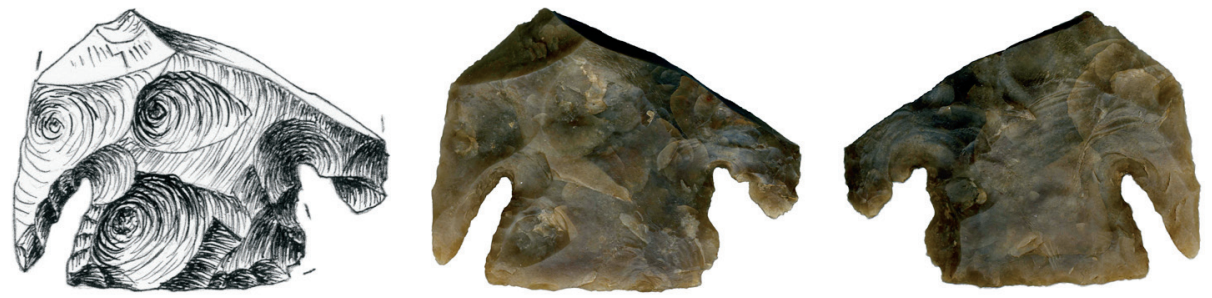

53-1

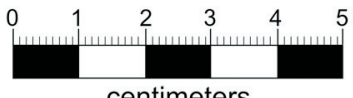

centimeters

Figure 7-10. Late Archaic II (Castroville) projectile points.

\section{Ellis}

Phase: Twin Sisters

Series: NS

$\mathrm{n}=1$ (Specimen No. 304-9)

Condition and Breakage: This flake pattern on this specimen approaches collateral, but the scars do not meet. There is a wedge shape break on one lateral edge, likely from thermal treatment (Figure 7-11 B). Retouch: Retouch was not observed on this specimen.

\section{Edgewood}

Phase: Twin Sisters

Series: NS

$\mathrm{n}=2$ (Specimen Nos. 304-12, 304-13)

Condition and Breakage: Specimen 304-12 has a distal snap and a thermal fracture that removed one lateral edge and barb. Specimen 304-13 is complete except for one missing shoulder barb, and is heavily resharpened. Both specimens exhibit random flake patterning (Figure 7-11 C and D). Retouch: Both specimens exhibit retouching along their lateral edges. 


\section{Fairland}

Phase: Twin Sisters

Series: Rio Bravo

$\mathrm{n}=1$ (Specimen No. 53-3)

Condition and Breakage: This specimen is heavily resharpened but mostly complete except for a small snap fracture on one basal ear. The base has been thinned with two flute-like flakes removed from one side; these end in a step termination. There is some crushing along the base and stem. It exhibits random flake patterning (Figure 7-11 E).

Retouch: The lateral edges and distal tip have been retouched.

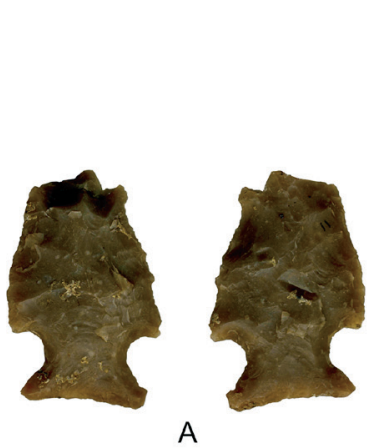

437-1
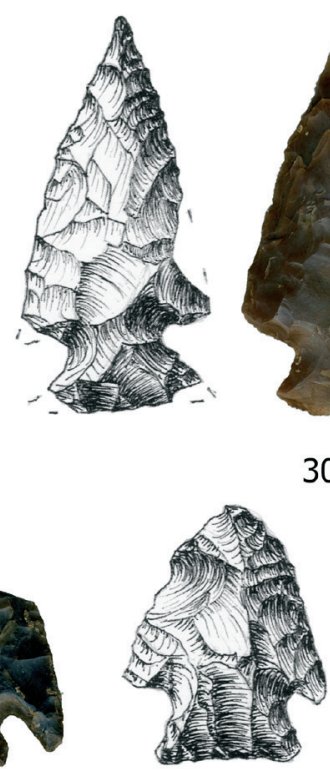

- $\mathrm{D}$

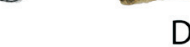

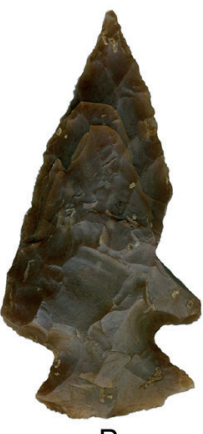

B
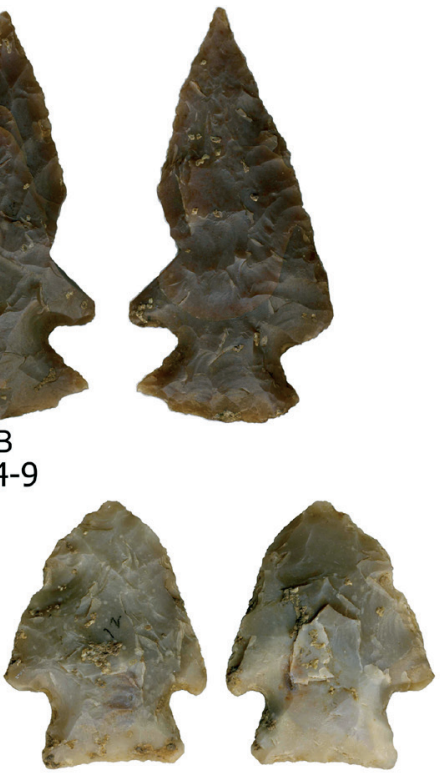

304-13

304-12
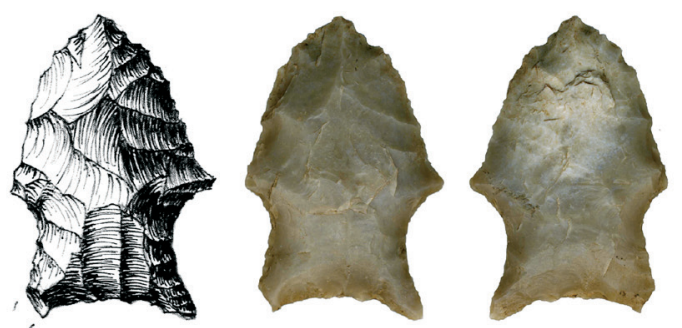

E

53-3

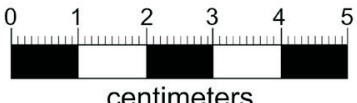

centimeters

Figure 7-11. Late Archaic III projectile points: (A) Ensor; (B) Ellis; (C, D) Edgewood; (E) Fairland. 
Transitional Archaic/Austin

\section{Darl}

Phase: Driftwood

Series: Kyle

$\mathrm{n}=1$ (Specimen No. 428-1)

Condition and Breakage: This specimen has a dramatic medial snap from heavy impact, and also a possible burin fracture that has removed most of the blade. The remaining stem and base exhibit alternate beveling, but lacks discernible flake patterning (Figure 7-12 A).

Retouch: Retouch is visible on the stem and basal edges.

\section{Scallorn}

Phase: Austin

Series: Austin

$\mathrm{n}=1$ (Specimen No. 431-1)

Condition and Breakage: This specimen has a snap break on one barb and one basal ear; there is slight damage to the distal tip. It exhibits random flake patterning and serrated lateral edges (Figure 7-12 B).

Retouch: The serrated lateral edges have been retouched.

\section{ТоYан}

\section{Perdiz}

Phase: Toyah

Series: Blum

$\mathrm{n}=3$ (Specimen Nos. 401-1, 201-7,104-25)

Condition and Breakage: Specimen 401-1 has a snap break at the stem. Some of the flaking on the blade approaches a collateral pattern. Specimen 201-7 is a mostly

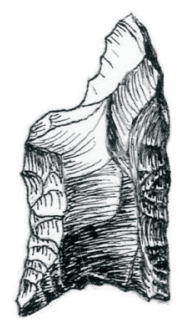

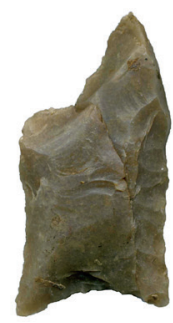

A

428-1
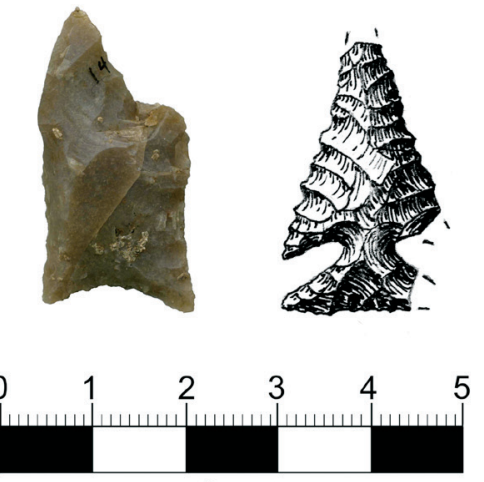

centimeters

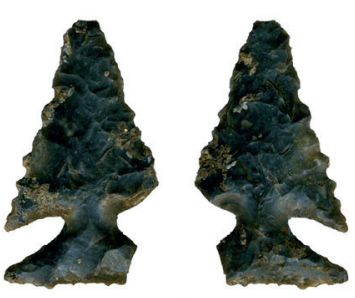

B

431-1

Figure 7-12. Transitional Archaic/Austin projectile points: (A) Darl; (B) Scallorn. 
complete specimen. It has serrated edges and random flake patterning. One face has very little flaking and this arrow point appears to have been made on a flake. Specimen 104-25 has a crushed tip and is missing one barb. The shoulders are strongly convex, with wide-flaring, sweeping barbs. All three Perdiz points are stylistically distinct from one another, and illustrate some of the variation that is to be seen within this common point type (Figure 7-13).

Retouch: All three specimens have retouch on the lateral edges.

\section{UNTYPED}

\section{Untypable Dart Points}

Phase: N/A

Series: N/A

$\mathrm{n}=15$ (Specimen Nos 412-7, 312-13, 304-11, 202-1, 431-2, 400-7, 6-1, 54-1, 405-1, 405-

13, 410-2, 407-3, 405-9, 411-2, 201-3)

Condition and Breakage: Only some specimens from this category are selected for description and illustration. Specimen $405-1$ is a complete specimen with a square stem, corner notching, and weak shoulders (Figure 7-14 A). Specimen 405-13 exhibits an expanding stem, steep alternate beveling; the un-beveled edges show a collateral flake pattern (Figure 7-14 B). Specimen 407-3 is mostly complete but badly burned. This point has a straight, square stem with weak shoulders. The tip is missing from a bend break, perhaps from impact. It resembles the Travis type (Figure 7-14 C). Specimen 411-2 also has a square stem and corner notching as well as convex lateral edges. The blade is beveled (R), characteristic of some Early Archaic types (Figure 7-14 D) (also Figure 7-15). Although this dart point is missing its tip, it is complete enough that it could be identified if it compared with any previously defined type categories. As it stands, this specimen seems to represent stylistic elaboration, perhaps experimentation, during the latter part of the Early Archaic.

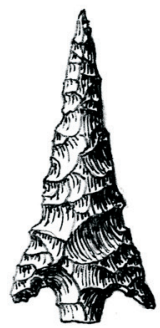

11

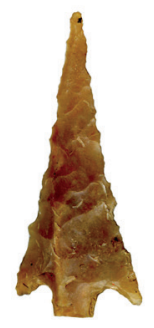

401-1

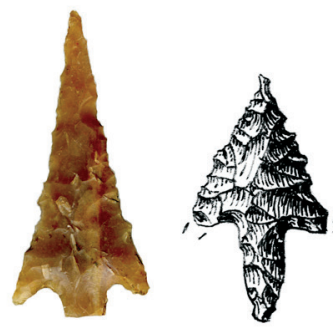

$$
0
$$

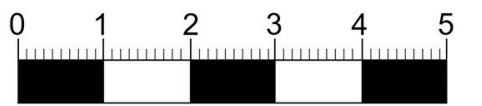

centimeters
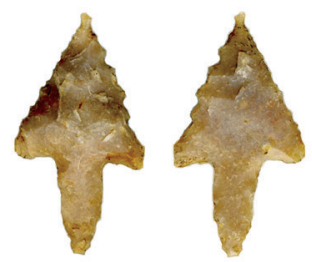

201-7

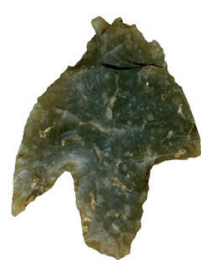

$104-25$

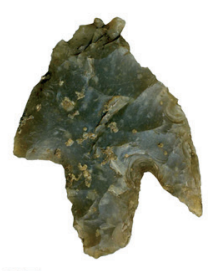




\section{Chapter 7}

\section{Untypable Arrow Points}

Phase: N/A

Series: N/A

$\mathrm{n}=1($ Specimen No. 55-1)

Condition and Breakage: Specimen 55-1 exhibits some notching along the base and irregular flake removals around the edges on one face; the other face has very little flaking and this artifact appears to have been made on a flake (Figure 7-16).

\section{Bifaces}

A total of 60 bifaces and biface fragments were recovered from data recovery and monitoring activities. Of those, 37 (61.7\%) were recovered from Units 3 and 4. Our analysis focuses on describing and tabulating the dimensions, form, and fragmentation types of the bifaces (Table 7-2). A full listing of the all the recovered bifaces appears in Appendices B and C. Artifacts from Units 1 and 2 are excluded from these analyses because these units had been disturbed by the installation of a gas line.
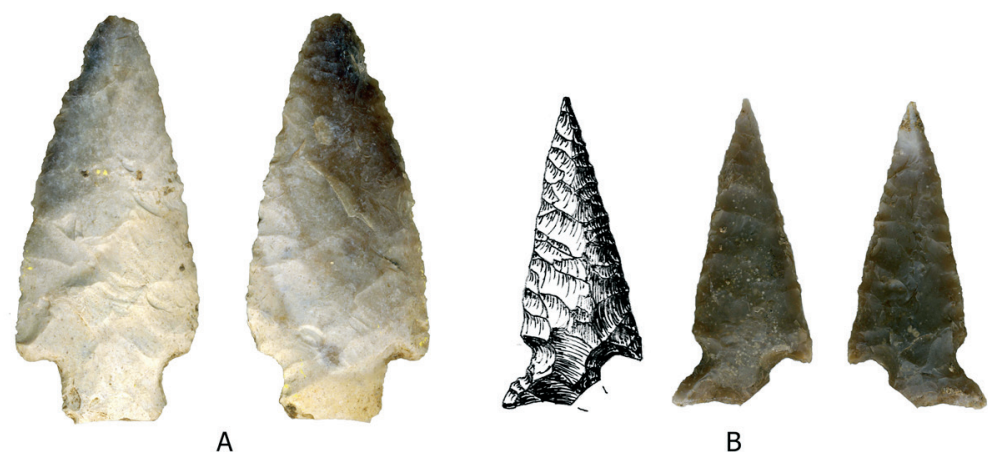

A 405-13

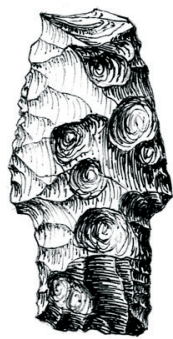

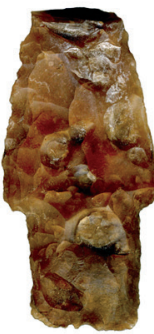

C

$407-3$
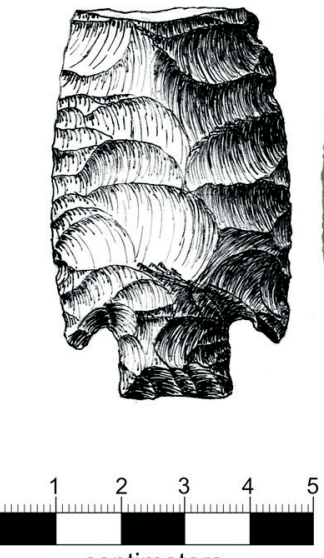

centimeters

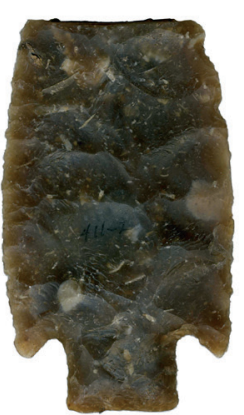

$\mathrm{D}$

$411-2$
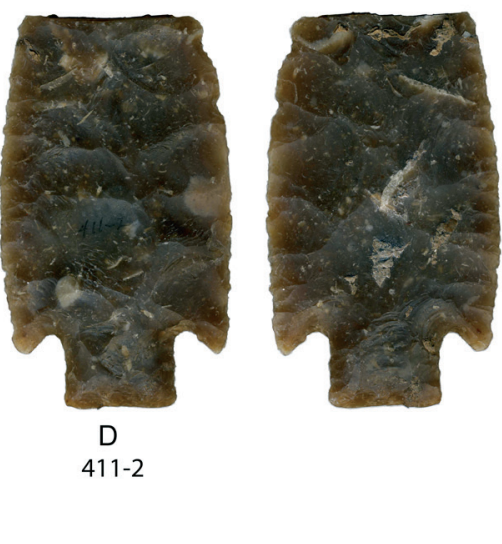

Figure 7-14. Examples of untypable dart points. 


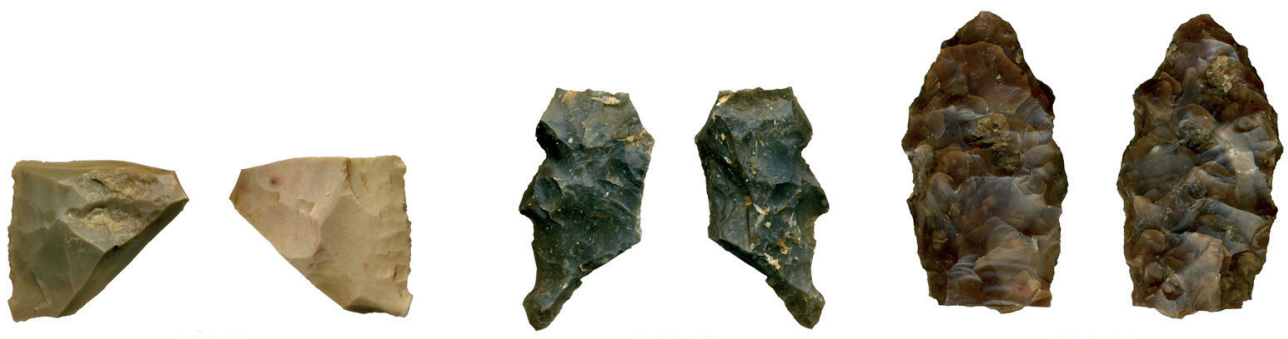

412-7

312-13

304-11

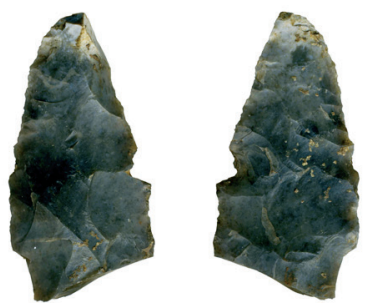

202-1

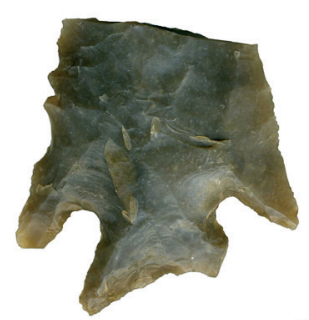

431-2
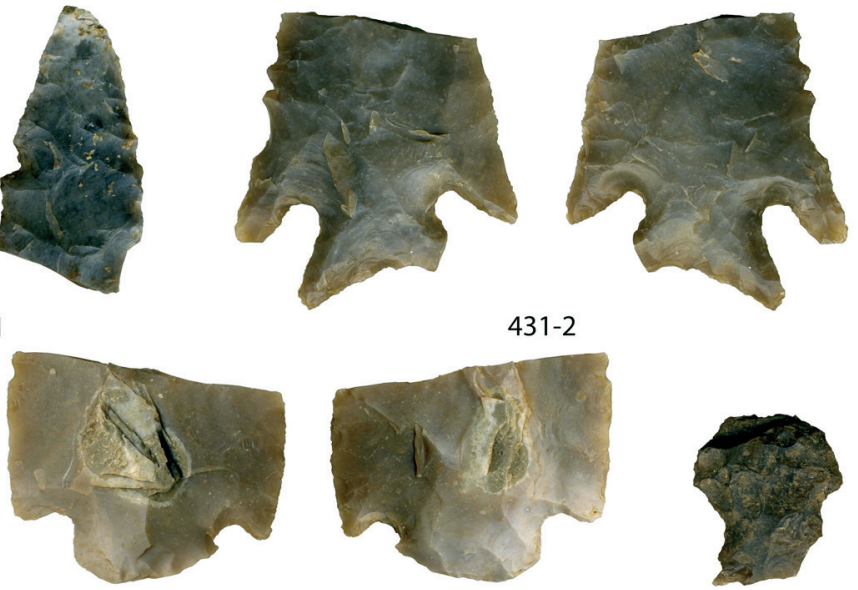

6-1
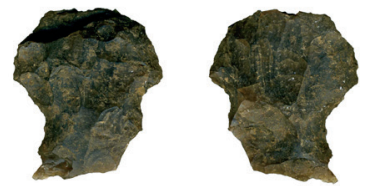

400-7

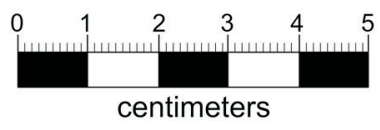

54-1

Figure 7-15. Examples of untypable dart point fragments.

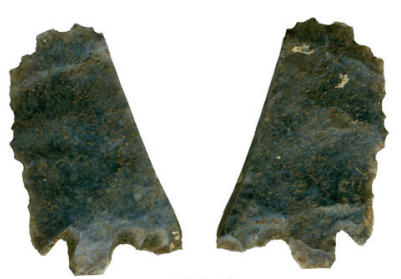

55-1

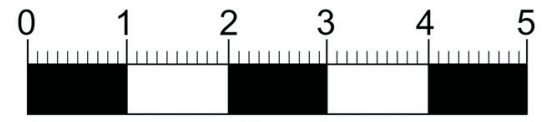

centimeters

Figure 7-16. Untypable arrow point fragment. 
Table 7-2. Bifaces from Units 3 and 4

\begin{tabular}{|c|c|c|c|c|c|c|}
\hline $\begin{array}{l}\text { Spec } \\
\text { No. }\end{array}$ & Form & Fragmentation & $\begin{array}{c}\text { Length } \\
(\mathrm{mm})\end{array}$ & $\begin{array}{c}\text { Width } \\
(\mathrm{mm})\end{array}$ & $\begin{array}{c}\text { Thickness } \\
\text { (mm) }\end{array}$ & $\begin{array}{c}\text { Weight } \\
\text { (g) }\end{array}$ \\
\hline $401-3$ & Ovate & Complete & 55.8 & 41.37 & 10.84 & 22.8 \\
\hline $404-1$ & Ovate & Complete & 61.87 & 42.97 & 14.12 & 32 \\
\hline $316-3$ & Ovate & End only & & & 9.38 & 15 \\
\hline $306-7$ & Ovate & End only & & & 15.95 & 52.4 \\
\hline $409-12$ & Ovate & End only & & & 10.81 & 31.2 \\
\hline $313-1$ & Lanceolate & End only: Proximal & & 31.85 & 8.63 & 14.5 \\
\hline $304-2$ & Lanceolate & End only: Proximal & & 42.92 & 8.08 & 19.7 \\
\hline $407-10$ & Lanceolate & End only: Proximal & & 44.55 & 11.16 & 27.4 \\
\hline $409-8$ & Lanceolate & End only: Proximal & & 47.36 & 13.90 & 22.4 \\
\hline $313-41$ & Lanceolate & End only: Proximal & & 40.69 & 12.11 & 18.0 \\
\hline $405-3$ & Lanceolate & End only: Proximal & & 46.91 & 8.84 & 15.5 \\
\hline $308-6$ & Lanceolate & End only: Proximal & & 40.27 & 14.09 & 22.8 \\
\hline $328-1$ & Indeterminate & End only: Distal & & & 10.25 & 27.3 \\
\hline $411-1$ & Indeterminate & End only: Distal & & & 8.41 & 13.2 \\
\hline $403-2$ & Indeterminate & End only: Distal & & & 5.55 & 5.3 \\
\hline $412-2$ & Indeterminate & End only: Distal & & & 12.26 & 26.5 \\
\hline $315-17$ & Indeterminate & End only: Distal & & & 6.93 & 1.9 \\
\hline $312-7$ & Indeterminate & End only: Distal & & & 9.18 & 20.7 \\
\hline $409-13$ & Indeterminate & End only: Distal & & & 7.99 & 5.7 \\
\hline $407-2$ & Indeterminate & End only: Distal & & & 8.90 & 8.3 \\
\hline $430-2$ & Indeterminate & End only: Distal & & & 9.62 & 17.6 \\
\hline $414-16$ & Indeterminate & End only: Distal & & & 12.77 & 13.2 \\
\hline $403-3$ & Indeterminate & End only: Distal & & & 8.06 & 13.6 \\
\hline $407-15$ & Indeterminate & End only: Distal & & & 5.74 & 2.9 \\
\hline $308-44$ & Indeterminate & Medial & & 43.38 & 12.68 & 32.3 \\
\hline $339-1$ & Indeterminate & Medial & & & 8.90 & 16.0 \\
\hline $414-19$ & Indeterminate & Medial & & & 14.02 & 25.5 \\
\hline $409-10$ & Indeterminate & Medial & & & 9.01 & 15.9 \\
\hline $407-9$ & Indeterminate & Medial & & & 12.37 & 17.5 \\
\hline $313-19$ & Indeterminate & Medial & & & 11.32 & 16.0 \\
\hline $411-3$ & Indeterminate & Medial & & & 9.05 & 14.5 \\
\hline $314-4$ & Indeterminate & Medial & & & 5.97 & 3.3 \\
\hline $404-3$ & Indeterminate & Medial & & & 6.74 & 7.2 \\
\hline $408-4$ & Indeterminate & $\begin{array}{l}\text { Medial: } \\
\text { Edge Fragment }\end{array}$ & & & 6.54 & 1.4 \\
\hline
\end{tabular}


Table 7-2. Bifaces from Units 3 and 4

\begin{tabular}{cclcccc}
\hline $\begin{array}{c}\text { Spec } \\
\text { No. }\end{array}$ & Form & Fragmentation & $\begin{array}{c}\text { Length } \\
\mathbf{( m m )}\end{array}$ & $\begin{array}{c}\text { Width } \\
\mathbf{( m m})\end{array}$ & $\begin{array}{c}\text { Thickness } \\
\mathbf{( m m})\end{array}$ & $\begin{array}{c}\text { Weight } \\
\mathbf{( g )}\end{array}$ \\
\hline $305-48$ & Indeterminate & $\begin{array}{l}\text { Medial: } \\
\text { Edge Fragment }\end{array}$ & & & 11.75 & 10.4 \\
$412-1$ & Indeterminate & $\begin{array}{l}\text { Medial: } \\
\text { Edge Fragment }\end{array}$ & & & & \\
& & & & & & \\
\hline
\end{tabular}

Only two of the 35 bifaces recovered from the two undisturbed units were complete. All bifaces from these units were sorted into four morphological categories: ovate $(n=3)$, pointed ovate $(n=2)$, lanceolate $(n=7)$ or indeterminate $(n=23)$. Ovate bifaces are characterized by rounded or bi-convex lateral edges and weakly defined proximal and distal ends. Pointed-ovate bifaces exhibit rounded or convex bases with a pointed blade creating a defined distal tip. Lanceolate bifaces have parallel to bi-convex margins, squared bases and defined, converging distal tips. In addition, late-stage lanceolate bifaces exhibit marginal retouch, performed to shape and straighten the lateral edges (Lohse et al. 2013). The indeterminate category was used for incomplete specimens lacking attributes necessary for classification. Incomplete bifaces were identified as corner fragments, medial fragments, end missing, end only (proximal or distal) or edge fragment or edge missing. Complete artifacts were measured for length, width, and thickness to the nearest $0.1 \mathrm{~mm}$ and then weighed to the nearest $0.1 \mathrm{~g}$. Length and width measurements were not considered to be useful for smaller fragments.

\section{Ovate Bifaces $(n=3)$}

The three specimens in this category are rounded end fragments. Due to the symmetrical shape of ovate bifaces, end fragments cannot be accurately identified as either proximal or distal. Specimens 409-12 and 306-7 have transverse fractures with hinge terminations (Figure 7-17 A, B). Specimen 316-3 has an irregular fracture which seems to have resulted from a lateral biface thinning failure, but does not represent a true perverse fracture (Figure 7-17 C). These artifacts probably reflect failed biface production resulting from knapping or flaking mistakes. Given the small sample included in this excavation, no meaningful conclusions should be drawn about the nature or frequency of this activity, at least at this location.

Pointed Ovate Bifaces $(n=2)$

Both specimens in this category are complete. Specimen 401-3 has macroscopic use wear and crushing damage to both the proximal and distal ends as well as discoloration from heat treatment (Figure 7-18 A). Specimen 404-1 is thicker, crudely flaked on one face, and exhibits patination that has been flaked through (Figure 7-18 B). Both specimens have slightly or somewhat sinuous lateral edges, reflecting that final edge-shaping had not yet been completed (this is more true for Specimen 404-1), and flake removals with step terminations. 
Chapter 7

\section{Lanceolate Bifaces $(n=7)$}

All of the specimens in this category are proximal fragments with squared bases, a key difference between lanceolate and ovate bifaces (Figure 7-19). Specimens 304-2, 405-3 and 313-
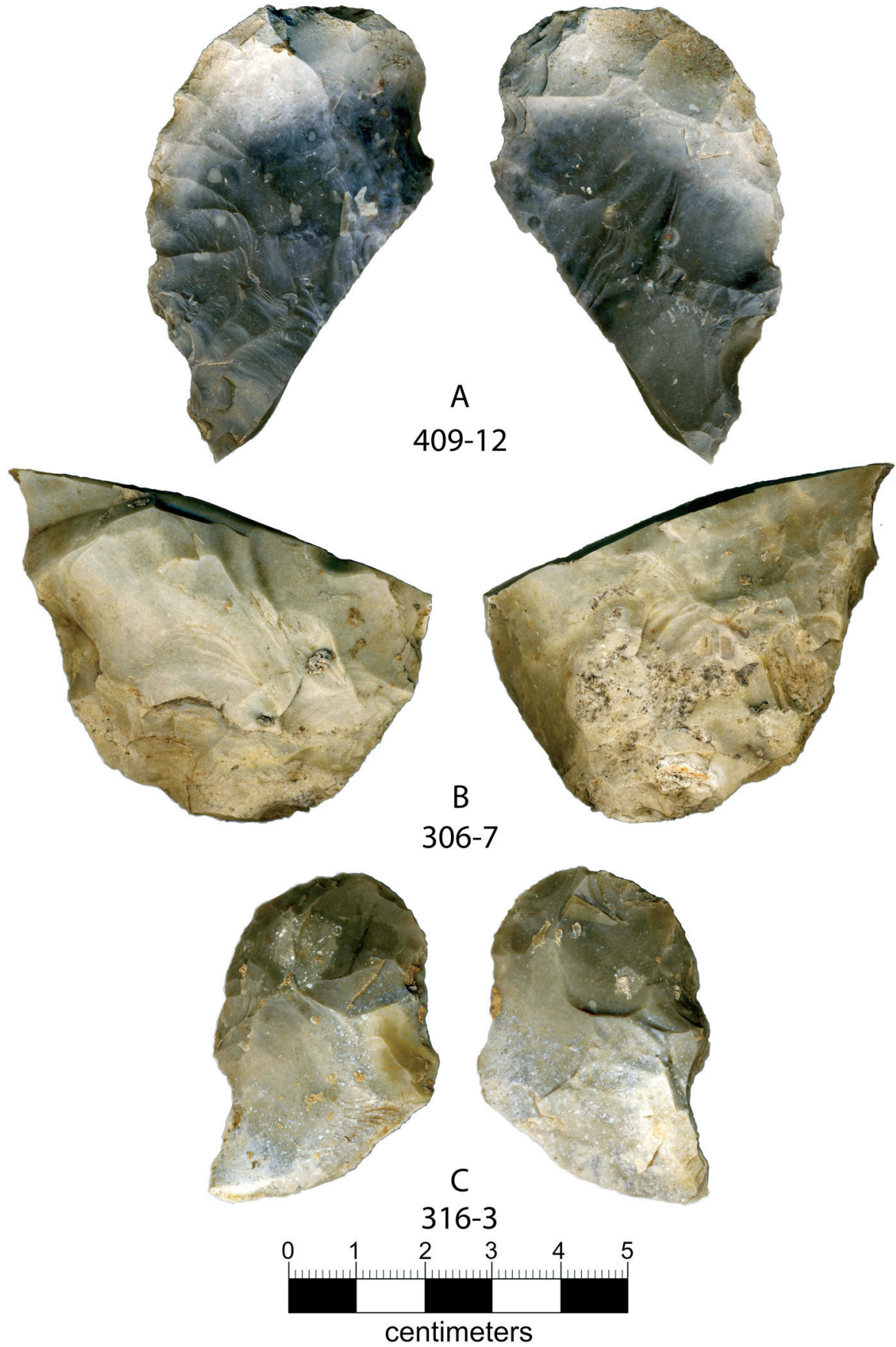

Figure 7-17. Ovate bifaces. 
1 are late-stage bifaces (Figure 7-19 A-C). They are thin, have no cortex, and exhibit numerous flake scars, including marginal retouch. Overall, this category of biface represents middle-tolate-stage biface thinning and manufacturing. However, as with the other categories, the small excavated sample precludes any meaningful conclusions about this and related activities at this locale.
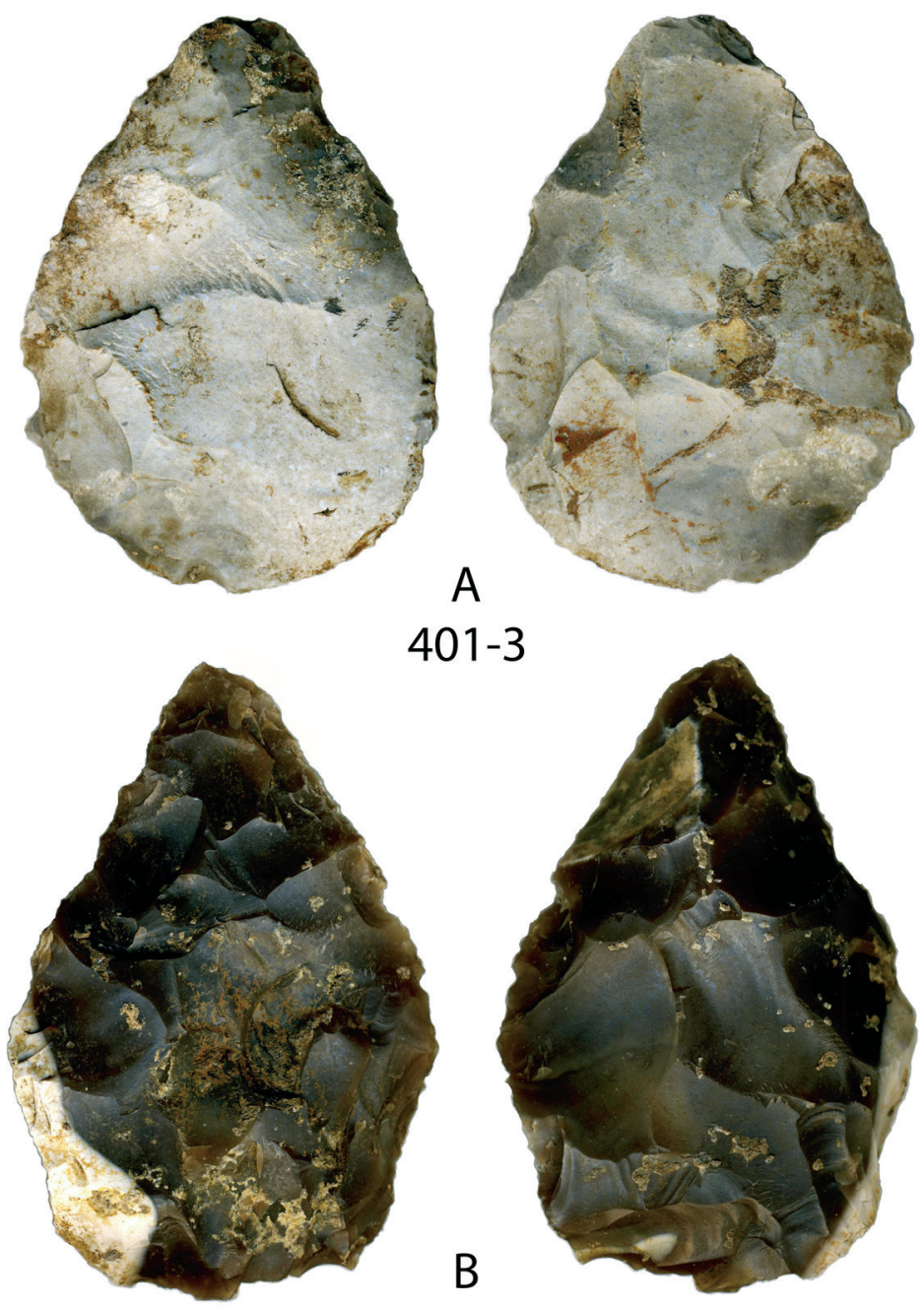

404-1

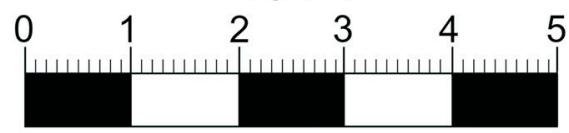

centimeters

Figure 7-18. Pointed ovate bifaces. 


\section{Chapter 7}

\section{Indeterminate Bifaces $(n=23)$}

Bifaces with indeterminate forms were sorted into categories based on fragmentation, including distal fragments $(n=12)$, medial fragments $(n=9)$, and medial edge fragments $(n=3)$. None of the distal fragments came from late stage bifaces. Specimen 403-3 has typical flake removals on one face, but the other face is smooth with only marginal retouch (Figure 7-20 A). Similarly 328-1, has numerous flake scars on one face, but very few on the other (Figure 7-19 B). Specimens 409-13 and 403-2 have thermal damage, including thermal fractures (Figure 7-19 C, D). The fractures on the remaining distal fragments all appear to be transverse breaks.

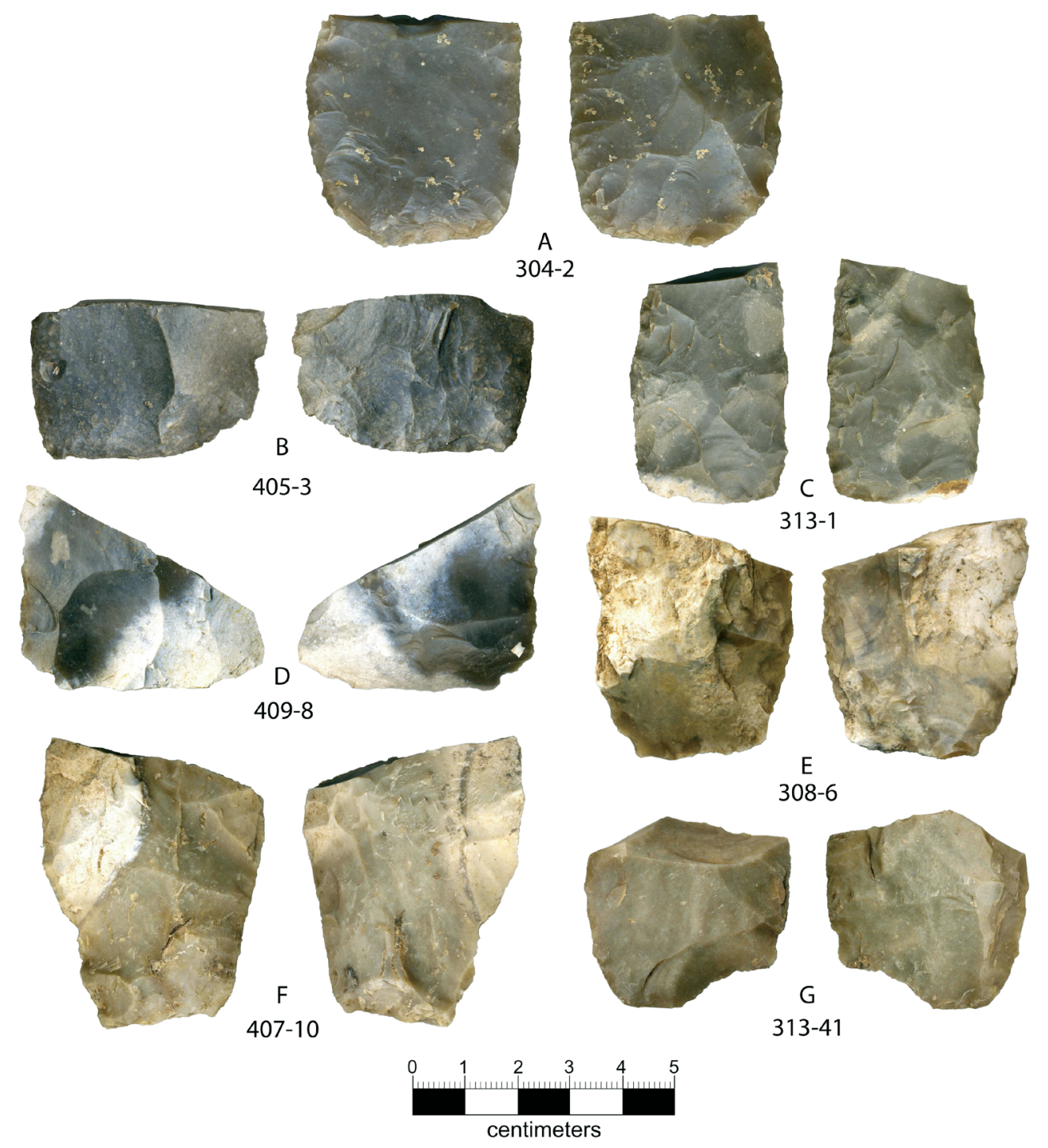

Figure 7-19. Lanceolate bifaces. 
Among the medial fragments is one specimen from a late-stage biface, specimen 411-3 (Figure 7-21 A). The marginal retouch on this specimen is characterized by thin, parallel soft hammer or even pressure flake scars. Specimen 339-1 (Figure 7-21 B) also exhibits some retouch overlying larger flake scars but has cortex remaining on one face. Several of these specimens, such as 313-19 and 314-4 (Figure 7-21 C, E) have significant thermal damage.

Of the three edge fragments, one is a burin spall (specimen 412-1) and one is the distal end of an overshot flake (specimen 305-48; Figure 7-22 B). Specimen 408-4 is an edge fragment with a snap fracture; however it is difficult to determine what edge of the biface it was detached from (Figure 7-22 C).

\section{Unifaces and Flake Tools}

Formal unifaces are flaked only on one side and assume a standardized form. In the process of accomplishing this standardized form, prehistoric tool makers modified the original morphology of the flake to the extent that its initial size and shape cannot be determined (Hall et al. 1982:348). Conversely, flake tools include any flake that is edge-modified or used and that has little to no modification on its ventral face. These tools are also flaked only on one side, but do not assume standardized forms; they are considered expedient tools that can be easily prepared but that have relatively low reliability. Expedient flake tools are infrequently maintained and often discarded and replaced with a new tool when they attain an undesirable amount of wear.

All chipped stone from Units 3 and 4 were scanned for unifaces and flake tools. Specimens were classified as a flake tool if they showed evidence of having been modified or utilized and it the original flake morphology could be determined, at least to a degree. A specimen was classified as a minimally retouched uniface (MRU) if regular and intentional flaking (retouch) was evident on one or more of its edges, but its original flake form was still distinguishable. A uniface was designated as formal if it exhibited significant shaping and deliberate patterning of unifacial flake removals on one or more edge. Table 7-3 lists the flake tools, MRUs and unifaces from Units 3 and 4 by unit and level. Of interest is that nine of 21 (42.8\%) of these artifacts came from Levels 13-15, corresponding with what appears to be the Calf Creek component at this locale.

Table 7-3. Flake Tools MRUs and Unifaces from Units $\mathbf{3}$ and $\mathbf{4}$

(All four formal unifaces are proximal scraper fragments.)

\begin{tabular}{ccccc}
\hline Spec No. & Unit & Level (Elevation cmbd) & Category & Weight (g) \\
\hline $304-10$ & 3 & $5(65-75)$ & Graver & 9.8 \\
$306-10$ & 3 & $7(85-95)$ & Flake Tool & 19.4 \\
$307-2$ & 3 & $8(95-105)$ & MRU & 3.2 \\
$308-43$ & 3 & $9(105-115)$ & MRU & 54.2 \\
$309-2$ & 3 & $10(115-125)$ & Flake Tool & 3.2
\end{tabular}


Table 7-3. Flake Tools MRUs and Unifaces from Units 3 and 4

(All four formal unifaces are proximal scraper fragments.)

\begin{tabular}{ccccc}
\hline Spec No. & Unit & Level (Elevation cmbd) & Category & Weight (g) \\
\hline $312-32$ & 3 & $13(145-155)$ & Formal Uniface & 9.5 \\
$314-28$ & 3 & $15(165-175)$ & Formal Uniface & 12.3 \\
$324-4$ & 3 & $25(265-275)$ & MRU & 5.4 \\
$429-1$ & 4 & $1-9(25-119)$ & MRU & 17.4 \\
$409-11$ & 4 & $10(115-125)$ & Flake Tool & 29.9 \\
$411-27$ & 4 & $12(135-145)$ & MRU & 45.0 \\
$411-28$ & 4 & $12(135-145)$ & MRU & 47.6 \\
$412-9$ & 4 & $13(145-155)$ & Formal Uniface & 9.8 \\
$413-20$ & 4 & $14(155-165)$ & Graver Fragment & 0.5 \\
$414-1$ & 4 & $15(165-175)$ & Flake Tool & 5.5 \\
$414-2$ & 4 & $15(165-175)$ & Formal Uniface & 11.6 \\
$414-3$ & 4 & $15(165-175)$ & MRU & 8.7 \\
$414-4$ & 4 & $15(165-175)$ & Flake Tool & 10.6 \\
$414-5$ & 4 & $15(165-175)$ & Awl & 7.9 \\
$415-5$ & 4 & $16(175-185)$ & MRU & 11.5 \\
$420-7$ & 4 & $21(225-235)$ & Flake Tool & 9.5 \\
\hline
\end{tabular}

A total of six flake tools (Figure 7-23) and eight MRUs (Figure 7-24) were identified within the collection. As with the biface artifact category, the excavated sample is deemed too small to substantiate meaningful conclusions or interpretations regarding any activities that these artifacts might indicate. However, with respect to the Calf Creek component that was sampled, four edge modified specimens were identified as possibly representing the proximal or haft element of scrapers (Figure 7-25). The term scraper is a functional classification commonly used to describe a tool that has been altered on one side to create an angled edge for "scraping." Clearly, without the distal or bit end, this functional determination cannot be substantiated. However, each candidate displays a bending break across their medial surface, and also shows evidence of having been modified through retouch flaking along both lateral edges. One specimen in particular, 412-9, has notches on opposing lateral edges. All are wedge-shaped in plan view and have triangular cross sections.

In addition to flake tools and unifaces, one graver, one graver fragment and one awl were identified (Figure 7-26). Specimen 304-10 is a chert flake with two edges that have been modified into gravers (Figure 7-26 C).

\section{Flake Cores}

Nine flake cores were recovered from Units 3 and 4 (Table 7-4). The definition for a flake core follows the description by Sitters et al. (2011:300): objects that show at least three flake 

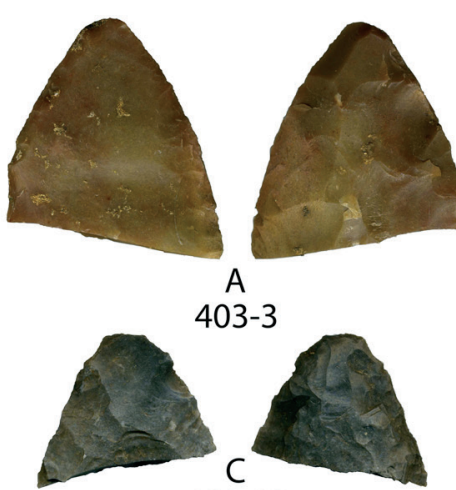

409-13
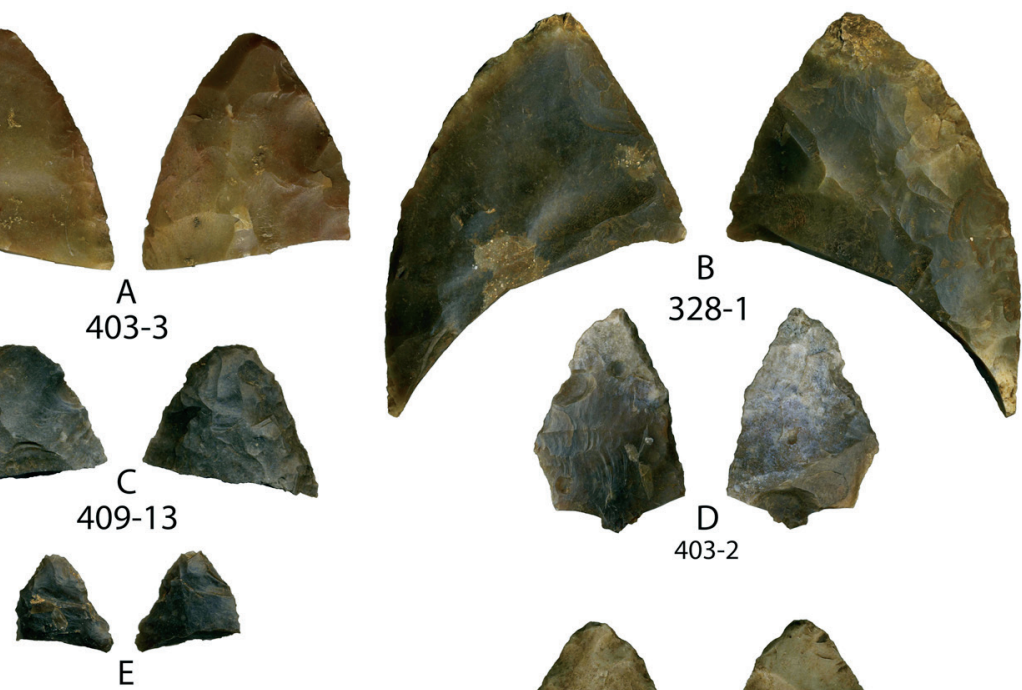

315-17
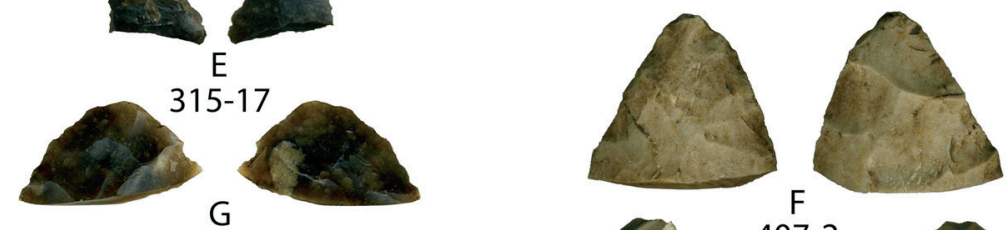

G
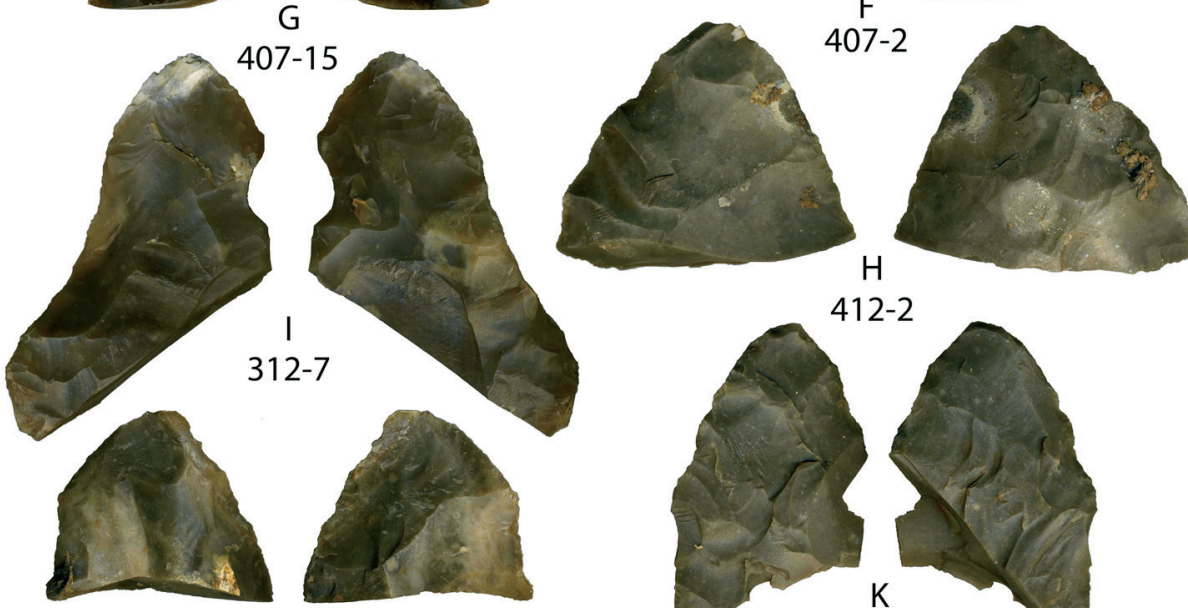

I
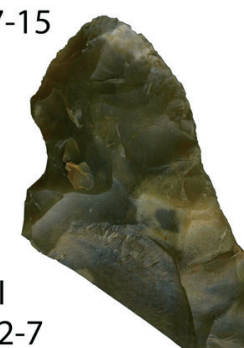

2-7

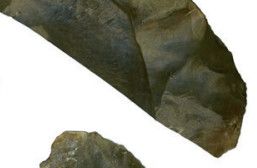

412-2

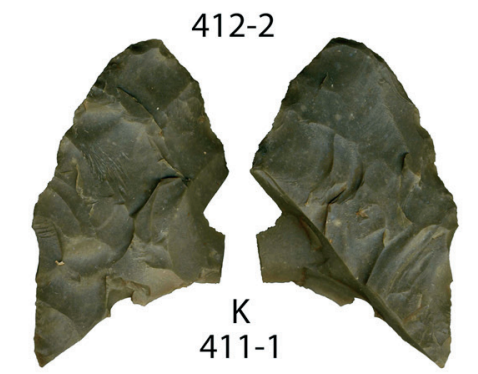

414-16

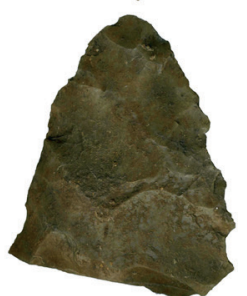

430-2

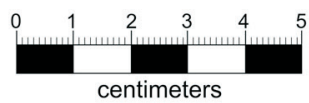

Figure 7-20. Examples of distal biface fragments of indeterminate bifaces. 

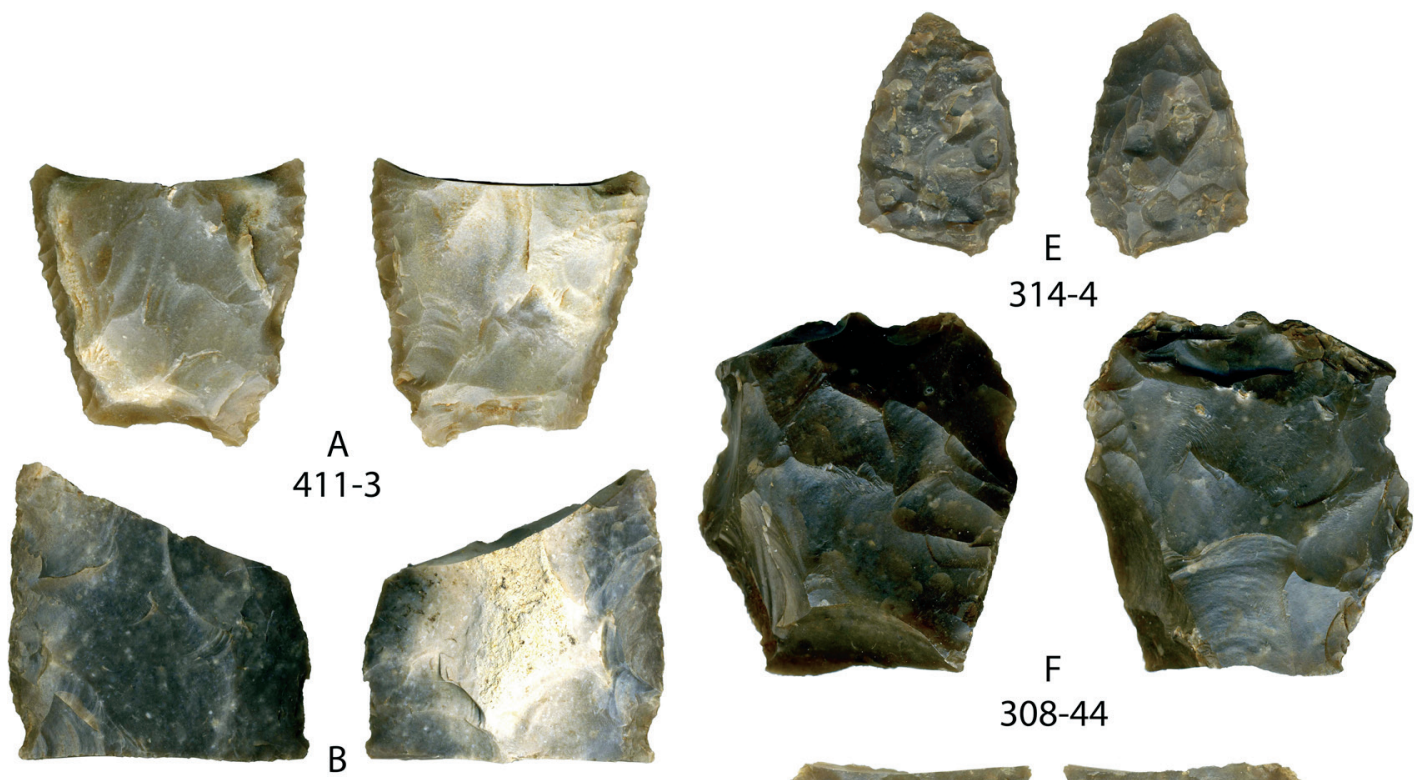

339-1
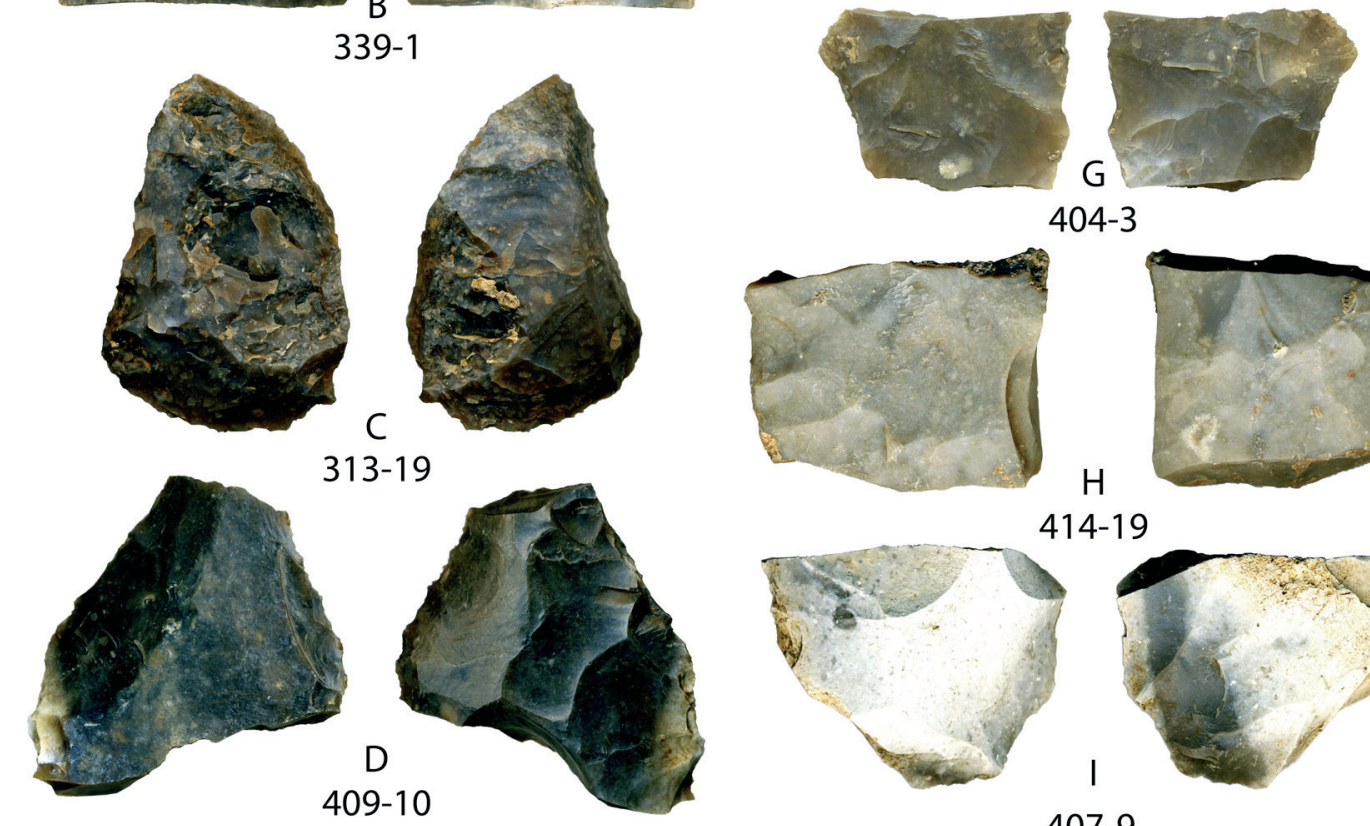

308-44
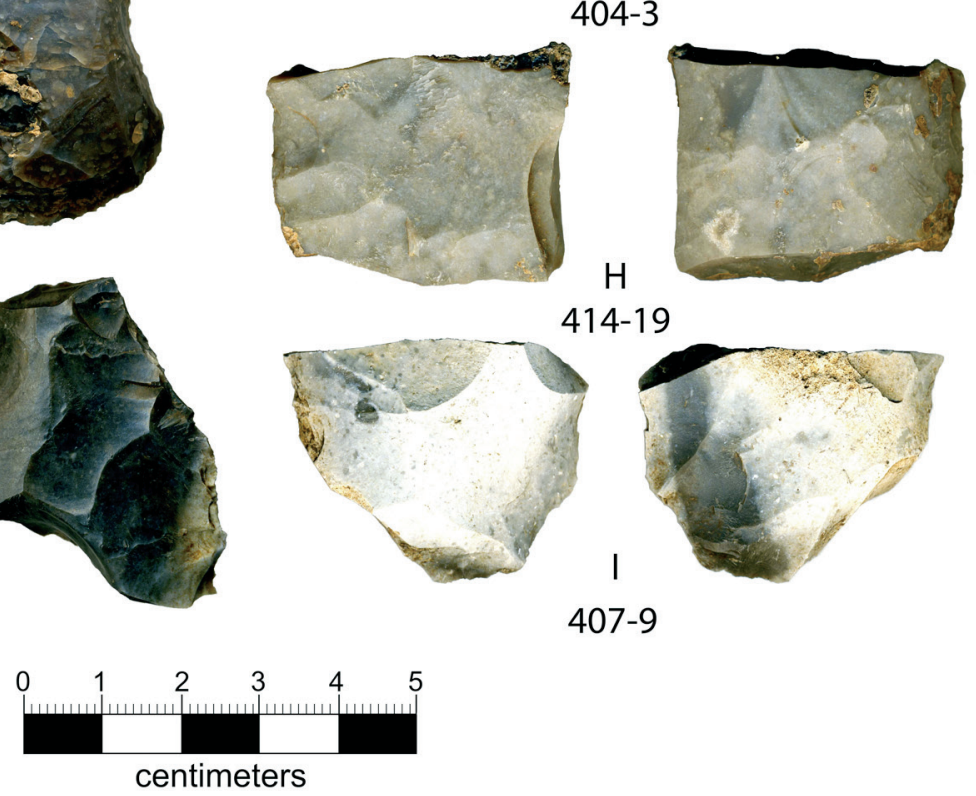

Figure 7-21. Examples of medial fragments of indeterminate bifaces. 


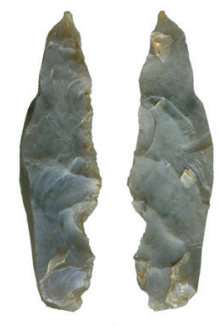

A

$412-1$

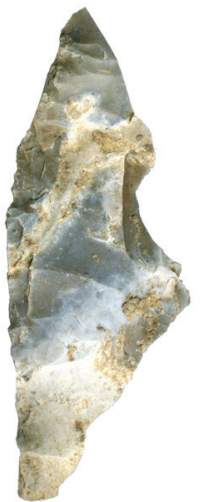

B

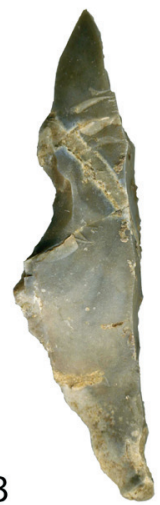

$305-48$

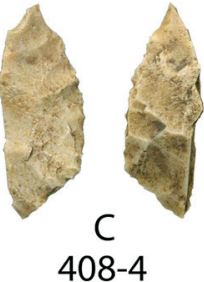

$408-4$

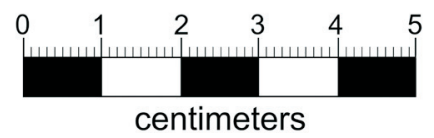

Figure 7-22. Examples of edge fragments of indeterminate bifaces.

removals or attempted removals from a discernible platform(s). Cores were sorted into one of 5 categories based on flake scar direction: unidirectional, bidirectional, multidirectional, ad hoc, or indeterminate. Unidirectional cores exhibit flake removals aligned in approximately the same direction from a common platform. Cores with two opposing faces that both share the same platform edge are categorized as bidirectional cores. Multidirectional cores are characterized by flake removals from multiple directions and from more than one platform. Ad hoc cores are a subcategory of multidirectional flake cores that show some rotation but no patterned faces or platforms have been developed. They also have little to no platform maintenance and some flake removals appear exploratory in nature. In larger samples where technological variation between flake core strategies can be well documented, characterizing the approaches taken to designing and maintaining a productive flake core can help archaeologists understand aspects of residential mobility, conservation strategies for using raw material, and possibly even standardized approaches to striking flakes for use as tools.

Table 7-4. Flake Cores from Excavation Units 3 and 4

\begin{tabular}{rrrcc}
\hline Spec No. & Unit & $\begin{array}{c}\text { Level } \\
\text { (Elevation cmbd) }\end{array}$ & Category & Weight (g) \\
\hline $308-7$ & 3 & $9(105-115)$ & indeterminate & 35.8 \\
$326-5$ & 3 & $27(285-295)$ & multidirectional, fragment & 50.2 \\
$327-3$ & 3 & $28(295-300)$ & multidirectional, exhausted & 32.9 \\
$400-8$ & 4 & $1(25-35)$ & multidirectional & 249.0 \\
$403-7$ & 4 & $4(55-65)$ & multidirectional & 130.1 \\
$403-47$ & 4 & $4(55-65)$ & bidirectional & 363.0 \\
$409-9$ & 4 & $10(115-125)$ & unidirectional & 383.3 \\
$412-22$ & 4 & $13(145-155)$ & bidirectional, exhausted & 52.0 \\
$418-2$ & 4 & $19(205-215)$ & multidirectional, ad hoc & 69.3 \\
\hline
\end{tabular}




\section{Chapter 7}

\section{Unidirectional $(n=1)$}

Specimen 409-9 is a relatively large flake core with two large flakes scars removed to set up a platform. This platform has four smaller flake scars all aligned in the same direction (Figure 7-27). The relationship between striking platform and productive core face is reminiscent of some prismatic blade cores, particularly of Clovis or Late Prehistoric Toyah assemblages. However, none of the flake scars have the necessary length-to-width ratio (at least 2:1) to be characterized as actual blades.

\section{Bidirectional $(n=2)$}

Specimen 403-47 has one platform edge with alternating flake removals creating two opposing faces (Figure 7-28 A). Specimen 412-22 is an exhausted flake core (Figure 7-28 B). Exhausted cores are smaller in size, have smaller flake scars and have been reduced to the point of

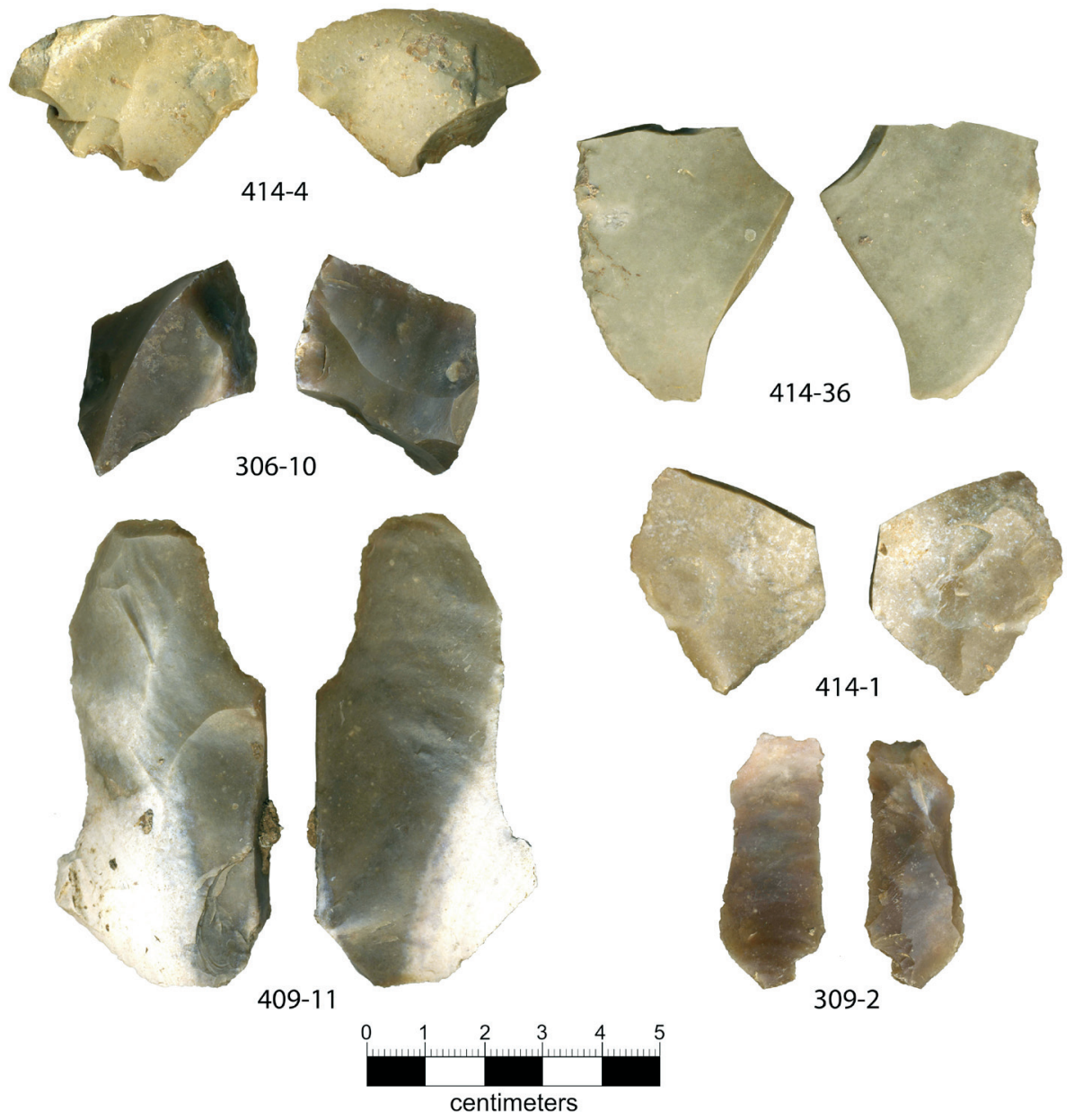

Figure 7-23. Flake tools from excavation units 3 and 4. 

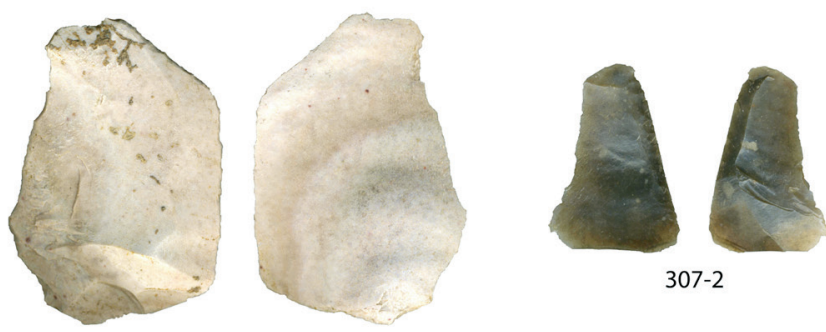

$307-2$

$429-1$

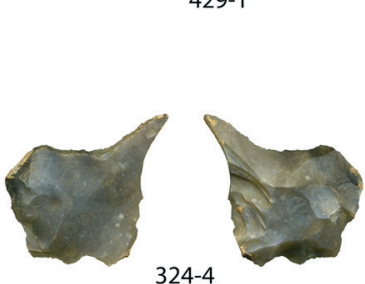

$324-4$
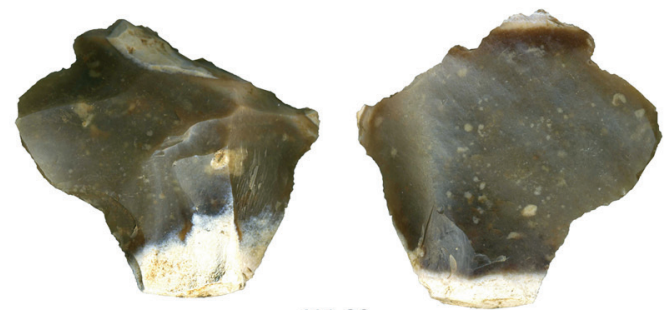

$411-28$

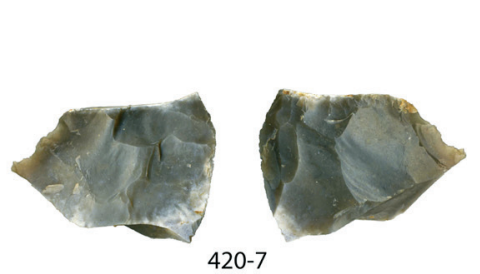

$420-7$

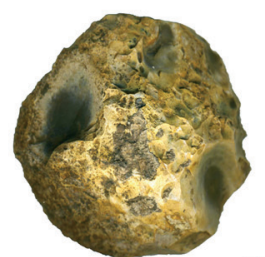

$411-27$

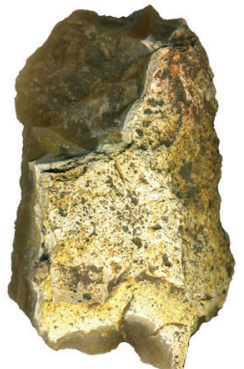

$308-43$
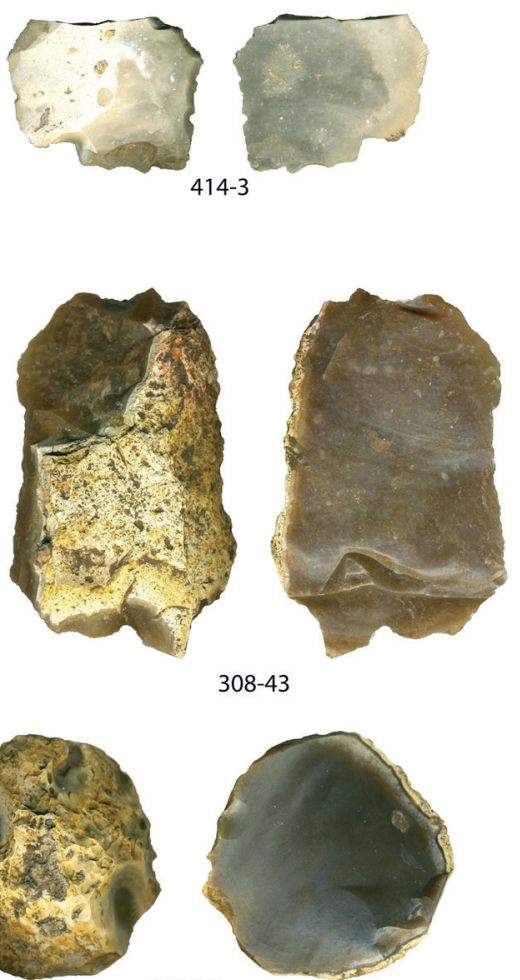

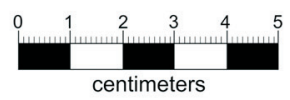

Figure 7-24. MRUs from excavation units 3 and 4.

exhaustion. The flaking on specimen 412-22 alternates between removals from the core face and the platform, making it a discoidal bidirectional, or bifacial core.

\section{Multidirectional $(n=5)$}

Specimens 400-8 and 403-7 are multidirectional cores; both have flake removals from multiple directions originating from multiple platform surfaces (Figure 7-29 A, B). Specimen 326-5 is a fragment of a multidirectional core. Specimen 327-3 is an exhausted multidirectional core, and 418-2 is an ad hoc multidirectional core (Figure 7-29 C).

\section{Indeterminate $(n=1)$}

One specimen (308-7) could not be sorted into one of the above described categories due to its fragmentary state. This fragment has multiple surfaces shaped by flake scars, however without the distal ends of the flake scars present, it is not possible to determine the core type. 


\section{Chapter 7}

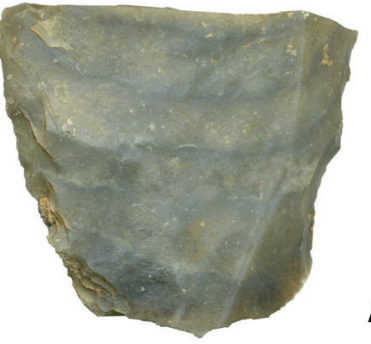

A

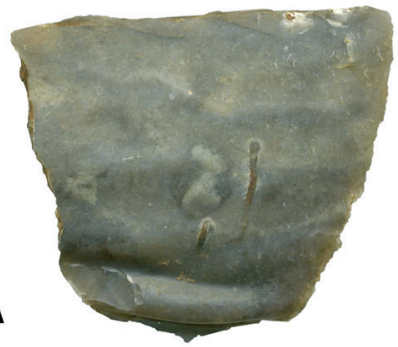

$314-28$

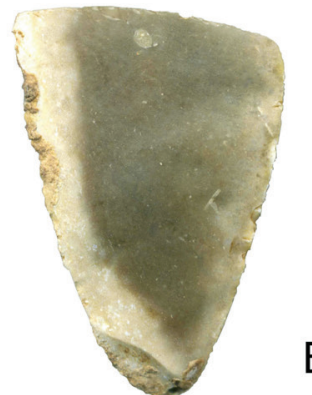

$312-32$

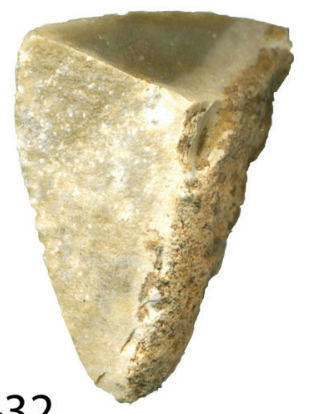

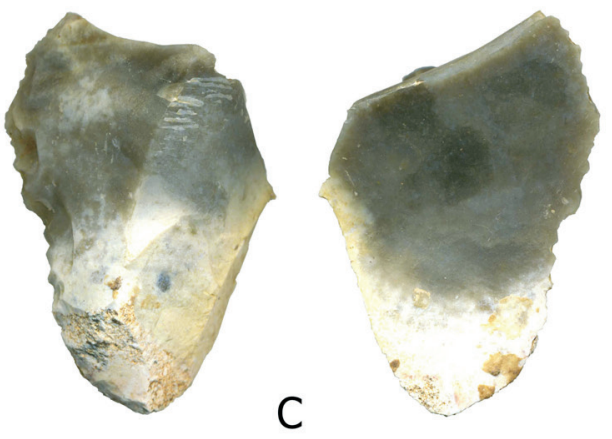

414-2

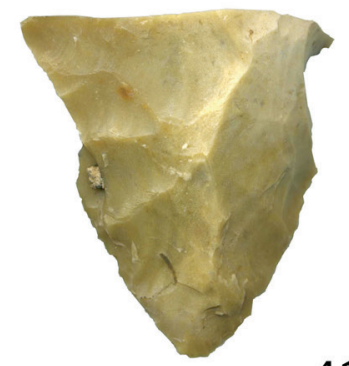

$412-9$

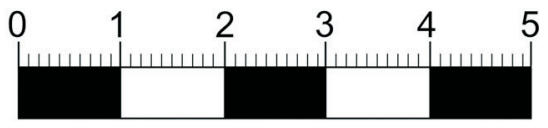

centimeters

Figure 7-25. Proximal fragments of edge modified pieces that possibly represent the haft element of scrapers that were broken during use.

\section{Debitage}

All unmodified pieces of chipped stone debris were placed into the general category of debitage. This category contained by far the largest number of individual artifacts of all lithic artifacts ( $\mathrm{n}=14,875$ from Units 3 and 4). Debitage includes flakes and flake fragments from deliberate removals that reflect the process of shaping or resharpening stone tools. This category also includes spalls or pieces that detached under extreme heat, and pieces of shatter that broke from larger flakes or stone masses during the process of hard hammer percussion. Given the small excavation sample, no detailed analysis was conducted of the debitage recovered from Units 3 and 4 . However, overall rates of recovery are very useful in providing a general indication of activity or site occupation intensity, and can help to define depositional units that reflect the natural and cultural stratigraphy in this part of the Spring Lake site. 


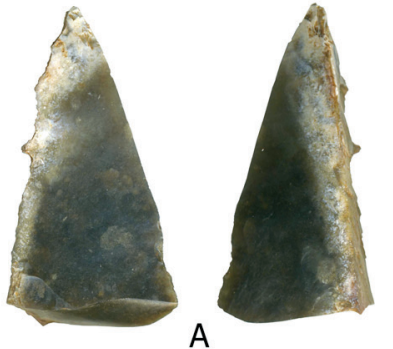

415-5

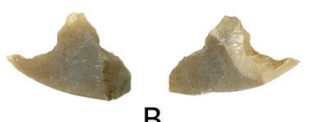

$413-20$

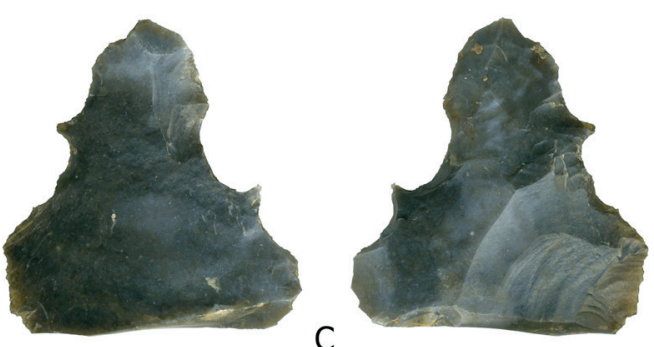

$304-10$

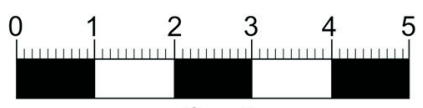

centimeters

Figure 7-26. Other lithic tools: (A) Awl; (B) Graver fragment; (C) Multi-edge graver.

Quantifying debitage recovery is done using both counts and total recovered mass, presented in grams. Each measure by itself potentially skews the total understanding of lithic recovery, as both weight and count can be affected by increases or decreases in flake size, the degree of burning encountered in a given level, or other factors that affect these measures (see discussion of faunal recovery for related considerations). Using both together, however, presents a more accurate and complete understanding of stone tool reduction behavior over time. The result (Figure 7-30) shows distinct peaks in debitage frequency and mass, which, as expected, generally parallel one another. The main exception occurs in level 2 , which as discussed above includes compressed sediments.

Some peaks correspond with faunal recovery patterns while others do not. For example, debitage begins to increase in both frequency and mass together with faunal count and mass starting at $55 \mathrm{~cm}$ below datum (cmbd). However, the maximum occurrence of debitage is slightly below that of fauna, by $5-10 \mathrm{~cm}$. We suggest that this offset is probably real, and indicates that stone working at the site was most active (in terms of debitage by-products) prior to the maximum occurrence of faunal remains. Based on the calibrated radiocarbon age, debitage peaked in frequency just after 4140-3980 cal B.P., or close to the beginning of the Late Archaic, while faunal recovery peaked soon thereafter. The fact that the increase in debitage begins one or two excavation levels before the increase in faunal recovery suggests that the sharp uptick in stone working was not, at least initially, related to animal hunting or processing of animal remains.

Also notable are the patterns in debitage occurrence just before, during, and just after the Calf Creek component at around $155 \mathrm{cmbd}$. The sharp increase in fauna count and mass from $155-165 \mathrm{cmbd}$ is related to the presence of bison in the faunal assemblage. However, debitage notably decreases at this depth. Perhaps the only conclusion that can be supported by this limited sample is that stone working, at least as relates to point production or associated with 


\section{Chapter 7}
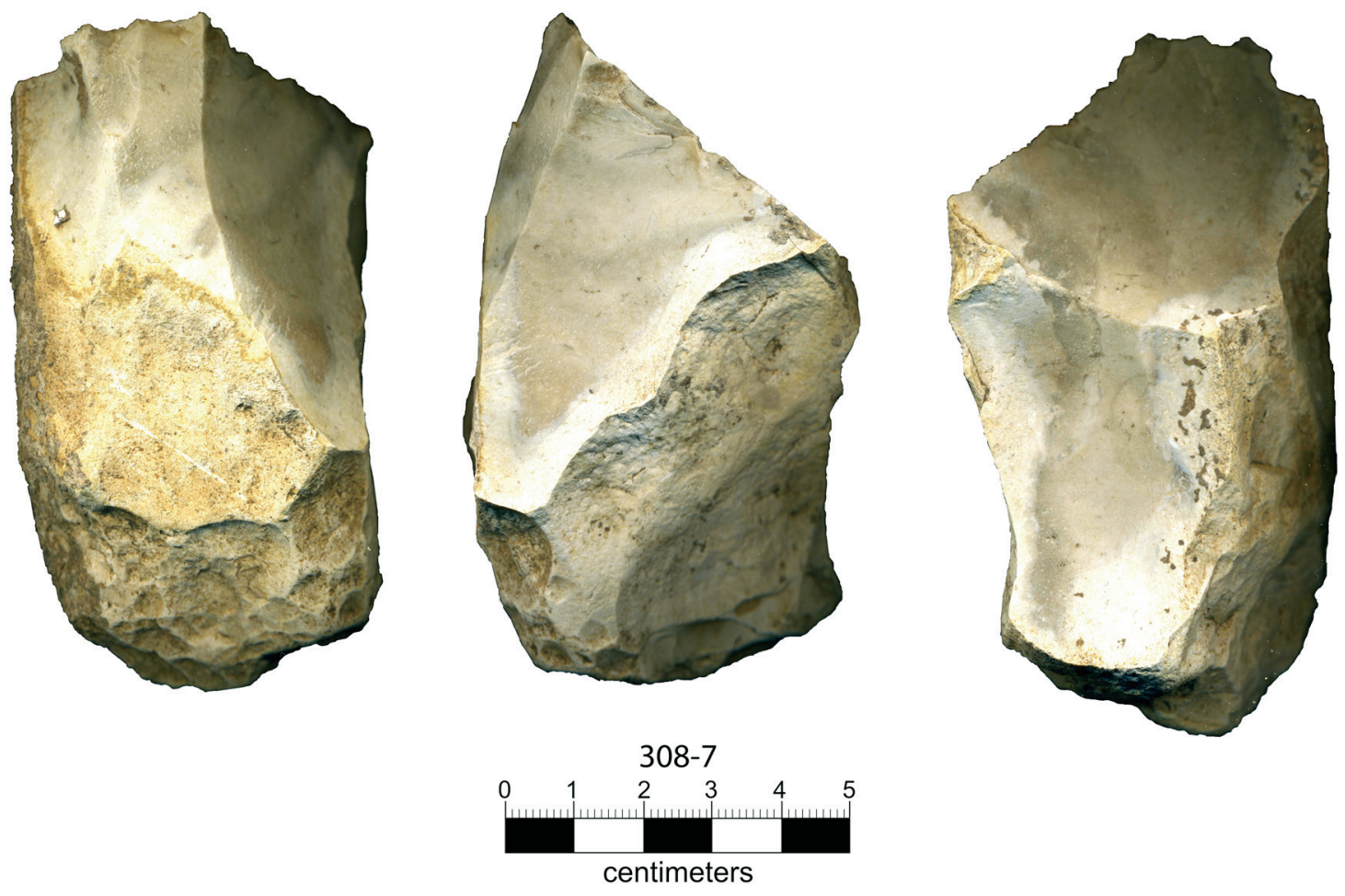

Figure 7-27. Unidirectional core.

processing a suite of subsistence resources that included bison, was not a major activity in this part of the site. However, a larger sample is necessary before this conclusion can be accepted with total confidence.

Starting just below $175 \mathrm{cmbd}$, debitage begins to decline in count and mass, following the trend recorded for faunal material. As noted previously, this is believed to be the result of higher rates of sedimentation at this locale prior to ca. $6000 \mathrm{cal}$ B.P.

\section{Fire-Cracked Rock}

Fire-cracked rock (FCR) was recovered from excavation levels in Units 3 and 4 and counted and weighed in order to calculate the frequency of occurrence of this artifact category. Like debitage, FCR counts alone are not entirely meaningful. Limestone rocks were used in prehistoric times because of their heat retention properties (Thoms 2009), and as they heated and cooled over multiple events, they tended to fracture into smaller and smaller pieces. Once fragments became too small for use, they were discarded and replaced with fresh cobbles. As a result, FCR counts may reveal less about the importance of hot rock cooking than FCR mass. Mass, however, can be skewed in smaller samples like this one by the presence of a small number of above-average size rocks. Changes in FCR count vs. weight indicates the degree to 

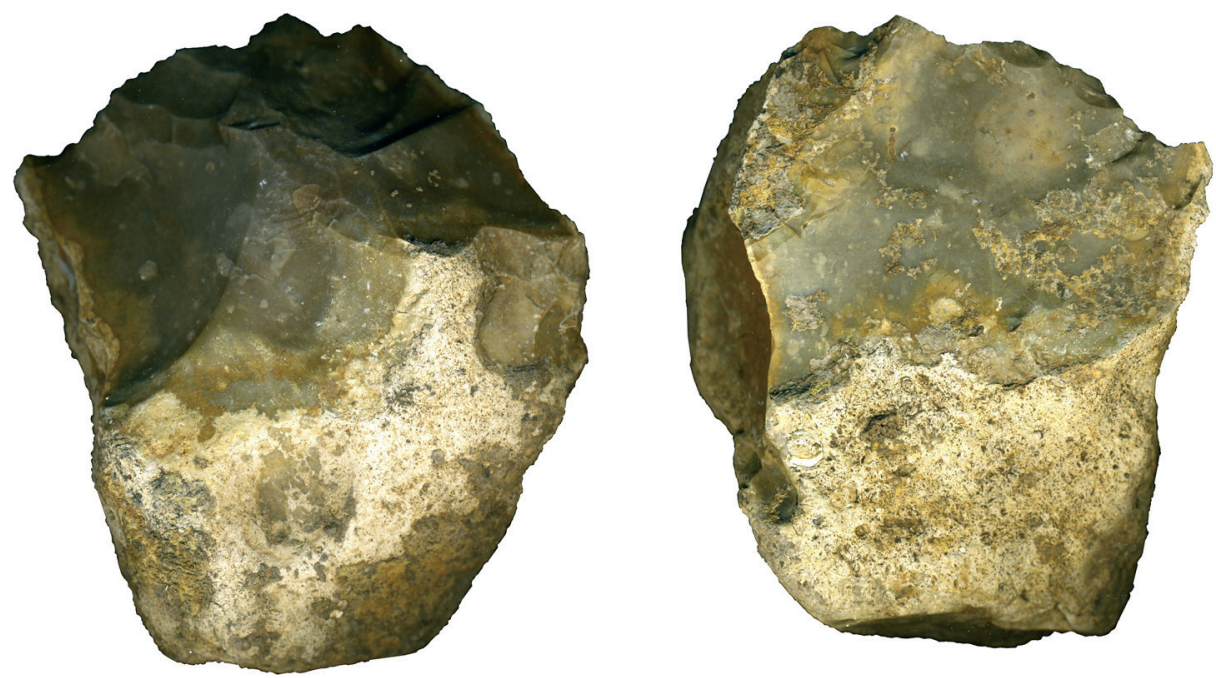

A

403-47

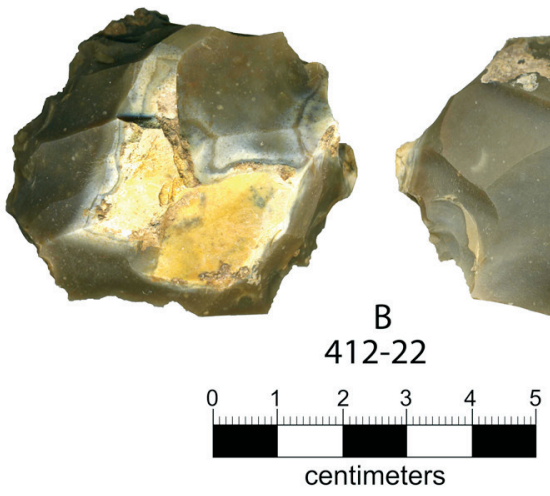

Figure 7-28. Bidirectional cores.

which limestone cobbles may have been reused and recycled in earth oven features. Increases in count that are not closely reflected in mass suggest that cobbles were reused extensively. Given a suitably large sample, such data may provide evidence for resource intensification, population pressures on the subsistence base, or some other factor. Both mass and count are plotted in order to provide a more complete view of earth oven technology and its importance at this part of the Spring Lake site over time (Figure 7-31).

The FCR data typically follow the same general trends seen in fauna and debitage. The largest peak in FCR occurrence occurs at $105 \mathrm{cmbd}$, just after $4140-3980 \mathrm{cal}$ B.P. It is interesting that FCR mass peaks sharply and then declines gradually throughout the remainder of the deposit. This suggests that the period of maximum importance for earth oven technology did not span a very long period of time. Toward the top of the deposit, at $45 \mathrm{cmbd}$, 


\section{Chapter 7}
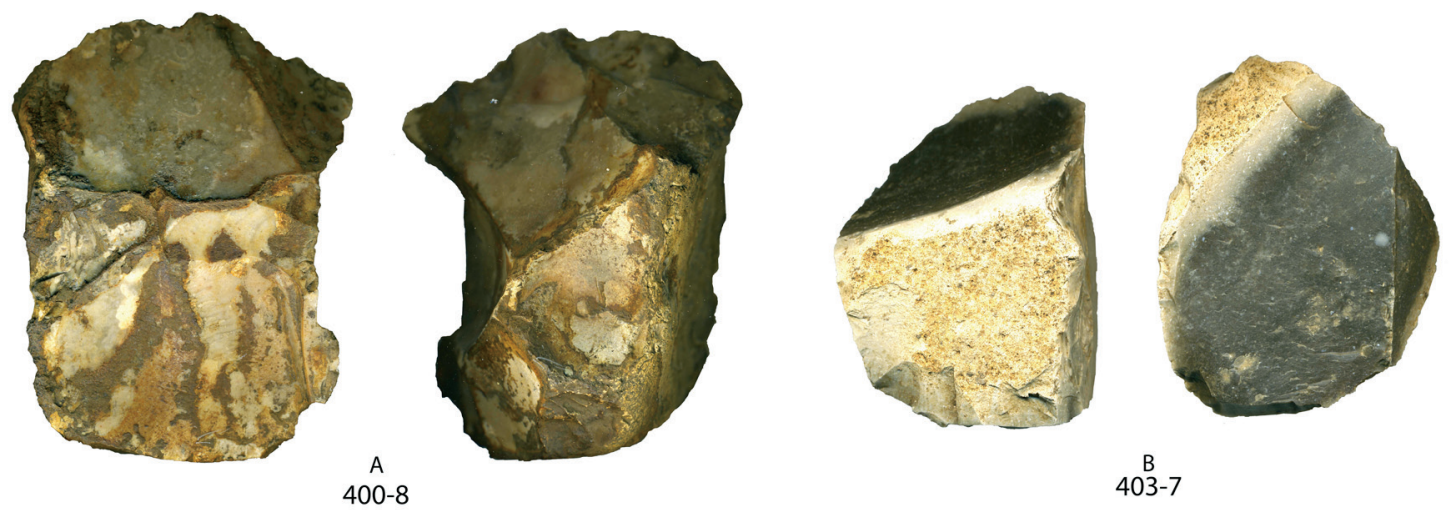

$400-8$

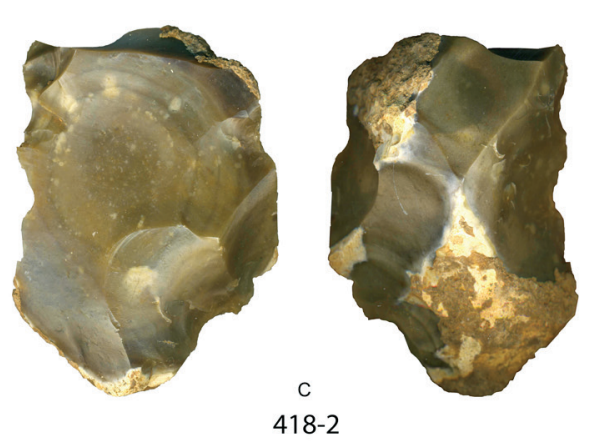

$\stackrel{B}{B}-7$

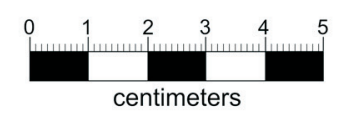

Figure 7-29. Examples of multidirectional flake cores.

the small peak in FCR counts is only very slightly mirrored in FCR mass, suggesting that cobbles were recycled more intensively during this period. Because the upper portions of this deposit seem to be compressed, it may not be possible to identify clearly what time period is represented by this late intensification of heated rocks. However, it is likely to date to or just after Late Prehistoric Toyah times based on the date of 544-514 cal B.P. at $75 \mathrm{cmbd}$.

Lower in the deposit, below $105 \mathrm{cmbd}$, counts fluctuate sharply while mass peaks slightly at $135 \mathrm{cmbd}$ (following a sharp decline from the maximum at $105 \mathrm{cmbd}$ ) before declining again down profile. A modest increase in both counts and mass present at $175 \mathrm{cmbd}$ dates to between 6182-6142 and 5982-5767 cal B.P. Taken together, FCR data at and just above this elevation range may be used to characterize Calf Creek subsistence as less dependent on earth oven cooking than in immediately preceding and following periods. This seems clearly demonstrated by FCR mass. Variation in FCR counts can be understood as differing degrees to which heated stones were reused in oven features. 


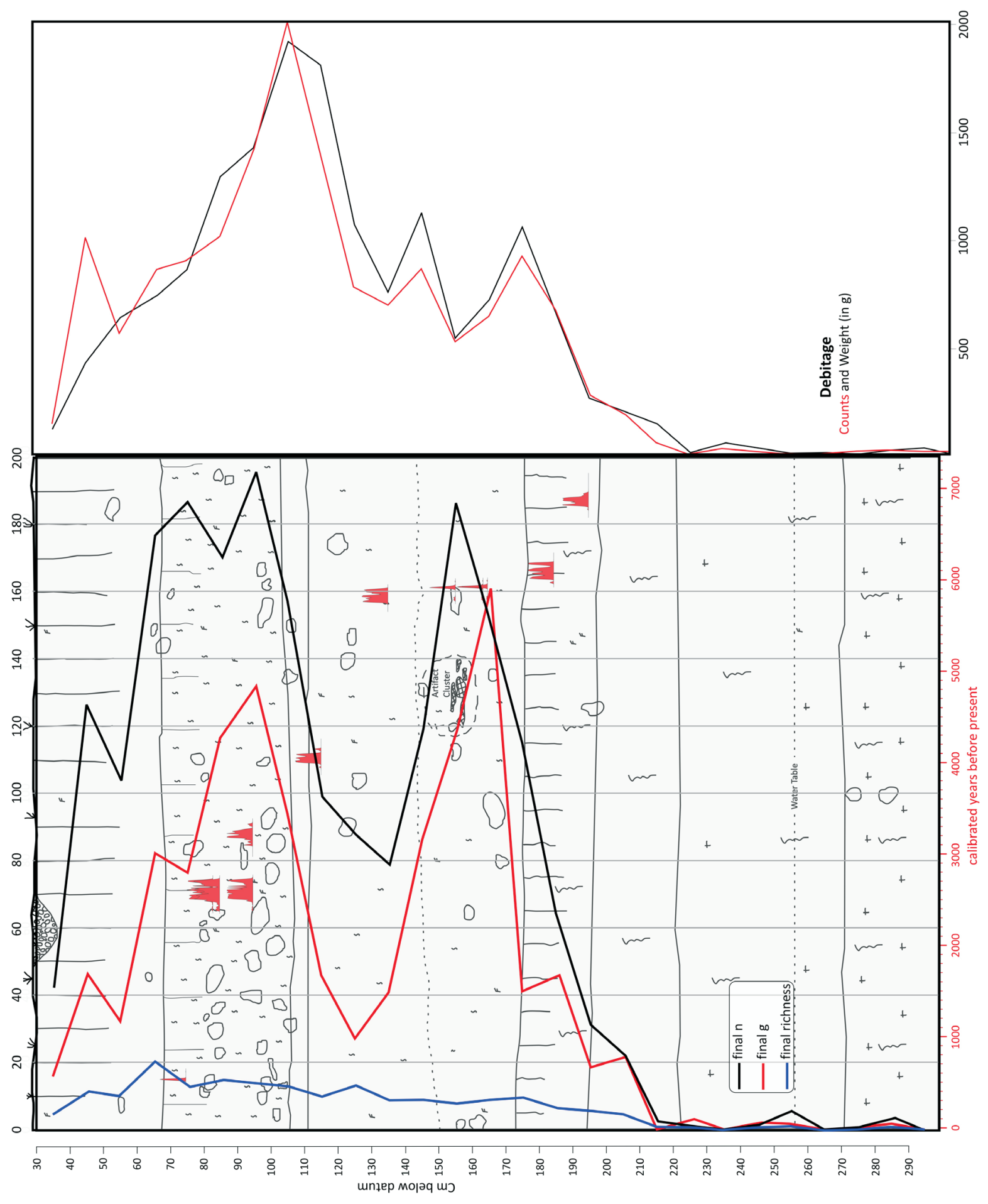

Figure 7-30. Recovery of debitage (counts in red, mass in black) compared with faunal recovery by depth. 


\section{Chapter 7}

Below $175 \mathrm{cmbd}$, FCR counts and mass both decline to almost zero until around $295 \mathrm{cmbd}$. Again, this provides evidence for accelerated sedimentation rates prior to c. 6000 ca. B.P. It is interesting that the minor increase in FCR at the lowest depths of this excavation corresponds with minor increases in both fauna and debitage, suggesting that a small component is present that is associated with the drill made from a Gower point base that was recovered here.

\section{Modified Bone}

Three pieces of what appear to be modified bone were identified among the faunal assemblage from this excavation (Figure 7-32). Specimen 303-20 is a bone splinter from a small mammal (Figure 7-32 A). It has evidence of being cut on one end and has been polished along its length. This specimen is likely a fragment of a bone splinter tool (Wheeler and McGee 1994). Specimen 312-9 is a bone tool made from a limb diaphysis fragment of a medium-sized mammal (Figure 7-32 B). It consists of two fragments that refit together. One end has been modified into a smooth round surface; the other end has two smoothed surfaces that form a chisel shaped beveled tip. Beveled bone tools are often classified as awls. However, specimens similar to 312-9 have been connected with digging, prying, fleshing, shaping, burnishing, wood working, and bark stripping (Byrd 2011: 78, Griffitts 2006:187, Penders 1997;136, 158). Specimen 402-6 consists of two pieces that mend together to form a tubular bead (Figure 7-32 C). It measures $19.72 \mathrm{~mm}$ in length and $5.20 \mathrm{~mm}$ in thickness.

\section{Shell BeAD}

Specimen 314-1 is a tubular bead manufactured from the columella (core) of a marine gastropod species, Busycon perversum (lightning whelk) (Figure 7-33). This artifact was recovered from Level 15 of Unit 13, within the Calf Creek component. It measures $30.36 \mathrm{~mm}$ in length and $8.91 \mathrm{~mm}$ in thickness. Busycon perversum is a relatively large marine gastropod species; therefore beads like this one are commonly referred to as conch columella beads although the true conch is rarely found along the Texas coast (Dreiss 2009). Columella beads are cylindrical in shape, unlike discoidal beads which are made from the outer whorls of marine gastropods.

Data from archaeological sites located west of the Gulf of Mexico show that prehistoric marine shell distribution reached well beyond East Texas (Black 1986; Collins 1998; Hester 1971, 1980; Highley 1986). The occurrence of marine shell at inland sites in Texas is primarily documented during later periods in a variety of contexts and has led researchers to believe marine shells were desirable trade items (Shaw 1998; Dreiss 2009). One of the few examples of marine shell occurring in earlier contexts comes from investigations at the Wilson-Leonard site, where small marine gastropod shell beads were recovered from Late Paleoindian and Early Archaic contexts (Shaw 1998). Whereas marine shell has been recovered from many inland sites, columella beads are uncommon. When they do occur at inland sites, they are mostly found in Late Archaic, Late Prehistoric and Historic mortuary contexts (Dreiss 1994). 


\section{Ceramics}

This section describes the small sample $(n=5)$ of ceramic artifacts collected from the present project. Descriptions focus on macroscopic attributes such as surface characteristics and temper use. Following the methodology used by Tomka et al. (2013), surface treatments (interior and exterior) of the sherds were recorded as rough, smooth, polished, floated, rough,
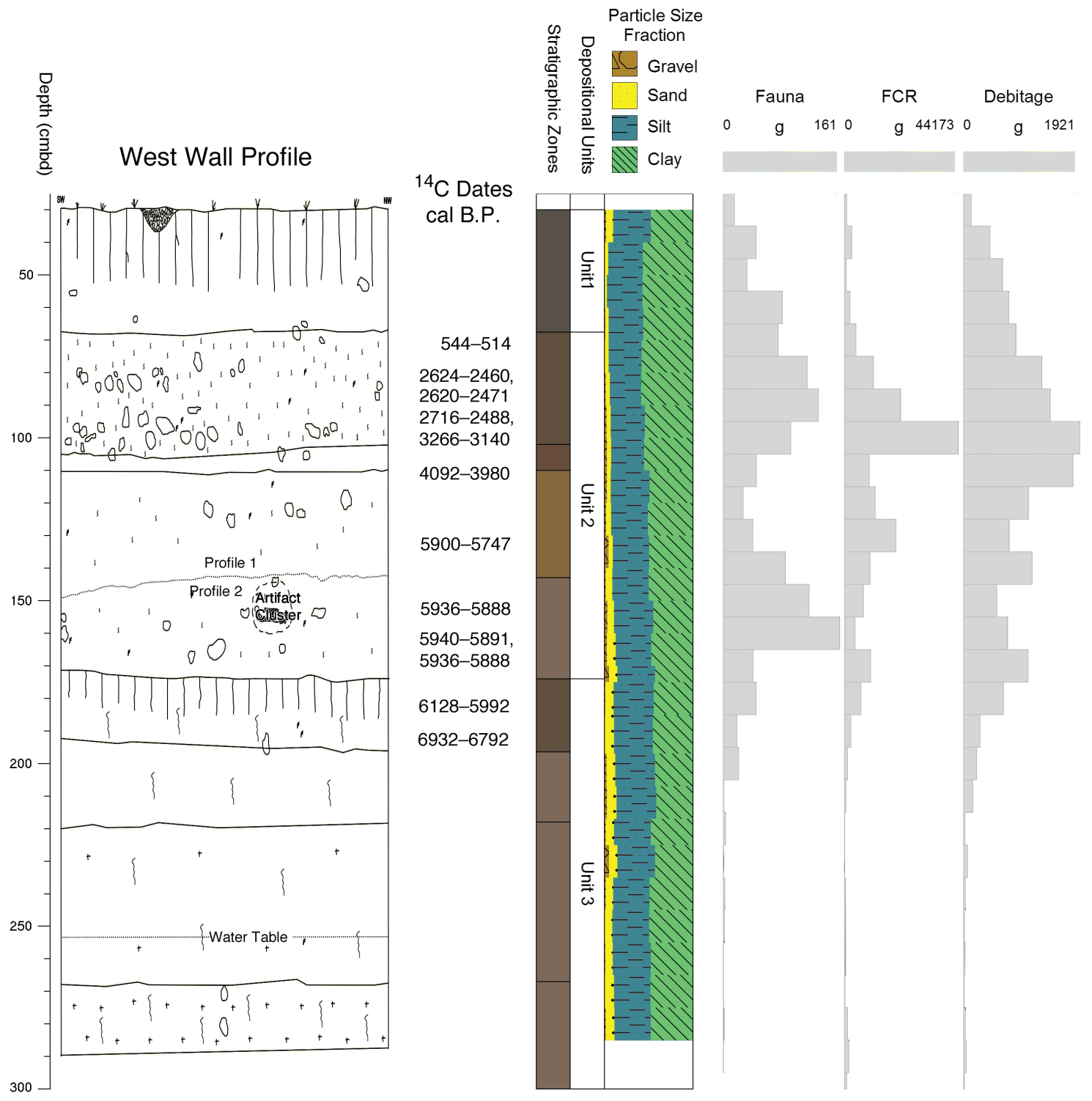

Figure 7-31. Recovery data for FCR compared with fauna and debitage. 


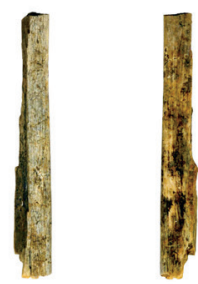

A

$303-20$
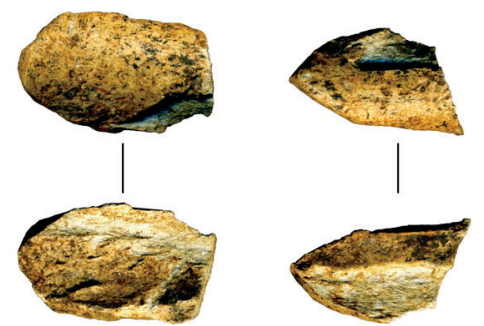

B

$312-9$

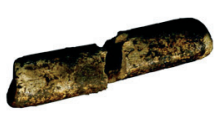

C

402-6

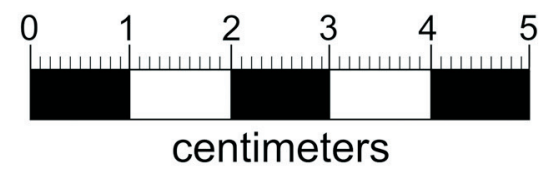

Figure 7-32. Bone tools fragments and bead from Units 3 and 4.
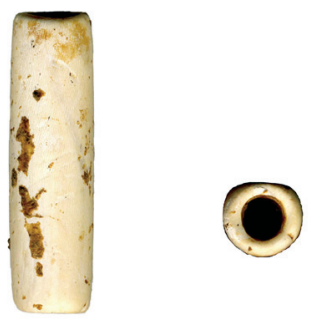

314-1

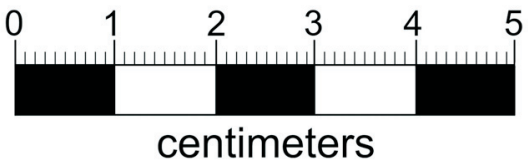

Figure 7-33. Marine columella bead.

slipped, or brushed. Rough surfaces are characteristic of poor smoothing or no smoothing at all. A smooth surface is smooth to the touch, but lacks evidence of polishing that produced sheen. Polished surfaces exhibit a slight to high gloss. Floated surfaces have a thin polished layer that masks most of the temper particles. Slipped surfaces have sheen similar to floated surfaces, but also exhibit a distinct difference between the sherd paste and the color of the surface. A brushed surface exhibits striations.

The sherds were also examined for decoration (applied substance, incising etc). Wall thickness was measured in millimeters with digital calipers (Table 7-5). All fragments were recorded as base, body or rim fragments. Orifice diameter (vessel opening) of rim fragments 
was determined by placing the rim fragment on a concentric circle chart. Considering the small size of these sherds, however, this determination is considered an approximation at best. The paste color was determined with a Munsell soil color chart for the interior, exterior and core of the sherds. The firing atmospheres were recorded according to the color that the sherds exhibited. For example, black to light grey indicates a reduced atmosphere while buff to red colors indicate an oxidizing atmosphere (Tomka et al. 2013).

Table 7-5. Metric and Observed Data for Ceramic Fragments

\begin{tabular}{|c|c|c|c|c|c|}
\hline Specimen No. & $53-11$ & $58-1$ & 101-1 & $302-4$ & $400-5$ \\
\hline Provenience & $\begin{array}{l}\text { Monitor- } \\
\text { ing: Electric } \\
\text { Line Trench }\end{array}$ & $\begin{array}{l}\text { Burial Test- } \\
\text { ing }\end{array}$ & $\begin{array}{l}\text { Unit } 1 \\
\text { Level } 2\end{array}$ & $\begin{array}{l}\text { Unit } 3 \\
\text { Level } 3\end{array}$ & $\begin{array}{l}\text { Unit } 4 \\
\text { Level } 1\end{array}$ \\
\hline $\begin{array}{l}\text { Surface Treatment, } \\
\text { Interior }\end{array}$ & Floated & Floated & Brushed & Smoothed & Smoothed \\
\hline $\begin{array}{l}\text { Surface Treatment, } \\
\text { Exterior }\end{array}$ & Floated & Floated & Brushed & Smoothed & Polished \\
\hline $\begin{array}{l}\text { Paste Morphology, } \\
\text { Inclusion }\end{array}$ & Sand & Sand & Shell & Bone & Bone \\
\hline $\begin{array}{l}\text { Paste Morphology, } \\
\text { Inclusion Size }\end{array}$ & Small & Small & $\begin{array}{l}\text { Small- } \\
\text { Moderate }\end{array}$ & Moderate & Moderate \\
\hline $\begin{array}{l}\text { Paste Morphology, } \\
\text { Texture }\end{array}$ & Fine & Fine & Fine & Fine & Fine \\
\hline Wall Thickness (mm) & 6.56 & 7.27 & 7.74 & 6.86 & 6.64 \\
\hline Vessel Fragment & Body & Body & Body & Body & Rim \\
\hline Interior Paste Color & $7.5 \mathrm{YR} 5 / 6$ & $7.5 \mathrm{YR} 5 / 6$ & 10YR6/2 & 10YR4/2 & $2.5 \mathrm{Y} 2.5 / 1$ \\
\hline Exterior Paste Color & 7.5YR3/1 & $\begin{array}{l}10 Y R 3 / 2 \\
10 Y R 5 / 3\end{array}$ & 7.5YR6/3 & 10YR4/1 & $2.5 \mathrm{Y} 3 / 1$ \\
\hline Interior Firing & Oxidized & Oxidized & Reduced & Reduced & Reduced \\
\hline Exterior Firing & Reduced & Reduced & Oxidized & Reduced & Reduced \\
\hline
\end{tabular}

Following guidelines provided by the Council of Texas Archaeologists (CTA), fresh breaks were made on the sherds in order to examine paste morphology (Ellis et al. 2010). The fresh breaks were examined closely with a $\times 10$ lens. Inclusions within the pastes were examined closely in order to identify the material used to temper the clay (bone, grog, sand, shell, etc.). The size of the inclusions was determined to be small, moderate or large. The texture of the paste was noted as either coarse or fine. 


\section{Chapter 7}

All five specimens are unglazed and undecorated (Figure 7-34). Specimens 53-11 and 58-1 have very fine sandy pastes that almost look "temperless." Both exhibit orange-red interiors and have dark brown exteriors. Specimen 101-1 has shell inclusions and brushed interior and exterior surfaces. Specimens 302-4 and 400-5 exhibit bone tempered pastes. Specimen 400-5 is a small rim fragment from an indeterminate vessel form. It exhibits an outflaring rim with a rounded lip.
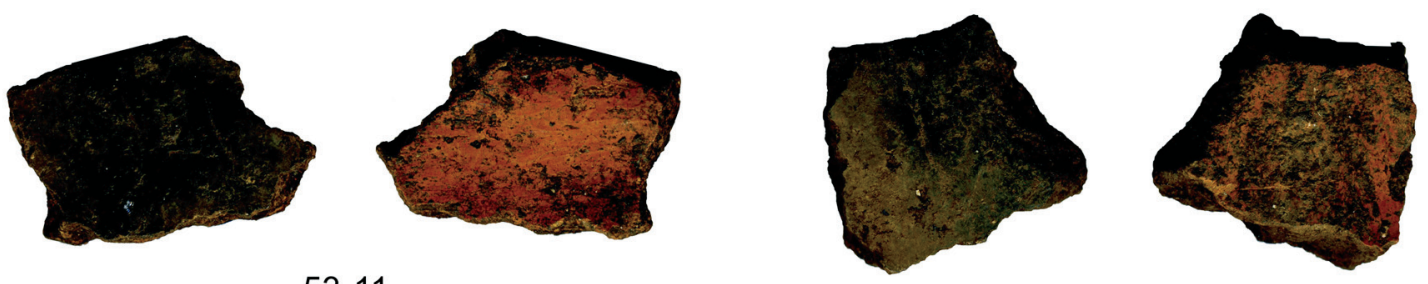

$53-11$

$58-1$
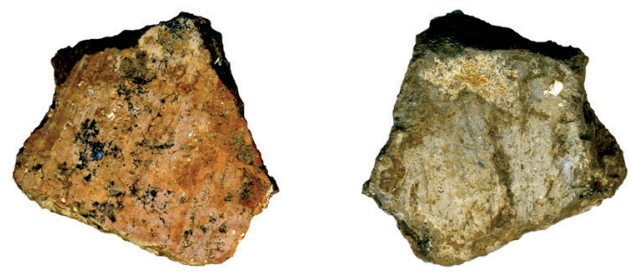

$101-1$
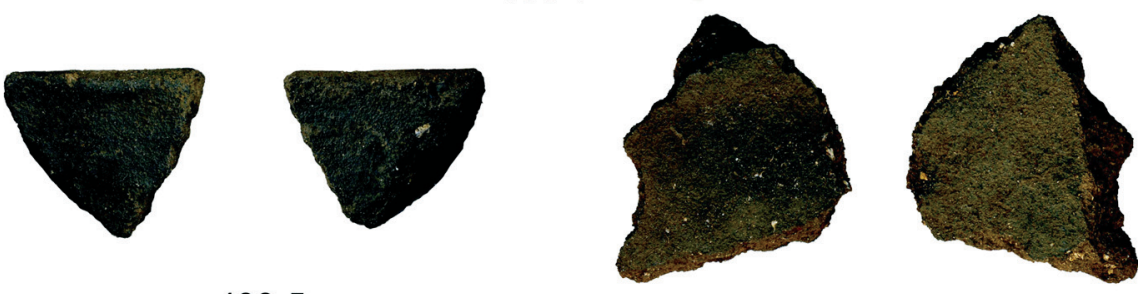

$400-5$

302-4

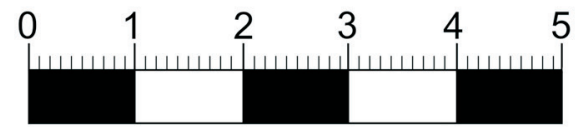

centimeters

Figure 7-34. Ceramic fragments from the Ticket Kiosk excavations. 


\section{Chapter 8 Results of Monitoring Activities}

by Amy E. Reid and David M. Yelacic

Throughout the year during and following the controlled excavation of Units 3 and 4, CAS monitored several construction-related excavations associated with the new ticket kiosk and restroom facility (see Figure 3-4). Activities that required archaeological monitoring are organized into eight events and are summarized below. This chapter presents the findings of these monitoring events, the most notable of which was the recovery of a prehistoric burial located along an electric utility trench. Summaries of the burial excavation and bioarchaeological analyses are also presented.

\section{Sidewall Benching Monitoring}

On June 29, 2011, Units 3 and 4 reached a depth of $1.2 \mathrm{~m}$ below the ground surface. In order to comply with excavation trench safety protocols, a section of earth extending $2 \mathrm{ft}$ in all directions around the hand-excavated units was mechanically stripped in order to prevent the sidewalls from caving in (Figure 8-1). In addition to the careful monitoring of this excavation, earth that was removed during this process was piled near the unit for later examination. Four bifaces and two projectile points were recovered during careful monitoring. One projectile point was identified as a Pedernales; the other was typed as a Travis (see Figure 7-6: 432-2 and Figure 7-8: 432-1). Once the sidewall benching was complete, the excavated sediment was examined on various occasions throughout the rest of the project as time permitted. This process resulted in a number of additional artifacts being collected, including one untypable projectile point fragment (see Figure 7-15: 431-2), one Scallorn arrow point (see Figure 7-12 B) and six bifaces (Appendix C).

\section{Auger Monitoring}

Thirty-nine augers were excavated on June 30, 2011, for the building foundation support. These auger excavations were located east of the field school data recovery excavations 


\section{Chapter 8}

(2001, 2002, 2003 and 2006 seasons) and west of the lift station excavation units (Figure 8-2). Cultural material was encountered in 38 of the auger holes (Table 8-1). Two bifaces, one projectile point and one piece of bison bone were collected; all other observed material was counted and described and then discarded. The projectile point, recovered from Auger No. 10, was identified as a Castroville (see Figure 7-10: 7-2). Overall, these auger excavations confirmed that prehistoric archaeological deposits associated with 41HY160 are present in this area, and the recovered Castroville point complements previously recorded in situ projectile points indicating Late Archaic period occupation of the site.

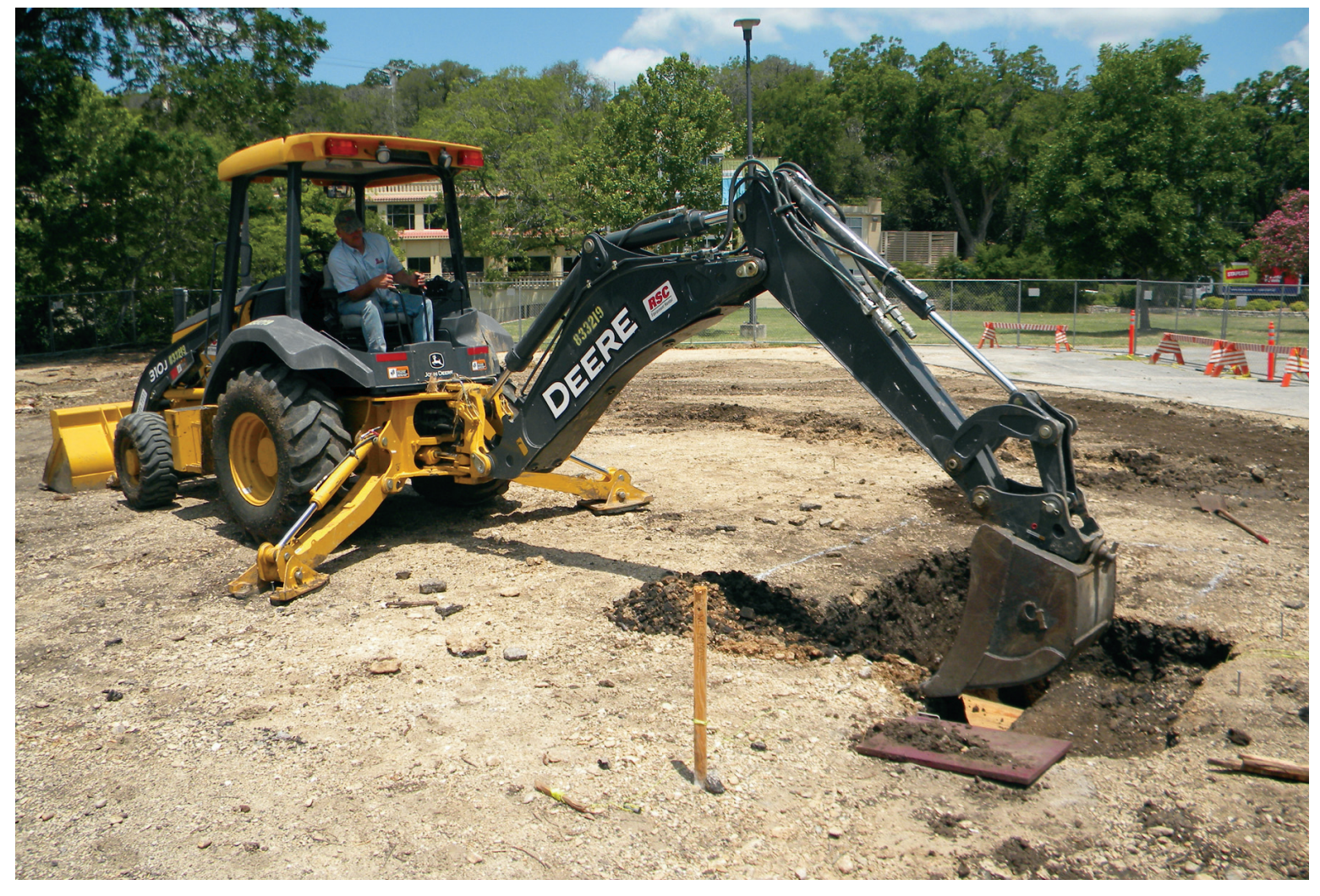

Figure 8-1. Mechanical stripping of an area around Units 3 and 4 in order to trench unit walls for safety. The bottom of excavation units were covered with plywood, visible in photo beneath backhoe buket, in order to protect unexcavated sediments. 
Table 8-1. Cultural Material from Auger Excavations.

\begin{tabular}{|c|c|}
\hline Auger Number & Cultural Material (count) \\
\hline 1 & Sterile \\
\hline 2 & Debitage (1), round nail (1) \\
\hline 3 & Debitage (1), FCR (3) \\
\hline 4 & FCR $(2)$ \\
\hline 5 & Debitage (1), FCR (2) \\
\hline 6 & Debitage (1), FCR (> 10) \\
\hline 7 & FCR (3) \\
\hline 8 & FCR (1) \\
\hline 9 & Debitage (1), FCR (2), bone (1), charcoal \\
\hline 10 & FCR $(>10)$, projectile point*, bison bone* \\
\hline 11 & FCR $(>10)$ \\
\hline 12 & Debitage (1), FCR (5-10) \\
\hline 13 & $\mathrm{FCR}(2)$ \\
\hline 14 & FCR (4) \\
\hline 15 & FCR (5) \\
\hline 16 & Debitage (1), FCR (5-10) \\
\hline 17 & FCR $(1)$ \\
\hline 18 & Debitage (1), FCR (> 10) \\
\hline 19 & Debitage (2), FCR (5-10), faunal bone (1) \\
\hline 20 & Debitage (2), FCR (> 10) \\
\hline 21 & Debitage (7), FCR (5-10), faunal bone (7) \\
\hline 22 & FCR (2) \\
\hline 23 & FCR $(5-10)$ \\
\hline 24 & Debitage (2), FCR (5-10) \\
\hline 25 & Debitage (1), FCR (5-10), biface* (1) \\
\hline 26 & Debitage (3), FCR (1), faunal bone (1) \\
\hline 27 & Biface* $^{*}(1)$, FCR (> 10), faunal bone (2) \\
\hline 28 & Debitage (1), FCR (5-10) \\
\hline 29 & Debitage (1), FCR (5-10), faunal bone (1) \\
\hline 30 & Debitage (1), FCR (5) \\
\hline 31 & FCR (5-10), faunal bone (1) \\
\hline 32 & FCR (5), faunal bone (1) \\
\hline 33 & Debitage (1), FCR (5-10) \\
\hline 34 & Debitage (1), FCR (5) \\
\hline 35 & Debitage (1), FCR (5) \\
\hline 36 & Debitage (2), FCR (5-10) \\
\hline 37 & Debitage (1), FCR (1) \\
\hline 38 & FCR (3) \\
\hline 39 & FCR (5) \\
\hline \multicolumn{2}{|l|}{ * indicates collectec } \\
\hline
\end{tabular}




\section{Chapter 8}

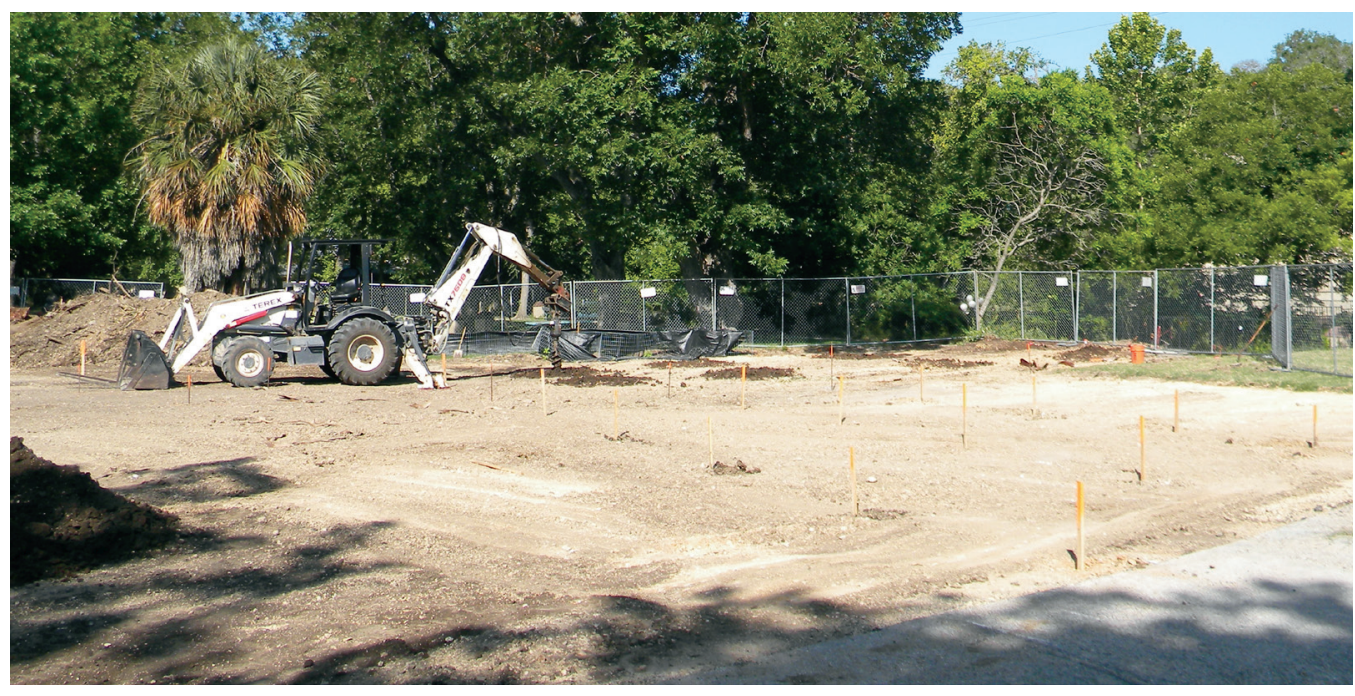

Figure 8-2. Auger excavations, facing southwest with stakes marking auger locations.

\section{Plumbing Trenches}

On August 12, 2011, CAS archaeologists monitored the opening of six trenches excavated for the installation of plumbing utilities in the north building (Figure 8-3). Construction fill was encountered in all trenches at approximately 0-30 cmbs. The maximum absolute depth excavated was $90 \mathrm{cmbs}$. Debitage and faunal bone was encountered in all trenches below the construction fill. Three bifaces (Appendix C) and one distal fragment of a formal uniface were recovered while monitoring the plumbing excavations (Figure 8-4). A Nolan projectile point was recovered from the excavated sediment of the trench just west of excavation Unit 4. Based on the depth of this trench, this point is probably not in a primary Middle Archaic deposit, but

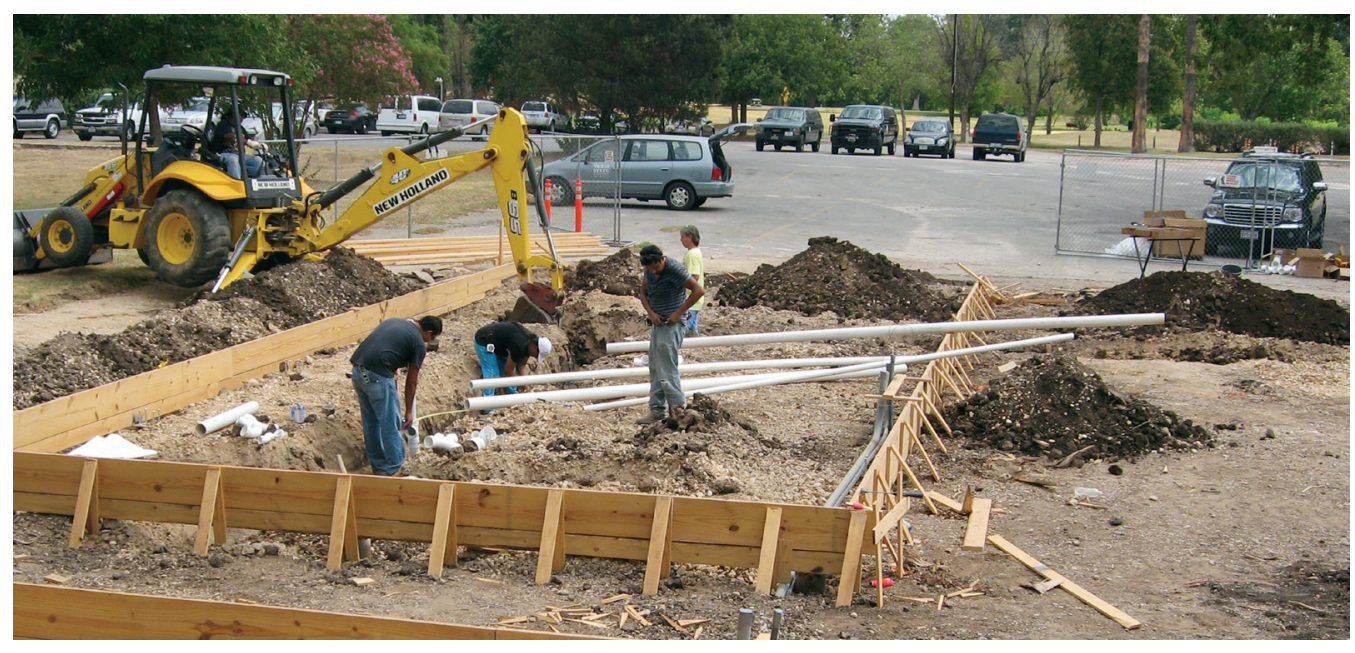

Figure 8-3. Overview of north building plumbing project, facing north. 

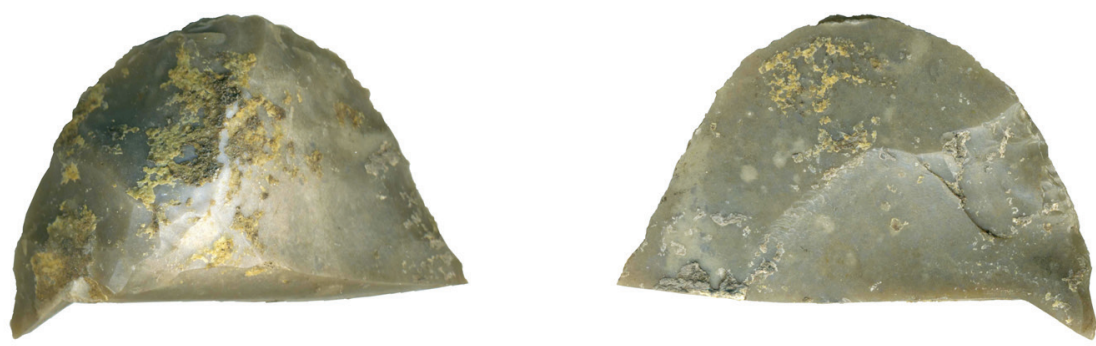

$56-4$

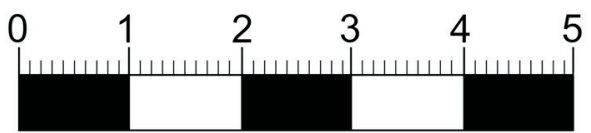

centimeters

Figure 8-4. Formal uniface fragment recovered during monitoring of trenches for plumbing utilities.

rather was reused and recycled by later occupants at this locale. Nevertheless, this artifact helps confirm the understanding of this area as a rich deposit spanning Middle to Late Archaic periods (see Figure 7-5: 56-3).

\section{Electric Line Trench}

On September 8, 2011, CAS archaeologist David Yelacic monitored the excavation of a trench that measured approximately $1 \mathrm{ft}(30 \mathrm{~cm})$ wide and $2 \mathrm{ft}(60 \mathrm{~cm})$ deep. This trench was excavated from the southeast edge of the north building to an existing electric line underneath the paved street that separates the construction site from the TxSt Golf Course (see Figure 3-4 for trench location). Lithic debitage, faunal bone, charcoal, burned clay and burned rock were observed while monitoring this trench. Collected artifacts include two cores, one biface (Appendix C), one ceramic fragment (See Figure 7-34 53-11), and four projectile points; all recovered from 0-45 cmbs. The four points were identified as Gower, Nolan, Castroville and Fairland (see Figure 7-2 D, Figure 7-5: 53-2, Figure 7-10: 53-1 and Figure 7-11 E). In addition, four large stones were exposed approximately $7 \mathrm{~m}$ to the southeast of the foundation and at a depth of 50-60 cm below the surface. When the excavation was stopped so that the stones could be examined, a human cranium was discovered (Figure 8-5). Upon screening the associated sediment, CAS archaeologists recovered long bone fragments and phalanges. The large stones and remains were determined to be associated with a prehistoric cairn burial, and the electric line project was terminated. The exposed cranium was covered with burlap and soft sediment that had been pre-screened. The remains were then reburied to protect and preserve them until proper documentation could commence. This discovery and the process involved in the burial excavation are described later in this chapter. 
FIGURE REDACTED

Figure 8-5. CAS archaeologist David Yelacic investigating prehistoric burial. Oe of the large cairn stones is visible in the trench wall just above the excavation splint.

\section{Waterline Monitoring}

On January 18, 2012, CAS archaeologists monitored trenching for a waterline. The trench was excavated with a mechanical trencher from the previously mentioned paved road to the new building. Once complete, the trench measured 30-40 cm deep and 40-50 cm wide. A second trench, with similar dimensions, was excavated from the building to the lift station. The upper $35 \mathrm{~cm}$ of sediment in both trenches was found to be mixed with asphalt and construction base. A moderate amount of debitage was encountered within the excavated sediment below $35 \mathrm{~cm}$, and a large piece of charcoal was observed in the bottom of the first trench. No time-diagnostic material or cultural features were encountered, and no artifacts or other materials were collected.

Additional monitoring was necessary on February 7, 2012, during exploratory excavation to find an existing 2-inch waterline. The trench was excavated from the paved road northwest toward the lift station, the final dimensions of which measured $60-80 \mathrm{~cm}$ wide and $50-100 \mathrm{~cm}$ below surface. A large amount of lithic debitage and burned rock was encountered as well as two large faunal bone fragments, a polished bone fragment, a piece of possible ground stone, a large biface, two distal projectile point fragments and two large charcoal fragments. No timediagnostic artifacts were observed, and no artifact materials were collected. 


\section{Water Main Trench Monitoring}

On May 23, 2012, CAS archaeologists monitored the mechanical excavation of a relatively large area, where a municipal utility crew attempted to locate a water main in order to supply water to the new restroom facility. This excavation was located southwest of the restroom and ticket kiosk buildings and along the south side of the paved road. Intact sediments were encountered directly underneath the topsoil, and a significant amount of burned rock and lithic debitage was observed. A buried fence post with a cement base was identified in the southwest corner of the trench (Figure 8-6) indicating previously disturbed sediment in this limited part of the trench. After a couple of hours of excavations, the city crew was unable to locate the water main. Discussions ensued about how to increase the size of the trench until the waterline was located, including the possibility of extending the trench into the TxSt golf course. By this time, the U-shaped trench measured approximately $2 \mathrm{~m}$ wide, $7 \mathrm{~m}$ long, and was more than $1 \mathrm{~m}$ deep in some places (Figure 8-7). At this point, CAS archaeologists asked the city crew to stop their excavation and contacted TxSt personnel to discuss a less invasive process for locating the water main. The city crew agreed to stop, and CAS archaeologists continued to inspect the excavated sediment. Much more burned rock and lithic debitage as well as two bifaces were encountered. No time-diagnostic artifacts were observed. Ultimately, in consultation with TxSt

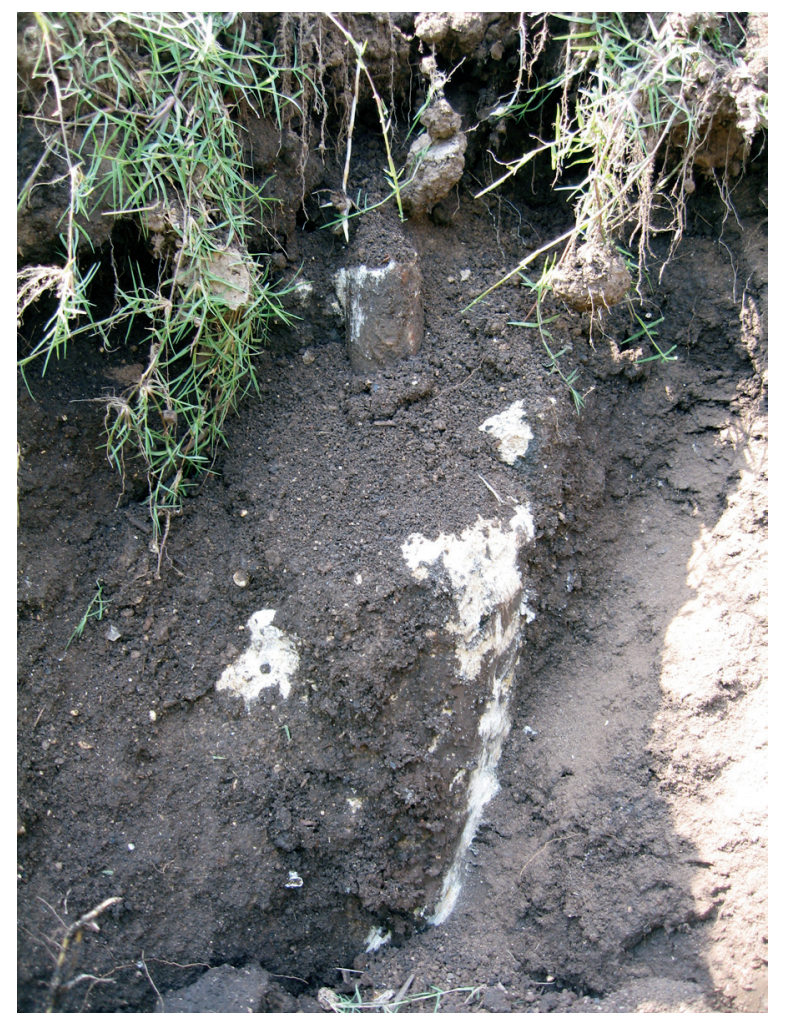

Figure 8-6. Closeup of a buried fence post with cement base. 


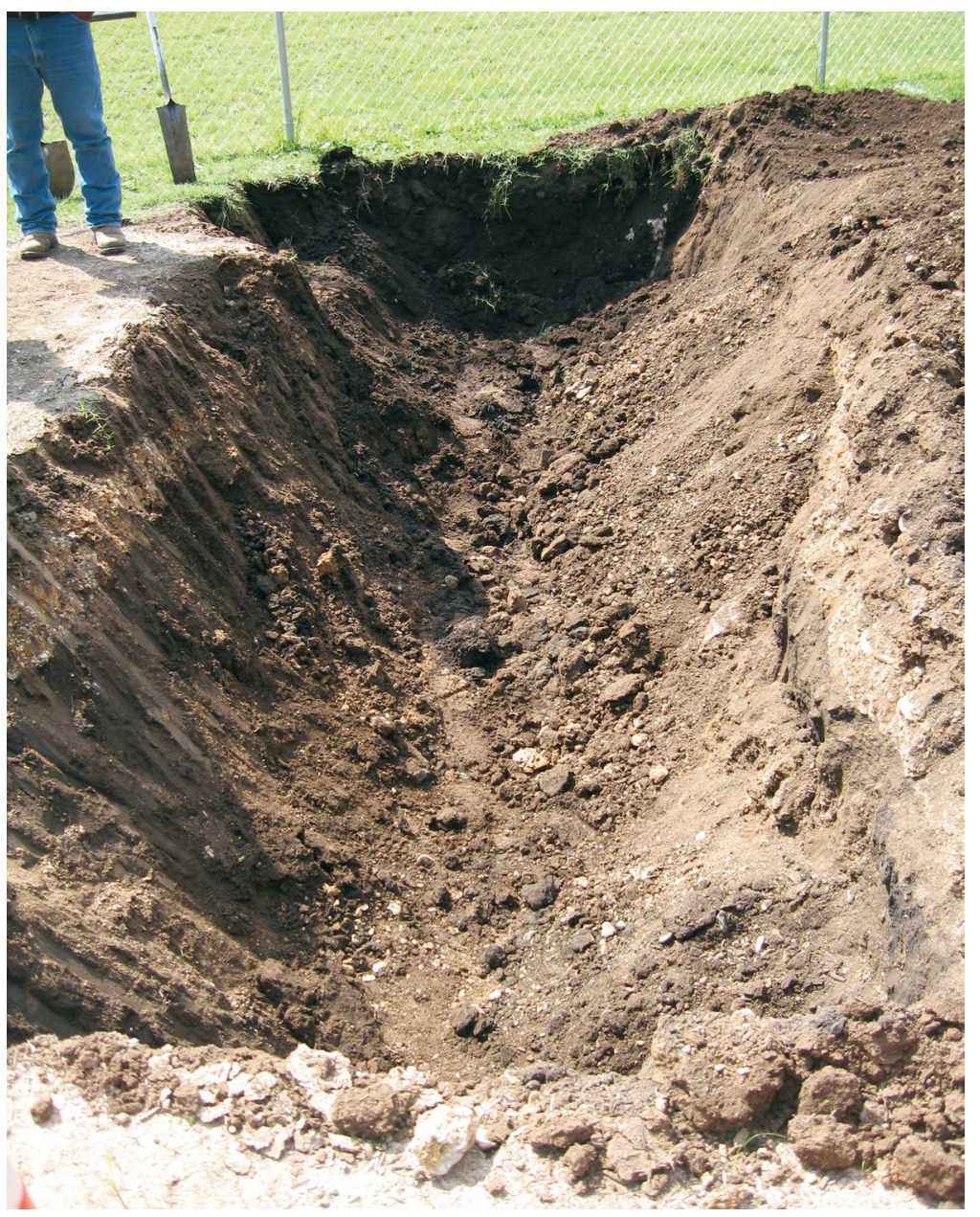

Figure 8-7. Exploratory trench for main water line, looking south.

personnel, it was decided that the waterline, which no longer served any existing facility on the Spring Lake peninsula, would simply be abandoned in situ and an alternate method would be devised for providing water to the new construction.

\section{IrRigation Line Monitoring}

After the decision was made to abandon the main waterline because of the destructive nature of the excavations required for relocating it, TxSt decided to recommission an old irrigation line for the purpose of providing potable water to the ticket kiosk restroom facility. This existing line is located on the northwest side of the paved peninsula road. On May 24, 2012, CAS archaeologists monitored the installation of a meter box located in a grassy area between the paved peninsula road and the Rivers System Institute parking lot, northeast of the new ticket kiosk and restroom facility. After some manual excavations with shovel around the area, a hydro-excavator was used to remove the sediment on top of and around an existing waterline. 
The final depth of the area excavated with the hydro-excavator measured approximately $1 \mathrm{~m}$ below surface. A small amount of debitage was observed within the first $10 \mathrm{~cm}$ of the scraped sediment; however most of the sediment excavated with the hydro-excavator had been previously disturbed by the initial installation of the waterline. In addition, a trench measuring $1 \mathrm{~m}$ in length and running east from the pipe was excavated by hand to a depth of $33 \mathrm{cmbs}$ (Figure 8-8). This trench contained more debitage and one core fragment.

On May 30, 2012, two more relatively small trenches and one pit were required to reactivate the line and connect it with the plumbing system of the new facility. The first trench was excavated with a backhoe and was located approximately $5 \mathrm{~m}$ south of the lift station, perpendicular to an existing exploratory trench. This trench was approximately $5 \mathrm{~m}$ long and $0.50 \mathrm{~m}$ deep. The top 10-20 $\mathrm{cm}$ of the excavation consisted of gravelly fill that blankets the surface in the area. Beneath this fill was an intact A horizon that contained burned and firecracked rock, lithic debitage, two stone tool fragments, and a small amount of faunal bone. In

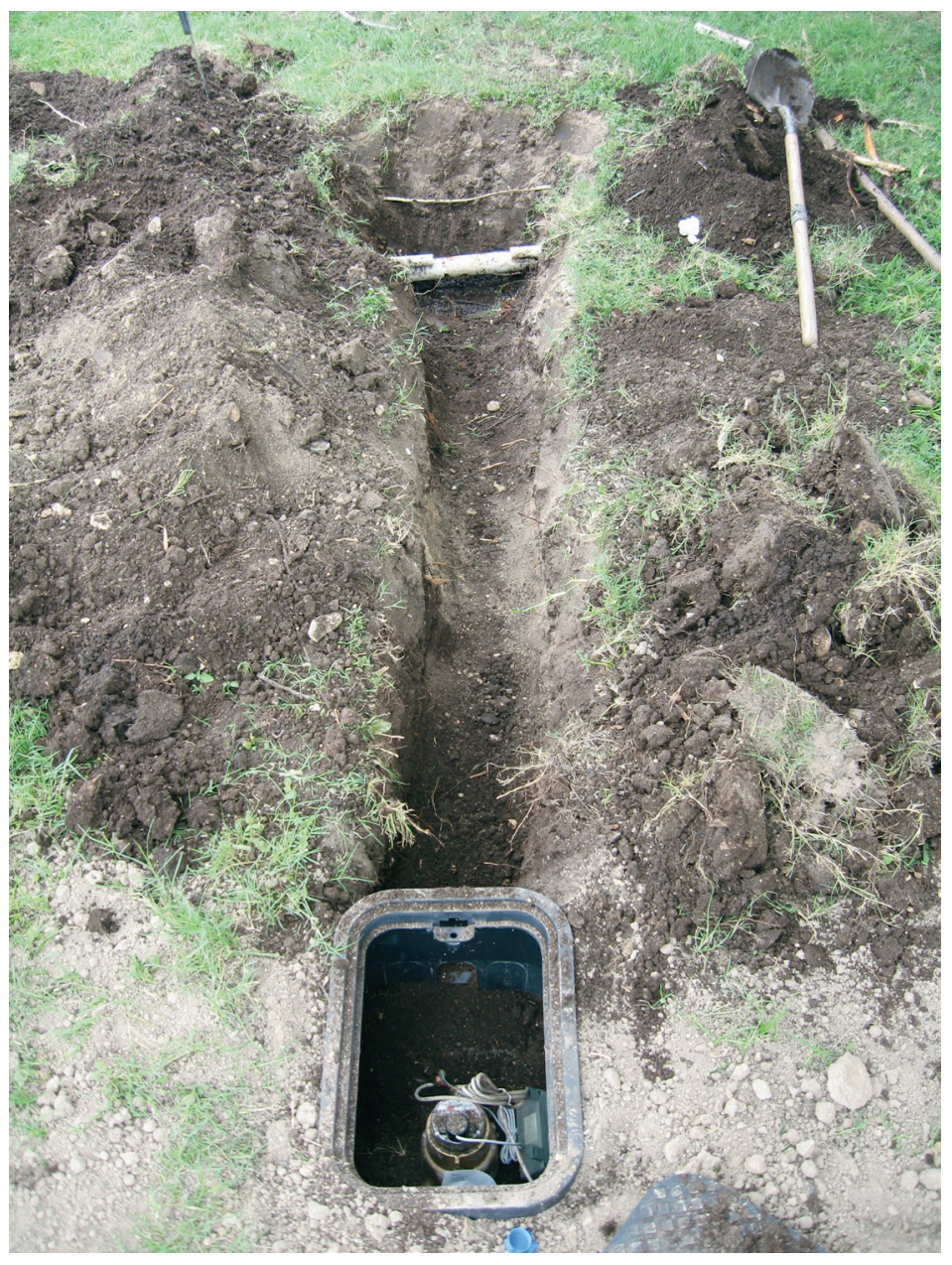

Figure 8-8. Meter box and trench, facing east. 


\section{Chapter 8}

addition to this linear trench, a $1 \times 1.5 \mathrm{~m}$ pit was excavated to the same depth in search of the connection to the facility's infrastructure. Much of the sediment had been disturbed previously, but some intact soil containing similar cultural material was encountered.

The second trench was excavated manually just north of the driveway to the parking lot. This trench was excavated to expose the targeted irrigation line in order to connect it with an adjacent meter box. This excavation resulted in a trench that measured approximately $2.5 \mathrm{~m}$ long and about $25 \mathrm{~cm}$ deep (Figure 8-9). Three small pieces of lithic debitage were encountered in this excavation. Overall, impact to previously undisturbed sediment and soil in this area was kept to a minimum and cultural materials observed were consistent with what has been archaeologically exposed previously in this area. No cultural materials were collected.

\section{Walkway and Access Drive Monitoring}

On June 27, 2012, CAS archaeologists monitored preparatory excavations associated with a walkway between the ticket kiosk and restroom facility and the access drive. The project area was crescent shaped with a radius of approximately $10 \mathrm{~m}$ (Figure 8-10). This work consisted

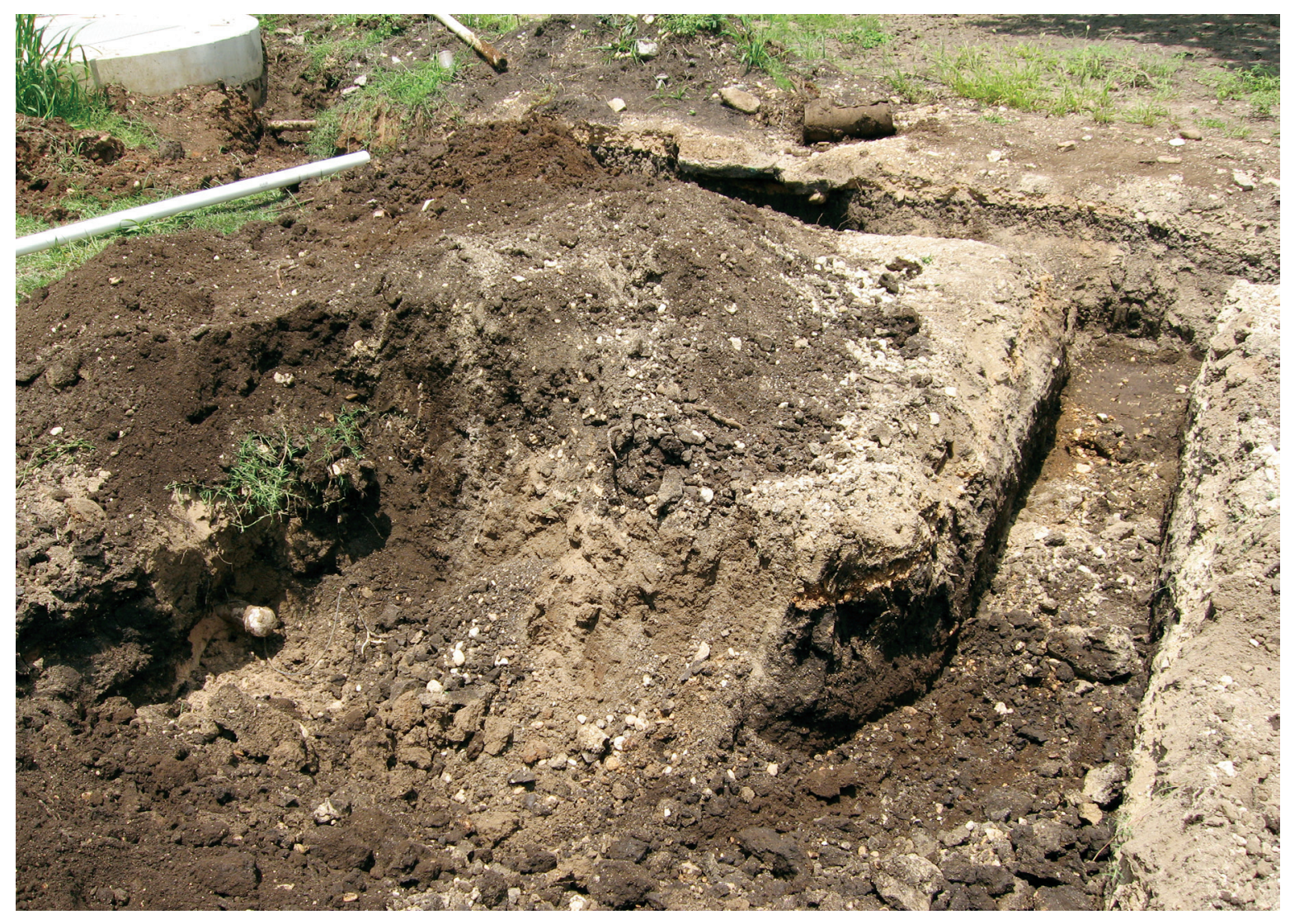

Figure 8-9. Two trenches and one pit for connecting restroom facility with lift station, visible in top left of photo, with new recommissioned irrigation line, facing north. 


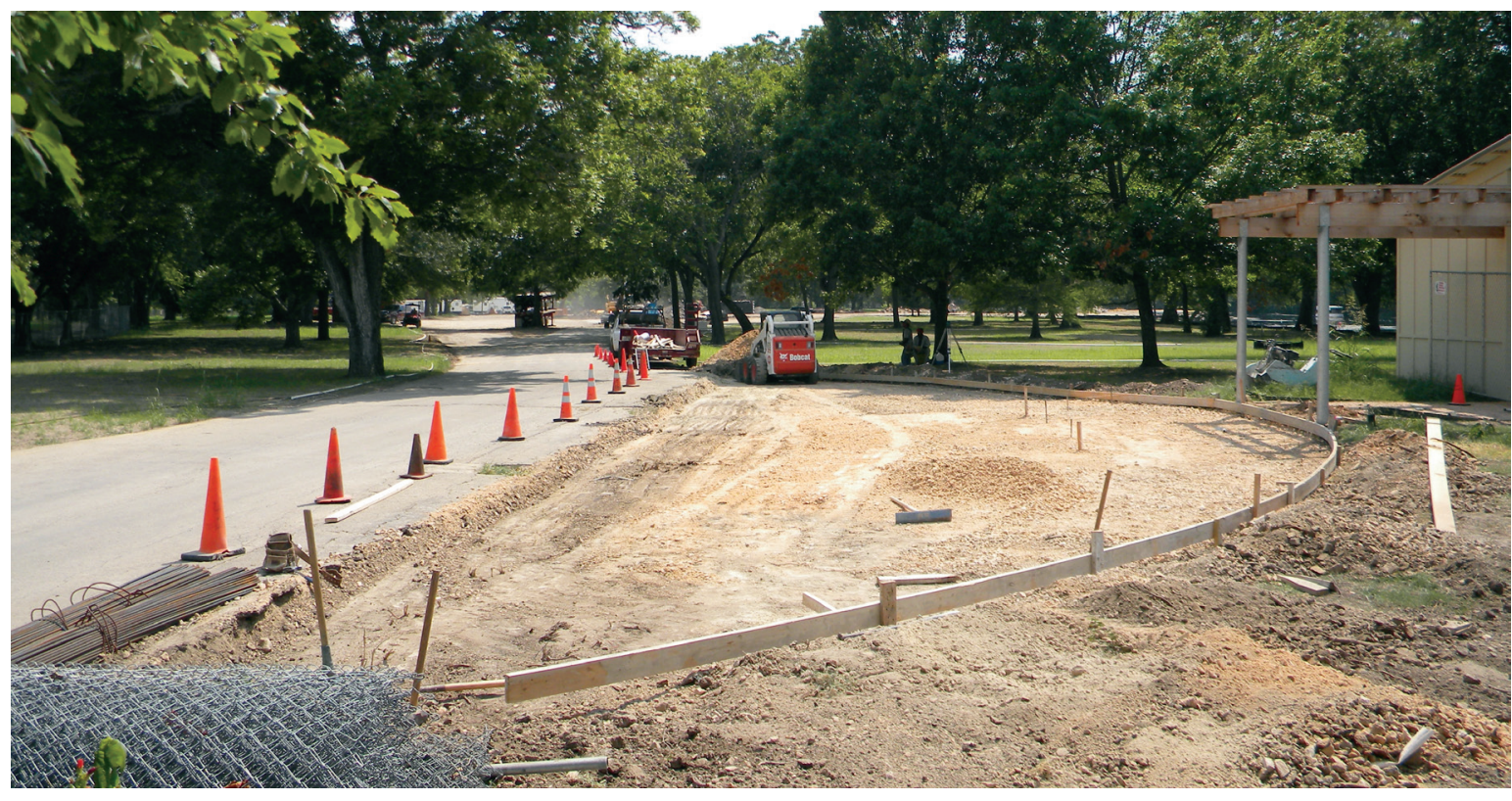

Figure 8-10. Overview of crescent-shaped access drive, looking southwest.

of removing approximately $20 \mathrm{~cm}$ of sediment from the ground surface. This project area had previously been impacted by various developments in that particular location, and as a result most of the sediment scraped during the current project was gravelly construction base/fill. However, small patches of intact sediment were present that contained modern and historic refuse as well as lithic debitage. No diagnostic prehistoric material or significant features were encountered and impact to archaeologically meaningful sediment was minimal.

\section{Burial Documentation, Excavation, and Analysis}

As described above, archaeological monitoring during the trenching to install electrical utilities documented a feature of piled stone that was considered unusual for this section of the cultural deposits present here. Additional investigation revealed a human interment, causing all work in the immediate vicinity to halt in accordance with Chapter 711 of the State of Texas Health and Safety Code concerning the discovery of an unmarked cemetery. In order to test for additional interments, archaeologists from the Texas Historical Commission (Tiffany Osborn and Mark Denton) performed a ground penetrating radar (GPR) survey of a $9 \times 7 \mathrm{~m}$ area over the location of the burial in order to determine whether any other anomalies might be present that could represent additional burials. This survey involved transects at $50 \mathrm{~cm}$ intervals and recording return signals that were differentially reflected from subsurface strata and other deposits, including possible rock features (Figure 8-11). One faunal bone specimen (a tooth) and three projectile points were collected from the surface of the surveyed area. Two of the projectile points were identified as Pedernales (see Figure 7-7 B and C), and the other exhibited extensive thermal damage and was therefore not typable (see Figure 7-15: 54-1). 


\section{Chapter 8}

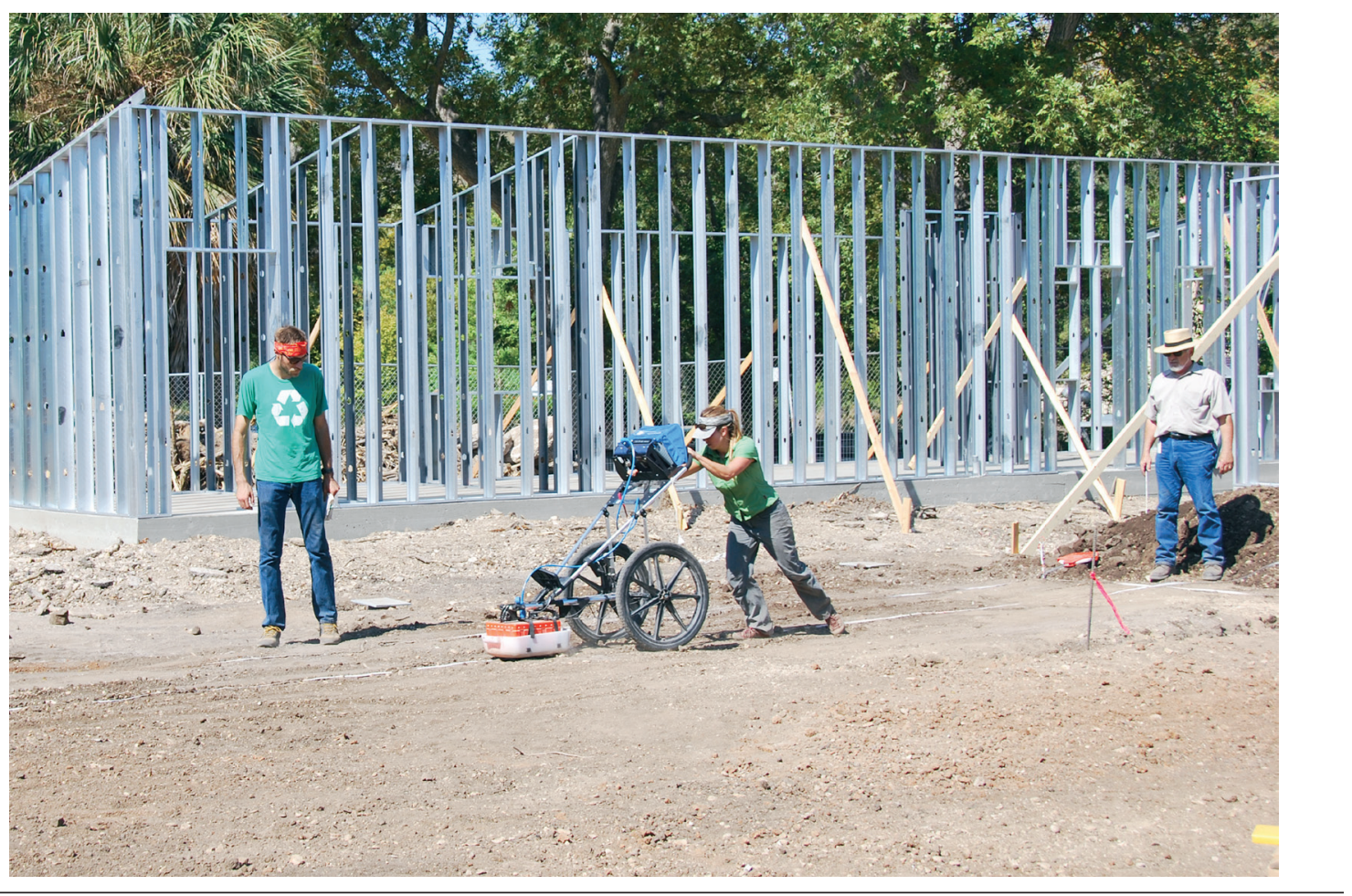

Figure 8-11. THC archaeologist Tiffany Osborne conducting GPR survey of area around burial location.

In addition to the known burial with its intact cairn, only one additional anomaly was identified during the GPR survey. This area was located immediately adjacent to the electric utility trench where the burial was identified. Sediments overlying this possible feature were carefully removed by mechanical excavation, and then hand excavation commenced until the feature was exposed. Upon excavation, the anomaly was determined be a burned rock feature rather than a burial. It was preliminarily documented, and a Bulverde projectile point was recovered from immediately adjacent to the feature (see Figure 7-7 A). The feature was reburied and remains largely intact at the site. Other items collected during the mechanical excavation include faunal bone and one ceramic fragment (see Figure 7-34: 58-1).

This work constituted the discovery phase of the burial documentation process. Once it was confirmed that only a single burial was present, TxSt filed a Notice of the Existence of a Cemetery at the office of the Hays County Clerk in compliance with the Texas Health and Safety Code. This notice was filed on September 19, 2011. Ensuing discussions with TxSt project designers indicated that this location would be a high pedestrian traffic area once the construction was completed. It was recommended that this was an inappropriate locale for a prehistoric interment, and the decision was made to remove the remains with the ultimate intent of reinterring them elsewhere at Spring Lake following appropriate analyses and consultation with Native American tribes as required under the Native American Graves Protection and Repatriation Act. As a result of these decisions and with support from the 
Office of the State Attorney General, TxSt simultaneously petitioned the Hays County District Court to vacate the cemetery designation and grant permission to remove the remains, and the Office of the State Registrar to issue a permit to disinter the remains that were present. The cemetery designation was lifted and permission to remove the remains granted on November 30, 2011. The State Registrar's Office issued a disinterment permit on December 1, 2011.

\section{Burial Excavation}

On December 5, 2011, CAS archaeologists relocated the fabric covering that had been placed over the remains and began a controlled excavation. This excavation was preceded by a Native American blessing offered by Dr. Mario Garza of the Miakan/Garza band of Coahuiltecans, which is based locally in San Marcos. A small block measuring approximately $1 \times 1 \mathrm{~m}$ in size was laid out over the precise area where archaeologists expected the remainder of the body to be located based on the location and orientation of the cranium. This unit was placed immediately adjacent to and west of the trench, and included the cairn feature (Figure 8-12). Vertical control for the excavation was provided by an elevation datum established near the edge of the unit and that was tied into the elevation datum used for Units 3 and 4.

FIGURE REDACTED

Figure 8-12. Excavation unit $(1 \times 1 \mathrm{~m})$ for burial excavation, facing south. 
Measurements taken from this datum defined the beginning and ending elevations of each excavation level. Arbitrary $10 \mathrm{~cm}$ levels were excavated by hand and screened through a $1 / 4$-inch wire mesh screen. Artifacts observed on the screen were collected and cataloged by provenience. Similar to other controlled excavations at the site, documentation consisted of a daily journal, scaled drawings, level summary forms, and digital photographs. Once the skeletal remains were completely exposed, they were photographically recorded and also plotted on a scaled plan drawing (Figure 8-13). Carbon samples were recorded and collected in situ and from the screen, and sediment samples were collected from inside and around the remains. The location of the burial was recorded with a GeoXT hand held GPS system with sub-meter accuracy and integrated into a database of Spring Lake cultural resources.

\section{Cultural Material}

A total of 2033 artifacts and 174.23 grams of faunal bone were recovered from the burial excavation (Table 8-2). None of the artifacts recovered is considered ornamental or symbolic, and none is clearly associated with the burial in a way that would allow designation as ceremonial or grave offerings. However, four projectile points and point fragments were recovered during these excavations (Figure 8-14). None is thought to be an offering that accompanied the burial. Rather, all are presumed to have been included in sediment matrix that was collected from nearby or that was somehow displaced during the burial event. Specimen 503-3 is a Marshall point indicative of early Late Archaic occupation, and Specimen 504-1 is a Fairland point indicating occupation during the Late Archaic III. Specimen 505-9 is the proximal end of an untypable projectile point that resembles an early-stage Nolan point with a very slightly beveled stem. Specimen 506-1 (not illustrated) is an untypable medial fragment.

Table 8-2. Cultural Material from Burial Unit

\begin{tabular}{lrc}
\hline \multicolumn{1}{c}{ Cultural Material } & Count & Weight \\
\hline Lithic Debitage & 1187 & 1368.6 \\
Lithic Biface & 3 & 113.46 \\
Lithic Uniface & 1 & 17.82 \\
Projectile Point & 4 & 46.3 \\
Burned Rock & 325 & 9498.38 \\
Burned Clay & 469 & 530.94 \\
Charcoal & 20 & - \\
Mussel Shell & 24 & 4.6 \\
Faunal Bone & - & 174.23 \\
\hline
\end{tabular}


FIGURE REDACTED

Figure 8-13. Plan view illustration of burial feature and associated artifacts.
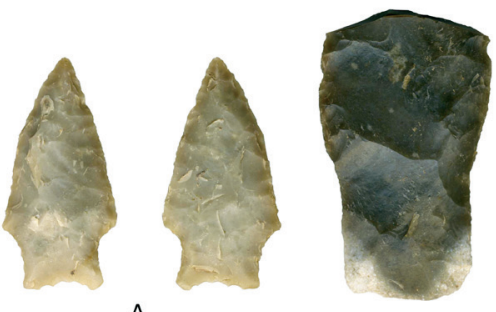

A

B
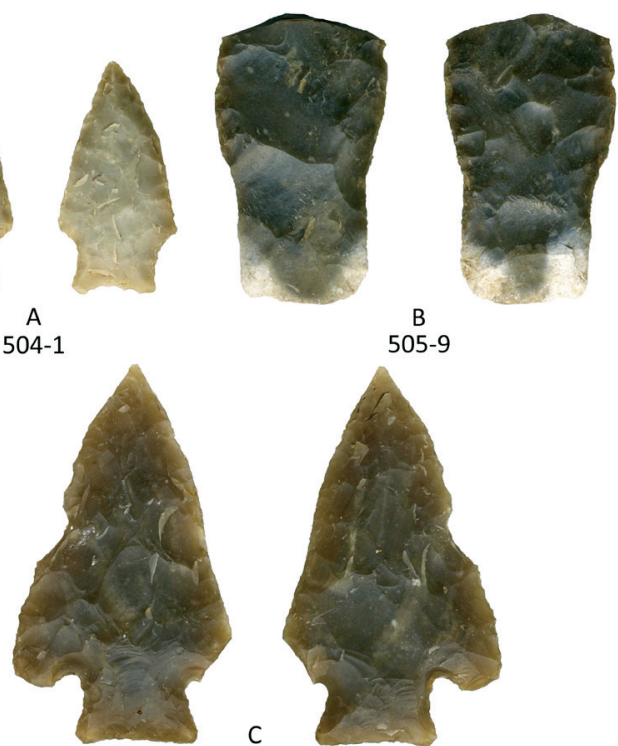

503-3

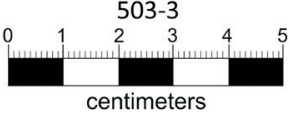

Figure 8-14. Three projectile points from burial excavation. 


\section{Bioarchaeological Analysis}

\section{by Michelle D. Hamilton and M. Katherine Spradley}

Osteological analyses of the remains was conducted in order to help determine important aspects of the cultural ancestry and possible origin of this individual for scientific reasons and also to provide better documentation of the remains for the purposes of Native American consultations required under NAGPRA. The osteological investigation was conducted by Drs. Kate Spradley and Michelle Hamilton of the Department of Anthropology at TxSt, with the additional osteological cleaning, sorting, and reconstruction assistance of four graduate students (C. Figueroa-Soto, M. McClain, L. Springs, and C. Tegtmeyer).

Following excavation, the skeletal remains were transported to CAS using a variety of storage media, including encasment in soil matrix and placement in foil-wrapped packages, cardboard containers, and within re-sealable zipper plastic storage bags. Once in the lab, all materials were kept stored in a securely locked private room in the CAS curation facility, and all analyses described below took place within this context. All foil pouches, containers, and plastic bags were opened, inspected, and brushed free of adhering soil matrix when possible. The bones were extremely friable and fragile, and as a result the skeleton was in a moderateto-extreme state of fragmentation. Where possible, skeletal elements were reconstructed for analytical purposes using non-permanent soluble adhesive glue. Bone taphonomy, including patina and wear present on all human skeletal elements, is typical of an extended earthen burial. The skeletal elements are stained light to dark brown in color except in areas of postmortem fracturing, where the breaks are lighter in color as expected.

Due to the fragile and fragmentary nature of the skeletal remains, reconstruction and analysis was difficult. It is estimated that while most of the skeleton is represented, it is fragmented into thousands of elements. Limited reconstruction was attempted on a number of target elements in an effort to provide information towards estimating the biological profile. The fragmentary nature of the remains largely precludes osteometric and craniometric data measurement collection, although limited postcranial measurements were collected on long bones where possible or feasible. The results of the osteological analysis are as follows (Table 8-3).

Table 8-3. Skeletal Analysis Summary

$\begin{array}{ll}\text { Age } & \text { Adult }(25+) \\ \text { Sex } & \text { Male } \\ \text { Stature } & 63.0^{\prime \prime}-70.1^{\prime \prime} \\ \text { Affiliation } & \text { Prehistoric Native American; specific tribal affiliation undetermined } \\ \text { Trauma } & \text { Restricted to antemortem }\end{array}$




\section{Minimum Number of Individuals (MNI): One}

No repeated bone elements were recovered from this burial. All elements are adult in age and do not present overlapping morphological indicators of varying age ranges. Additionally, all elements that were utilized for sex estimation point toward a single sex represented. Based on burial presentation, archaeological recovery records, context, and observations of the elements present, the MNI from the burial at 41HY160 represents a single individual.

\section{Sex: Male}

Due to the state of preservation, sex was estimated using limited visual observations. The pelvis is the most effective visual indicator of sex in the human skeleton; however it was not possible to utilize pelvic morphology for sex estimation due to the extreme fragmentation and damage to the region. Although the cranium and mandible were fragmented, there were a number of morphological indicators present that are indicative of sex, including a blunt chin and flared/everted gonial angles on the mandible and a robust brow ridge, which typically reflect masculine features. Other features on the skull were inconclusive, however, including average mastoid size, and gracile nuchal and other muscle regions. Long bones have pronounced areas of musculature (i.e., deltoid tuberosity on the humerus, linea aspera on the pelvis) that are also indicative of male sex.

\section{Age: Adult}

Skeletal age at death is determined via a detailed multifactoral approach utilizing macro- and microscopic changes in selected bone structures. Certain bones or bone features are target elements for assessing adult age and include dental maturation and eruption, epiphyseal closure, articular joint morphology, and degenerative changes to the skeleton.

While the morphology of the pubic symphysis and auricular surface were not available owing to the damaged and fragmentary nature of those elements, the remaining observable indicators of age are all suggestive of an adult individual. No unfused epiphyses or epiphyseal lines are present. The sternal end of one clavicle is present and fused, the tooth roots are fully developed, and the third molars erupted. Tooth wear is severe and reflective of an adult pattern. This gives a general starting age range of 25 years+.

There is slight osteophytic overgrowth on the left ulna and on a few vertebral bodies. In general, however, there is an overall lack of observable degenerative changes on the joint surfaces present. This indicates that age-related arthritic and degenerative changes, which tend to begin in middle adulthood barring trauma or injury, have not yet initiated.

A wedge fracture (compression fracture) is present on two vertebral bodies, likely resulting from injury versus age-related bone loss. This assessment is based on the youthful appearance of most of the skeleton and the lack of other age-related trauma indicators.

All observed features on the skeleton characterize this individual as an adult. By recent forensic standards this individual would be considered 25-35 years of age, but given the 


\section{Chapter 8}

differences in activity patterns and lifeways between prehistoric and modern populations, the age estimation of this individual is given simply as younger "adult" (versus middle to older aged).

\section{Stature}

Intact postcranial long bone elements are necessary for estimating stature. This individual had an intact clavicle, left radius, and left ulna, and it was possible to reconstruct one femur. All other elements were too fractured to provide valid stature estimates. Although stature estimation formulae exist for indigenous population groups from North America (Auerbach and Ruff 2010), the full suite of measurements necessary to apply them are not available due to the fragmentary nature of the remains. Therefore, FORDISC 3.1 stature reference standards were

used. The stature of this individual is estimated to fall within a range of 63.0"-70.1" (Jantz and Ousley 2005). Although this estimate is generated using modern forensic reference data, the equation is not population specific and uses a regression equation with a 90 percent prediction interval. Because this estimate is not generated from population specific or temporally specific data, it is intended to serve only as a general indicator of stature.

\section{Ancestry}

Burial context, associated artifacts, archaeological data, biological indicators, and overall taphonomic appearance all point towards a prehistoric Native American determination with regard to cultural and biological affiliation. Specific biological indicators of Native American affiliation include the following. The dentition (Figure 8-15) demonstrates extreme occlusal tooth wear on the premolars and molars (within a range of stages $6-8$ ), with the patterning and degree consistent with prehistoric hunter-gatherer populations (Smith 1984).

The cranial and postcranial skeleton provides reliable estimates of ancestry, due to the heritability of skeletal traits, using multivariate statistical approaches. Based on the incomplete and fragmentary nature of the cranium, further craniometric analysis is not possible. However, postcranial ancestry estimation was employed using the Goldman Data Set (Auerbach and Ruff 2004) for comparative reference data. In bioarchaeological analyses, when the context of Native American is known a priori, statistical comparison of the unknown (isolated burial) to known Native American groups is useful in assessing biological relationships to other groups. Due to the fragmentary nature of the remains, only a limited number of postcranial elements were available for measurement (Table 8-4).

The comparative groups (Table 8-5) were chosen based on availability of postcranial data. First a discriminant function analysis was run to generate a Mahalanobis squared distance $\left(\mathrm{D}^{2}\right)$ matrix using SAS 9.1.2. Mahalanobis distance is a measure of biological similarity between groups. For the purposes of the present analysis, $41 \mathrm{HY} 160$ was input as a single reference group, in order to obtain a $\mathrm{D}^{2}$ value. Next, the $\mathrm{D}^{2}$ was double centered, to remove effects of small sample sizes and the resulting eigenvectors were extracted and plotted in two dimensions to view the biological distances between all reference groups and 41HY160. 
Table 8-4: Available Metric Data of Skeletal Remains*

\begin{tabular}{|c|c|c|}
\hline Description & Side & Measurement in mm \\
\hline Clavicle Maximum Length & Left & 155 \\
\hline Clavicle A-P diameter at midshaft & Left & 11 \\
\hline Clavicle Sup-Inf diameter at midshaft & Left & 9 \\
\hline Humerus epicondylar breadth & Right & 62 \\
\hline Humerus maximum diameter at midshaft** & Right & 22 \\
\hline Humerus minimum diameter at midshaft** & Right & 20 \\
\hline Radius maximum length & Left & 228 \\
\hline Radius A-P diameter at midshaft & Left & 11 \\
\hline Radius M-L diameter at midshaft & Left & 12 \\
\hline Ulna maximum length & Right & 268 \\
\hline Ulna A-P diameter & Left/Right & $14 / 16$ \\
\hline Ulna M-L diameter & Left/Right & $16 / 18$ \\
\hline Ulna physiological length & Left & 241 \\
\hline Femur A-P subtrochanteric & Right & 28 \\
\hline Femur M-L subtronchanteric & Right & 31 \\
\hline Femur A-P midshaft diameter & Right & 33 \\
\hline Femur M-L midshaft diameter & Right & 26 \\
\hline Tibia maximum length & Left & 389 \\
\hline Tibia maximum diameter at nutrient foramen & Right & 39 \\
\hline Tibia minimum diameter at nutrient foramen & Right & 24 \\
\hline \multicolumn{3}{|c|}{$\begin{array}{l}\text { The osteometrics presented in this table incorporate all the standard osteometric data out- } \\
\text { ined in Buikstra and Ubelaker (1994). Both sides were recorded where possible. }\end{array}$} \\
\hline *** slightly estimated & & \\
\hline
\end{tabular}


Chapter 8

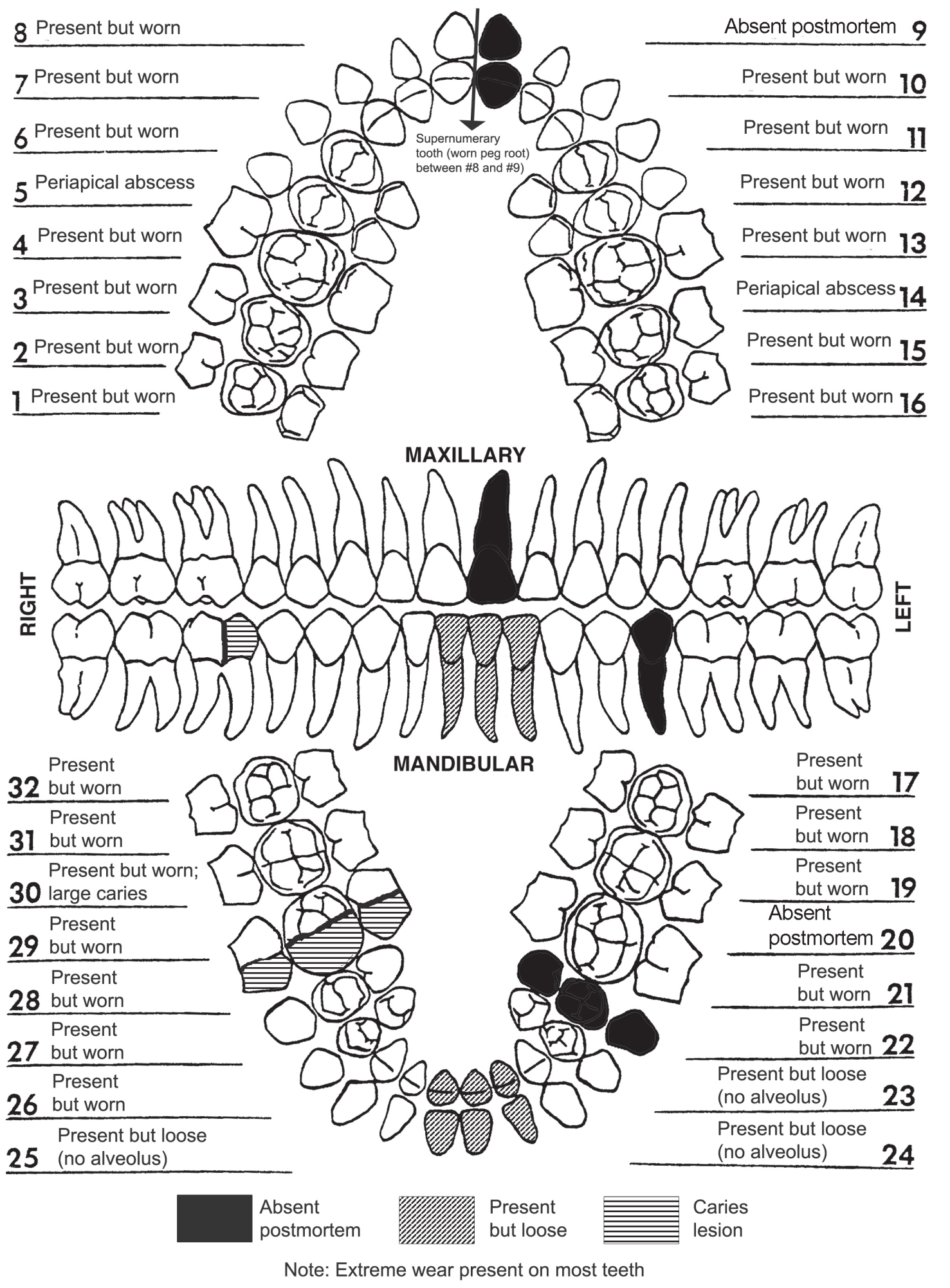

Figure 8-15. Dental inventory of burial from Ticket Kiosk excavation. 
Table 8-5. Native American Comparative Groups for Ancestry Analysis*

\begin{tabular}{lc}
\hline \multicolumn{1}{c}{ Group and Geographic Origin } & N \\
\hline Alaska & 31 \\
Aleutian, Alaska & 17 \\
Cliff Dweller, Utah & 12 \\
Indian Knoll, Kentucy & 25 \\
Illinois & 21 \\
Santa Cruz, California & 5 \\
Southwest, New Mexico & 34 \\
South Dakota & 27 \\
\hline
\end{tabular}

*data described in Auerbach and Ruff 2004

The resulting plot (Figure 8-16) shows 47 percent of the total variation. The first axis separates 41HY160 from all other groups and the second axis separates the Alaska and Aleutian groups from all other Native American groups and 41HY160. The isolated position of the Spring Lake burial is likely due to the absence of comparative groups from the Texas region.

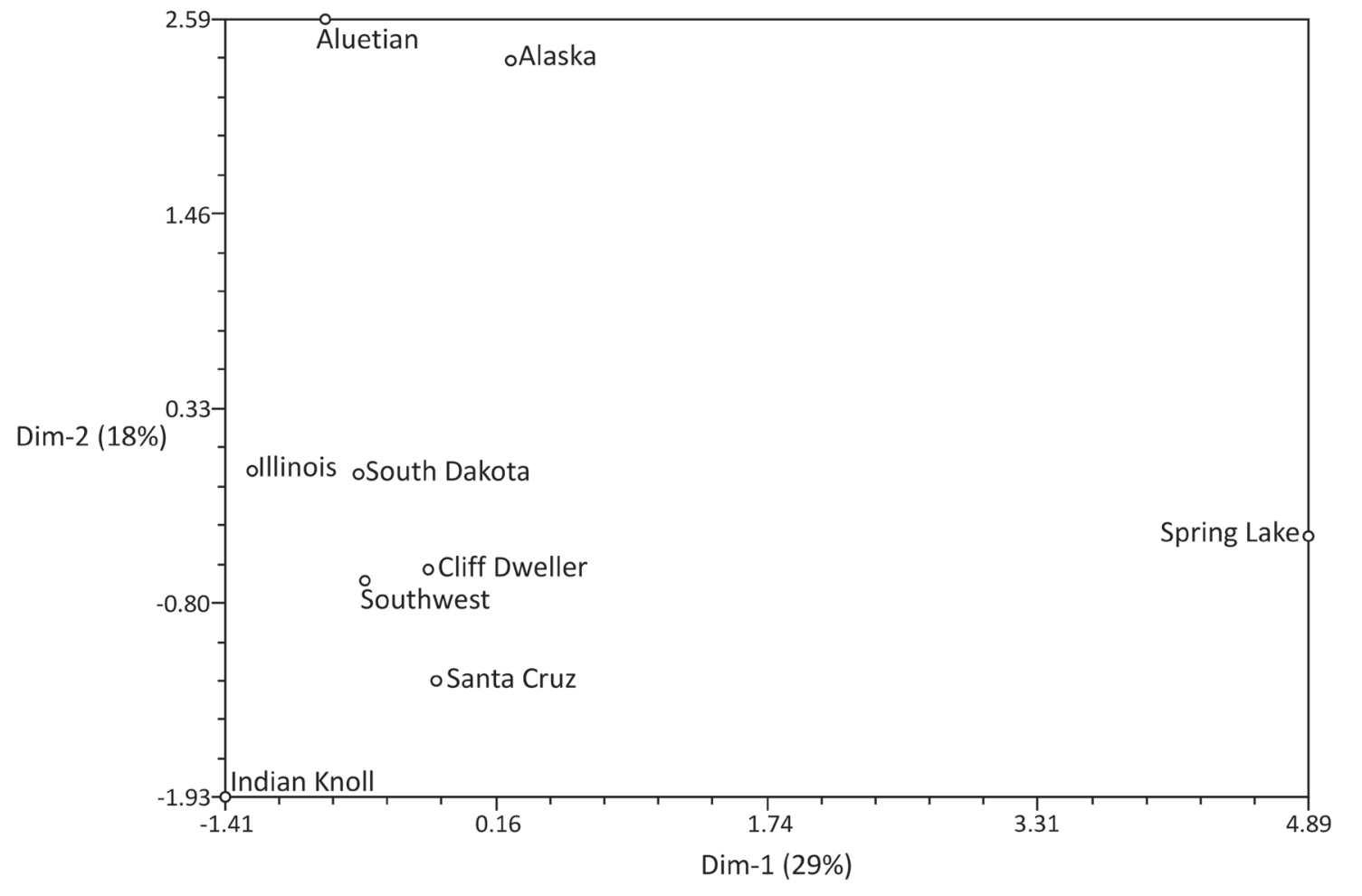

Figure 8-16. Two-dimensional plot of D2 matrix. 


\section{Trauma}

Trauma and pathology present on the skeleton are restricted to antemortem (those occurring prior to death) injuries composed of a vertebral wedge fracture and slight osteoarthritic lipping (see "Age" section), as well as dental caries. All other trauma observed on the remains appears consistent with postmortem damage.

\section{Summary}

Morphological indicators that can be used to assess sex and age indicate that this individual is an adult male. No assessments for cultural affiliation beyond "Native American" can be made as a result of the fragmentary and incomplete nature of the remains.

\section{Isotopic Analysis}

by Jon C. Lohse*

To help determine possible cultural affiliation, a small sample of the burial was subjected to radiocarbon dating (to determine the archaeological age of the individual) and to isotopic analyses (in order reconstruct some aspects of this person's prior dietary history). Stable carbon isotopes were measured from both collagen and hydroxylapatite carbonate (apatite), the organic and non-organic fractions of bone composition, respectively. Stable nitrogen isotopes were measured on apatite from the same bone sample. Together, these three values $\left(\mathrm{C}_{\mathrm{COL}}, \mathrm{C}_{\mathrm{AP}}\right.$, and $\mathrm{N}_{\mathrm{COL}}$ ) provide a reasonably complete understanding of prehistoric diet, which is strongly correlated in some cases with the distinct geographic environment inhabited by a person. Additionally, oxygen isotopes were measured from the same sample of bone apatite utilized for the carbon and nitrogen analyses. The primary source of oxygen that becomes incorporated into skeletal structure is drinking water, and this analysis can help place prehistoric people geographically by linking populations with known sources of water.

\section{Overview of Isotope Studies}

Research has indicated that a history of diet can be reconstructed based on different chemical compounds from different parts of a person's body (Ambrose 1990, 1991). For example, the chemical makeup of bone includes both collagen and apatite. Isotopic ratios in collagen indicate protein (fish, meat) consumption through time, while apatite ratios include carbohydrate consumption and tend to be a better overall reflection of total diet rather than only the protein component of a diet, although relationships are complex (see Kellner and Schoeninger 2007). Both collagen and apatite are continually reabsorbed into the body, meaning that a person's isotopic composition as measured in bone will be an average reflection of diet over the several years prior to his/her death.

*Much of the work in this section about isotopic analysis builds on earlier research on this topic performed

by Raymond P. Mauldin and his colleagues at UTSA, and I wish to acknowledge his intellectual contributions to this part of the report.. 
During photosynthesis, stable carbon isotopes $\left({ }^{12} \mathrm{C}\right.$ and $\left.{ }^{13} \mathrm{C}\right)$ and nitrogen $\left({ }^{14} \mathrm{~N}\right.$ and $\left.{ }^{15} \mathrm{~N}\right)$ are integrated into plant tissues. Plants have the ability to obtain stable nitrogen isotopes atmospherically or from the soil. Herbivores ingest these elements into their tissues, which are then consumed by carnivores and omnivores. In humans, the ratios of stable carbon isotopes in bone collagen and apatite, and ratios of nitrogen isotopes in bone collagen, mirror, with minor fractionations (changes resulting from photosynthesis or movement from one level to the next up the food chain), the isotopic compositions of the diet. However, dietary reconstruction from isotopic data in humans is complex, due in part to variances in how the carbon isotopes of different food components (e.g., proteins vs. carbohydrates) are incorporated into bone tissues (Ambrose and Norr 1993; Norr 1995).

Plants, which form the base of the food chain, take in atmospheric carbon dioxide $\left(\mathrm{CO}_{2}\right)$ through different photosynthetic pathways that discriminate between ${ }^{12} \mathrm{C}$ and ${ }^{13} \mathrm{C}$. In one pathway, $\mathrm{CO}_{2}$ is incorporated into a six-carbon compound that converts rapidly to a threecarbon compound called 3-phosphoglyceric acid. This photosynthetic pathway, commonly referred to as $\mathrm{C} 3$, is also known as the Calvin cycle. In a second pathway, however, $\mathrm{CO}_{2}$ is first incorporated into four-carbon compounds prior to transfer to sugars. Plants following the C4 photosynthetic pathway are typically of tropical origins, favor warm climates, and tend to produce two to three times are much dry matter as plants of the C3 pathway. C3 plants discriminate against ${ }^{13} \mathrm{C}$ while $\mathrm{C} 4$ plants take in greater amounts of ${ }^{13} \mathrm{C}$. $\mathrm{C} 3$ and $\mathrm{C} 4$ plants can therefore be differentiated based on their ratios of ${ }^{13} \mathrm{C}$ to ${ }^{12} \mathrm{C}$, reported in parts per mil as $\delta^{13} \mathrm{C}$, with $\mathrm{C} 4$ plants having proportionally more ${ }^{13} \mathrm{C}$. A third photosynthetic pathway, called crassulacean acid pathway or CAM, is common to water-bearing succulents such as agave that are common in arid regions. Plants following a CAM pathway follow a C4-like pathway, with similar $\delta^{13} \mathrm{C}$ values.

Human bone collagen has been estimated to have stable carbon isotope values, measured as $\delta^{13} \mathrm{C}$, approximately 5\% (parts per mil) greater than the values reflected in the protein portion of their diet (Ambrose and Norr 1993; Krueger and Sullivan 1984; Tykot 2004). Interpretations of variation in the ratio of stable nitrogen isotopes $\left(\delta^{15} \mathrm{~N}\right)$, which are only present in bone collagen, are underdeveloped. It appears that $\delta^{15} \mathrm{~N}$ values in human bone collagen are approximately equivalent to the animal flesh consumed and 2-3\%o greater than nitrogen values of consumed plants (Ambrose and DeNiro 1986; Schoeninger and DeNiro 1984). $\delta^{15} \mathrm{~N}$ values in humans that consume primarily terrestrial plants and animals range from about 6 to 10\%, while those that primarily rely on marine resources are between 15 and 20\% (Tykot 2004). $\delta^{13} \mathrm{C}$ is measured in relation to a universal standard, the Cretaceous-age Pee Dee Belemnite (PDB) marine fossil formation in South Carolina while the universal standard for comparing $\delta^{15} \mathrm{~N}$ is air (AIR).

Unlike carbon and nitrogen, stable oxygen isotopes reflect sources of water, which are influenced by precipitation, ground water, and temperature and humidity. Excellent overviews of techniques for and requirements of using oxygen isotopes are found in Parks (2009), White 


\section{Chapter 8}

et al. (1998), White et al. (2000), and White et al. (2004). Oxygen is measured as the ratio between ${ }^{18} \mathrm{O}$ and ${ }^{16} \mathrm{O}$, reported as $\delta^{18} \mathrm{O}$, and, like carbon and nitrogen, is expressed in parts per thousand (\%o). The resulting $\delta^{18} \mathrm{O}$ value is calculated in relation to different standards depending on the material sampled. $\delta^{18} \mathrm{O}$ increases with frequency of the heavier ${ }^{18} \mathrm{O}$ and is affected by a number of different natural and metabolic processes. For example, the $\delta^{18} \mathrm{O}$ of water consumed by obligate drinkers (animals, especially people, that consume most of their water directly from a source rather than through diet) declines with distance from coastal margins, with increasing elevation, and by northerly latitude. While metabolic rates specific to different species can affect $\delta^{18} \mathrm{O}$, variation within populations that do not travel across large distances is seen to be generally very low, approximately $1 \%$.

$\delta^{18} \mathrm{O}$ can be measured in phosphates $\left(\delta^{18} \mathrm{O}_{\mathrm{p}}\right)$ and carbonates $\left(\delta^{18} \mathrm{O}_{\mathrm{C}}\right)$, both of which occur in bone and in teeth. The standard against which phosphate samples are compared is Vienna Standard Mean Ocean Water (VSMOW), while carbonate samples are compared against the carbonate standard PBD. Phosphate-oxygen ratios $\left(\delta^{18} \mathrm{O}_{\mathrm{P}}\right)$ range from $10 \%$ to $20 \%{ }_{\text {VSmow }}$ and are considerably higher than carbonate-oxygen ratios $\left(\delta^{18} \mathrm{O}_{\mathrm{C}}\right)$, which range in humans from $0 \%$ to $-10 \% 0_{\mathrm{PDB}}$. Except where diagenesis affects carbonate preservation, $\delta^{18} \mathrm{O}_{\mathrm{P}}$ can be approximately converted to $\delta^{18} \mathrm{O}_{\mathrm{C}}$ by subtracting $21.0 \%$. Unless reporting labs clearly indicate factors involved in this conversion, comparisons of reported data should rely only on similar samples, for instance bone phosphates or teeth enamel. All samples in the present study are $\delta^{18} \mathrm{O}_{\mathrm{C}}$ and were performed on the same bone samples used for $\delta^{13} \mathrm{C}$ and $\delta^{15} \mathrm{~N}$ in order to minimize the use of destructive analytical techniques.

$\delta^{18} \mathrm{O}$ is incorporated into human tissue during mineralization. However, because bone remodels over a period of a few years, $\delta^{18} \mathrm{O}$ from bone samples will reflect the average $\delta^{18} \mathrm{O}$ values over that period of time, essentially creating a record of water consumption that approximately equals that of food consumption using stable carbon and nitrogen values. Prehistoric hunter-gatherers such those who occupied Spring Lake almost certainly tended to forage across potentially large distances, which may complicate attempts to reconstruct territorial ranges using $\delta^{18} \mathrm{O}$. Nevertheless, these data are presented for the entire San Marcos burial assemblage $(n=6)$ as part of the ongoing research to understand and document insofar as possible movements of past peoples into the area.

\section{Results of Isotope Studies}

The single individual recovered during this project was included in the small dataset of prehistoric burials that have been recovered from the San Marcos area. These include two partial remains from 41HY161 and three individuals recovered from 41HY163, the Zatopec

Site (Munoz et al. 2011; Stull and Hamilton 2011). All pretreatments and laboratory processing associated with these analyses was performed by Dr. Raymond Mauldin at the Center for Archaeological Research at the University of Texas at San Antonio. Results of isotope analyses for all of these individuals are presented in Table 8-6. 
Table 8-6. Isotope Data for Burial Population from Three Sites

\begin{tabular}{|c|c|c|c|c|c|c|c|c|}
\hline$\stackrel{D}{\stackrel{*}{*}}$ & 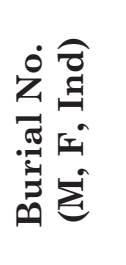 & 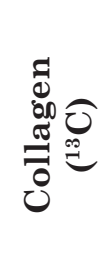 & 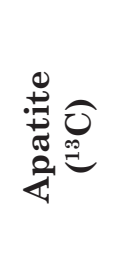 & 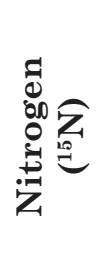 & 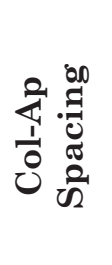 & 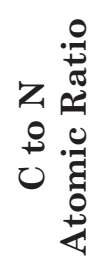 & 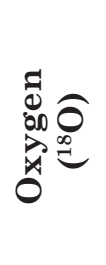 & 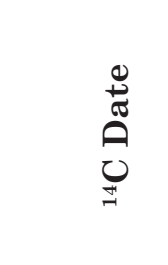 \\
\hline 41HY161 & $1(\mathrm{~F})$ & -10.4 & -7.9 & 13.3 & 2.5 & 3.2 & -2.5 & $515 \pm 20$ \\
\hline 41HY161 & 2 (Ind) & -16.9 & -10.7 & 8.8 & 6.2 & 3.3 & -2.7 & $3510 \pm 20$ \\
\hline 41HY163 & $1(\mathrm{M})$ & -17.7 & -9.8 & 9.4 & 7.9 & 3.3 & -4.0 & $1300 \pm 20$ \\
\hline 41HY163 & $2(\mathrm{~F})$ & -17.9 & -11.0 & 8.8 & 6.9 & 3.3 & -2.8 & $1215 \pm 20$ \\
\hline 41HY163 & $3(\mathrm{~F})$ & -17.8 & -10.3 & 9.1 & 7.5 & 3.3 & -4.0 & $1305 \pm 20$ \\
\hline 41HY160 & $1(\mathrm{M})$ & -18.6 & -10.74 & 10.0 & 7.8 & 2.8 & -3.26 & $2015 \pm 20$ \\
\hline
\end{tabular}

When working with population-level samples, important insights can be gained into dietrelated behaviors according to regionally available resources, which may change over time with environment or across space by habitat. Reconstructing diet using carbon and nitrogen can be complicated, however, as several factors that have been discussed influence $\delta^{13} \mathrm{C}$ and $\delta^{15} \mathrm{~N}$. Because local food systems are based on highly variable factors specific to region, climate, proximity to coastal or riverine systems, and so forth, comparative analyses should be done on a local basis. Most useful for dietary reconstructions are reconstructions of local food webs and the isotopic signatures of different plant and animal resources that are found in that study area. Such models, built from isotopic measurements taken from locally occurring plant and animal resources, provide an interpretive framework for understanding the complex interactions between consumer behavior and access to resources, available foodstuffs, and the effect of trophic enrichment (i.e., isotopic enrichment or fractionation that occurs at increasing levels of the food chain) for some important species. Plotting the small set of six San Marcos burials on a generalized food web model for North America indicates that all but one shared a diet relatively similar to what would be expected of people living near a riverine environment (Figure 8-17).

Five of the six burials from this area seem to indicate use of the kinds of food resources associated with a riverine environment. Burial Number 1 from 41HY161, however, shows strong evidence for heavy consumption of marine foodstuffs. This female is identified on this basis as likely having come into the area from somewhere along the coast. Her oxygen isotope value (-2.5) is also the highest among this small sample, further identifying her as non-local to the area. We argue that these multiple lines of evidence, including not only sex but also $\delta^{13} \mathrm{C}_{\mathrm{COL}}$, $\delta^{13} \mathrm{C}_{\mathrm{AP}}, \delta^{15} \mathrm{~N}$, and $\delta^{18} \mathrm{O}$, provide perhaps the best available evidence for non-local origins and that 


\section{Chapter 8}

such data are needed before conclusions about in-migrations or the exchange of mates can be substantiated.

As discussed, different dietary behaviors are represented by different lines of isotopic evidence. The spacing or interval between $\delta^{13} \mathrm{C}_{\mathrm{AP}}$ and $\delta^{13} \mathrm{C}_{\mathrm{COL}}$ can help archaeologists understand differences in protein, specifically meat consumption among and within ancient populations. Changes of $\sim 7$ between $\delta^{13} \mathrm{C}_{\mathrm{AP}}$ and $\delta^{13} \mathrm{C}_{\mathrm{COL}}$ are expected in herbivore diets, while $\sim 5 \%$ characterizes omnivore diets and $\sim 3-4 \%$ is associated with carnivore diets. In cultural contexts in which meat is considered a luxury or high status food, measuring $\delta^{13} \mathrm{C}_{\mathrm{AP}}$ to $\delta^{13} \mathrm{C}_{\mathrm{COL}}$ spacing can help define differences in social rank that are partly based on access to different foods. Because these kinds of food-related value systems are culturally specific, comparisons are most meaningful within discrete populations rather than across large areas and involving many cultural traditions. For example, a cemetery population of 17 adult males and females from the Coleman Site, 41BX568 (Mauldin et al. 2013), contained 10 "mature" (older than 10

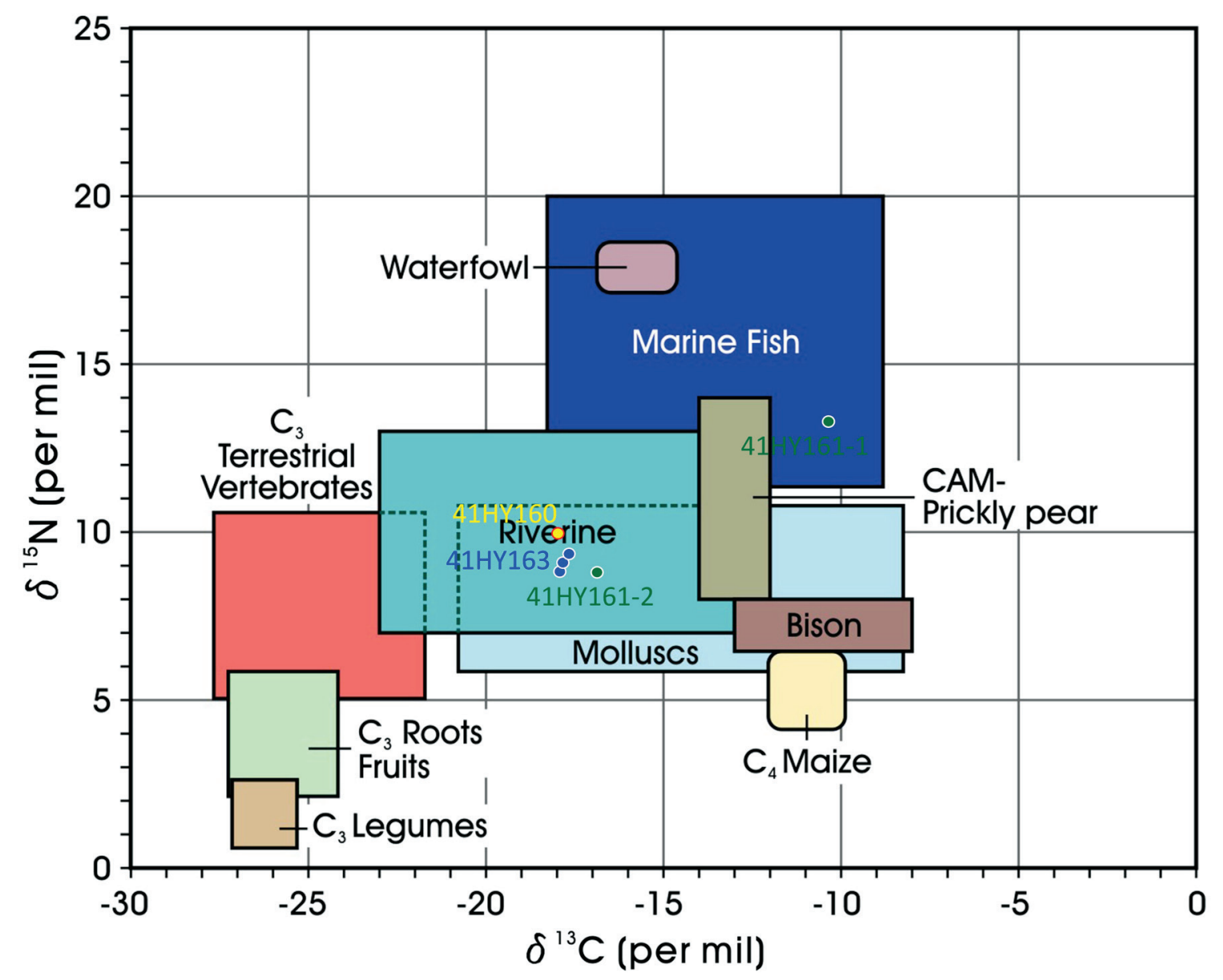

Figure 8-17. Stable carbon and nitrogen isotope values for six San Marcos burials, including the individual from the Ticket Kiosk excavation (in yellow) in relation to a generalized food web model (after Munoz et al. 2011: Figure 8-1). 
years of age) individuals, six males and four females, for whom apatite-collagen spacing could be calculated. Of these, the average spacing interval for males compared to females is 7.85 vs. 7.57 , suggesting that on average males consumed slightly more meat protein than did females in the same population. However, standard deviations with each of these small sex-based groups (0.878 for males vs. 1.024 for females) suggest greater food-related behavioral variation among females than males (see Mauldin et al. 2013 for these data). These comparisons are difficult to apply to the San Marcos burial population given its small size, but data in Table 8-6 show that the two males also maintain higher spacing, on average, than the two females (7.85 vs. 7.2). This simple comparison excludes the non-local female, whose low spacing interval, 2.5, is the result of her very low $\delta^{13} \mathrm{C}$ value. The Coleman Cemetery dates to the early Toyah period, while the San Marcos burials span approximately 3000 years, from ca. 500 to 3500 cal B.P. Although a larger sample is needed to support these conclusions, when taken together, these data suggest that males on average had greater access to meat-based protein than their female counterparts, at least at inland riverine and other terrestrial prehistoric sites in Central Texas. Additionally, it is suggested that females, as a group, display greater variation in food-related consumption behavior than their male counterparts. This was seemingly true for all time periods represented in the present data set.

An additional line of interpretation possible for the small San Marcos burial set involves using $\delta^{13} \mathrm{C}_{\mathrm{AP}}$ and $\delta^{13} \mathrm{C}_{\mathrm{COL}}$ in conjunction with the contextual information provided by regional food web models to understand total diet. Recent isotopic studies on prehistoric huntergatherer populations in and around Central Texas (Bement 1994; Hard and Katzenberg 2011; Mauldin et al. 2013; Munoz et al. 2011) that have produced the minimally comparable lines of data discussed here (including carbon from collagen and apatite as well as nitrogen but excluding oxygen) have begun to provide a general view of how prehistoric hunter-gatherer diets have changed through time. By using idealized pure $\mathrm{C} 3$ and $\mathrm{C} 4$ diets and also by incorporating sources of marine and non-marine protein, analysts can plot individual-level dietary histories by time in ways that show important general trends from one prehistoric period to the next. In particular, this includes distinguishing between C3 and C4 protein groups, as well as the ratio of $\mathrm{C} 3$ and $\mathrm{C} 4$ foods in the whole diet.

Data points representing each individual's $\delta^{13} \mathrm{C}_{\mathrm{AP}}$ and $\delta^{13} \mathrm{C}_{\mathrm{COL}}$ are plotted against regression lines indicating the protein groups (Kellner and Schoeninger 2007; Froehle et al. 2010). Together, Early, Middle, and Late Archaic and also Austin period burials show a clear trend of increasing reliance on C3 plants, including roots, geophytes, and mast such as pecan, mesquite, walnuts, and persimmons (Hard and Katzenberg 2011: Table 6) ( Figure 8-18). The Late Archaic San Marcos burial set, including the single individual from the Ticket Kiosk, falls neatly into this pattern. However, based on the Coleman cemetery population $(\mathrm{n}=11)$ from Bexar County and dating to the early Toyah period, this trend sharply reverses immediately following the Austin period. Toyah diets are generally more dispersed and closely mirror consumption patterns of the Early, Middle and Late Archaic. Importantly, no time period 


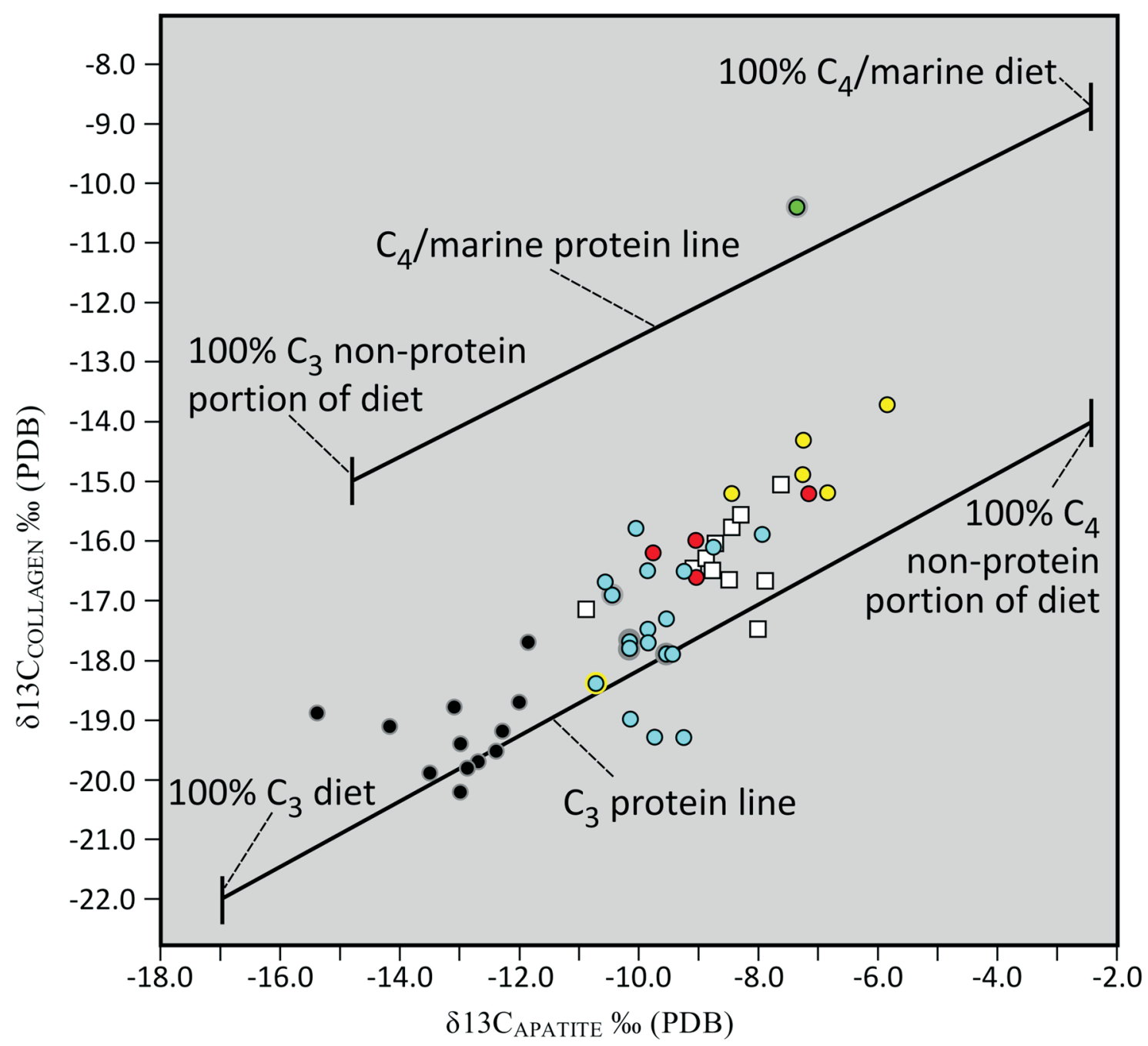

$\square$ Coleman site, early Toyah

- Austin period

- Late Archaic

- Middle Archaic o Early Archaic

Figure 8-18. Prehistoric burial isotope data from Central Texas plotted against protein group regression lines created from controlled dietary studies reported in Froehle et al. (2010). Redrawn from Mauldin et al. (2013: Figures 2 and 6).

seems strongly influenced by $\mathrm{C} 4$ protein, which raises questions regarding the degree to which this method of reconstructing total diet accurately accommodates all protein intake. Parts of the Late Archaic and much of the Toyah period are thought to have been characterized by exploitation of bison, yet no heavy reliance on bison-derived protein seems to be indicated in Figure 8-18. 
In an attempt to more accurately reflect total diet, Froehle et al. (2012; also Somerville et al. 2013) have created a multivariate model of isotopic variability that allows them to plot three variables, $\delta^{13} \mathrm{C}_{\mathrm{AP}}, \delta^{13} \mathrm{C}_{\mathrm{COL}}$, and $\delta^{15} \mathrm{~N}_{\mathrm{COL}}$ rather than simply $\delta^{13} \mathrm{C}_{\mathrm{AP}}$ and $\delta^{13} \mathrm{C}_{\mathrm{COL}}$. Through $k$-means cluster analyses on archaeological populations from diverse areas around the world and whose diets were relatively well known, Froehle et al. (2012) identified five discrete dietary subgroups or "clusters," each of which correlates with diets of certain makeup (Table 8-7). These three isotopic variables were seen to have significant influence on the clusters that were defined, and two discriminant functions were found to account for 98.8 percent of the overall variation recorded within this "training sample." Function 1 (F1) accounts for most of the isotopic variation related to carbon, while Function 2 (F2) was found to account for most of the variation relating to nitrogen intake. These functions are calculated as:

$$
\begin{aligned}
& \text { Carbon: } \mathrm{F} 1=\left(0.322^{*} \delta^{13} \mathrm{C}_{\mathrm{AP}}\right)+\left(0.727^{*} \delta^{13} \mathrm{C}_{\mathrm{COL}}\right)+\left(0.219 * \delta^{15} \mathrm{~N}_{\mathrm{COL}}\right)+9.354 \\
& \text { Nitrogen: } \mathrm{F} 2=\left(-0.393^{*} \delta^{13} \mathrm{C}_{\mathrm{AP}}\right)+\left(0.133^{*} \delta^{13} \mathrm{C}_{\mathrm{COL}}\right)+\left(0.622^{*} \delta^{15} \mathrm{~N}_{\mathrm{COL}}\right)-8.703
\end{aligned}
$$

As noted, this approach is intended to provide resolution with respect to protein-related ambiguities and is intended to help clarify sources of C3 vs. C4 protein as well as terrestrial vs. marine protein (Froehle et al. 2012:353). It is used here as a means of evaluating whether additional understanding of prehistoric diets can be gained by use of isotopic data.

Table 8-7. Cluster Diets Defined through $k$-means Cluster Analysis of Published Archaeological Data Regarding Dietary Contributions Measured by Isotopic Variation (from Froehle et al. 2012: Table 1)

\begin{tabular}{ccc}
\hline Cluster & Total diet & Protein Source \\
\hline 1 & $100 \% \mathrm{C} 3$ & $100 \% \mathrm{C} 3$ \\
2 & $70 \% \mathrm{C} 4$ & $>50 \% \mathrm{C} 4$ \\
3 & $50 \% \mathrm{C} 3$ & High marine protein \\
4 & $70 \% \mathrm{C} 3$ & $\geq 65 \% \mathrm{C} 3$ \\
5 & $70 \% \mathrm{C} 4$ & $\geq 65 \% \mathrm{C} 3$ \\
\hline
\end{tabular}

By including nitrogen, greater resolution may be possible in terms of understanding sources of protein intake, as protein influences the $\delta^{15} \mathrm{~N}$ values in human skeletal material. The overall understanding of nitrogen isotopic variation in animals is underdeveloped in relation to carbon. As noted, nitrogen enrichment increases with each trophic level. However, some animals, including obligate drinkers, are also affected by the condition of ambient water supplies which respond closely to climate conditions. Isotopic analyses of archaeological bison remains from Spring Lake, for example, document average $\delta^{15} \mathrm{~N}$ values that change markedly by time period ( Figure 8-19). In contrast, a survey of $\delta^{15} \mathrm{~N}$ values from 60 modern white-tailed deer from North America shows an average of $4.3 \pm 2.0 \%$ (Cormie and Schwartz 


\section{Chapter 8}

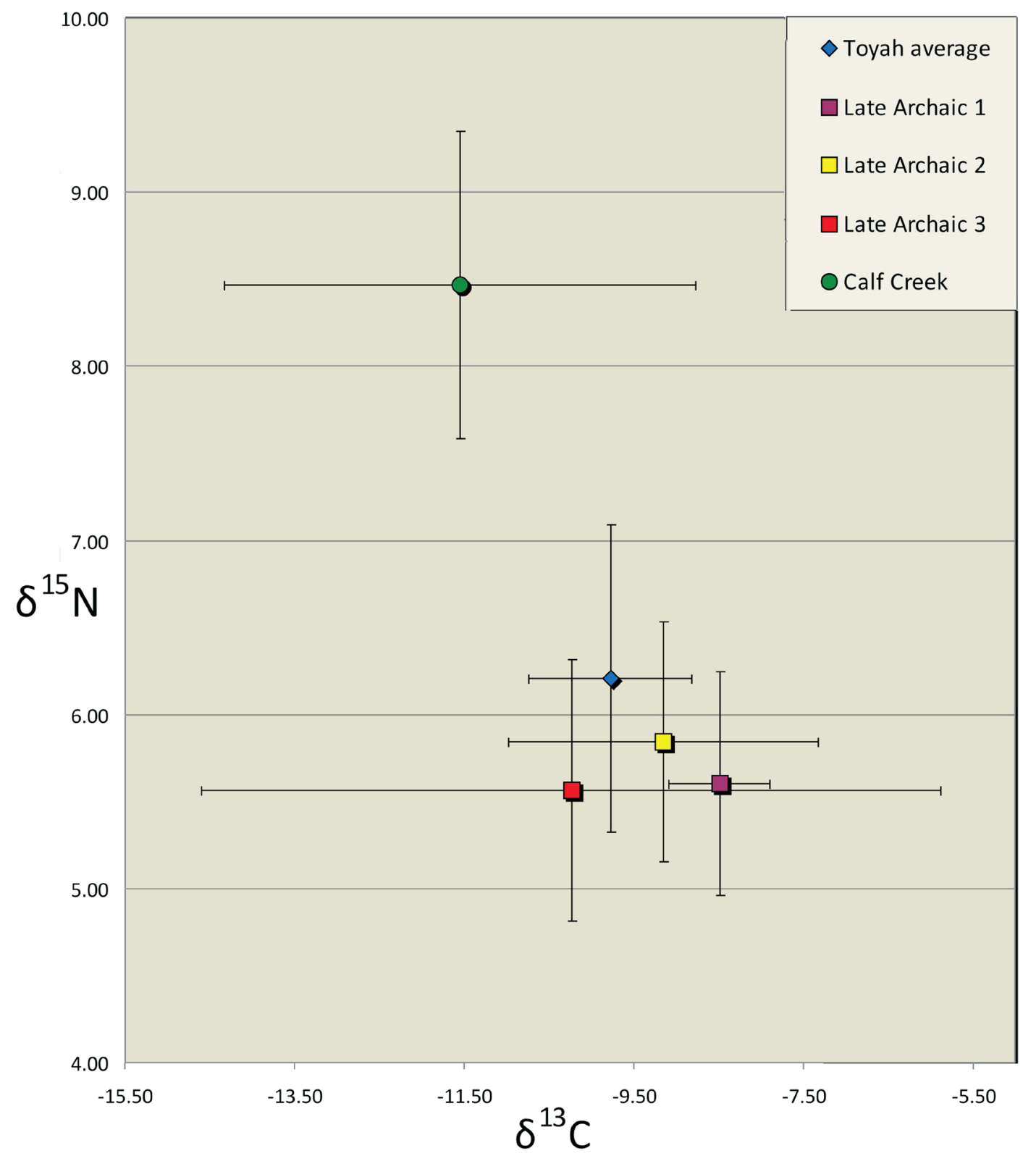

Figure 8-19. Average isotopic variation with standard deviations for archaeological bison remains from Spring Lake and nearby sites by time period (Lohse et al. 2012).

1994). Based solely on differences between nitrogen values for deer versus bison, one might expect the consumption of at least some bison to be indicated in the isotopic record by slight increases in $\delta^{15} \mathrm{~N}$ values in human skeletal remains, in addition to enrichment in $\delta^{13} \mathrm{C}_{\mathrm{COL}}$. However, yet another interpretive challenge with using nitrogen to reconstruct protein consumption is that some animals, especially deer, show marked intra-species variability in 
terms of response to water stress (Cormie and Schwarcz 1996). Approximately 25 percent of white-tailed deer populations respond to stress not by concentrating uric acid but rather by modifying their browsing behavior to include a greater abundance of $\mathrm{C} 4$ plants. The result is that the consumption of deer, in particular, presents problems for understanding the consumption of protein because their behavioral changes during periods of water stress result in high intra-species variation in $\delta^{15} \mathrm{~N}$. Given these issues, any analytical approach that allows archaeologists to isolate small dietary changes in the isotopic record, such as the addition of moderate amounts of bison to an otherwise broad-spectrum diet should be considered for use.

The number of prehistoric burials from greater Central Texas for which all necessary data necessary for a multivariate isotopic analysis exist is limited to only 53 individuals. All of these remains except for the individual from the Ticket Kiosk have been previously reported, and are summarized by Mauldin et al. (2013). Use of the multivariate isotope analytical technique (Figure 8-20) shows the same general kind and degree of dietary distinction by time period as seen using the "simple" bivariate plot based on $\delta^{13} \mathrm{C}_{\mathrm{AP}}$ and $\delta^{13} \mathrm{C}_{\mathrm{COL}}$ (see Figure 8-18). Time periods are defined, with some overlap, by a gradual decrease in Function 1 (carbon) and an increase in Function 2 (nitrogen) from Early Archaic to Austin, with Toyah returning to approximately the same general range of values as seen in the Early Archaic sample. The Austin-period population falls largely outside the dietary clusters defined by Froehle et al. (2012). Based on the characteristics of clusters 1 and 4, Austin-period diets in the region appear to have consisted of 70-100 percent C3 total diet and 65-100 percent C3-derived protein.

Two important exceptions are Toyah and Toyah/Protohistoric "outliers" that have diets in or near Cluster 2 (70 percent $\mathrm{C} 4$ total diet, > 50 percent $\mathrm{C} 4$ protein). One of these is the same female identified as non-local from Spring Lake; no sex data are available for the other (Cargill 1996). Interestingly, time periods during which bison were presumably present on the landscape, including Toyah, Early Archaic, and precise intervals of the Late Archaic (Dillehay 1974; Lohse et al. 2012) are not strongly differentiated by Function 2 (nitrogen) as one might expect if changes in the consumption of terrestrial C4 fauna (bison) were marked enough to over-determine other dietary sources of isotopic variation. Rather, based on this model, it appears that bison, when and if consumed, is difficult to distinguish based on isotopic study at this temporal resolution (see earlier discussion of turnover rates for bone collagen and apatite). In cases, such as the Spring Lake burial set and that of the Coleman Site, for which precise, reliable dates are available, future analyses should seek to understand what variation may have been present within the gross temporal categories ("Late Archaic" or "Toyah") that are used here. 


\section{Chapter 8}

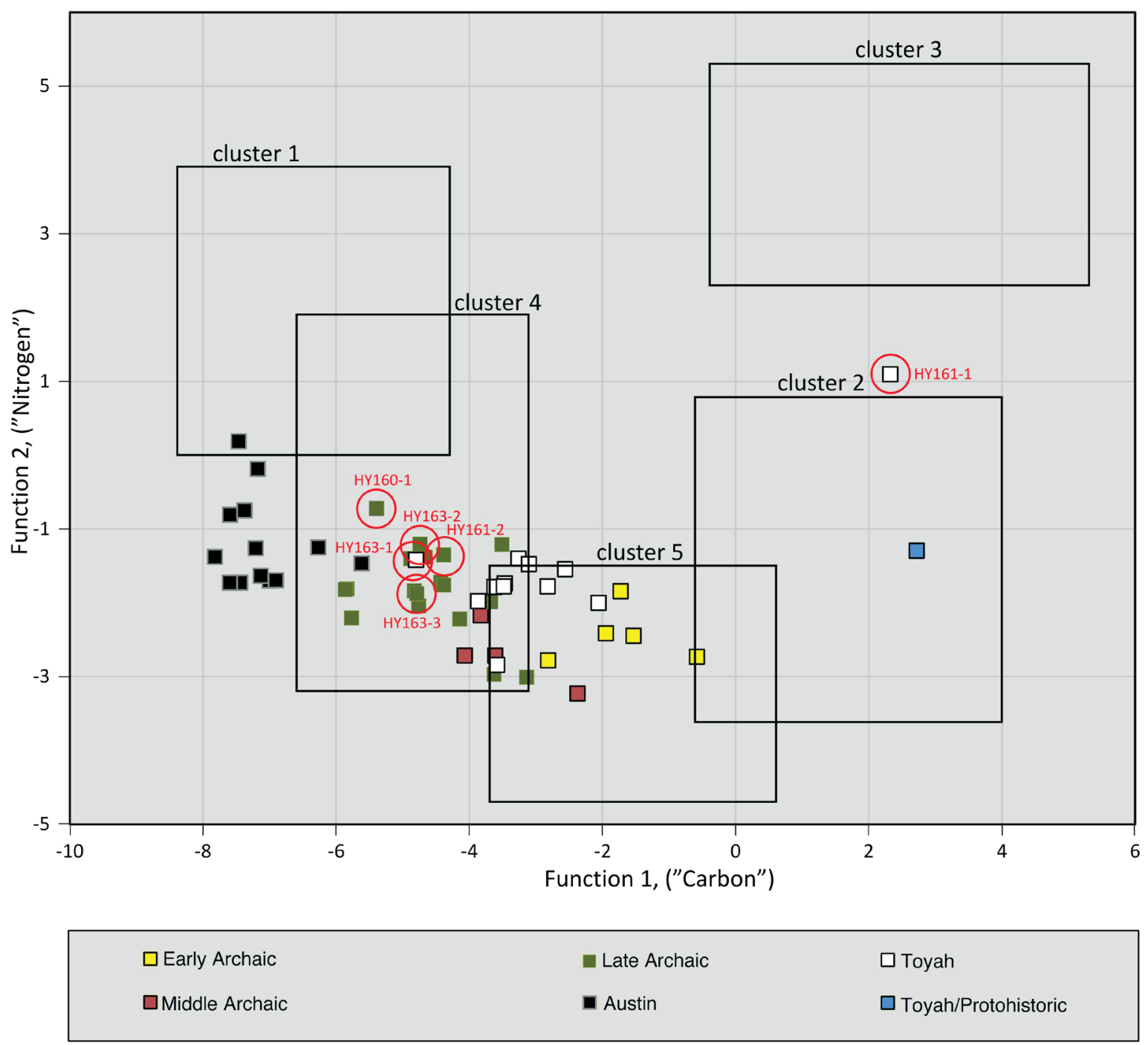

Figure 8-20. Discriminant function temporal values from prehistoric burial data from greater Central Texas plotted against dietary clusters. Spring Lake burial data are highlighted. 


\section{Chapter 9 Conclusions and Recommendations}

by Jon C. Lohse

Archaeological excavations and monitoring were conducted at the new TxSt Ticket Kiosk at Aquarena Springs in order to mitigate important information loss resulting from this construction project. The construction site lies within the boundaries of State Antiquities Landmark 41HY160, and deposits here extend as much as or more than $20 \mathrm{ft}$ below the modern ground surface, representing all time periods that define the local and regional cultural chronology. Controlled excavations were restricted to a single $1 \times 2 \mathrm{~m}$ unit excavated to a depth of $3 \mathrm{~m}$. This unit included approximately half of the area of disturbance resulting from the installation of a lift station to provide head pressure to nearby restroom facilities. Additional archaeological investigations including monitoring a series of smaller trenches and disturbances associated with the installation of various utilities to service the new building. One trench exposed a human burial, explained in detail in Chapter 8.

This work contributes to the overall understanding of the Spring Lake site complex and to Central Texas prehistory in numerous ways. As discussed in earlier chapters, the primary contribution involves adding a considerable amount of information to the existing body of information about the Calf Creek horizon. This important horizon (Thurmond and Wyckoff 1999) has been defined across most of Oklahoma (Wyckoff 1994, 1995), areas of Texas where Plains-type grassland habitats were present during this period (Collins 1995), and parts of Kansas and Missouri. Within Texas, Calf Creek-period point types include Andice (Prewitt 1983) and Bell (Sorrow et al. 1967). The extent of these two point types across much of the state (Collins et al. 2011: Figure 8; Prewitt 1995) reveals that this horizon was widespread. Previous research, however, has left the timing and environmental nature of the period imprecisely defined. Additionally, with the exception of a few localities where Bell/Andice material has been reported in profusion, including the Gault site (Prewitt 1983; see Collins 1994) and in Victoria County (Bill Birmingham, personal communication to Jon Lohse, 2012), many finds from this period seem limited to surface collections (e.g., Calame et al. 2002; 


\section{Chapter 9}

Chandler and Kumpe 1993), are single artifacts without context or secure provenience (Yelacic et al. 2008a: Figure 4-84), or occur in compressed or highly mixed components with other timediagnostic material and poor geologic resolution (e.g., Unit IIIb at Wilson-Leonard, 41WM235 [Stafford 1998] and Occupation Zone 2 at Gatlin, 41KR261 [Houk et al. 2008]). Intact, wellstratified Calf Creek components with the potential to contain evidence for multiple lines of technological, chronometric, and subsistence research into this interval are rare. The Landslide Site, 41BL85 (Sorrow et al. 1967), excavated in the Stillhouse Hollow Reservoir was one such site, as apparently was the Cervenka Site, 41WM267 (Peter et al. 1982), excavated in the San Gabriel Reservoir area. Based on the preliminary information available from Spring Lake, 41HY160 has potential to be among the richest, best temporally resolved Calf Creek-period sites yet recorded by archaeologists.

\section{What We Know and Wish We Knew about Calf Creek}

The Calf Creek horizon is noteworthy for the close association between Middle Holocene bison exploitation and technologically distinctive, triangular-shaped dart points with deep characteristic basal notching. Direct evidence for the use of Calf Creek points in hunting bison was reported from Oklahoma (Bement et al. 2005), where a juvenile bison skull with a Calf Creek point embedded in the base of one of the horns was uncovered in a stream bed. Bison remains are commonly reported from multicomponent sites where Calf Creek material is present, and Spring Lake follows this general rule (see discussion of faunal remains in Chapter 6). This period of bison presence precedes the mid-Holocene Altithermal event of peak aridity and, according to some models, temperatures. In Central Texas, this occurs at ca. 4200-2800 cal B.P., during the Edwards Interval (see Chapter 2). Because of these conditions, Calf Creek material from Central Texas has proven difficult to date precisely as a result of sediment loss and component mixing caused by landscape erosion and deflation.

Our work at the Ticket Kiosk provides a highly resolved temporal model for the Calf Creek horizon. The sequence of dates produced by the project (see Table 5-1) complements others derived from bison remains from nearby sites (Lohse et al. 2012) and suggests that the Calf Creek interval may have been no more than $\sim 250$ years in duration, ca. 5750-6000 cal B.P. This age estimate puts Calf Creek at the very end of the regional Early Archaic time period (Lohse et al. 2014) and is based on several $(n=12)$ of high-precision XAD-purified AMS dates on bison remains (see Figure 2-6). The Calf Creek component reported here is bracketed by two non-bison XAD bone dates from just above and just below the bison-bearing zone at the Ticket Kiosk excavation. Future research should continue to refine this age estimate by processing more dates from this sequence, including the submission of series of assays on taxonomically consistent (e.g., white-tailed deer, artiodactyl, etc.) non-bison remains that occur above, within, and below the Calf Creek deposit. In addition, complementary dating efforts at other sites that follow the same protocols outlined in the present study would add to the overall picture of Calf Creek as it occurs in Texas. 
Two aspects of an improved understanding of Calf Creek chronology would be distinguishing insofar as possible between the appearance of Bell and Andice points on the archaeological landscape and relating Calf Creek point production technology to its immediate antecedents. Presently, it is not known whether Bell and Andice occupy the same exact time period, or whether one slightly predates the other. Achieving this degree of temporal precision will require that archaeologists dedicate sufficient resources to constructing high resolution chronologies at sites where one or the other type seems to dominate the assemblage. As defined, Calf Creek technology is characterized by distinctive basally notched points. These points seem to have fallen out of favor very quickly, and were replaced in archaeological sequences by unnotched Early Triangular points. However, notching is present on both Bandy and Merrell points, which date immediately prior to Calf Creek (Figure 9-1). Previous

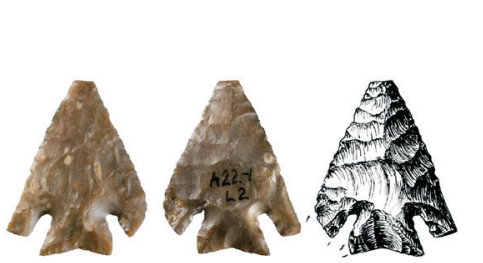

A
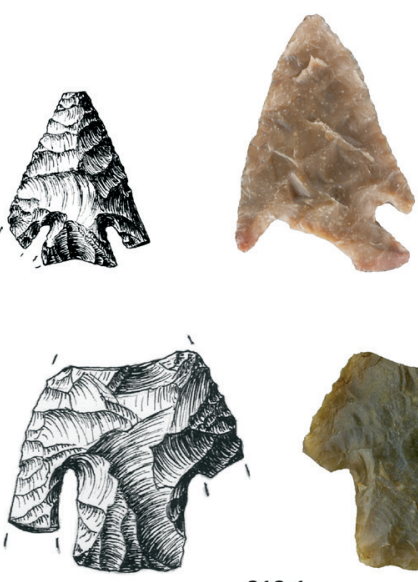

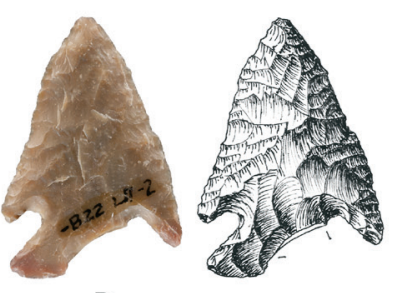

B

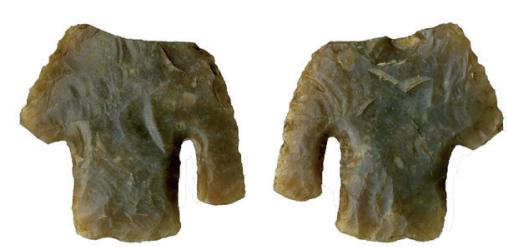

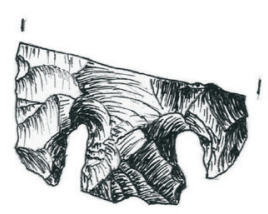
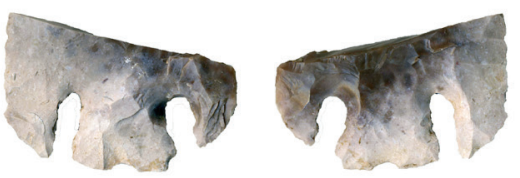

$430-1$

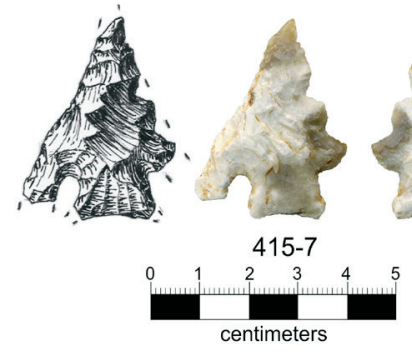

Figure 9-1. Bandy (A) and Merrell (B) points from Spring Lake compared with Calf Creek (Bell) points discussed in this report. All three types show characteristic corner (Bandy and Merrell) and basal (Bell) notching. Bandy and Merrell types immediately precede Bell and Andice in regional chronologies, and the knapping debris associated with these types, notching flakes in particular, may be difficult to distinguish. 


\section{Chapter 9}

explanations for the appearance of Calf Creek cultural patterns in the study area include bison hunters pursuing herds from the north and northeast during this particular climatic interval (see Collins 1995:384; Wyckoff 1995). However, demonstrating any kind of technological continuity with previous cultural traditions would help archaeologists better understand the nature of Calf Creek adaptations as they occur in Central Texas.

Related to the issue of chronological precision is a better understanding of technological strategies implemented for the manufacture and production of Calf Creek (Bell and Andice) points and other toolkit components. Relatively few studies regarding technological approaches to characteristic Bell and Andice points have been undertaken (Weber 1994), and specific manufacturing strategies that can help separate these two types remain poorly understood. Can different strategies for producing these types be defined that may help archaeologists better distinguish between Calf Creek populations? Pure Bell or Andice components seem to be exceedingly scarce on the landscape, a limitation which would seem to pose a challenge to such studies. But where they do occur, such assemblages would be outstanding candidates for providing the kinds of technological insight needed to better understand this cultural pattern.

In addition to technology, findings reported here point to some issues regarding diet and subsistence that indicate significant trends or adaptation shifts that may characterize Calf Creek, at least in Central Texas. With respect to subsistence practices and the effect of bison exploitation on Archaic diets, our findings here seem to show relatively little changes to overall diet with the inclusion of bison. The Ticket Kiosk sample is probably too small to substantiate detailed conclusions, although it does show a slight yet distinct increase in faunal assemblage richness (the number of taxons present) from Calf Creek to later times (see Table 6-1). This increase from an average of 8 to 9 taxons during Calf Creek times to 12 to 13 taxons in the period that immediately follows may be significant; it appears to indicate a more limited diet, as fewer species were taken during the period when bison were available on the terminal Early Archaic landscape. However, based on the fauna that are present, which include whitetailed deer, turtles, and small mammals such as rabbits, local diets still resemble the kinds of broad-spectrum diets that characterize most Archaic assemblages. Rather than representing a shift away from smaller- and medium-bodied game, this small sample suggests that Calf Creek peoples simply added bison to their diets and compensated by lessening their reliance on only a few other resources in response. For example, no fish were observed in this part of the Spring Lake deposit, although systematic recovery methods specifically targeting these small remains were not implemented during this project. Future analyses on this issue should target relatively "pure" (unmixed) Calf Creek components such as this one, and apply fine-mesh recovery techniques allowing for the capture of small faunal remains. Additionally, a much larger sample size than the one reported here is needed in order to support any conclusions that may be reached concerning dietary adaptations during Calf Creek times. Considering the mobile nature of prehistoric hunter-gatherer populations, it would be ideal if such studies could be conducted at multiple well-preserved sites located in diverse environmental settings 
that offer access to many different suites of subsistence resources.

A final contribution of this project to the overall understanding of Calf Creek involves climate and site reconstruction. Our stratigraphic analysis clearly shows that the Calf Creek component here postdates the development and formation of the buried soil at just over 170 cmbd indicated in Figure 4-1. Indeed, our model of sedimentation rates for the site indicate rapid, sustained deposition beginning well before Calf Creek times and culminating around $4200 \mathrm{cal}$ B.P. (see Figure 2-3). This sequence indicates that starting before ca. $6000 \mathrm{cal}$ B.P., archaeologists can expect to find and should seek out stable surfaces associated with archaeological remains that can be dated and that may contain well-preserved remains stemming from subsistence and technological practices. Such surfaces, where they remain intact, as at Spring Lake, may be deeply buried but well stratified. How do archaeologists understand climatic conditions that favor these kinds of depositional environments and that support or give rise to the appearance of open grassland-type habitats that are associated with bison? Temperature and precipitation reconstructions based on phytoliths from Hall's Cave (see Figure 2-5) suggest high rates of precipitation just before Calf Creek followed by a period of relatively intensive drought. This sequence, however, lacks fine temporal precision, and other better dated records would improve our understanding of environmental change across the Middle Holocene.

\section{Summary}

Excavations in this part of $41 \mathrm{HY} 160$ show clearly that the Spring Lake site contains a rich and sometimes highly resolved record of prehistoric occupation associated with important contextualizing environmental data. Although the analytical sample recovered in this phase of work is limited in many respects, it indicates that numerous significant issues that define or characterize Central Texas regional prehistory can be understood through controlled, scientific methodologies. Foremost among these is that high-resolution cultural chronologies can be compiled given commitment of sufficient resources and use of appropriate analytical techniques. Archaeologists working in Central Texas often lack a clear and detailed understanding of many Archaic-period sequences, developments, and adaptations. Much of this poor understanding is the result of compressed geologic sequences and insufficient attention to absolute dating standards, circumstances that are in part overcome at Spring Lake.

This report contributes to the growing body of data about the cultural resources at Spring Lake. It is recommended that future archaeological studies at this site, whether initiated through compliance requirements of construction or development projects or carried out with grant support, should consider the potential for this rich site to serve as a baseline of sorts for the construction of local as well as regional models that can be applied more broadly in other parts of the Central Texas region. Future studies would be well served to build on advances made by this and other previous studies while seeking to expand our total awareness of Spring Lake and the long-term sequence of human occupation it contains. 



\begin{tabular}{|c|c|c|c|c|c|c|c|c|c|c|c|c|c|c|c|c|}
\hline & 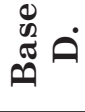 & & 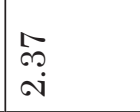 & & $\begin{array}{l}\infty \\
\infty \\
0 \\
0\end{array}$ & $\begin{array}{l}+ \\
\infty \\
0 \\
0\end{array}$ & $\begin{array}{l}H \\
\text { on } \\
0 \\
0\end{array}$ & $\begin{array}{l}\vec{H} \\
\stackrel{+}{r}\end{array}$ & $\begin{array}{l}\vec{H} \\
\stackrel{1}{\circ}\end{array}$ & 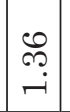 & $\begin{array}{l}\overrightarrow{-} \\
\ddot{\infty} \\
\infty\end{array}$ & 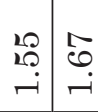 & & & & \\
\hline & 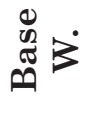 & & 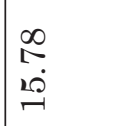 & $\begin{array}{l}0 \\
\stackrel{0}{+} \\
\stackrel{1}{+} \\
\end{array}$ & $\begin{array}{l}\infty \\
\infty \\
- \\
- \\
-\end{array}$ & $\begin{array}{l}-1 \\
0 \\
0 \\
-1\end{array}$ & 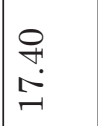 & 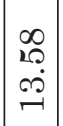 & & $\mid \begin{array}{c}-\vec{b} \\
\text { àj } \\
\text { ลे }\end{array}$ & & 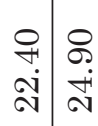 & $\begin{array}{l}\stackrel{8}{0} \\
\stackrel{0}{9} \\
-1\end{array}$ & 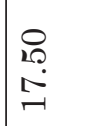 & & $\begin{array}{l}0 \\
\stackrel{0}{N} \\
\stackrel{\sim}{N}\end{array}$ \\
\hline$\stackrel{\mathscr{\Xi}}{\Xi}$ & 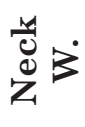 & \begin{tabular}{|c|}
0 \\
0 \\
0 \\
0 \\
-1
\end{tabular} & $\begin{array}{l}8 \\
80 \\
10 \\
11\end{array}$ & $\begin{array}{l}\infty \\
0 \\
\infty \\
-1 \\
-1\end{array}$ & 足 & $\begin{array}{l}\stackrel{+}{\mathrm{N}} \\
\stackrel{+}{+}\end{array}$ & $\begin{array}{l}\vec{H} \\
\stackrel{H}{+} \\
\dot{H}\end{array}$ & 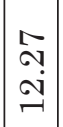 & 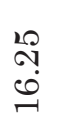 & $\begin{array}{l}\mathscr{2} \\
\mathscr{S} \\
\mathfrak{1} \\
\mathfrak{-}\end{array}$ & 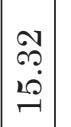 & 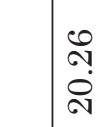 & 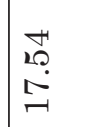 & $\begin{array}{l}\stackrel{+}{~} \\
\stackrel{2}{\sim} \\
\stackrel{\sim}{\sim}\end{array}$ & $\begin{array}{c}+ \\
\stackrel{+}{+} \\
\infty \\
-1 \\
-1\end{array}$ & $\begin{array}{l}\infty \\
\sim \\
\sim \\
\sim \\
\infty \\
\infty\end{array}$ \\
\hline $\begin{array}{c}0 \\
0 \\
0 \\
0 \\
0 \\
0 \\
0 \\
0\end{array}$ & 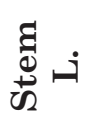 & & $\begin{array}{l}\infty \\
\infty \\
\stackrel{+}{+} \\
+\end{array}$ & $\begin{array}{l}20 \\
0 \\
0 \\
-1\end{array}$ & $\begin{array}{l}5 \\
\alpha \\
20 \\
\end{array}$ & $\begin{array}{l}-\sigma \\
-1 \\
-1\end{array}$ & $\begin{array}{l}-\infty \\
\infty \\
\infty \\
\sim \\
-1\end{array}$ & 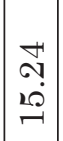 & 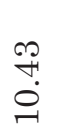 & 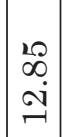 & $\begin{array}{c}1 \\
10 \\
0 \\
0 \\
-1\end{array}$ & $\begin{array}{l}0 \\
\stackrel{-}{\circ} \\
\stackrel{-}{\sim} \\
\sim\end{array}$ & $\begin{array}{l}\stackrel{\infty}{\infty} \\
\stackrel{\infty}{\sim} \\
\end{array}$ & $\begin{array}{l}\infty \\
\infty \\
\stackrel{+}{+} \\
\stackrel{+}{N}\end{array}$ & \begin{tabular}{l}
0 \\
0 \\
0 \\
0 \\
\multirow{N}{*}{}
\end{tabular} & 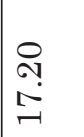 \\
\hline 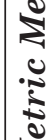 & $\begin{array}{l}\text { क्रि } \\
\text { 菅 }\end{array}$ & 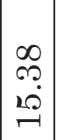 & هి & $\mid \begin{array}{l}10 \\
1\end{array}$ & 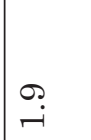 & $\stackrel{+}{+}$ & $\stackrel{\infty}{\infty}$ & $\begin{array}{c}0 \\
0\end{array}$ & $\begin{array}{l}\infty \\
0 \\
0\end{array}$ & $\left|\begin{array}{c}\infty \\
\stackrel{v}{o}\end{array}\right|$ & $\begin{array}{c}-1 \\
0\end{array}$ & 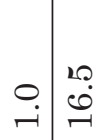 & $\begin{array}{l}0 \\
\stackrel{1}{*} \\
\stackrel{1}{-}\end{array}$ & 10. & 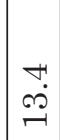 & in \\
\hline$\vec{z}$ & $\sum_{i}^{\stackrel{\leftrightarrow}{*}} \dot{3}$ & & $\begin{array}{l}\infty \\
\infty \\
\infty \\
\infty \\
-1 \\
1\end{array}$ & 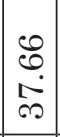 & & $\begin{array}{l}\stackrel{s}{a} \\
\infty \\
\infty \\
\infty\end{array}$ & $\begin{array}{l}0 \\
20 \\
00 \\
0 \\
\end{array}$ & $\left|\begin{array}{l}\Re \\
\stackrel{2}{\sim} \\
\stackrel{\sim}{N}\end{array}\right|$ & 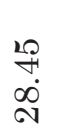 & & $\begin{array}{l}\stackrel{\rho}{+} \\
+ \\
\dot{0} \\
\infty\end{array}$ & $\begin{array}{l}10 \\
10 \\
\infty \\
\infty\end{array}$ & $\begin{array}{l}\stackrel{8}{0} \\
\infty \\
\stackrel{8}{\circ}\end{array}$ & 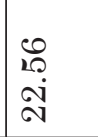 & $\mid \begin{array}{l}\vec{\sim} \\
\vec{s} \\
\vec{\Delta}\end{array}$ & $\begin{array}{l}\infty \\
-1 \\
\infty \\
\infty \\
\infty\end{array}$ \\
\hline & $\sum^{\stackrel{\star}{*}}$ & & 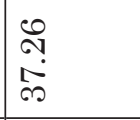 & & $\begin{array}{l}\text { ลิ } \\
\text { ลิ } \\
\text { ชิ }\end{array}$ & & \begin{tabular}{|l|}
10 \\
60 \\
60 \\
10 \\
\end{tabular} & \begin{tabular}{|c|}
0 \\
$\stackrel{1}{-}$ \\
$\stackrel{+}{+}$ \\
\end{tabular} & $\begin{array}{l}0 \\
\text { ov } \\
10 \\
\forall\end{array}$ & & & & $\mid \begin{array}{l}\infty \\
\stackrel{+}{+} \\
\stackrel{1}{1}\end{array}$ & 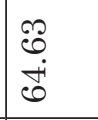 & & \\
\hline & $\dot{\varepsilon}$ & 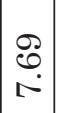 & 至 & $\mid \begin{array}{c}0 \\
10 \\
10 \\
10\end{array}$ & 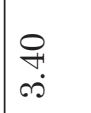 & $\begin{array}{l}2 \\
10 \\
10\end{array}$ & $\begin{array}{l}\hat{\sim} \\
\infty \\
\infty\end{array}$ & $\left|\begin{array}{l}2 \\
\infty \\
0 \\
0\end{array}\right|$ & ஸิ & $\left|\begin{array}{l}+1 \\
10 \\
0\end{array}\right|$ & $\begin{array}{l}1 \\
N \\
0 \\
0\end{array}$ & 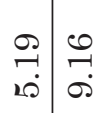 & 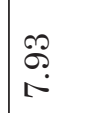 & $\begin{array}{l}\vec{b} \\
- \\
- \\
-\end{array}$ & $\begin{array}{l}\widehat{\omega} \\
\infty \\
\sigma \\
\sigma\end{array}$ & $\begin{array}{l}\stackrel{\circ}{\text { s }} \\
\text { ov } \\
\sim\end{array}$ \\
\hline & 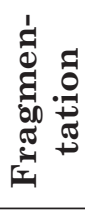 & 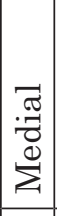 & 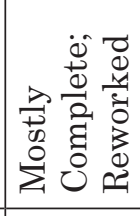 & 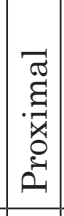 & 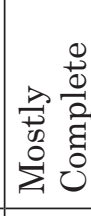 & 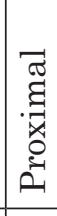 & 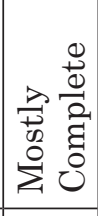 & $\mid \begin{array}{l}0 \\
0 \\
0 \\
0 \\
0 \\
a \\
0 \\
0\end{array}$ & 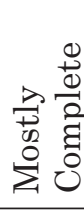 & 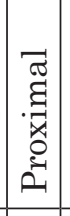 & 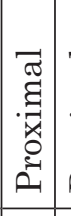 & 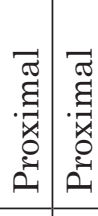 & 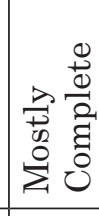 & 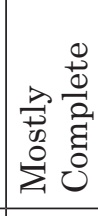 & 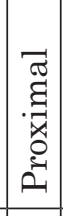 & 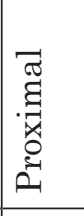 \\
\hline 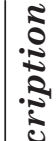 & $\begin{array}{l}\dot{0} \\
\dot{0} \\
\dot{2} \\
\dot{2}\end{array}$ & \begin{tabular}{l}
+ \\
\multirow{1}{1}{} \\
10 \\
10 \\
10
\end{tabular} & 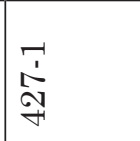 & 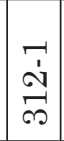 & $\begin{array}{l}5 \\
\stackrel{1}{1} \\
\text { H }\end{array}$ & 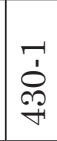 & 롱 & $\left|\begin{array}{c}0 \\
1 \\
1 \\
\hdashline \\
+ \\
\forall\end{array}\right|$ & $\begin{array}{l}\infty \\
\infty \\
\infty \\
\infty\end{array}$ & $\begin{array}{l}\overrightarrow{1} \\
\dot{2} \\
\dot{\infty}\end{array}$ & 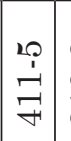 & 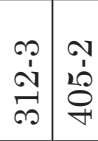 & 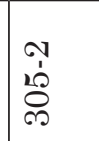 & 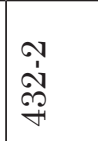 & $\begin{array}{l}\vec{r} \\
\infty \\
\infty \\
\infty \\
+\end{array}$ & $\begin{array}{l}+1 \\
\text { g } \\
\text { Oे }\end{array}$ \\
\hline 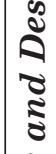 & $\stackrel{\circlearrowright}{2}$ & 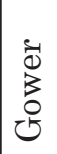 & & $\bar{\nabla}$ & & & $\begin{array}{l}\frac{0}{0} \\
\frac{\pi}{\pi} \\
\vec{b} \\
\end{array}$ & & 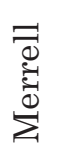 & & & 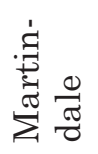 & 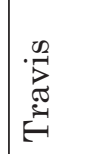 & & & 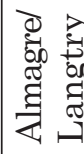 \\
\hline 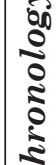 & 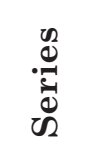 & 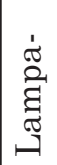 & & $\dot{~}$ & & & 兄 & & $\frac{\pi}{z}$ & & & $\frac{\pi}{Z}$ & $\mid \begin{array}{l}0 \\
0 \\
0 \\
0 \\
0\end{array}$ & & & \\
\hline & 胥 & 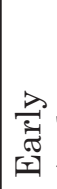 & 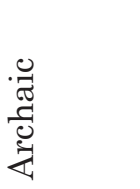 & & & & & & & & & & 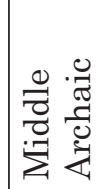 & & & \\
\hline
\end{tabular}




\section{Appendix A}

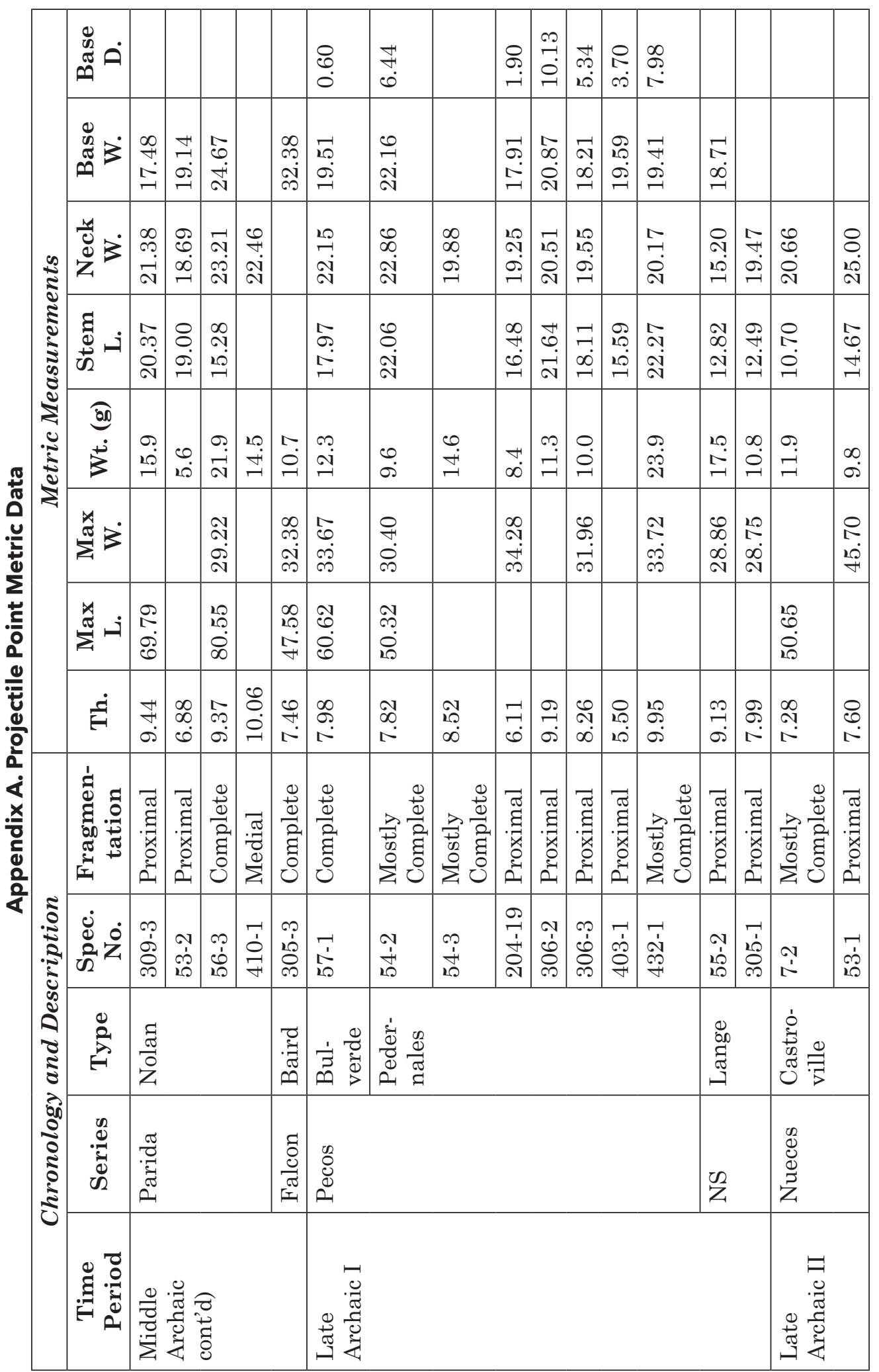




\begin{tabular}{|c|c|c|c|c|c|c|c|c|c|c|}
\hline & 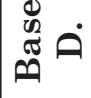 & & & & 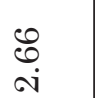 & & 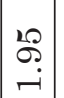 & & & \\
\hline & $\mathbb{E}_{\oplus}^{0}$ & 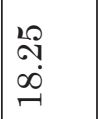 & $\begin{array}{l}\vec{F} \\
\stackrel{ت}{-}\end{array}$ & 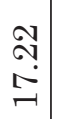 & & 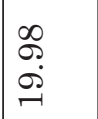 & $\begin{array}{l}9 \\
i \\
0 \\
0 \\
-1\end{array}$ & & $\begin{array}{l}\stackrel{\Omega}{\perp} \\
-i\end{array}$ & \\
\hline$\underset{\mathfrak{S}}{\stackrel{\infty}{\Xi}}$ & $\frac{\pi}{0}$ & $\begin{array}{l}\stackrel{N}{\sim} \\
\stackrel{-}{\sim}\end{array}$ & $\begin{array}{l}\vec{m} \\
\infty \\
\infty\end{array}$ & $\begin{array}{l}\stackrel{0}{ } \\
\stackrel{+}{+} \\
\stackrel{\sim}{\sim}\end{array}$ & 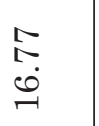 & 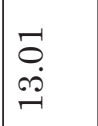 & 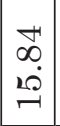 & $\begin{array}{l}\infty \\
\infty \\
10\end{array}$ & $\begin{array}{l}0 \\
10 \\
10\end{array}$ & $\begin{array}{l}\stackrel{+}{N} \\
10\end{array}$ \\
\hline $\mid$ & ن & $\begin{array}{l}\vec{H} \\
\stackrel{2}{a} \\
\sigma\end{array}$ & $\begin{array}{c}\stackrel{+}{-} \\
\stackrel{0}{0}\end{array}$ & $\begin{array}{l}0 \\
\stackrel{1}{0} \\
\infty\end{array}$ & 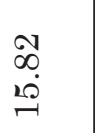 & 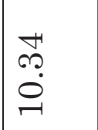 & 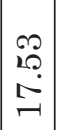 & $\begin{array}{l}10 \\
10 \\
\infty\end{array}$ & $\begin{array}{l}\stackrel{+}{\sim} \\
\stackrel{2}{ } \\
\stackrel{\sim}{\sim}\end{array}$ & \\
\hline $\mid \begin{array}{c}0 \\
z \\
0 \\
0 \\
\vdots \\
0 \\
0\end{array}$ & क्रि0 & $\begin{array}{l}10 \\
10\end{array}$ & $\stackrel{\leftrightarrow}{-}$ & $\stackrel{0}{+}$ & $\stackrel{\oplus}{0}$ & $\begin{array}{l}10 \\
10\end{array}$ & $\begin{array}{l}\sigma \\
\infty \\
\infty\end{array}$ & $\stackrel{\leftrightarrow}{-}$ & $\stackrel{\leftrightarrow}{0}$ & 年 \\
\hline$z$ & $\sum_{i}^{\infty}$ & 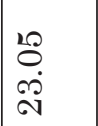 & & $\begin{array}{l}\infty \\
10 \\
\stackrel{1}{+} \\
\stackrel{1}{|c|}\end{array}$ & $\begin{array}{l}0 \\
\text { N. } \\
\stackrel{\sim}{*}\end{array}$ & $\begin{array}{l}\stackrel{ }{P} \\
\underset{\text { H }}{ }\end{array}$ & $\begin{array}{l}\stackrel{+}{\infty} \\
0 \\
0 \\
-1\end{array}$ & & 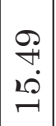 & 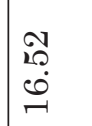 \\
\hline & ن & 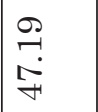 & & 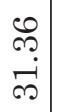 & 官 & & & ָூ & $\begin{array}{l}\curvearrowright \\
\sigma \\
\infty \\
\sim \\
\sim\end{array}$ & \\
\hline & $\dot{\vec{E}}$ & $\stackrel{\text { 9 }}{+}$ & $\begin{array}{l}0 \\
\vdots \\
10\end{array}$ & $\begin{array}{l}\infty \\
0 \\
10 \\
10\end{array}$ & 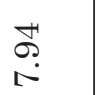 & $\begin{array}{l}\infty \\
\infty \\
0 \\
0\end{array}$ & $\begin{array}{l}0 \\
\stackrel{\sim}{\sim}\end{array}$ & $\mid \begin{array}{l}10 \\
10 \\
\infty\end{array}$ & $\begin{array}{l}\stackrel{8}{8} \\
\infty\end{array}$ & $\begin{array}{l}20 \\
0.0 \\
0.0\end{array}$ \\
\hline \multirow{5}{*}{ 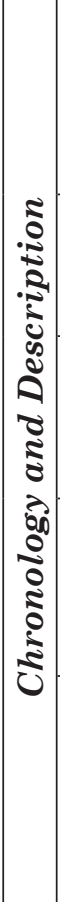 } & 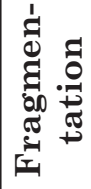 & 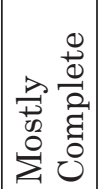 & 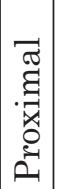 & 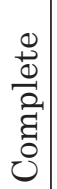 & 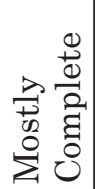 & 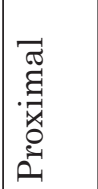 & 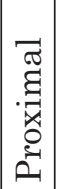 & 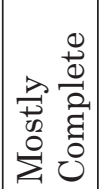 & 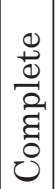 & 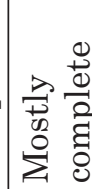 \\
\hline & 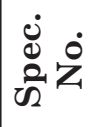 & $\begin{array}{l}0 \\
\dot{1} \\
\dot{1} \\
0 \\
0\end{array}$ & 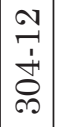 & $\begin{array}{l}\infty \\
\stackrel{2}{+} \\
\dot{+} \\
\stackrel{\infty}{\infty}\end{array}$ & $\begin{array}{l}\infty \\
\infty \\
10 \\
10\end{array}$ & 芯 & 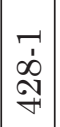 & 辛 & $\begin{array}{l}\stackrel{1}{1} \\
\dot{\vec{s}} \\
\stackrel{-}{1}\end{array}$ & 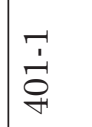 \\
\hline & 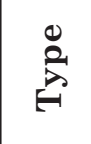 & $\stackrel{\mathscr{A}}{\rightrightarrows}$ & \multicolumn{2}{|c|}{ 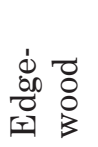 } & 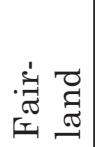 & 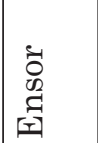 & $\mid \begin{array}{l}\overrightarrow{\dot{z}} \\
\dot{\varpi}\end{array}$ & 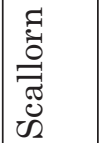 & \multicolumn{2}{|l|}{. } \\
\hline & & $\frac{\pi}{Z}$ & $\frac{\pi}{Z}$ & & 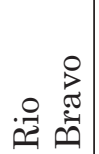 & 界密 & 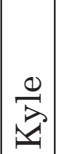 & 苗 & \multicolumn{2}{|l|}{ 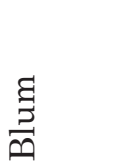 } \\
\hline & 罚 & \multicolumn{5}{|l|}{ 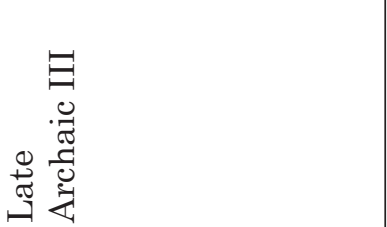 } & \multicolumn{2}{|c|}{ 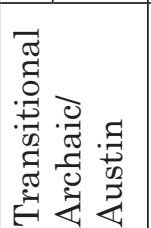 } & \multicolumn{2}{|c|}{ 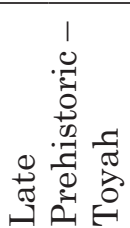 } \\
\hline
\end{tabular}



Table B. Biface Data from All Excavation Units

\begin{tabular}{|c|c|c|c|c|c|c|c|}
\hline $\begin{array}{c}\text { Spec } \\
\text { No. }\end{array}$ & Unit & Level & Fragmentation & $\begin{array}{c}\text { Length } \\
\text { (mm) }\end{array}$ & $\begin{array}{c}\text { Width } \\
(\mathrm{mm})\end{array}$ & $\begin{array}{c}\text { Thick- } \\
\text { ness } \\
\text { (mm) }\end{array}$ & $\begin{array}{c}\text { Weight } \\
\text { (g) }\end{array}$ \\
\hline $103-9$ & 1 & 4 & $\begin{array}{l}\text { End missing: Proximal } \\
\text { and one edge }\end{array}$ & & & 5.03 & 4.7 \\
\hline $104-13$ & 1 & 5 & End only & & & 12.99 & 24.6 \\
\hline $105-3$ & 1 & 6 & Medial: Edge Fragment & & & 11.63 & 9.6 \\
\hline $200-5$ & 2 & 1 & Medial & & & 15.34 & 40 \\
\hline $202-2$ & 2 & 3 & End only: Distal & & & 5.33 & 7.6 \\
\hline $5-2$ & 2 & 4 & End missing: Distal & & 55.92 & 15.41 & 72.6 \\
\hline $204-2$ & 2 & 5 & End only & & & 20.37 & 95.2 \\
\hline $304-2$ & 3 & 5 & End only: Proximal & & 42.92 & 8.08 & 19.7 \\
\hline $305-48$ & 3 & 6 & Medial: Edge Fragment & & & 11.75 & 10.4 \\
\hline $306-7$ & 3 & 7 & End only & & & 15.95 & 52.4 \\
\hline $308-44$ & 3 & 9 & Medial & & 43.38 & 12.68 & 32.3 \\
\hline $308-6$ & 3 & 9 & End only: Proximal & & 40.27 & 14.09 & 22.8 \\
\hline $312-7$ & 3 & 13 & End only: Distal & & & 9.18 & 20.7 \\
\hline $328-1$ & 3 & 13,14 & End only: Distal & & & 10.25 & 27.3 \\
\hline $313-1$ & 3 & 14 & End only: Proximal & & 31.85 & 8.63 & 14.5 \\
\hline $313-19$ & 3 & 14 & Medial & & & 11.32 & 16 \\
\hline $313-41$ & 3 & 14 & End only: Proximal & & 40.69 & 12.11 & 18 \\
\hline $314-4$ & 3 & 15 & Medial & & & 6.03 & 3.3 \\
\hline $315-17$ & 3 & 16 & End only: Distal & & & 6.93 & 1.9 \\
\hline $316-3$ & 3 & 17 & End only & & & 9.38 & 15 \\
\hline $339-1$ & 3 & 1 & Medial & & & 8.9 & 16 \\
\hline $401-3$ & 4 & 2 & Complete & 55.80 & 41.37 & 10.84 & 22.8 \\
\hline $403-2$ & 4 & 4 & End only: Distal & & & 5.55 & 5.3 \\
\hline $403-3$ & 4 & 4 & End only: Distal & & & 8.06 & 13.6 \\
\hline $404-1$ & 4 & 5 & Complete & 61.87 & 42.97 & 14.12 & 32 \\
\hline $404-3$ & 4 & 5 & Medial & & & 6.99 & 7.2 \\
\hline $405-3$ & 4 & 6 & End only: Proximal & & 46.91 & 8.84 & 15.5 \\
\hline $407-10$ & 4 & 8 & End only: Proximal & & 44.55 & 11.16 & 27.4 \\
\hline $407-15$ & 4 & 8 & End only: Distal & & & 5.74 & 2.9 \\
\hline $407-2$ & 4 & 8 & End only: Distal & & & 8.9 & 8.3 \\
\hline $407-9$ & 4 & 8 & Medial & & & 12.37 & 17.5 \\
\hline $408-4$ & 4 & 9 & Medial: Edge Fragment & & & 6.54 & 1.4 \\
\hline $409-10$ & 4 & 10 & Medial & & & 9.01 & 15.9 \\
\hline $409-12$ & 4 & 10 & End only & & & 10.81 & 31.2 \\
\hline
\end{tabular}


Table B. Biface Data from All Excavation Units

\begin{tabular}{|l|l|l|l|c|c|c|c|}
\hline $\begin{array}{c}\text { Spec } \\
\text { No. }\end{array}$ & Unit & Level & \multicolumn{1}{|c|}{ Fragmentation } & $\begin{array}{c}\text { Length } \\
(\mathbf{m m})\end{array}$ & $\begin{array}{c}\text { Width } \\
(\mathbf{m m})\end{array}$ & $\begin{array}{c}\text { Thick- } \\
\mathbf{n e s s} \\
(\mathbf{m m})\end{array}$ & $\begin{array}{c}\text { Weight } \\
(\mathbf{g})\end{array}$ \\
\hline $409-13$ & 4 & 10 & End only: Distal & & & 7.99 & 5.7 \\
\hline $409-8$ & 4 & 10 & End only: Proximal & & 47.36 & 13.9 & 22.4 \\
\hline $411-1$ & 4 & 12 & End only: Distal & & & 8.41 & 13.2 \\
\hline $411-3$ & 4 & 12 & Medial & & & 9.05 & 14.5 \\
\hline $412-1$ & 4 & 13 & Medial: Edge Fragment & & & 5.79 & 2.1 \\
\hline $412-2$ & 4 & 13 & End only: Distal & & & 12.26 & 26.5 \\
\hline $414-16$ & 4 & 15 & End only: Distal & & & 12.77 & 13.2 \\
\hline $414-19$ & 4 & 15 & Medial & & & 14.02 & 25.5 \\
\hline $430-2$ & 4 & n/a & End only: Distal & & & 9.62 & 17.6 \\
\hline
\end{tabular}


Appendix C

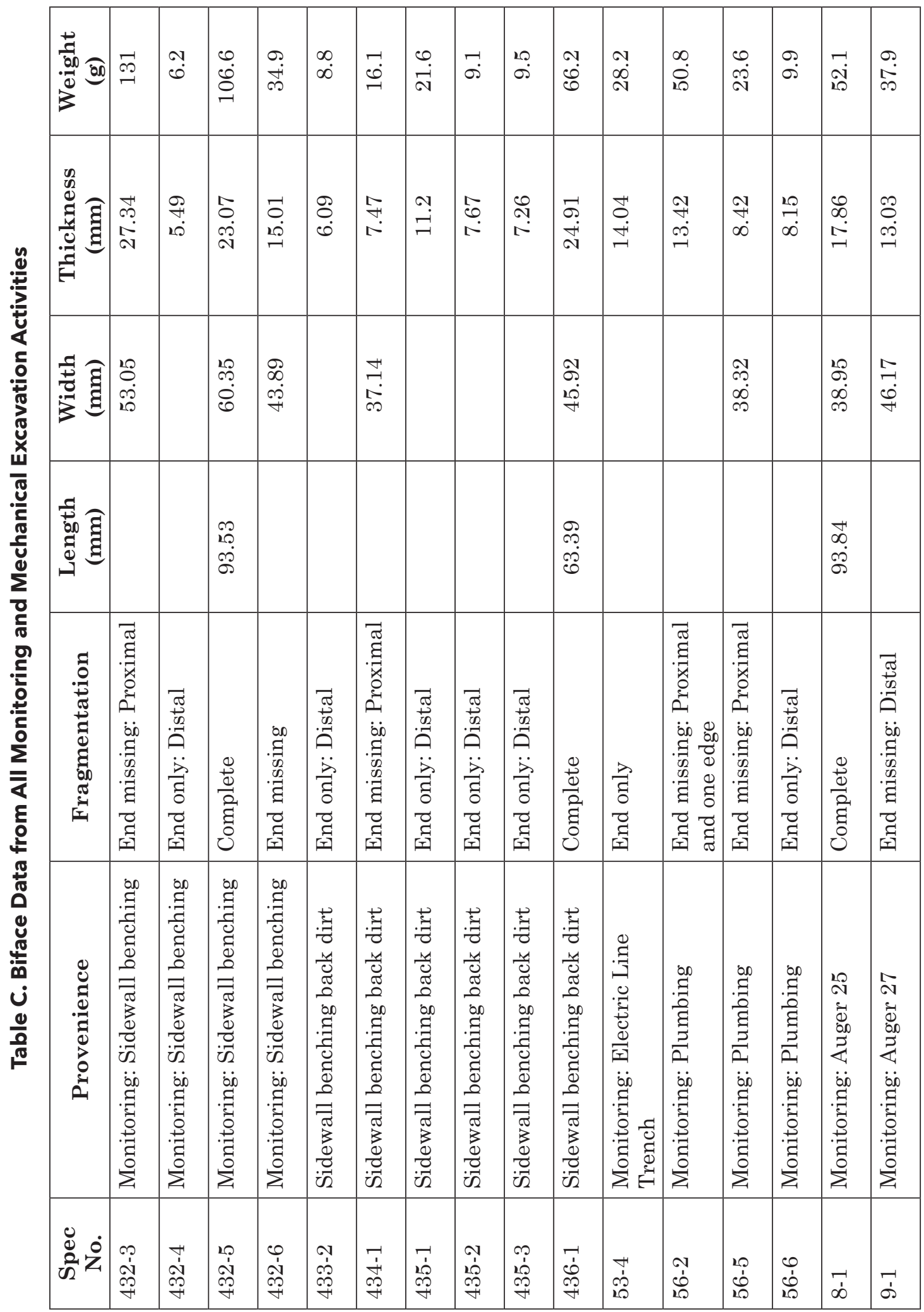





\section{References}

Aery, D. A.

2007 Organization of Lithic Technology in Archaic Texas: An Example from 41HY160 in San Marcos, Texas. Unpublished Master's thesis, Texas State University-San Marcos.

Alley, William M.

1984 The Palmer Drought Severity Index: Limitations and Assumptions. Journal of Climate and Applied Meteorology 23:1100-1109.

Ambrose, S. H.

1990 Preparation and Characterization of Bone and Tooth Collagen for Isotopic Analysis. Journal of Archaeological Science 17:431-451.

1991 Effects of Diet, Climate and Physiology on Nitrogen Isotope Abundances in Terrestrial Foodwebs. Journal of Archaeological Science 18:293-317.

Ambrose, S. H., and M. J. DeNiro

1986 The Isotopic Ecology of East African Mammals. Oecologia 69:395-406.

Ambrose, S. H., and L. Norr

1993 Experimental Evidence for the Relationship of the Carbon Isotope Ratios of Whole Diet and Dietary Protein to those of Bone Collagen and Carbonate. In Prehistoric Human Bone: Archaeology at the Molecular Level, edited by J. B. Lambert and G. Grupe, pp. 1-37. Springer-Verlag, New York.

Arnn, John Wesley, III

2012 Land of the Tejas: Native American Identity and Interaction in Texas, AD 13001700. The University of Texas Press, Austin.

Arnn, John W., III, and Karl W. Kibler

1999 Archeological Survey and Geomorphological Assessment for the Proposed Spring Lake Water Line, Hays County, Texas. Technical Reports No. 41. Prewitt and Associates, Inc., Austin.

Auerbach, Benjamin M., and Christopher B. Ruff

2004 Human Body Mass Estimation: a Comparison of "Morphometric" and "Mechanical" Methods. American Journal of Physical Anthropology 125:331-342.

Auerbach, Benjamin M., and Christopher B. Ruff

2010 Stature Estimation Formulae for Indigenous North American Populations. American Journal of Physical Anthropology 141:190-207. 


\section{References Cited}

Barnes, Virgil E.

1974 Geologic Atlas of Texas, Seguin Sheet. Bureau of Economic Geology, The University of Texas, Austin.

Batte, C. D.

1984 Soil Survey of Comal and Hays Counties Texas. U. S. Department of Agriculture, Soil Conservation Service, Washington, D.C.

Bement, Leland C., Ernest L. Lundelius, Jr., and Richard A. Ketcham

2005 Hoax or History: A Bison Skull with Embedded Calf Creek Projectile Point. Plains Anthropologist 50:221-226.

Berger R., A. G. Horney, and W. F. Libby

1964 Radiocarbon Dating of Bone and Shell from their Organic Components. Science 144:999-1001.

Binford, Lewis R.

2001 Constructing Frames of Reference: An Analytical Method for Archaeological TheoryBuilding Using Hunter-Gatherer and Environmental Data Sets. University of California Press, Berkeley.

Black, Stephen L.

1986 The Clemente and Herminia Hinojosa Site 41JW8: A Toyah Horizon Campsite in Southern Texas. Special Report 18, Center for Archaeological Research, The University of Texas at San Antonio.

1989 Central Texas Plateau Prairie. In From the Gulf Coast to the Rio Grande: Human Adaptation in the Central, South, and Lower Pecos, Texas, edited by Thomas R. Hester, Stephen L. Black, D. Gentry Steele, Ben W. Olive, Anne A. Fox, Karl J. Reinhard, and Leland C. Bement, pp.17-38. Research Series No. 33, Arkansas Archeological Survey, Fayetteville.

Blair, W. Frank

1950 The Biotic Provinces of Texas. Texas Journal of Science 2(1):93-117.

Blum, Michael D., and Salvatore Valastro, Jr.

1989 Response of the Pedernales River of Central Texas to Late Holocene Climatic Change. Annals of the Association of American Geographers 79(3):435-456.

Bolton, Herbert E.

1970 [1915] Texas in the Middle Eighteenth Century: Studies in Spanish Colonial History and Administration, Vol. 3. University of California Publications in History. University of California, Berkeley. 
Bomar, George W.

1983 Texas Weather. University of Texas Press, Austin.

Bousman, C. Britt

1998 Paleoenvironmental Change in Central Texas: The Palynological Evidence. Plains Anthropologist 43:201-219.

Bousman, C. Britt, Barry W. Baker, and Anne C. Kerr

2004 Paleoindian Archeology in Texas. In The Prehistory of Texas, edited by Timothy K. Perttula, pp. 15-97. Texas A\&M Press, College Station.

Bousman, C. B., M. B. Collins, P. Goldberg, T. Stafford, J. Guy, B. W. Baker, D. G. Steele, M. Kay, G. Fredlund, P. Dering, S. Dial, V. Holliday, D. Wilson, P. Takac, R. Balinsky, M. Masson, and J. F. Powell

2002 The Paleoindian-Archaic Transition: New Evidence from Texas. Antiquity 76:980 990.

Bousman, C. Britt, and David L. Nickels (editors)

2003 Archaeological Testing of the Burleson Homestead at 41HY37, Hays County, Texas. Archaeological Studies Report No. 4, Center for Archaeological Studies, Texas State University-San Marcos.

Bronk Ramsey, Christopher, Thomas Higham, Angela Bowles, and Robert Hedges

2004 Improvements to the Pretreatment of Bone at Oxford. Radiocarbon 46:155-163.

Brown T. A, D. E. Nelson, J. S. Vogel, and J. R. Southon

1988 Improved Collagen Extraction by Modified Longin Method. Radiocarbon 30:171-7.

Buikstra, Jane E., and Herbert D. Ubelaker

1994 Standards for Data Collection from Human Skeletal Remains: Proceedings of a Seminar at the Field Museum of Natural History. Arkansas Archaeological Research Series, Fayetteville.

Byrd, Julia C.

2011 Archaic Bone Tools in the St. Johns River Basin, Florida: Microwear and Manufacture Traces. Unpublished Master's thesis. Florida State University.

Calame, David, Sr., Carey Weber, Larry Banks, and Richard McReynolds

2002 Projectile Points of the Calf Creek Horizon from Frio, Medina, and Uvalde Counties, Southern Texas. La Tierra 29:29-38. 


\section{References Cited}

Campbell, T. N., and T. J. Campbell

1985 Indian Groups Associated with Spanish Missions of the San Antonio Missions National Historical Park. Special Report No. 16, Center for Archaeological Research, The University of Texas at San Antonio.

Cargill, Diane A.

1996 Stable Isotope Analysis at Mission San Juan de Capistrano, San Antonio, Texas. Unpublished Master's thesis, Department of Anthropology, University of Texas at San Antonio.

Chandler, C. K., and Don Kumpe

1993 Stemmed Points with Massive Barbs from the Lower Rio Grande Valley. La Tierra $20: 26-28$

Collins, Michael B.

1994 Evidence of Early Archaic Occupation. In Archaic and Late Prehistoric Human Ecology in the Middle Onion Creek Valley, Hays County, Texas. Volume 1, Archeological Components, by Robert A. Ricklis and Michael B. Collins, pp. 67-100. Studies in Archeology 19, Texas Archeological Research Laboratory, The University of Texas at Austin.

1995 Forty Years of Archeology in Central Texas. Bulletin of the Texas Archeological Society 66:361-400.

Collins, Michael B. (assembler and editor)

1998 Wilson-Leonard: An 11,000-year Archeological Record in Central Texas. 6 Vols. Studies in Archeology 31. Texas Archeological Research Laboratory, The University of Texas at Austin. Archeology Studies Program Report 10. Texas Department of Transportation, Environental Affairs Division, Austin.

Collins, Michael B., and Kenneth M. Brown

2000 The Gault Gisement: Some Preliminary Observations. Current Archeology in Texas 2(1):163-166.

Collins, Michael B., David M. Yelacic, and C. Britt Bousman

2011 "Realms." A Look at Paleoclimate and Projectile Points across Texas. Bulletin of the Texas Archeological Society 82:3-30.

Cook, Edward R., David M. Meko, David W. Stahle, and Malcom K. Cleaveland

1999 Drought Reconstructions for the Continental United States. Journal of Climate 12:1145-1162. 
Cormie, A. B., and H. P Schwarcz

1994 Stable Isotopes of Nitrogen and Carbon of North American White-Tailed Deer and Implications for Paleodietary and Other Food Web Studies. Paleogeography, Paleoclimatology, Paleoecology 107:227-241.

Cormie, A. B., and H. P Schwarcz

1996 Effects of Climate on Deer Bone $\delta^{15} \mathrm{~N}$ and $\delta^{13} \mathrm{C}$ : Lack of Precipitation Effects on $\delta^{15} \mathrm{~N}$ for Animals Consuming Low Amounts of C4 Plants. Geochimica et a Cosmochinica Acta 60:4161-4166.

Crumley, Carole L. (editor)

1994 Historical Ecology: Cultural Knowledge and Changing Landscapes. School of American Research Press, Santa Fe.

de la Teja, Jesús F.

1995 San Antonio de Bexár: A Community on New Spain's Northern Frontier. University of New Mexico Press, Albuquerque.

Dickson, Don R.

1970 Excavations at Calf Creek Cave. The Arkansas Archeologist 11:50-82.

Dillehay, Thomas D.

1974 Late Quaternary Bison Population Changes on the Southern Plains. Plains Anthropologist 19(64):180-196.

Dixon, Richard

2000 Climatology of the Freeman Ranch, Hays County, Texas. Freeman Ranch Publication Series No. 3-2000, Texas State University-San Marcos.

Dobie, Dudley R.

1932 The History of Hays County, Texas. Unpublished Master's thesis, The University of Texas at Austin.

Dreiss, Meredith L.

1994 Marine and Freshwater Shell Artifacts. In Aboriginal Life and Culture on the Upper Texas Coast: Archaeology at the Mitchell Ridge Site, 41GV66, Galveston Island, edited by Robert A. Ricklis, pp. 417-445. Coastal Archaeological Research, Inc., Corpus Christi.

2009 Marine Shell Ornaments, Icons and Offerings. Electronic document, http://www. texasbeyondhistory.net/coast/nature/images/shell-ornaments.html, accessed 20 March, 2013. 


\section{References Cited}

Dunn, William E.

1911 Apache Relations in Texas, 1718-1750. Southwestern Historical Quarterly 14:198274.

Ellis, Linda Wootan, G. Lain Ellis, and Charles D. Frederick

1995 Implications of Environmental Diversity in the Central Texas Archeological Region. Bulletin of the Texas Archeological Society 66:401-426.

Ellis, Linda W., and Timothy K. Perttula (assemblers and editors)

2010 Regional Summaries of Prehistoric and Early Historic Ceramics in Texas for the Council of Texas Archeologists. Electronic Document, http:// counciloftexasarcheologists.org/wordpress/wp-content/uploads/Regional-SummariesCeramics.pdf, accessed 20 March, 2013.

Eren, Metin I. (editor)

2012 Hunter-Gatherer Behavior: Human Response during the Younger Dryas. Left Coast Press, Walnut Creek, California.

Fisher, Lewis F.

1998 The Spanish Missions of San Antonio. Maverick Publishing Company, San Antonio.

Ford, Owen A., and Anthony S. Lyle

1998 Archaeological Investigation of a Spring Lake Lot for Joe’s Crab Shack Parking. Archaeological Survey Report No. 277, Center for Archaeological Research, University of Texas at San Antonio.

Foster, William C.

1995 Spanish Expeditions into Texas 1689-1768. The University of Texas Press, Austin.

Froehle, A. W., C. M. Kellner, and M. J. Schoeninnger

2010 FOCUS: Effect of Diet and Protein Source on Carbon Stable Isotope Ratios in Collagen: Follow up to Warinner and Tuross (2009). Journal of Archaeological Science 37:2662-2670.

2012 Multivariate Carbon and Nitrogen Stable Isotope Model for the Reconstruction of Prehistoric Human Diet. American Journal of Physical Anthropology 147:352-369.

Garber, James F., S. Bergman, B. Dickinson, R. Hays III, J. Simpson, and J. Stefanoff

1983 Excavations at Aquarena Springs, San Marcos, Texas. La Tierra 10:2:28-38.

Garber, James F., and David M. Glassman

1992 Excavation of Human Remains from the Fish Pond Site, 41HY161, in San Marcos, Hays County, Texas. Department of Sociology and Anthropology, Southwest Texas State University. 
Garber, James F., and M. D. Orloff

1984 Excavations at 41HY37: an Archaic site on the Balcones Escarpment in San Marcos, Texas. La Tierra 11:3:31-37.

Giesecke, J.

1998 Faunal Analysis from 41HY165: an Independent Study. Manuscript on file, Anthropology Department, Southwest Texas State University, San Marcos.

Gilbert, R., and G. W. Gill

1990 A metric technique for identifying American Indian femora. In Skeletal Attribution of Race: Methods for Forensic Anthropology, edited by G. W. Gill and S. Rhine, pp 97-99. Anthropological Papers No. 4, Maxwell Museum of Anthropology. University of New Mexico, Albuquerque.

Goldstein, Lynne, and Keith Kintigh

2000 Ethics and the Reburial Controversy. In Repatriation Reader: Who Owns American Indian Remains? edited by Devon A. Mihesuah, pp. 180-189. University of Nebraska Press, Lincoln.

Griffitts, J. L.

2006 Bone Tools and Technological Choice: Change and Stability on the Northern Plains (North Dakota). Unpublished Ph. D. dissertation, Department of Anthropology, University of Arizona, Tuscon.

Habig, Marion A.

1977 The Alamo Mission: San Antonio de Valero, 1718-1793. Franciscan Herald Press, Chicago.

Hall, Grant D.

1981 Allens Creek: A Study in the Cultural Prehistory of the Brazos River Valley, Texas. Texas Archaeological Survey Research Report No. 61, The University of Texas at Austin.

Hard, Robert J., and M. Anne Katzenberg

2011 Stable Isotope Study of Hunter-Gatherer-Fisher Diet, Mobility, and Intensification on the Texas Gulf Coastal Plain. American Antiquity 76:709-751.

Hedges, R. E. M., and G. J. Van Klinken

1992 A Review of Current Approaches in the Pretreatment of Bone for Radiocarbon Dating by AMS. Radiocarbon 34:279-291. 


\section{References Cited}

Hester, Thomas R.

1971 Marine Shells from Archaeological Sites in Southwestern Texas. Texas Journal of Science 22:87-88.

1980 A Survey of Paleo-Indian Remains along the Texas Coast. In: Papers on the Archaeology of the Texas Coast, edited by Cynthia L. Highley and Thomas R. Hester, pp. 1-12. Special Report No. 11, Center for Archaeological Research, University of Texas at San Antonio.

1983 Late Paleo-Indian Occupations at Baker Cave, Southwestern Texas. Bulletin of the Texas Archeological Society 53:101-119.

1995 The Prehistory of South Texas. Bulletin of the Texas Archeological Society 66:427459.

Highley, Cynthia L.

1986 Archaeological Investigations at 41LK201, Choke Canyon Reservoir, Southern Texas. Choke Canyon Series Volume 11, Center for Archaeological Research, The University of Texas at San Antonio.

Houk, Brett A., Kevin A. Miller, and Eric R. Oksanen

2008 The Gatlin Site (41KR621): Investigating Archaic Lifeways on the Southern

Edwards Plateau of Central Texas. SWCA Cultural Resources Report No. 149, and Texas Department of Transportation Archeological Studies Program Report No. 108, Austin.

Huls, M. C., P. M. Grootes, and M.-J. Nadeau

2007 How Clean is Ultrafiltration Cleaning of Bone Collagen? Radiocarbon 49:193-200.

2009 Ultrafiltration: Boon or Bane? Radiocarbon 51:613-625.

Jantz, R. L., and S. D. Ousley

2005 FORDISC 3.0: Personal Computer Forensic Discriminant Functions. The University of Tennessee, Knoxville.

Jelks, Edward B.

1962 The Kyle Site: A Stratified Central Texas Aspect Site in Hill County, Texas. Archaeology Series No. 5, Department of Anthropology, The University of Texas at Austin.

1978 Diablo Range. In Chronologies in New World Archaeology, edited by R. E. Taylor and Clement W. Meighan, pp. 71-111. Academic Press, New York.

Johnson, LeRoy, Jr., and T. N. Campbell

1992 Sanan: Traces of a Previously Unknown Aboriginal Language in Colonial Coahuila and Texas. Plains Anthropologist 37(140):185-212. 
Johnson, LeRoy, Jr., and Glenn T. Goode

1994 A New Try at Dating and Characterizing Holocene Climates, as well as Archeological Periods, on the Eastern Edwards Plateau. Bulletin of the Texas Archeological Society 65:1-51.

Johnson, Amber L., and Robert J. Hard

2008 Exploring Texas Archaeology with a Model of Intensification. Plains Anthropologist 53:137-153.

Joines, Jason Paul

2005 17,000 Years of Climate Change: The Phytolith Record from Hall's Cave, Texas. Unpublished Master's thesis, Department of Biology, Oklahoma State University, Stillwater.

Jones, Richard

2002 Archaeological Trench Monitoring Near Prehistoric Site 41HY161, Hays County, Texas. Technical Report No. 3, Center for Archaeological Studies, Texas State University-San Marcos.

Kellner, C. M., and M. J. Schoeninger

2007 A Simple Carbon Isotope Model for Reconstructing Prehistoric Human Diet. American Journal of Physical Anthropology 133: 1112-1127.

Kintigh, Keith W.

1984 Measuring Archaeological Diversity by Comparison with Simulated Assemblages. American Antiquity 49(1):44-54.

1989 Sample Size, Significance, and Measures of Diversity. In Quantifying Diversity in Archaeology, edited by Robert D. Leonard and George T. Jones, pp. 25-36. Cambridge University Press, Cambridge.

Krueger, H. W., and C. H. Sullivan

1984 Models for Carbon Isotope Fraction Between Diet and Bone. In Stable Isotopes and Nutrition, edited by J. R. Turnland and P. E. Johnson, pp. 205-220. ACS Symposium Series, No. 258. Washington: American Chemical Society.

LaBelle, Jason M.

2012 Hunter-Gatherer Adaptations of the Central Plains and Rocky Mountains of Western North America. In Hunter-Gatherer Behavior: Human Response during the Younger Dryas, edited by Metin I. Eren, pp. 139-164. Left Coast Press, Walnut Creek. 


\section{References Cited}

LeDoux, Spencer, and Jon C. Lohse

2011 Projectile Points. In Prehistoric Life, Labor, and Residence in Southeast Central Texas: Results of Data Recovery at 41HY164, the Zatopec Site, San Marcos, Texas, edited by Jon C. Lohse, pp. 192-225. Archaeological Studies Report No. 18, Center for Archaeological Studies, Texas State University-San Marcos.

Leezer, Carole, Julian A. Sitters, and Sarah Scogin

2010 Archaeological Assessment and Monitoring for Construction of a New Boiler Station at Jowers Center and Sewell Park, Texas State University-San Marcos, Hays County, Texas. Technical Report No. 38, Center for Archaeological Studies, Texas State University-San Marcos.

Leezer, Carole, David Yelacic, Jon C. Lohse, and Frederick Hanselmann

2011 Results of Cultural Resources Survey for the Spring Lake Section 206 Aquatic Ecosystem Restoration Project. Archaeological Studies Report No. 22, Center for Archaeological Studies, Texas State University-San Marcos.

Lemke, Ashley, and Cinda Timperley

2008 Preliminary Analysis of Turtle Material from the Gault Site, Texas. Current Research in the Pleistocene 25:115-117.

Lohse, Jon C.

1999 Lithics from the San Antonio de Valero Mission: Analysis of Materials from 1979

Excavations at the Alamo. Bulletin of the Texas Archeological Society 70:265-279.

Lohse, Jon C. (editor)

2013a Defining the Middle Archaic at Spring Lake: Data Recovery and Analysis at 41 HY160 for the Texas Rivers Center, Texas State University-San Marcos, Hays County, Texas. Archaeological Studies Report No. 29, Center for Archaeological Studies, Texas State University-San Marcos.

Lohse, Jon C. (editor)

2013b Underwater Archaeology at 41HY147, the Terrace Locality at Spring Lake. Archaeological Studies Report No. 28, Center for Archaeological Studies, Texas State University-San Marcos.

Lohse, Jon C., Stephen L. Black, and Laly M. Cholak

2014 Toward an Improved Archaic Radiocarbon Chronology for Central Texas. Bulletin of the Texas Archeological Society, in press. 
Lohse, Jon C., Andrew Hemmings, Michael B. Collins, and David M. Yelacic

2013 Putting the Specialization Back in Clovis: What Some Caches Reveal about Skill and the Organization of Production in the Terminal Pleistocene. In An Extraordinary Collection of Chipped Stone Artifacts: Recent Research on Clovis Caches, edited by Bruce B. Huckell and J. David Kilby. University of New Mexico Press, Albuquerque, in press.

Lohse, Jon C., Douglas J. Kennett, Brendan J. Culleton, and Cinda L. Timperley

2012 Middle-to-Late Holocene Bison Chronology and Ecology in the South-Central United States. Paper presented at the 77th Annual Meeting of the Society for American Archaeology, Memphis.

Longin, R.

1971 New Method of Collagen Extraction for Radiocarbon Dating. Nature 230:241-242.

Lukowski, P. D.

1988 Archaeological Investigations at 41BX1, Bexar County, Texas. Archaeological Survey Report 135, Center for Archaeological Research, The University of Texas at San Antonio.

Lyle, Anthony, Christopher Horrell, Steve A. Tomka, and Diane A. Cargill

2000 Archaeological Testing at the Headwaters of the San Marcos River: Southwest Texas State University Raw Water Supply Project. Archaeological Survey Report No. 293, Center for Archaeological Research, University of Texas at San Antonio.

McGraw, Al J., John W. Clarke Jr., and Elizabeth A. Robbins (editors)

1991 A Texas Legacy: The Old San Antonio Road and the Caminos Reales, a Tricentennial History, 1691-1991. Texas State Department of Highways and Public Transportation, Austin.

Mauldin, Raymond P., Robert J. Hard, Cynthia M. Munoz, Jennifer L. Z. Rice, Kirsten Verostick, Daniel R. Potter, and Nathanael Dollar

2013 Carbon and Nitrogen Stable Isotope Analysis of Hunter-Gatherers from the Coleman Site, a Late Prehistoric Cemetery in Central Texas. Journal of Archaeological Science 40:1369-1381.

Mauldin, Raymond P., Jennifer L. Thompson, and Leonard Kemp

2012 Reconsidering the Role of Bison in the Terminal Late Prehistoric (Toyah) Period in Texas. In The Toyah Phase of Central Texas, edited by Nancy Kenmotsu and Doug Boyd, pp. 90-110. Texas A\&M University Press, College Station.

Meltzer, David J.

1999 Human Responses to Middle Holocene (Altithermal) Climates on the North American Great Plains. Quaternary Research 52:404-416. 


\section{References Cited}

2006 Folsom: New Archaeological Investigations of a Classic Paleoindian Bison Kill. University of California Press, Berkeley.

Munoz, Cynthia M

2011 Paleoclimate. In Archeological Significance Testing at 41BX17/271, the Granberg Site: A Multi-Component Site along the Salado Creek in Bexar County, Texas, by Cynthia M. Munoz, Raymond P. Mauldin, Jennifer L. Thompson, and S. Christopher Caran, pp. 95-104. Texas Department of Transportation, Environmental Affairs Division Archeological Studies Program, Report No. 140, Austin, and Center for Archaeological Studies, The University of Texas at San Antonio, Archaeological Report No. 393, San Antonio.

Munoz, Cynthia M., Raymond Mauldin, and Robert J. Hard

2011 Stable Isotope Analysis of Human Skeletal Remains from 41HY163 with Comparative Analysis of Remains from 41HY161. In Prehistoric Life, Labor, and Residence in Southeast Central Texas: Results of Data Recovery at 41HY163, the Zatopec Site, San Marcos, Texas, edited by Jon C. Lohse, pp. 343-350. Archaeological Studies Report No. 18, Center for Archaeological Studies, Texas State University-San Marcos.

Musgrove, MaryLynn, Jay L. Banner, Larry E. Mack, Deanna M. Combs, Eric W. James, Hai Cheng, and R. Lawrence Edwards

2001 Geochronology of the late Pleistocene to Holocene Speleothems from Central Texas: Implications for Regional Paleoclimate. GSA Bulletin 113: 1532-1543.

Newcomb, William W., Jr.

1961 The Indians of Texas from Prehistoric to Modern Times. University of Texas Press, Austin.

1993 Historic Indians of Central Texas. Bulletin of the Texas Archeological Society 64:1-63.

Nickels, David L., and C. Britt Bousman

2010 Archaeological Testing at San Marcos Springs (41HY160) for the Texas Rivers Center, Texas, Hays County, Texas. Archaeological Studies Report No. 13, Center for Archaeological Studies, Texas State University-San Marcos.

Nordt, Lee C.

2010 Geology, Landscape Evolution, and Geoarchaeology at Spring Lake. In Archaeological Testing at San Marcos Springs (41HY160) for the Texas Rivers Center, Hays County, Texas, by David L. Nickels and C. Britt Bousman. Archaeological Studies Report No. 13, Center for Archaeological Studies, Texas State University-San Marcos. 
Nordt, Lee C., Thomas W. Boutton, John S. Jacob, and Rolfe D. Mandel

$2002 \mathrm{C}_{4}$ Plant Productivity and Climate- $\mathrm{CO}_{2}$ Variations in South-Central Texas during the Late Quaternary. Quaternary Research 58: 182-118.

Norr, L.

1995 Interpreting Dietary Maize from Bone Stable Isotopes in the New World Tropics: The State of the Art. In Archaeology in the American Tropics: Current Analytical Methods and Applications, edited by P. W. Stahl, pp. 198-223. Cambridge University Press, Cambridge.

Oksanen, Eric

2006 Proposed Fiber Optic Conduit Route at the Aquarena River Center and Golf Course, San Marcos, Hays County, Texas. Technical Report No. 22, Center for Archaeological Studies, Texas State University-San Marcos.

2008 Archaeological Investigations at the Icehouse Site, 41HY161: a Revaluation of Early Archaic Technology, Subsistence and Settlement along the Balcones Escarpment and Central Texas. Unpublished Master's thesis, Department of Anthropology, Texas State University-San Marcos.

2011 Archaeological Investigations at the Ice House Site, 41HY161: Early Archaic Technology, Subsistence, and Settlement along the Balcones Escarpment, Hays County, Texas. Archaeological Studies Report No. 14, Center for Archaeological Studies, Texas State University-San Marcos

Parks, Connie L.

2009 Oxygen Isotope Analysis of Human Bone and Tooth Enamel: Implications for Forensic Investigations. Unpublished Master's thesis, Department of Anthropology, Texas State University-San Marcos.

Penders, Thomas E.

1997 A Study of Form and Function of the Bone and Antler Artifacts from the Windover Archaeolocal Site (8BR246), Brevard County, Florida. Unpublished Master's thesis, Department of Anthropology, Florida State University, Tallahasee.

Peter, D. E., D. Prikryl, O. F. McComick, and M. Demuynck

1982 Site Excavation Reports: Primary Contract. In Archeological Investigations of the San Gabriel Reservoir Districts, Central Texas, edited by Thomas R. Hays, volume 1, pp. 8-1 to 8-297. Report to the U.S. Army Corps of Engineers, Fort Worth District. Archaeology Program, Institute of Applied Sciences, North Texas State University, Denton. 


\section{References Cited}

Prewitt, Elton

1974 Preliminary Archeological Investigations in the Rio Grande Delta Area of Texas. Bulletin of the Texas Archeological Society 45:55-65.

1981 Culture Chronology in Central Texas. Bulletin of the Texas Archeological Society 52:65-89.

1983 Andice: An Early Archaic Dart Point Type. La Tierra 10:1-6.

1995 Distributions of Typed Projectile Points in Texas. Bulletin of the Texas Archeological Society 66:83-173.

Quintero, James Paul

2007 Regional Economic Development: An Economic Base Study and Shift-Share Analysis of Hays County, Texas. Unpublished Master's thesis, Department of Political Science, Texas State University-San Marcos.

Ramsey, Dawn

1997 Archaeological Survey of Aquarena Springs Park, Hays County, Texas. Manuscript on file at Anthropology Department, Southwest Texas State University, San Marcos.

Ricklis, Robert A.

1995 Environmental and Human Adaptive Change on the Nueces Bay Shoreline: Phase I, Archaeological Data Recovery at Koch Refining Middle Plant, Nueces County, Texas. Coastal Archaeological Research, Inc., Corpus Christi.

2011 New Perspectives on the Archaic of the Texas Coastal Plain: The Buckeye Knoll Site (41TV98) on the Lower Guadalupe River near Victoria, Texas. Bulletin of the Texas Archeological Society 82:31-76.

Ringstaff, C. W.

2000 A Study of Landform Evolution and Archaeological Preservation at Site 41HY165, San Marcos, Texas. Unpublished Master's thesis, Department of Geography, Southwest Texas State University, San Marcos.

Schoeninger, M. J. and M. J. DeNiro

1984 Nitrogen and Carbon Isotopic Composition of Bone Collagen from Marine and Terrestrial Animals. Geochimica et Cosmochimica Acta 48:625-639.

Sellards, E. H., W. S. Adkins, and F. B. Plummer

1932 The Geology of Texas, Vol. 1: Stratigraphy. Bulletin No. 3232. Austin: Bureau of Economic Geology, The University of Texas at Austin. 
Shafer, Harry J. and Thomas R. Hester

2013 Projectile Points and other Lithics. In Underwater Archaeology at 41HY147, the Terrace Locality at Spring Lake, edited by Jon C. Lohse. Archaeological Studies Report No. 28, Center for Archaeological Studies, Texas State University-San Marcos.

Shaw, Leslie C.

1998 Modified Bone and Shell. In Wilson-Leonard: An 11,000-year Archaeological Record of Hunter-Gatherers in Central Texas. Vol. 3, Artifacts and Special Artifact Studies, assembled and edited by M. B. Collins, pp. 723-730. Studies in Archaeology 31, Texas Archeological Research Laboratory, The University of Texas at Austin. Report 10, Archeology Studies Program, Texas Department of Transportation, Environmental Affairs Division.

Shiner, Joel L.

1979 Survey and Testing of the Ice House site: San Marcos, Hays County, Texas. Manuscript on file, Joel L. Shiner Collection, Center for Archaeological Studies, Texas State University-San Marcos.

1981 History, Economy, and Magic at a Fresh Water Spring. In The Realms of Gold, Proceedings of the Tenth Conference on Underwater Archaeology, edited by W. A. Cockrell, pp. 202-203. Fathom Eight, San Marino, California.

1983 Large Springs and Early American Indians. Plains Anthropologist 28:99:1-7.

1984 A Reply to Johnson and Holliday. Plains Anthropologist 29:103:71-72.

Singer, Michael J., Kenneth L. Verosub, Pinchas Fine, and Jeff TenPas

1996 A Conceptual Model for the Enhancement of Magnetic Susceptibility in Soils. Quaternary International 34-36: 243-248.

Sitters, Julian A., Jon C. Lohse, and R. Zac Selden

2011 Flake Cores. In Prehistoric Life, Labor, and Residence in Southeast Central Texas: Results of Data Recovery at 41HY164, the Zatopec Site, San Marcos, Texas, edited by Jon C. Lohse, pp. 299-307. Archaeological Studies Report No. 18, Center for Archaeological Studies, Texas State University-San Marcos.

Smith, B. Holly

1984 Patterns of Molar Wear in Hunter-Gatherers and Agriculturalists. American Journal of Physical Anthropology 63:39-56.

Somerville, Andrew D., Mikael Fauvelle, and Andrew W. Froehle

2013 Applying New Approaches to Modeling Diet and Status: Isotopic Evidence for Commoner Resiliency and Elite Variability in the Classic Maya Lowlands. Journal of Archaeological Science 40:1539-1553. 


\section{References Cited}

Sorrow, William M., Harry J. Shafer, and Richard E. Ross

1967 Excavations at Stillhouse Hollow Reservoir. Papers of the Texas Archeological Salvage Project, No. 11. The University of Texas at Austin.

Soucie, Shawn, and David L. Nickels

2003 Archaeological Monitoring of a Tree Planting Project and Installation of the Front Door Welcoming Drive for Texas State University-San Marcos, Hays County, Texas. Technical Report No. 11, Center for Archaeological Studies, Texas State UniversitySan Marcos.

Soucie, Shawn, David L. Nickels, Kevin L. Shubert, and Colby J. Mischefsky

2004 Archaeological Trench Monitoring at the Aquarena Springs Golf Course, San Marcos, Hays County, Texas. Technical Report No. 16, Center for Archaeological Studies, Texas State University-San Marcos.

Spielmann, Katherine A. (editor)

1991 Farmers, Hunters, and Colonists: Interaction Between the Southwest and the Southern Plains. University of Arizona Press, Tucson.

Stafford, Thomas W.

1998 Radiocarbon Chronostratigraphy. In Wilson-Leonard: An 11,000-Year Archeological Record of Hunter-Gatherers in Central Texas, Volume IV: Archeological Features and Technical Analyses, assembled and edited by Michael B. Collins, pp. 10391066. Studies in Archeology 31, Texas Archeological Research Laboratory, The University of Texas at Austin. Archeology Studies Program, Report 10, Texas Department of Transportation, Environmental Affairs Division, Austin.

Stafford, T. W., Jr, K. Brendel, and R. Duhamel

1988 Radiocarbon, ${ }^{13} \mathrm{C}$ and ${ }^{15} \mathrm{~N}$ Analysis of Fossil Bone: Removal of Humates with XAD-2 Resin. Geochimica et Cosmochimica Acta 52:2257-2267.

Stafford, T. W., Jr, P. E. Hare, L. A. Currie, A. J. T. Jull, and D. Donahue

1991 Accelerator Radiocarbon Dating at the Molecular Level. Journal of Archaeological Science 18:35-72.

Story, Dee Ann

1985 Adaptive Strategies of Archaic Cultures of the West Gulf Coastal Plain. In Prehistoric Food Production in North America, edited by Richard I. Ford, pp. 19-56. Anthropological Papers No. 75, Museum of Anthropology, University of Michigan, Ann Arbor. 
Stull, Kyra, and Michelle D. Hamilton

2011 Descriptive Analysis of Three Individual Remains from Zatopec, with Comparative Analysis of Two Additional Sets from 41HY161; Chapter 8: Bioarchaeological Analysis of Human Remains from Zatopec. In Prehistoric Life, Labor, and Residence in Southeast-Central Texas: Results of Data Recovery at 41HY163, the Zatopec Site, San Marcos, Texas. Jon C. Lohse, editor, Archaeological Studies Report No. 18, Center for Archaeological Studies, Texas State University-San Marcos.

Symes, S. A., C. W. Rainwater, E. N. Chapman, D. R. Gipson, and A. L. Piper

2008. Patterned Thermal Destruction of Human Remains in a Forensic Setting. In: The Analysis of Burned Human Remains, edited by C. W. Schmidt and S. A. Symes, pp 15-54. Academic Press, Boston.

Takac, Paul R.

1990 "Homes Bases" and the Paleoindian/Archaic Transition in Central Texas. Paper presented at the 55th Annual SAA Meeting, Las Vegas.

1991a Underwater Excavations at Spring Lake: a Paleoindian Site in Hays County, Texas. Current Research in the Pleistocene 8:46-48.

1991b Paleoindian Occupations at Spring Lake, Hays Co., Texas, Dissertation research proposal. Submitted to the Faculty, Department of Anthropology, Southern Methodist University, Dallas.

Thoms, Alston V.

2008 Ancient Savannah Roots of the Carbohydrate Revolution in South-Central North America. Plains Anthropologist 53:121-136.

2009 Rocks of Ages: Propagation of Hot-Rock Cookery in Western North America. Journal of Archaeological Science 36:573-591.

Thurmond, J. Peter, and Don G. Wyckoff

1999 The Calf Creek Horizon in Northwestern Oklahoma. Plains Anthropologist 44:231250.

Tomka, Steve A., Lori Barkwille Love, Kristi M. Ulrich, and Carole A. Leezer

2013 Ceramic Analysis of Samples from 41HY165, Hays County, Texas. In Prehistoric Life along the Banks of Spring Lake: Results and Analysis of the Southwest Texas Field Schools (1996-1998) at 41HY165, San Marcos, Hays County, Texas, edited by Carole A. Leezer. Archaeological Studies Report No. 31, Center for Archaeological Studies, Texas State University-San Marcos. 


\section{References Cited}

Toomey, Rickard S., III

1993 Late Pleistocene and Holocene Faunal and Environmental Changes at Hall's Cave, Kerr County, Texas. Unpublished Ph.D. dissertation, Department of Geography, University of Texas at Austin.

Trope, Jack F., and Walter R. Echo-Hawk

2000 The Native American Graves Protection and Repatriation Act: Background and Legislative History. In Repatriation Reader: Who Owns American Indian Remains? edited by Devon A. Mihesuah, pp. 123-168. University of Nebraska Press, Lincoln.

Turner, Ellen Sue, Thomas R. Hester, and Richard McReynolds

2011 Stone Artifacts of Texas Indians. 3rd ed. Taylor Trade Publishing, Rowman and Littlefield, Lanham, Maryland.

Tykot, Robert H.

2004 Stable Isotopes and Diet: You are What you Eat. In Proceedings of the International School of Physics "Enrico Fermi" Course CLIV, edited by M. Milazzo and M. Piacentine. IOS Press, Amsterdam.

Weber, Carey

1994 A Replication Technique for Andice/Bell Points. In Archaic and Late Prehistoric Human Ecology in the Middle Onion Creek Valley, Hays County, Texas, Volume 2, Topical Studies, by Robert A. Ricklis and Michael B. Collins, pp. 629-651. Studies in Archeology 19, Texas Archeological Research Laboratory, The University of Texas at Austin.

Weir, Frank

1976 The Central Texas Archaic. Unpublished Ph.D. dissertation, Department of Anthropology, Washington State University, Pullman.

Wheeler, Ryan J., and Ray M. McGee

1994 Report of Preliminary Zoarchaeological Analysis: Groves' Orange Midden. Florida Anthropologist 47:393-403.

White, Christine D., Michael W. Spence, Fred J. Longstaffe, and Kimberley R. Law

2000 Testing the Nature of Teotihuacán Imperialism at Kaminaljuyú Using Phosphate Oxygen-Isotope Ratios. Journal of Anthropological Research 56:535-558.

White, Christine D., Michael W. Spence, Hillary Le-Q. Stuart-Williams, and Henry P. Schwarcz

1998 Oxygen Isotopes and the Identification of Geographical Origins: The Valley of Oaxaca versus the Valley of Mexico. Journal of Archaeological Science 25:643-655. 
White, Christine D., Rebecca Storey, Fred J. Longstaffe, and Michael W. Spence

2004 Immigration, Assimilation, and Status in the Ancient City of Teotihuacan: Stable Isotopic Evidence from Tlajinga 33. Latin American Antiquity 15:176-198.

Woodruff, C. M., Jr.

1979 Land Resource Overview of the Capital Area Planning Council Region, Texas - A Nontechnical Guide. Bureau of Economic Geology, The University of Texas at Austin.

Wyckoff, Don G.

1994 Introduction to the 1991 Bulletin. Bulletin of the Oklahoma Anthropological Society Volume XL for 1991, pp. 1-8.

1995 A Summary of the Calf Creek Horizon in Oklahoma. Bulletin of the Oklahoma Anthropological Society Volume XLII for 1993, pp. 179-210.

Yelacic, David M.

2013 Feature Descriptions. In Defining the Middle Archaic at Spring Lake: Data Recovery and Analysis at 41HY160 for the Texas Rivers Center, Texas State University-San Marcos, Hays County, Texas, edited by Jon C. Lohse. Archaeological Studies Report No. 29, Center for Archaeological Studies, Texas State University-San Marcos.

Yelacic, David M., Gregory J. LaBudde, and Jon C. Lohse

2008a Cultural Resources Survey of Fairfield Lake State Park, Freestone County, Texas. Archaeological Studies Report No. 15, Center for Archaeological Studies, Texas State University-San Marcos.

Yelacic, David M., R. Zac Selden, and Jon C. Lohse

2008b Results of Archaeological Monitoring at the Fish Ponds, Texas State University-San Marcos, Hays County, Texas. Technical Report No. 33, Center for Archaeological Studies, Texas State University-San Marcos. 
